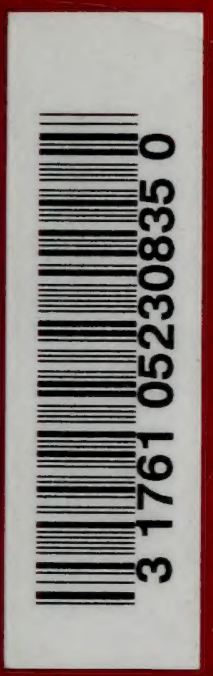




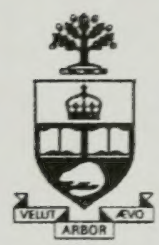

Presented to the

LIBRARY of the UNIVERSITY OF TORONTO by

PROFESSOR WILLIAM KEITH 


THE ILLUSTRATED POCKET LIBRARY OF PLAIN AND COLOURED BOOKS

THE ANALYSIS OF THE HUNTING FIELD 



\section{THE ANALYSIS}

OF

\section{THE HUN'TING FIELD}

BEING A SERIES OF SKETCHES OF THE PRINCIPAL CHARACTERS THAT COMPOSE ONE. THE WHOLE FORMING

A SLIGHT SOUVENIR OF

THE SEASON

$$
\text { I } 845-6
$$

WITH NUMEROUS ILLUSTRATIONS

BY H. ALKEN

A NEW EDITION

METHUEN \& CO.

LONDON I904 
NOTE

$T^{H I S}$ Issue is founded on the Original Edition, published by Rudolph Ackermann in the year 1846

LIBRAPY

DEC 71999 



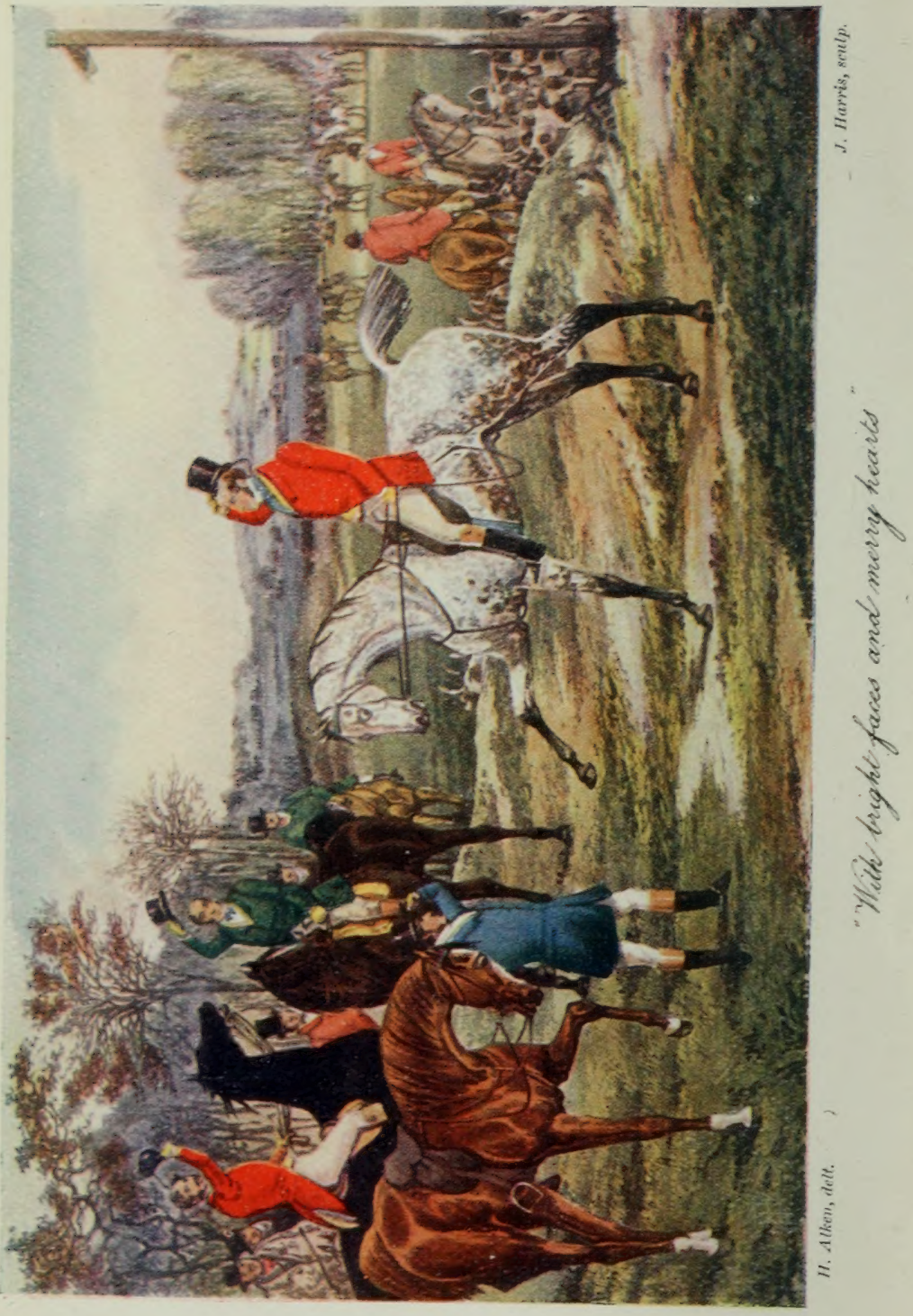




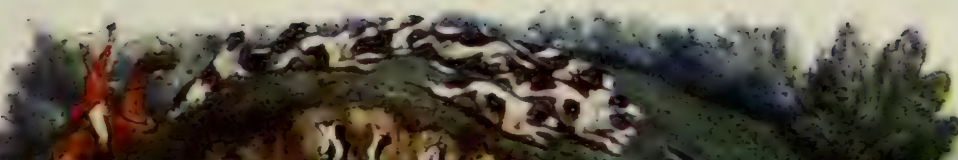

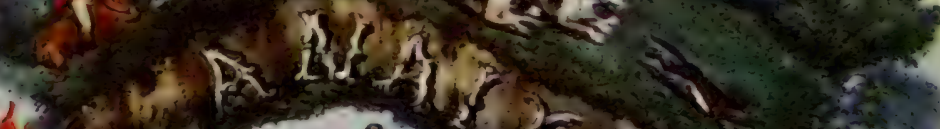

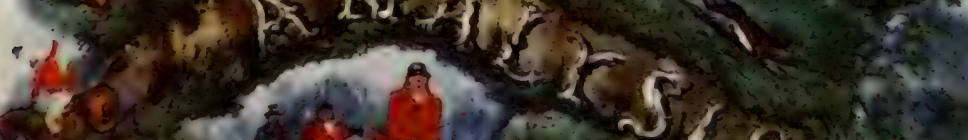

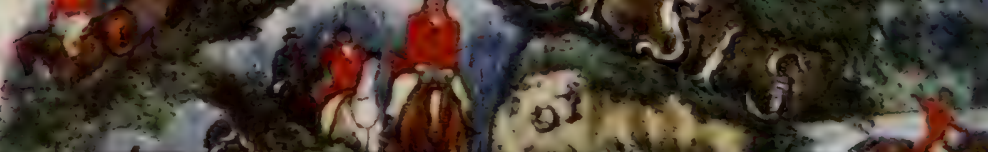

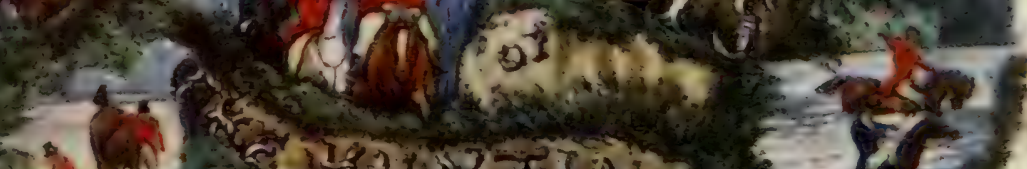

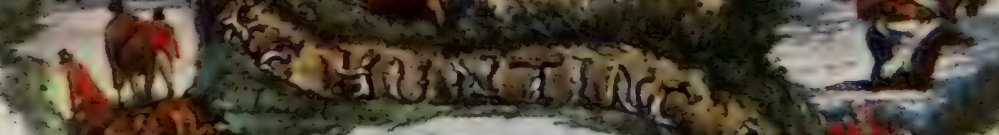
28uts

xists

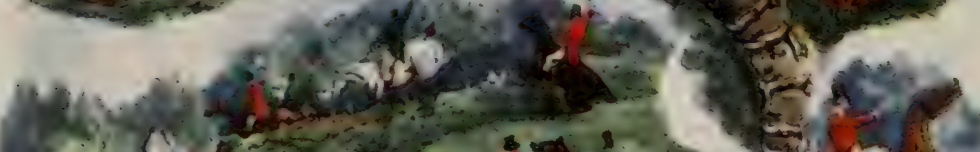
ang $-170-205$

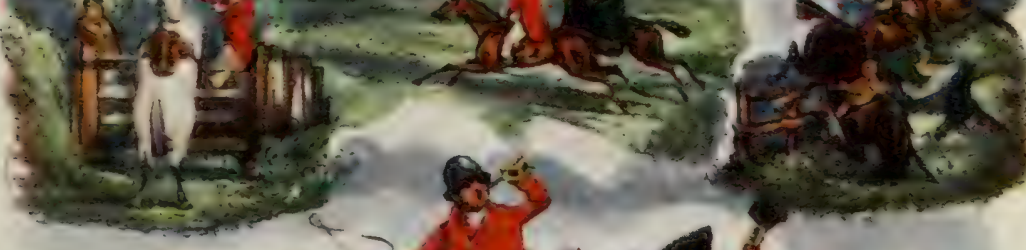

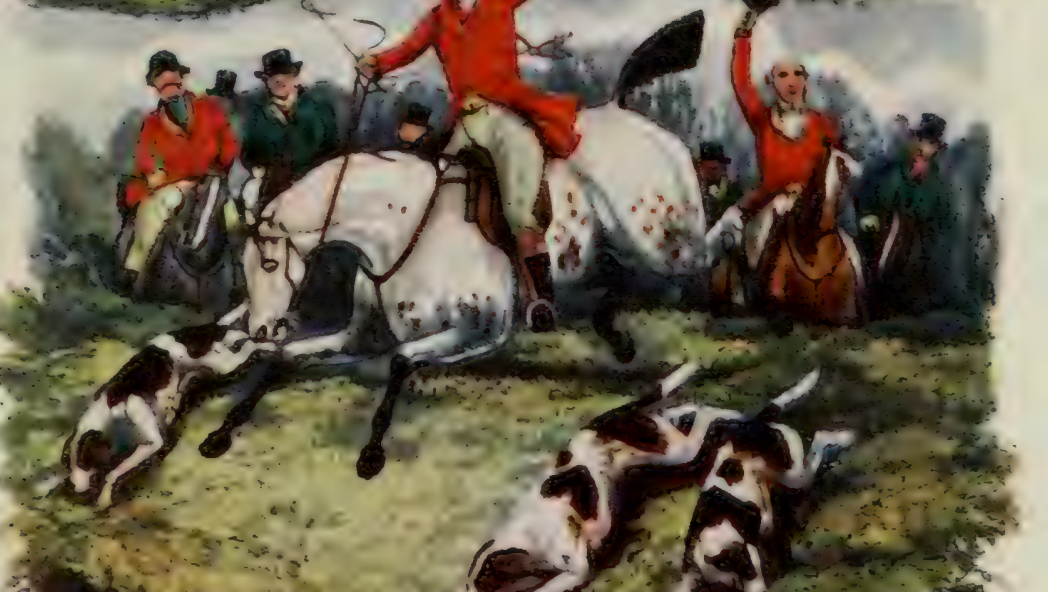

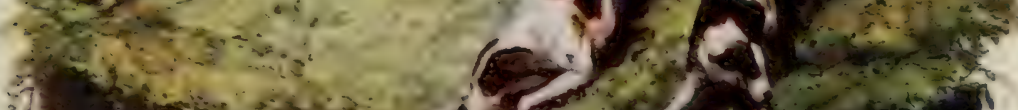

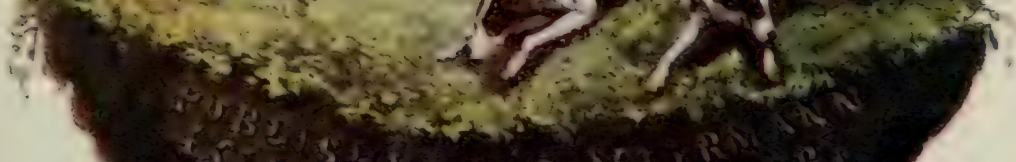
- The 



\section{P REF A C E}

THE following papers appeared in "Bell's Life in London," Sporting paper, during last season, and, independently of their reference to foxhunting generally, form a slight Souvenir of that extremely farourable winter - the best hunting one in the author's recollection; as such, he respectfully dedicates them to his brother sportsmen.

igi, Regent Street, London,

October, 1846. 



\section{P REF A C E}

THE Author of the following work believes it will be generally observed that the sporting mania has greatly increased of late years, though the followers of the chase have not increased in the same proportion as the patrons of the "turf," the "leash," and other money-mixing amusements. This perhaps may be attributed to an erroneous idea that hunting cannot be enjoyed at other than serious cost, while some few attempt to make "both ends meet" by horse-dealing, steeple-chasing, and hurdle-racing.

To correct the idea relative to expense, to repress the over-riding spirit engendered by steeple-chasing, and to encourage a fair and generous spirit of sporting enterprise and social intercourse, are the objects mainly aimed at in the following examination of the component parts of a hunting field.

The man with one horse will here be found as welcome as the man with ten. The man with ten will not be able to make a better fight than the man with one; while the mere tricky pretender is treated as such gentry generally are. In short, the volume is written with a view of upholding the great national 
sport of hunting in its purest, most legitimate form, and of decrying all attempts at money making, out of what ought to be sheer pleasure.

The work opens with a meet of foxhounds, for the purpose of introducing the characters as they generally arrive;-master and servants first, black coats next, reds after them, and so on; but in its progress the season is supposed to advance until the work ultimately forms a "souvenir" of that of $1845-6$, -one that all sportsmen will admit was eminently deserving of the compliment.

It was, perhaps, the best hunting season of modern times; and its lustre will be increased by the unfavourable one that followed.

I9I, Regent Street, I847. 


\section{O N T E N T S}

CHAP.

I. The Master-Month, October . . I

II. Adjouried Debate - the Master at Cottonwool's . . . . . I4

III. The MASTER-Continued . . . 2 I

IV. The Master-Concluded . . 27

V. The Huntsiman . • . 39

VI. The Huntsman-Contimed . • • 53

VII. The Whipper-IN • • • • 66

VIII. The Whipper-IN-Conchided. • • 8I

IX. The EARTh-Stopper • • • . 99

X. THE GroOM . • • • • II5

XI. THE GROON-Continued - . $~ I 29$

XII. THE GROOM-Concluded . • . 143

XIII. Peter Pigskin . • • • . 154

XIV, ThE FARMer • . . . . I68

XV. Elijah Bullwaist, the Blacksmith • IS5

XVI. The Squire • . . . . . 203

XVII. Lord Evergreex; With some Thoughts on Tuft Hunting . . 
CHAP.

IVIII. Captaix Shabbyhouride, the Steeile-

IAGE Chaser . $\quad$. 20.0239

Aix. Cartaix Shabbyhounde-Concluded. . 264

XX. Lady Foxhuxters-Sir Rasper Sirashgate and Miss Cottonwool • • $\quad 287$

XXI. Colonel Codshead; or, the Close of the Season . . . . 307 


\section{LIS'T OF PLA'TES}

Plate I. The Meet, (With bright faces and merry hearts.) . Illustrated Title-page

"2. Getting Away. (Let's take the lead.). . . . . To face page 8I

" 3. Full Cry. (Let's keep the lead.) . . . . . . " $\quad$ I54

" 4. THE Check. (What the devil do you do here.) . , 203

" 5. THE LEAP. (That will shut out many, and make the thing select.) . . . . , , 239

" 6. Whoo-Hoo-oop. (A chosen few alone the death survey.) $\quad$. $\quad, \quad 287$ 



\section{THE ANALYSIS OF \\ THE HUNTING FIELD}

\section{CHAPTER I}

THE MASTER-MONTH, OCTOBER

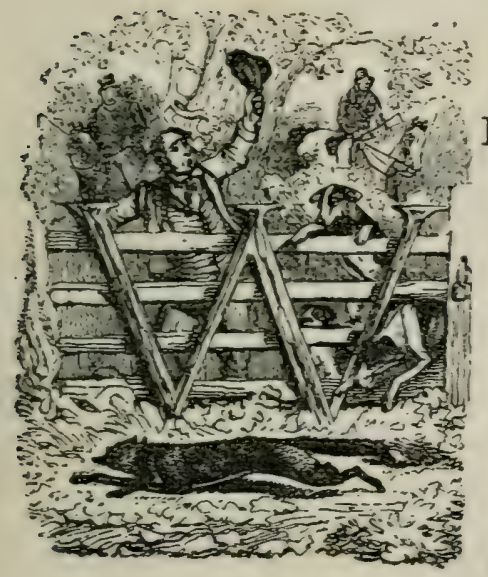

ITH a very slight touch of summer, ${ }^{1}$ here we are again close upon hunting-nay, in some parts it has commenced already. In London the "sear and yellow leaf" reminds us of the old "red rag." What can compensate for the beauties of departing summer, but the glories of the chase? Confound it, we believe we'd almost compound for the absence of summer altogether, if we could but enlarge the operations of the pack. Well, however, "Here we are again!" as Mr. Merryman exclaims, as he bounds into the circle. "Here we are again!" Another month, and the season will be in its pride. Let us indulge the pleasures of anticipation by giving our mind's-eye a canter round the hunting field.

${ }^{1}$ The summer of I 445 was singularly wet and unseasonable; for further particulars, see Preface. 
First comes the Master-punctual as Masters should be. His clever grey hack has scarce turned a hair, though he has come no end of distance within the hour, while the rider as he enters the field drops the reins, and, raising his hat, wipes the slight perspiration from his brow with a stout bandana, showing the thinning hair of his crown, and the slightly shot grey of forty, or five-and-forty years. But look what health is on his brow. Fine clear complexion, light bright'eye, full lip, white teeth, steady unshaken hand of early hours, strong exercise, and sobriety. We have seen many older men at thirty.

Our Master looks the sportsman all over : neat, we may almost say smart; but not the smartness that is afraid of dirt. No dandified satin or French polish flimsy finery is here; all is stout, warm, and weatherdefying. The good heavy hat (caps for gentlemen we abhor) would resist a deluge, or one of 1845 summer's rains, the round-cut single-breasted red coat, confined by one button, across the step-collared toilanette striped waistcoat, is made of strong doublemilled cloth; the roomy breeches are of broadish striped cord, not exactly white, but what will scour to white; and the well put on boots are made of that comfortable-looking leather that tells to the eye how soft they sit to the wearer's foot. But mark; they are not jacks-hang sour jacks, say we! ditto your Napoleons ; ditto your cab-head leather fisherman's, with mouths gaping like joung rooks, and which seem capable of carrying half the wearer's wardrobe, along with his legs. Give us the good old top-the top that neither degenerates into affectation by its shallowness nor its depth; the top that looks as if it cares not for bullfinch or briar, and whose soles are of sufficient strength to command the respect of the kickable portion of the community. For any one, save perhaps our late respected friend the living skeleton, there is no costume equal to boots and 


\section{THE MASTER-MONTH, OCTOBER}

breeches-boots and breeches well made, and well put on, indispensable accompaniments for the welllooking of both. We could write a chapter on boots, but as we purpose passing the field in review, we will glance at their various characters as the wearers come before us. Spurs, too, are an eloquent subject for dissertation. If any one would collect the hats, gloves, whips, boots, and spurs of a field, placing

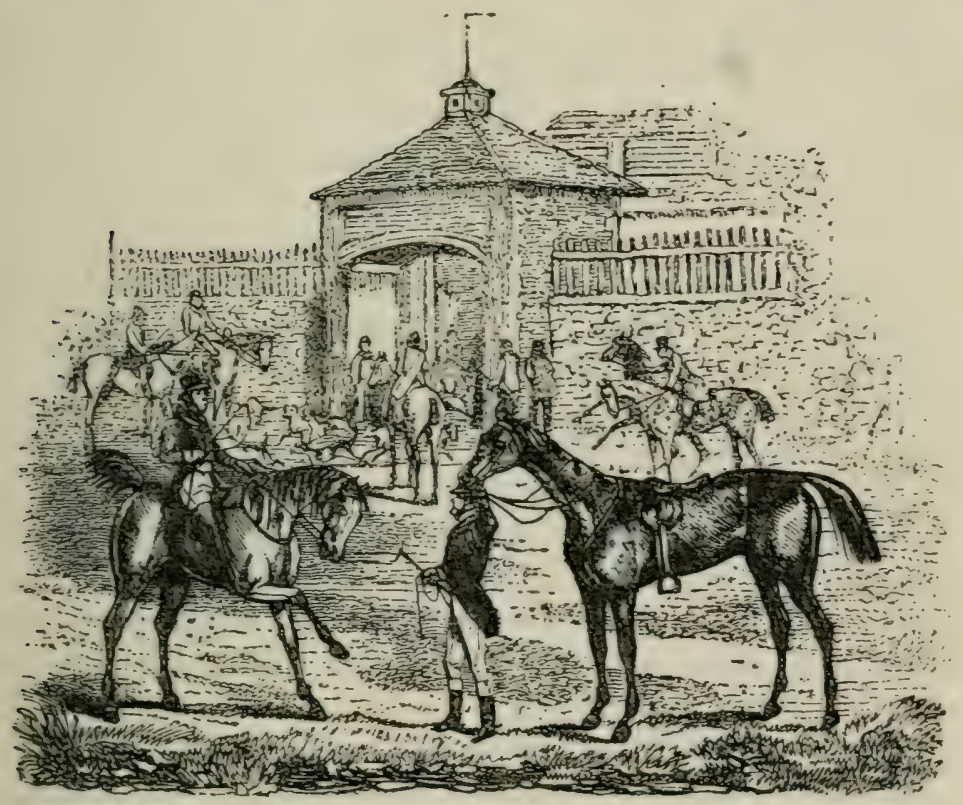

each set by themselves, we would undertake to appropriate them to the station in life of the respective parties. These, too, however, for the present, we shall "pass," as the auctioneers say, simply observing that our Master's gloves are doeskin, his whip a lapped whalebone one, with a hammer head, his persuaders of the Jersey pattern, with silver studs and buckles. The well polished strap-ends come well over the buckles, and the boots altogether 
wear a sort of air that says no common mud shall stick to us.

A Master of Hounds is one of the most difficult characters in life to fill; hence it is not surprising that there are but two sorts-the best fellows under the sun-and the nastiest brutes going. Fortunately for society, the "nastiest brutes" going, are so select and so self-convicting a set as not to require much description from us; they are generally waffling, fretting, fussing, fuming, vapouring bodies, who soon make way for one of the "best fellows under the sun." Now the best fellows under the sun, like the "best horse going," are a numerous breed, but, as applied to masters of hounds, they must, to a certain extent, have the same qualities, though they may have very different ways of showing them. First and foremost they must be keen. About this there must be "no mistake," as the Duke of Wellington would say. It would be not a bit more absurd for a man to punish himself by keeping a yacht, who hates sailing and the sight of the sea, than it is for a man to keep a pack of foxhounds who has no ardent predilection for the chase. A qualified liking will not do for a "best fellow under the sun." He must be heart and soul in the sport-a real out-and-outer. Keenness covers a multitude of sins.

In addition to the sine qua non of keenness, he should possess a host of other qualities. He should have the boldness of a lion, the cunning of a fox, the shrewdness of an exciseman, the calculation of a general, the decision of a judge, the purse of Squire Plutus, the regularity of a railway, the punctuality of a time-piece, the liberality of a sailor, the patience of Job, the tact of an M.P., the wiliness of a diplomatist, the politeness of a lord, the strength of an Hercules, the thirst of a Bacchus, the appetite of a Dando, the digestion of an ostrich, the coolness of a crocodile, the fire-enduring powers of a salamander or of Mons. 
Chabot, the Fire King, with a slight touch of the eloquence of Cicero, and temper as even as the lines in a copy-book. Lor bless us, what a combination of qualities! John Austin, the peripatetic showman's happy united family in the body of a foxhunter!

Noney! money! money! like Mr. Wilberforce's reiterated cry of Sugar! sugar! sugar! is, however, perhaps, the most important thing after keenness and temper. City people, perhaps, would put money first, but that shows they know nothing about foxhunting. A real keen-un will generally get a country, even though he has a soldier's thigh, before John Plutus, who has only his money pots to recommend him. Money, however, there must be, either from the Master or the field; happy, therefore, is the country possessing a Master in the enjoyment of the qualifications we have dotted down, and who is willing and able to pay his "own shot"; dearly should they prize him, for were they to lose him we really don't know where to recommend them another.

Having sent for our maid of all work to try the foregoing upon her, we observed that she neither smiled nor even relaxed a muscle of her rather pretty countenance, till we repeated the word "sugar," and, when we had concluded, she observed, with her usual candid diffidence, that she did not understand what all these qualities had to do with the "red coats," as she calls them, conceiving, we rather suspect, that foxhunters are a sort of off-shoots of soldiers.

As we may have other readers in a similar predicament to Susannah, we will be our own "Boswell," and treat them to a running commentary on the obscure portions of our text. This we may do in a rambling sort of way, without reference to the order in which they now stand.

A Member of Parliament is generally supposed to have a ticklish up-hill sort of game to play, but it is nothing compared to that of a Master of Foxhounds. 
The Member has merely to bamboozle people once in six or seven years out of something that really is hardly worth giving or receiving, and to change his coat at short notice, but the Master of the Hounds has to keep his soft solder pot boiling all the year round, healing real or imaginary wounds, trying to make farmers believe something very much like "black being white," coaxing them into a credence that it benefits wheat and sown grass to ride over them, that foxes never touch lambs, and abhor poultry, that it benefits hedges for horses to dance hornpipes upon them, with many other similar and singularly curious articles of belief.

So much for the M.P. quality.

Time! which assuredly has begun to go quicker since railways were introduced, has even carried the gastronomic feats of "Dando," into the oblivion of all forgetfulness; yet let it not be said-Dando, though dead, yet lives in the recollection of oyster-shop keepers and licensed wittlers-Dando, ${ }^{1}$ who could eat a peck of oysters, and pick his teeth with a shoulder of mutton bone for luncheon-Dando, the nimble, plausible, dexterous Dando, who, with all the luggage aboard, could outstrip the most heron-gutted chophouse waiter, or the swiftest and best winded of the great "unboiled"-Dando can never die! Die he may, in the common every day dolly-mop world, but die he never can in the recollection of those whom he honoured with his large, though somewhat expensive patronage.

And how do we connect the feats of Dando with

1 Dando, we may state for the benefit of the juvenile, was a wandering sort of cormorant, much addicted to oysters, but whose means being in no way proportionate to his appetite, he used to be under the necessity of "bolting" after having "bolted" as many oysters as he could hold. He used to afford "fine runs" to the police, and we believe it was in contemplation at one time to engage him for the purpose of being hunted by the Queen's stag hounds. 


\section{THE MASTER-MONTH, OCTOBER}

the necessary qualifications for a Master of Foxhounds? Why, thus-Dando was a great "feeder," and so should a Master. Next to drawing a gentleman's covers in a morning, drawing the ladies' covers in an evening is of the last importance.

And here let us request our friend the printer to have the kindness to print the word "cover" as we have written it. We are aware that modern fashion has tacked a " $t$ " to the end, but Peter Beckford, who is quite authority enough for us, wrote it as we have done. Moreover, in this instance, adding a " $t$ " would spoil the point of the sentence.

Hark, back to dinner, and Dando!

Hunting and hospitality are almost synonymous, and the man who hunts a country must calculate on a good deal of knife-and-fork work. Dining out much is hard work-dreadful where a man is "cock" guest every time. Still a Master must undergo it, or the ladies won't reckon him "a nice man." If the dress uniform of the hunt is scarlet, or yellow, or orange vermillion, sky-blue, pea-green, or any other outlandish colour, "the Master" must wear it, or Mrs. Cottonwool will think herself slighted. Then, with an ostrichfeathered red and gold-spangled turban nodding over a well-oiled front, with cork-screw ringlets at the sides, Mrs. Cottonwool after having waited past all patience for the much-wished-for, but non-arriving guest, is at length led from the furniture-uncovered drawing-room by our "model of a sportsman," in all the lady-like trepidation of unaccustomed party-making. All the Bore'ems and Snore'ems, Tom Browns, and Jack Smiths of the hunt, figged out like their chief, follow in long-drawn file, whipped in to, by Cottonwool, similarly attired.

The Miss Cottonwools will be scattered down the table just as market gardeners scatter their flowersfirst a rose, then a lily, then another rose, then another lily-first a foxhunter, then a lump of Cotton- 
wool, then another foxhunter, then another lump of Cottonwool, apparently "quite promiscuous," as the servants say, but in reality with a good deal of hen Cottonwool "management." Our Cottonwools, however, are not lumpy; on the contrary, fine, full-grown, full-limbed, ripe, luscious-looking, fair-haired girls, radiant with all the accomplishments of ogling, worstedworking, dancing, and flirting. But we are leaving our Naster, soup-ladle in hand, pinned on the right of ringlets, who sits telegraphing her daughters into their places, the order of march having been somewhat disconcerted by the stupidity of Sam Bore'em not knowing that Robertina has been setting her cap at him for many months, and who has consequently endangered Juliana's being stuck between papa and old Mr. Pigskin, the family stop-gap, by taking out Henrietta instead of his intended, or rather, the lady who intends him. At length they all get settled into their places, with no other derangement than two of the guests getting rush-bottomed chairs which were meant for the daughters, and a room which would accommodate eight comfortably, or ten on a pinch, is now made to hold eighteen. Of course the curtains are all drawn, the shutters are shut, and there is a rousing fire. Oh, Hookey Walker! Hookey Walker! to what little purpose you wrote the "Original."

From eighteen take "one," says the Master in his own mind, and seventeen remain. Seventeen glasses of wine at dinner! Awful! Awful at any time, but doubly so when supplied by a bumper-filling clown, who will shut out the skylight, or give the objector the balance over his hand or up his sleeve. Pigskin is the only man our Master dare compound with by clubbing with another; but then comes the question who is to be the other? and also the consideration whether it is not better to go the "entire animal," and drink with the whole-Robertina, Juliana, Henrietta, and all. 
Drinking, however, is only half his work. That is a duty he owes his host. He must eat out of compliment to the lady. Some ladies, too, are so unconscionable. The more a man eats the more they require him to eat. "Oh, you must let me send you some of this. Oh, you must take a little of that. Oh, yow must try some of t'other. You really eat nothing. Dinner eater! I never saw such a dinner eater! Dinner's wasted on you, however."

Kind hostess, let us say a word on behalf of our poor Master. Give what you give freely and heartily, but give your guests credit for knowing their stomachs better than you do.

What with good dinners, middling dinners, and bad dinners-what with good wine, middling wine, and bad wine-what with the room always at fever heat, have we not made out our case that a Master requires the propensities of Bacchus, with the appetite of a Dando, the digestion of an ostrich, and the firedefying properties of a salamander, or of Monsieur Chabot, the Fire King? We think we have, even to the satisfaction of Susannah aforesaid.

Dining out is almost indispensable for a Master of Foxhounds, for the English never fancy a friendship fairly cemented until it has been riveted on the altar of the mahogany. It is convenient too, in some cases, such as hunting a distant part of the country; besides, it makes an agreeable change, especially when the party is not composed entirely of the same people as have been "hob-a-nobbing" it at "the club" for weeks together. This is one of the mistakes nonhunting people make. They fancy that none but foxhunters will do to meet foxhunters. Our friend Cottonwool's three fair, blooming, buxom daughters make an agreeable variety; but if "Wool" had not had them, he would have filled their places with three other "red or orange-vermillion coats," if, indeed, he had the "Naster" at all, which is more 
than problematical, seeing he never had his predecessor, and always abused the hounds and all belonging to them, until his daughters were invited to the hunt ball, and he saw Henrietta in the grasp of Sir Rasper Smashgate, a hard-riding baronet, going the rounds of a waltz with all the liveliness of a waggon-wheel. "Wool" then began to mumble to himself something about "more unlikely things," "fine estate," and Mrs. Wool and he jumped to a conclusion that Wool ought to be a "sleeping partner" in the hunt, and have the Master to Fleecy Hall. The thing suited Wool's purpose, and it suits our Master's; at least it would have done if they had not nearly roasted him alive. And here let us have a word " $\dot{a}$ la Walker" to Wool and all the sleeping partner tribe. Nay, some managing partners even may be benefited by our truisms, if they would but remember them. Have a good fire in each guest's bedroom when they arrive. People out of gigs, off coaches, out of railway trains are apt to be chilly and cold. There let them warm themselres-but remember, oh remember, that a lot of people put into one room, with lamps, candles, wittles, and waiters, will very soon cook up a devil of an atmosphere. Shutting the shutters, drawing the blinds, closing the curtains, is all very right and meritorious when you are alone; but with such a kettle of fish as we have got at "Wool's" you should take every precaution to have the room cool at starting, and to try to keep it so. A little wood fire looks lively, and soon dies out; but if it has the impudence to live, a pan of wet sand soon knocks the vital spark out of it.

But we have it not in our hearts to keep our poor Master in this atmosphere any longer. Let us suppose the agony of dinner past. Let us suppose that all has gone on smoothly and well-no soup dribbled down any one's back, no poisonous lamp expired, no tipsy cake alighted on any one's head, no squashed 
blanc-mange, no pyramid of jelly toppling to its fall -nothing gone wrong, except the white jug of hot water at the side-board end upset on the third plunging of the forks and spoons, making a map of Italy on the un-Turkey-carpeted part of the floor. The Miss Wools have each plied a merry tongue, though, between ourselves, it is not exactly the way to a foxhunter's heart to interrupt him during his dinner; but of that more anon. Mrs. Wool has given the silent, significant hint-a hint more potent than the strongest lunged sergeant ever bellowed on parade-gloves, flowers, bags, handkerchiefs, fans, have been gathered together, or brought up from their respective collieries below, and our Master gladly rushes to open the door to let the well-bustled party pass.

Each man stands, and puffs and blows like a stranded grampus.

It is now Wool's turn to take our Master through his hands. One would think that Wool was Monsieur Chabot in disguise, for the first thing he says as he clutches his glass and decanter, preparatory to moving his quarters to the top of the table is, "Would you like a few more coals, Mr. Rattlecover?" We need not add that Mr. Rattlecover declines, observing that, with Mr. Cottonwool's permission, he will change his seat away from the fire, when, like many wise men who know everything after they are told, old Wool observes that he does think the room rather warm. This brilliant discovery being universally confirmed, they forthwith proceed to the other extreme, and opening all the doors and windows, just give old Æolus the full swing of the apartment.

Something like a liveable atmosphere is at length procured, and the business of the evening is begun 
by the "sleeping partner" asking some absurd questions about hunting.

Cottonwool does this from the same mistaken notion that would have induced him to ask none but foxhunters to meet a Master of Foxhounds, viz. an idea that foxhunters can only talk about foxhunting. Mistaken man! Nine-tenths of them would rather talk about anything else. Annoying, however, as it is to hear a man talking nonsense for our accommodation, calling a pack of hounds a set of dogs, a hound's stern a bushy tail, giving tongue, barking, and so on, a Master must not break out and bid him "hold his tongue for a $\mathrm{d}-\mathrm{d}$ fool," as a sailor would. No, he must humour him- "sugar his milk," as a huntsman would say; for the best hounds in the world, with the "best fellow under the sun" at the head of them, are useless without foxes, and fox or no fox is the caprice of such creatures as Cottonwool. Some Cottonwools are apt to "keep the word of promise to the ear and break it to the hope," giving their keepers orders perhaps not to shoot foxes, but at the same time not to let a vixen lie up on the estate. There are many ways of preserving foxes - at all events of salving a not troublesomely fastidious conscience. If our "best fellow under the sun " suspects anything like foul play, he will lead old Wool unto the ice, get him to talk big about hunting, the pleasures of the morning, the delights of a find, the certainty of sport, the abundance of foxes-our Master slyly exclaiming to old Pigskin or any one furthest off, so that every one must hear, "Ah, Mr. Pigskin, I wish all people were like our worthy host Mr. Cottonwool! There would be no lack of foxes-no fear of sport then." He may then observe, almost to "Wool" himself, "I'm sure all here will bear me out in saying that I always hold our excellent friend Mr. Cottonwool up as a perfect specimen of what an English gentleman ought to be." Now, that is good, wholesome, un- 
adulterated flattery-all Wool's own too, and the odds are that thinking he has not committed himself, he will retract the qualifying order about the vixens, and show himself at the next cattle-show as a perfect specimen of what an English gentleman ought to be. More people are flattered into virtue than bullied out of vice.

Toast drinking is almost exploded, but if ever it is tolerated it will surely be allowed to wash down such a pat of butter as Cottonwool has received. The way to accomplish this, of course is, for Wool to propose the Master's health-long life to him-with such other novelties as a podgey old gentleman, unaccustomed to public speaking, can accomplish; and the Master (who we premised must have a touch of Cicero), may just turn the remains of the drippingpan of flattery over Wool's head and shoulders any way he likes. A glutton in flattery looks more to quantity than quality.

With that performance we will let the chapter's curtain drop.

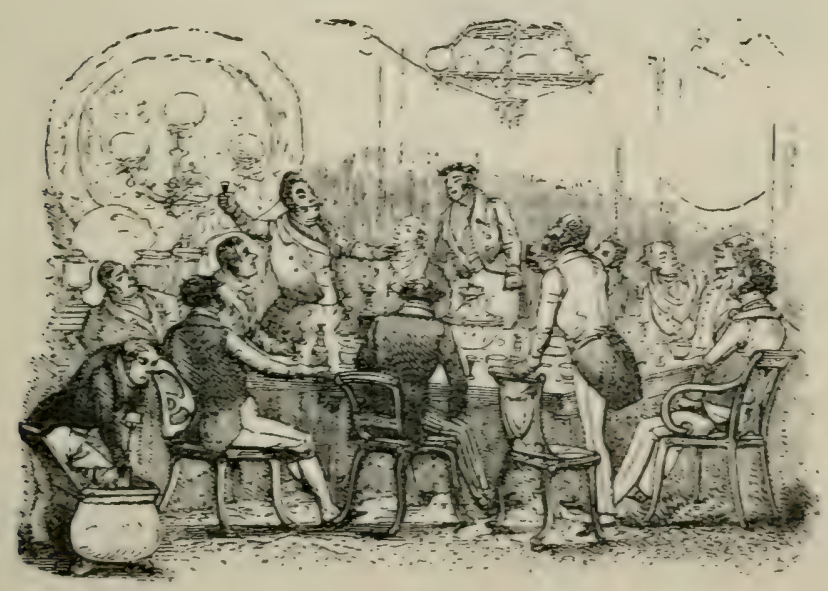




\section{CHAPTER II}

\section{ADJOURNED DEBATE-THE MASTER AT COTTONWOOL'S}

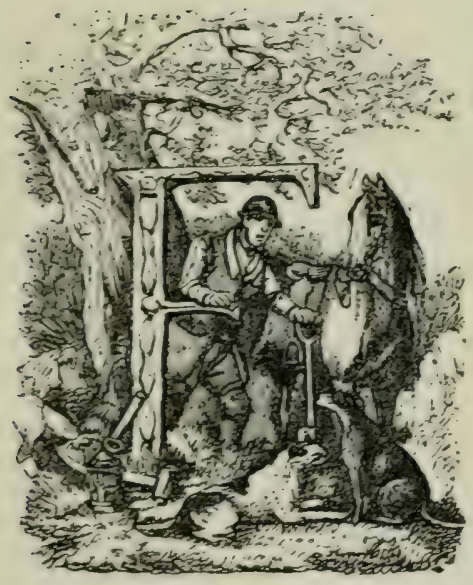

OR brevity's sake, we will condense the proceedings of the evening into the potted-game sort of style some ingenious gentlemen about the House of Commons adopt towards the windy proceedings therein, for the accommodation of political club lobbies.

We don't print ours in columns, because it is not convenient. We hope the omission will not be considered a breach of privilege.

EIGHT O'CLOCK.-Cottonwool returns thanks for the honour they have done him in drinking his health, etc. ; drinks all theirs; port and claret ordered.-Observations. Party quite sober. Pigskin asleep.

Half-Past Eight.-Host gives "Success to foxhunting." Bumper toast. Pigskin accused of taking a back hand; Pig replies; division; I 3 to I, Pigskin voting; ordered, "song or salt and water;" song pre- 
ferred; "We won't go home till morning ;" more port -two bottles this time.-Observations. Party merry; Pigskin half-cocked; Sam Bore'em nodding; host speaking thick.

NINE O'ClOCK._- "Chair! chair!" Host proposes "Master's health" again, assuring him that Fleecy Hall covers shall never be drawn blank; amendment by Pigskin, "That the toast be drunk with three times three;" carried nem. con.; drunk; moved by Tom Lax, and "one cheer more" given; port and claret -2 and I.-Observations. Party noisy; room hot; gentlemen's waistcoats loose.

Quarter-Past Nine. - Master returns thanks again; proposes a bumper toast; no heel-taps; "The Ladies!" three times three, and one, etc.Observations. Very merry; Pigskin three parts drunk; Master half-cocked; Sam Bore'em asleep.

Let us now suppose it half-past nine, and that Mrs. Cottonwool and daughters, having got themselves cooled, have lit their "Brecknell and Turners'," shaken out their feathers, and taken positions best calculated for capturing their respective prey as they enter the drawing-room. And here we may pay the "deferred" annuity of information we promised our fair friends, as they left the dining-room. It is this :A man is much easier come over when half-mellow, than when half-fed. We observed, with sorrow, not altogether unmingled with anger, that you pestered your next door neighbours with your pleasantries when they had their mouths full. Nay, we caught Robertina interrupting hers in the middle of a glass of champagne! All this is very wrong. Our Master will tell you that he never speaks to his hounds so long as they will hunt. So you, on your parts, should never speak to a foxhunter so long as he will feed. It is all very well for you ladies who dine at luncheon time to trifle with the golden 
moments of dinner, but it is serious work with a half-famished sportsman, especially with the pace nervous servants of all work go on these occasions. Besiege your men at tea. That is your time. You may offer them a cup of coffee, but you can't ask them to take wine. Of course you have a piano in the room. Music is a great assistance in love-making. Its noise keeps whispers where they should be, and though you are all very jealous of the time lost in playing, yet if you have a fine arm and tolerable execution, we don't know but you may be doing more business with your fingers than you would with your tongue and eyes. At all events, sisters can arrange to relieve each other, on the "now thou, now me, now both together," principle. "Music," some amiable gentleman writes, "has charms to soothe the savage breast." God forbid that it should not have the same influence upon sportsmen! And here we may observe that, though foxhunters may not be men of many words, what they do say is generally to the purpose. "Isn't this," as Beckford would say, "far better than the eternal babbling of unsteady puppies? Puppies who merely babble to lead the ladies astray, to

'Love again, and be again undone."

There's Henrietta's friend Smashgate, for instance - we beg pardon, Sir Rasper Smashgate-we will stake our literary reputation that a squeeze, a good squeeze from the Smashgate hand at bed-time, would mean more than an hour and a half's blather from young Fribbleton Brown, about roses and lilies, and love in a cottage, hearts, darts, Cupids, and the whole mint of matrimonial small coin.

We would almost excuse Henrietta if she presented herself to mamma as "Lady Smashgate," on reaching the landing. "What, has he offered to you?" old Turban would exclaim. "No, mar, but he squeezed 
my hand as he gave me the candle." "Silly girl," Mrs. Cottonwool would reply, in a pet-not knowing the nature of the animal- "many squeezes go to an offer." Were we a girl, however, matrimonially inclined-which they all are, unless bespoke-we would rather have a squeeze of the hand from Smashgate than a black and white offer from Fribbleton Brown. Spite of what old mother Cottonwool says, we will lay "copious odds" - as old Crockey used to say, that she would give old Caudle Cottonwool a hint that things were "going on right," and take all the credit to herself too. Cruel Smashgate, however, has not come.

While nibbing our pen, we have been casting about to see if we could recollect any instance, among our numerous acquaintance, of a bad foxhunter husband, and we are happy to say we have drawn the cover blank. We have, to be sure, fallen in with fellows in red coats, who have been anything but what they ought, but we can conscientiously say that we have never known any man worthy the name of a sportsman, who was not a good fellow. Indeed, were we a young lady, we would pick a foxhunter for preference. Their coats may not be quite so glittering as the laced jacket of a soldier, nor may they be quite such good hands at dancing the polka, but, for the real steady comfort and enjoyment of life they beat them by chalks. Besides, war's alarms are trying, soldiers are very apt to shut up shop when they get married; and, if they don't, why even a child tires of looking at the same dressed doll.

A pleasant poet, whose name we forget-indeed we are not quite sure that we ever had the pleasure of his personal acquaintance-wrote something about something, and 
The compliment, we believe, was turned for the ladies, but we are going to "diwide it," as the dentist said, when he threw the bucket of dirty water over the blind fiddlers.

We should say, that a foxhunter and his wife can not only make to-morrow cheerful as to-day, but they can make winter as pleasant as summer-that is to say, if they go the right way to work.

Even in sweethearting a foxhunter is worth a dozen such fellows as Fribbleton Brown-fellows who hang about a drawing-room all the morning, fumbling in women's workbags, stealing their thimbles, and stopping their worsted work. Women like to have men "in tow," no doubt, but they don't like to have fellows lying "at them" all day, like terriers at foxearths. The foxhunter goes out to "fresh fields and pastures new," hears all the news, the fun, the nonsense, the gossip of the world. His mind's enlarged, his spirits raised, his body refreshed, and he comes back full of life and animation. If he has had a good run, and been carried to his liking, his harvestmoon heart loves all the world. He'll do anything short of accepting a bill of exchange. Our esteemed friend, the author of the "Pleasures of Hope," albeit no sportsman, or at least not a master of hounds, shadowed out the feelings of a sportsman, and of a sportsman's lady-love, when he sung

"W Who that would ask a heart to dulness wed, The waveless calm, the slumber of the dead? No; the wild bliss of nature needs alloy! And falls and tumbles fan the fire of joy!"

We are not quite sure that "falls and tumbles" are the words he used; perhaps not. They savour of tautology, but again that looks more like a non-sportsman, as Campbell was. Be that as it may, they suit our purpose. There is no doubt, however, that the roughings, and scramblings, and wettings and rollings, 


\section{THE MASTER AT COTTONWOOL'S}

and muddings of the morning, all tend to make a man enjoy the comforts of home and the pleasure of female society in the evening :-

"Domus et placens uxor."

"Thy home, and in the cup of life,

That honey-drop, thy pleasing wife,"

as those few Latin words have been skilfully rendered by some talented linguist, with the skill of our friend, Bob Chalkup, the milkman, who can make a quart of milk out of a pint, but to make the foregoing fine jingle of words run right for the foxhunter, the "placens uxor" should always have breakfast ready in good time, and plenty of lambs' wool and fleecy hosiery before the fire, against her swain comes home. Confound it, there are very few of those sort of "uxors" now-a-days. Old Mrs. Pigskin is the only one we know of, but she belongs to a generation far removed in the distance. She can't work pheasants in floss silk! Some old sour grapers object to foxhunters, because they sometimes take a nap after dinner. Suppose they do, what then? They most likely have said their say, and surely it's far better for a man to go to sleep than to talk nonsense, or say the same thing over and over again. Take our advice, fair ladies. If it should ever be your luck to have to choose between a foxhunter and a fiddlerwhich latter comprises all people who are not foxhunters - choose the foxhunter. Not one of your pretty fellows, who come home clean and unspecked by luncheon time, but a regular sport-loving cock, who would rather lose his dinner than the end of a run. Don't mind what spiteful old maids say about their habits and propensities. If you wait till you get a man whom all the world will praise, you'll remain single to the end of the chapter.

The young lady of forty's reply, that a bad husband was a deal better than none, was a very sensible 
observation, though totally inapplicable to foxhunters.

But we are writing a chapter for chaperones rather than an essay on a "Master of Hounds." Farewell fair Miss Cottonwools; ere spring returns, may we read your names in the list of-you know what.

Good morning, Mrs. Cottonwool, and thanks for your hospitality. Good morning, Mr. Cottonwool, and thanks to you also.

Perhaps, however, having got so wide of the mark, we had better let the curtain down again, and resume "The Master" with a fresh chapter.

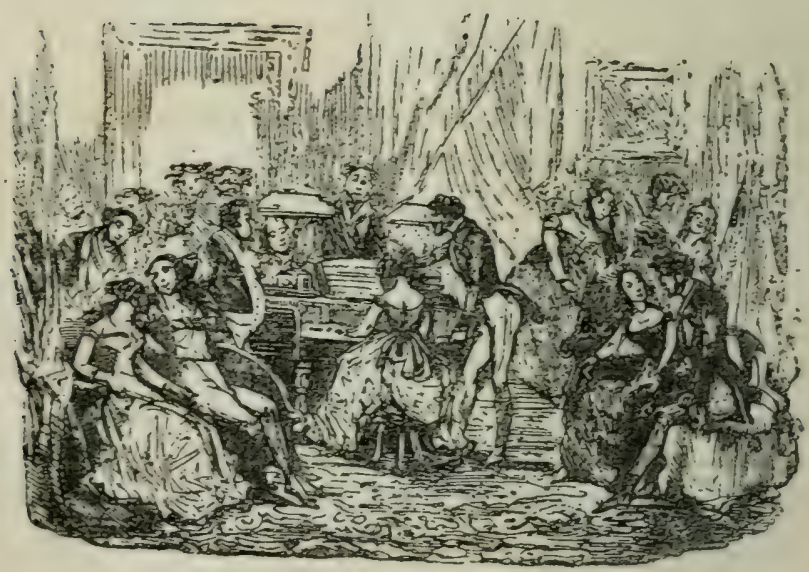




\section{CHAPTER III}

THE MASTER-continued

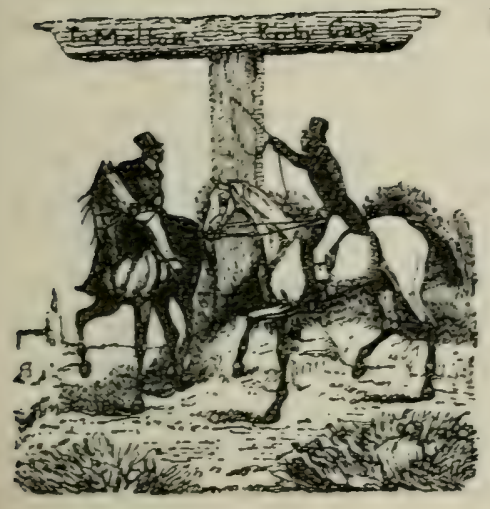

HE great Masters of antiquity, if we may so call them - Meynell, Beckford, Corbet, Lee Anthone, John Warde, Ralph Lambton, and so on-have been described as paragons of politeness as well as models of keenness. IVe doubt not they were, but we have as good gentlemen now-a-days, though the Grandison style is somewhat relaxed. The fact is, a man won't do for a Master of Hounds unless he is a gentleman. Wealth, birth, keenness, all combined, won't do unless he has that indescribable quality which may be best defined as a sincere desire to please, with a nervous dread of saying or doing anything that may hurt the feelings of another. Some men may go blundering and bullying on to be sure, by mere dint of purse, but it is a weary up-hill game, generally wearing them out at last, as it has worn out their followers.

We cannot help thinking that one of the mistakes of the day is that of making too much of a business of hunting. Hence we have nervous, irritable Masters, who are a nuisance to themselves and to 
every one they come thwart of. If a shooter was to make himself as unhappy about a bad day's sport as some foxhunters do, what a booby we should think him. "Better luck next time," is a fine consoling axiom, cheering alike to the foxhunter, the gunner, and the fisherman. Foxhunting is but a species of game, and whether a fox is killed, or a fox is lost, or a fox is mobbed, or a fox is earthed, makes no difference in the balance at the banker's-that converging point to which so many anxious earthly hopes turn.

Gentlemen, when they begin to do a thing, are very apt to do too much. They think if they take the Mastership of hounds that they must slave and toil like servants. Then we have a lot of babblement about "science," "condition," "generative economy," ".Ethiop's mineral," and we don't know what. Can science make a scent? "Kennel management," and all that sort of thing, is very necessary; but experience proves that a man may be a first-rate sportsman without troubling himself about minutiæ. Mr. Masters, if we mistake not, was no great kennelman, and we should like to have a look at any one with the boldness to deny his prowess in the field. The best gentleman-huntsman of the present day never feeds his hounds. We have even known paid huntsmen who never saw their's except in the hunting field.

The well bred hound-the well bred sporting dog of any sort-will always leave the man who feeds it for the man who shows it sport.

All economists, political ones and all, agree in the inexpediency of keeping a dog and barking one'sself; neither is it of any use a Master keeping servants and doing their work. The more trouble a man takes the more anxious he gets, and the more he expects; hence a great deal of that nervous irritability in the hunting field which is almost its only 
bane. Take it easy! Take it easy! "Better luck next time," say we.

To suppose that a man can be Master of a pack of hounds, and not feel differently when things go on smoothly and well to what he does when they all go crooked and wrong, is either to suppose that he is ignorant of what he professes to direct, or has feelings and passions different from other people. It is the mode of conducting himself under the circumstances, the language made use of, the manner, time, and style of the reproof that constitutes the difference between the "best fellow under the sun," and the "nastiest brute going."

The old Masters, if history is to be credited, indulged in the innuendo, or suaviter in modo style of rebuke rather than in the " $\mathrm{d}-\mathrm{n}$ your eyes" fortiter in re one. Thus Mr. Meynell, in reply to a persecuting over-rider, who would argue that he was right, would bow and smilingly say, "You may be perfectly right, sir, and I quite wrong, but there is gross ignorance on one side or the other." Even this sort of rebuke he did not care to repeat, generally the telling the man a second time that he was incorrigible, and it was no use admonishing him. Notwithstanding all his politeness, however, we are told that Mr. Meynell's indignation in the field was sometimes excessive, frequently expressed by looks, sometimes by deputies, but still, when by words, he never degenerated into rudeness. Mr. Corbet was a somewhat similar character. A gentleman killed him a hound one day. He saw who did it, but, instead of attacking the delinquent point blank, he trotted past him, saying, "They've killed me a favourite hound, sir; you don't happen to know who did it, do you?" On another occasion he just dropped into the delinquent's ear, en passant, "Killed the best hound in the pack, that's all." He caught a gentleman hunting the hounds one day, "Thank you, sir," exclaimed Mr. 
Corbet coming on him unawares; "thank you, sir," repeated he, "but my hounds will do that quite as well without you."

How different to the language of a certain duke under similar circumstances! "Who the hell are you, sir?" exclaimed his grace, coming on an unfortunate wight, hat in hand, capping the hounds.

"And who the hell are you?" replied the stranger, a captain in the sea service.

"They commonly call me the Duke of _-," rejoined his grace, adding, "Now, sir, there are the hounds, hunt them, and be $\mathrm{d}-\mathrm{d}$ to you."

Talking of sailors, reminds us of an amusing account given by Nimrod of a certain nautical M.P. and ex-master of foxhounds' mode of addressing a constituent in the field. "Come here, you ten-pound radical rascal and open this gate." Here is another. A few years back an action was brought by a sailor against a captain of a merchant-man, for ill-usage, when it appearing to be but the second time of "asking," the judge was curious to know Jack's reasons for sailing again with so inhuman a captain.

"Why, please your honour," said Jack, hitching up his trousers, "I war'nt for sailin with him again, but I couldn't help it; the captain has such winning ways with him."

"Winning ways," observed his lordship, "what do you mean by winning ways?" "Why, please my Lord," resumed Jack, "the captain comes alongside me, on the quay, slaps me on the back and says, 'What! Jack, you ill-looking, blear-eyed, squinting scoundrel, arn't you going to sail along with me?'" Jack couldn't resist so touching an appeal.

Beckford gives an amusing account of a Master, whose blowings up combined the "suaviter in modo" with the "fortiter in re."

"An acquaintance of mine," writes he, "a good sportsman, but a very warm one, when he sees the 
company pressing too close upon his hounds, begins crying out, as loud as he can, hold hard I If any one should persist after that, he begins moderately at first, and says, "I beg, sir, you will stop your horse: Pray", sir, stop; God bless you, sir, stop; God d-n your blood, sir, stop your horse!"

Mr. Vyner, in his very able work, "Notitia Venatica," gives the following amusing account of Mr. Nichol, better known as Sam Nichol, in the blowing-up line.

When Mr. Nichol first took the New Forest, he was desperately annoyed by some of the attendants on his hounds, and after vainly begging and beseeching several of the hard-riders, who were wantonly pressing on the pack, to desist, he at length launched out in no measured terms, to the utter astonishment of one unfortunate wight, who claimed the privilege of exhibiting himself, on the plea of being a committee man. "The committee be d-d," replied Nichol, "you are not worth d-ing singly, so I'll d-n you all in a lump."

Mr. Smith in his "Diary of a Huntsman," recommends the indirect or at them, rather than the to them style of rating, such as "Hold hard; pray black horse hold hard!"

The renowned Mr. Jorrocks was doubtless a disciple of Mr. Smith's, for he carried the advice out to the letter, and a little beyond-ex: gra: "Old ard, you air dresser, on the chesnut oss!" "Hair dresser, sir! I am an officer in the 9Ist Regiment." "Then you hossifer in the 9ist Regiment, wot looks like an air dresser, old ard," rejoined Mr. Jorrocks, trotting on.

But enough of bullying, scolding, and riot act reading,-ungracious work at best, and only to be excused under the plea of the infirmities of poor human nature. When the boiler of poor human nature's indignation is insufficient to hold all her steam, let us beseech the owner to get rid of his 
superfluous stock all at once. Let the Master, in fact, say his say and be done, but don't let him incur the censure the nigger passed on his Master, who having flogged him well, began to preach after."Floggey, floggey, or preachey, preachey, massa ; but no both floggey and preachey." Blow up and be done, but don't blow up, and keep "knagging" all the rest of the day.

Remember, if the fault is a flagrant one the field will go with the Master. Their sport is at stake as well as his, but coarse language always disgusts, and the edge of severity is blunted by repetition.

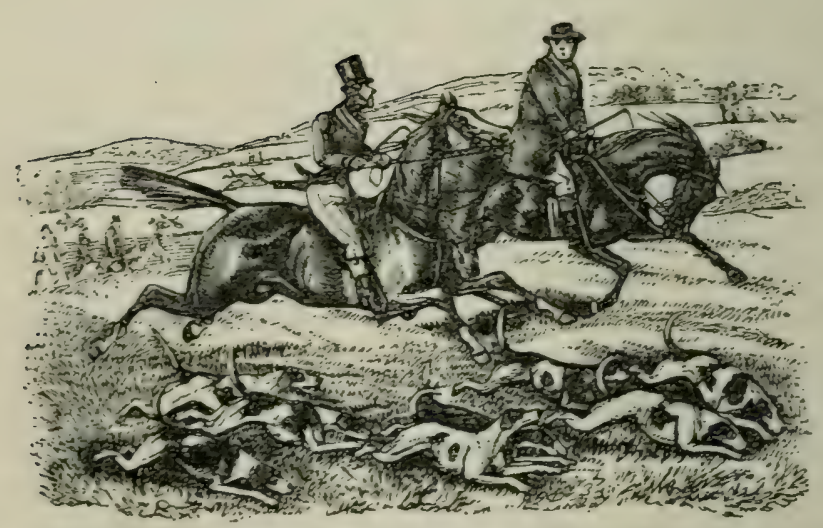

"OLD ARD, YOU AIR DRESSER ON THE CHESNUT OSS!" 


\section{CHAPTER IV}

\section{THE MASTER-concluded}

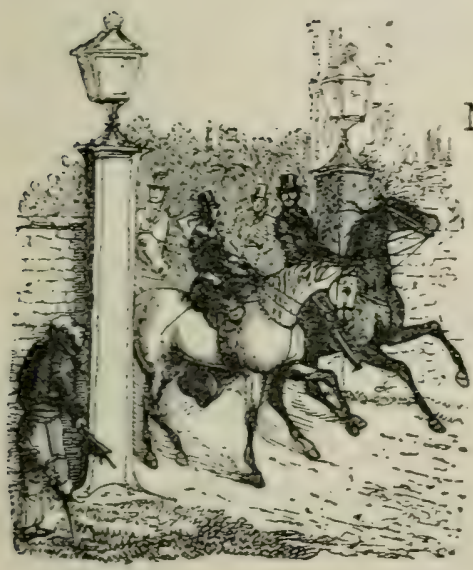

$\mathrm{N}$ dealing with this scribblement, we have treated our "Master" more as a Master than as one of those "rare birds," a Master and huntsman combined. True it is, that in our specification of requirements we lumped the offices, but that was done to show what a "monster of perfection" a gentleman-huntsman ought to be. Dis-Siamese the characters, and we have enough in that of "Master" for all ordinary capacities. Doubtless, in our long life, we have seen many eminent men in duplicate - Darlington, Ducie, Foljambe, Lambton, Musters, Graham, Gifford, Sutton, Osbaldeston, Elcho, Nicholl, Kintore, Newman, Templer, Tatchel, and, though last not least, those mighty fox foes, who have shed renown on the somewhat common name of Smith; but placing the question on its own comprehensive stern, we are very much of the opinion of Beckford, who says, that it is an undertaking which, in a general way, had better be "let alone." 
"It is your opinion, I find," writes Mr. Beckford, and we trust all the foregoing great sportsmen will excuse the freedom with which we have written their names, "It is your opinion, I find," writes Mr. Beckford, "that a gentleman might make the best huntsman; I have no doubt that he would, if he chose the trouble of it."

It is just the "trouble" that chokes people off half the projects and enterprizes of life. If it wasn't the trouble, and perhaps a leetle the fear of Mr. Hardwick, we would give that confounded organ-grinder, who has just struck up under our window, for the third time this morning, an uncommon good quilting, but as it is, we will just sit still and let him grind himself out.

Thank God, he's gone at last, though he has sorely put us out. Let us see what was it we were writing about. Oh, we have it-gentlemen-huntsmen and paid-huntsmen. Well, our next sketch shall be that of a paid "Huntsman," a jolly black-capped, redfaced, purple-lapped huntsman; meanwhile we will glance at the other duties of a "Master," lest the nonhunting portion of the community may suppose "blowing out" and "blowing up" are the only qualifications requisite for one.

For the benefit of embryo gentlemen-huntsmen, we may, however, quote what Colonel Cook wrote on the subject in his "Observations on Foxhunting"-an able work written by a practical sportsman, and published some twenty years ago - "Gentlemen," says he, "should recollect, let their situation in life be ever so exalted, if they condescend to hunt their own hounds, that when in the field they are huntsmen; a huntsman is a public character, and as such is liable to have remarks and criticisms made by the field (who it is always to be remembered are but lookers on, and as such are apt to flatter themselves they know as much 
of the game as the actual player) and to be spoken to by farmers and others on the occurrences which commonly happen in the day's hunting; if things go on well, and the sport is good, the Master of the pack is no doubt the person most pleased, feeling conscious that his exertions contribute much to the amusement of the day; and there is certainly no pleasure more gratifying to ourselves than that of pleasing others. On the contrary, if everything should go on untowardly, which will frequently happen on a bad scenting day, he ought to be mindful that the field likewise participates in his disappointment."

Now for the other qualifications we dotted down in our first paper :-

The generalship of a Master consists in making the most of a country, and the greatest use of his friends. We don't mean to say he is to borrow money or horses of them, but he should urge each individual to put his shoulder stoutly to the wheel to promote the general interest in his particular locality. Thompson's woodman can make up a gap in a cover without trouble or expense; but if the Master has to send a man half-a-dozen or a dozen miles to do it, why there's a day's work. Wise Masters, however, will have nothing to do with covers. They will leave them to the management of those whom Mr. Nichol $\mathrm{d}-\mathrm{d}$ in the aggregate.

Diplomacy, a genteel term for "humbugging," is an essential requisite for a Master of Foxhounds. A Master, like Esop's hare, has generally "many friends," some of whom will advise him diametrically the reverse on the same point. Is it not diplomacy to make each believe you intend doing as he advises, and yet have your own way after all? The necessity for a Master combining the liberality of a sailor with his other qualifications, is sufficiently illustrated in the following observation of Lord Petre, then Master 
of a first-rate establishment, to Mr. Delme Ratcliffe, when about to take the Hertfordshire hounds:"Remember, however," added his lordship, after going through a recapitulation of the hundreds"Remember, however, that, after all this, you will never have your hand out of your pocket, and must always have a guinea in it."

Decision is an indispensable requisite both for "Master" and huntsman. It should be quick as thought; and when once taken, adhered to, unless very cogent reasons appear to the contrary. On this point, perhaps, we cannot do better than quote Colonel Cook. "To hunt a country, and to make the most of it, so as to give general satisfaction, requires some consideration. Supposing you have a thorough knowledge of it, use your own judgment, and never be led by others, for you will find they have most commonly some selfish motives, and will often mislead you. It is a common case," says he, "for a Master of hounds to be requested to draw such and such a covert, ${ }^{1}$ merely because it may happen to accommodate some of the gentlemen out, by lying on their way home; now if an acquiescence in this should cause no inconvenience or material alteration in the arrangements made for the day, it may be all very well to do what you can to oblige any particular person or set of men out; but it should nevertheless be remembered by all the field, that as people are in the habit of coming great distances in every direction, to the point where the hounds meet in the morning, by thus acceding to the wishes of a few you are likely to inconvenience many; besides the probability of occasioning yourself, servants, hounds, and horses (should the draw be from home instead of towards it) to remain out late in a wet December night, without even the moon or stars to guide you. Some men will mislead you to aroid

${ }^{1}$ This chap puts in a "t." -Printer's Devil. 
having their coverts disturbed, fearing a tame pheasant may fly away to his neighbour's preserves. After all, it is best to be firm, and never change the plan of drawing which you have fixed upon and considered to be the most probable one for sport.

"A country ought to be regularly hunted, the good and the bad alternately, to give general satisfaction, and in the long run you will have a better chance of sport. If you are continually disturbing your best country you may have blank days, and the foxes will be very shy; where there are many earths they will lay at ground. There can be no doubt but it must be more agreeable to hunt a good country always, if you have extent enough for an open season. Provided you cannot hunt the inferior one, so as to give satisfaction, it is more liberal to give it up altogether to some neighbouring pack, or even to some one from a distance, who might be glad to hunt it regularly. The keeping a country, or requiring owners of covers to preserve, without hunting it, is too much to expect, and gives people an opportunity of alluding to the story of the dog in the manger."

Mr. Pryse Pryse, an old Master, summed up the relative duties of himself and field very ably, in the following words, at a dinner given him by the Goggerdan Hunt, some years since:- "As a Master of Hounds," said he, "I have many things to expect. I have a right to expect a strict preservation of foxes from every one. I have a right to expect old foxes, and also a strict preservation of cubs ; for, without young foxes, the stock cannot be kept up, and blank days will be the result." [Mr. Pryse Pryse would seem to have been hitting at some of the Cottonwool tribe.]

"On the other hand," continues he, "you have a right to expect from me the most polite attention in the field, and out of the field, to expect a correct 
announcement of all the meets; in fact you have a right to expect me to hunt the country, not for my own convenience, but to the satisfaction and amusement of others."

Some people, we may observe, are very difficult to please, and very unreasonable in their expectations about hunting, especially on the point of hounds going out without due notice. Nothing can be more absurd, for any one who has watched the weather and localities, must be aware that, during the ticklish part of the season, hounds can often hunt in one part of a country and not in another, and that "hunt" or "no hunt" is sometimes the work of one capricious hour. When the electric telegraph is established throughout the country, out-lying gentlemen will have a better chance of being communicated with, but eren then we question whether any of the grumblers will come or not. As things stand, parties nearest the kennel have the best chance, and properly so. Some people are as difficult to please about their hunting as the soldier was about his flogging.

Mr. Beckford appears to have been clear both of subscribers, clubs, committees, and all the modern paraphernalia of the chase, most likely paying everything himself, and accommodating such sportsmen as chose to come to him on his own terms. At all events his book is silent on the management of a country, as it is called, though he makes a distinction between managing a pack of hounds and hunting them. On the former point he says: "Some art may be necessary to make the most of the country that you hunt. I would advise you not to draw the covers near your house while you can find elsewhere; it will make them certain places to find in when you go out late, or may otherwise be in want of them. For the same reason, I would advise you not to hunt those covers late in the season. They should not be much disturbed after Christmas. Foxes will them 
resort to them, will breed there, and you can preserve them with little trouble."

We have heard various opinions as to the best man to hunt a country, some advocating native Masters, others contending that strangers are the best. It is a point on which much may be said on both sides, though the great question hinges on the style of man himself. Perhaps it may not be an unfair proposition to lay down, that a popular resident gentleman is most likely to be agreeable to the farmers, while a sportsman of established reputation and station may unite the whole foxhunting force, and prevent the petty jealousies that sometimes arise when a Master is drawn from the "body of the county," as they say of a jury. Farmers will put up with a great deal from a man they know. It is "stranger damage" they object to-townsmen's particularly, not one in ten knowing what they are riding over. "A lord," we may add, is a trump card anywhere.

If we thought a Mastership and the duties of huntsman too much for one man, what shall we say to the triplicate character of a Master supported by subscription and hunting the hounds? We think we may say that a successful one is little short of a miracle, an eighth wonder of the world, at all events. We all know the ease and readiness with which people find fault. Hunting critics, like Lord Byron's reviewing ones, "are ready made ;" and some think it necessary to censure, just as others think it right to halloo, according to the amount of their subscriptions. Nay, we have heard of men censuring to escape subscribing, just as skinflint travellers used to pick holes with guards and coachmen, to escape paying them. The "hallooing and hunting tariff" was thus laid down by Nimrod some years ago, and as no mention has been made of it in any of Sir Robert Peel's new ones, we suppose it remains the same, viz., the man who subscribes twenty-five pounds a-year may halloo once, 
fifty twice; but, if he give a hundred, he may halloo all day long.

Hunt subscriptions are as difficult to realise as the assets of a bankrupt tommy shopkeeper. Unless there is a huge nest egg to start with, it is weary uphill work trying to keep a pack of hounds by what the hospital people call "voluntary contributions." Voluntary contributions, forsooth! We read in the "Old Sporting Magazine," that, at a fashionable Spa, a poor laundress had been mulct of her few shillings towards the keep of what brought the white breeches to her tub. This is not as it should be. Much as we desire to uphold hunting, yet we must advocate its support on proper gentlemanly principles. Better knock-off a day a-week than resort to such means. If such expedients are had recourse to, at idle, moneyspending watering-places, what can we expect from the hard money-getting penury of the country.

Some people may suppose that a Mastership of Hounds is fulfilled with the mere home and field management, but such is very far from being the case. A Master of Hounds exercises no small influence on the manners, we might almost say, the morals of a country, as well by his own example as by the style of people his management brings about him. Mankind are prone to imitation-young men, especially; and a Master of Hounds is of all others the most likely for them to look up to.

\section{"He who excels in what we prize, Appears a hero in our eyes."}

If the Master is what may be termed a show foxhunter-a dandified petit maitre-he will have every chance of making the field the same, for many will be glad to add what we may call the "impotence of dress" to the general attractions of the red coat. If the Master is a coarse, swearing, overbearing fellow, his companions will be the same; for there is no 
truer saying, than that "birds of a feather flock together," and none but blackguards will put up with one; but if our Master is what a Master ought to be-a high-minded, liberal, gentlemanly man, affable with his equals, courteous to all, keen without pedantry, neat without puppyism-he will not only raise the character of foxhunting generally, but will exercise a most wholesome influence on the minds and manners of the rising generation within his own peculiar sphere. And this leads us to observe, that there is not, perhaps, in the whole range of the duties of a Master, an act admitting of such graceful compliments as the judicious presentation of the brush. It is in trifles such as this that tact and gentlemanly feeling are shown. If a lady, Henrietta Cottonwool, for instance, is out looking after Smashgate, the flattering trophy, of course will be hers. If not, the claims of the rising generation may be considered. The younger the recipient the greater the charm. "My first brush" is a recollection that will survive the more important features of life. A stranger may be complimented. "That brush was given me by the "best fellow under the sun,' after a good hour and twenty minutes, finding at Waterloo Gorse, in the Harborough country, and running right up into the heart of Leicestershire," is a fine speech for a Devonshire sportsman to make to his provincial friends, as they sit sipping their port and toasting their toes over the fire, on whose ancient mantel-piece the proud trophy is stuck. The pads, too, may be turned to account in the way of minor compliments. Some men keep pad-deries.

Hunt dinners are nasty things, but upon the whole, perhaps, they are advisable. If men ever have their purses in their pockets-a problem that we almost doubt with regard to some of the community-it will most likely be at "a hand in the pocket" dinner, as hunt ones invariably are, and an "insinivating" secretary may cajole reluctant sovereigns from those 
whom no penny postage efforts would move. Wonderful world this! Men talk of their thousands, from whom it is easier to extract an eye-tooth than a sovereign.

In speaking of a "hunt dinner," we mean one of those general hawls, that are meant to include "all the world and his wife," every one friendly to foxhunting, and not the ordinary mess of sportsmen at their own wine depôt. The latter are generally very pleasant meetings, especially when divested of form, speechifying, health-drinking, and so on. Toasts should never be resorted to so long as men can talk. They are sure to bring conversation to a check. But to business. We have had our Master in Cottonwool's domestic circle, we must now transport him to a worse scene-a hunt dinner at a country inn- "time being called," as Nimrod says in the Quarterly - "say a quarter to six-nearly our great-grandfather's supperhour," sundry boors in boots, and sundry boots in shoes, are seen wending their ways in charge of sundry buckets of soup, roasts and boils, sirloins, saddles, rounds, geese, sucking pig, a haunch of venison, game, tarts, celery, etc. By the time the odd quarter of an hour has elapsed they have got them set square on the table, and all having cooled alike, "the Master," who sometimes plays the double part of "host" and "cock guest," leads the way from the travellers' room, where the company have been deposited in the enjoyment of damp great coats and stale smoke, followed by all the "train band bold," who forthwith commence a desperate onslaught on the wittles.

But our humane disposition shrinks from describing the horrors of the evening - the hot wine and cold soup-the fatless venison and the gravy-congealed mutton. Taking old Cottonwool's for the alternative, we may truly say "the last state of this Master is worse than the first." Wool's had the redeeming quality of women-here it is all men. Instead of first 
a foxhunter, then a lump of Cottonwool, etc., it is foxhunter and "preterea nihil." The only variety is here and there a stranger, or man in morning's black coat dotted in among the orange vermillion ones of the hunt. A wretched old hack song, sung by a man with a spavin'd voice and a desperate running at the nose, is all we have in lieu of the vigorous but not unpleasant playing of the Miss Cottonwools. But we are getting in advance of the evening; for though we spared the dinner we must have the speech. "Brief let it be," as old Hamlet-not the jeweller-but the

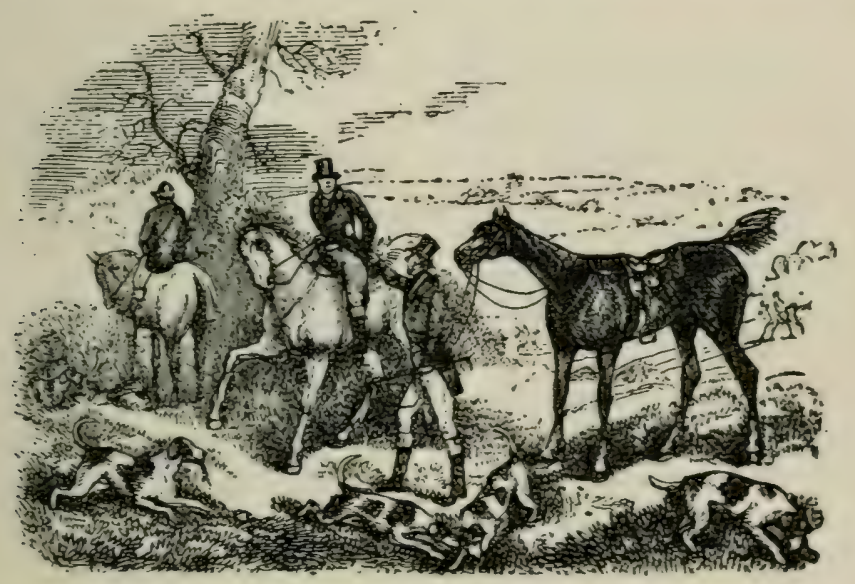

ghost of that name said. Yarn spinning is only for harehunters. The best speech we ever read, was one of the late Lord Kintore's, delivered on the presentation of a piece of plate. A "Ciceronian Master" will easily adapt it to a "health," returning one for himself. "Gentlemen," said his lordship, "I hardly know how to thank you for this totally uncalled for, and most unmerited mark of your friendship towards me. If, during the dull winter months, the foxhounds have shown you any sport, it has been owing to your individual exertions in having preserved the foxes, in 
having cut rides, etc., in your covers, with, I trust and hope I may add the goodwill of the tenantry to boot, that has enabled me to show you sport. To you both I return my hearty thanks. But to you, gentlemen, here present, in particular, I cannot sufficiently express how much I appreciate this kindness, and can now only beg you to accept the humble but grateful thanks of an individual whose soul from his cradle has been rivetted to the chase, and who will ever hold fast, until the earth receives him, this distinguished token of your goodwill. Gentlemen, I have the honour to drink your good healths, sincerely wishing from my heart, that unanimity, good-fellowship, and foxhunting, may long flourish, in this northern, but, most hospitable "land of cakes."

That's a true sportsman's speech! Woe with the day that took so good a Master from among us! 


\section{CHAPTER V}

THE HUNTSMAN

"A huntsman's fame rises and falls with the sport he shows."

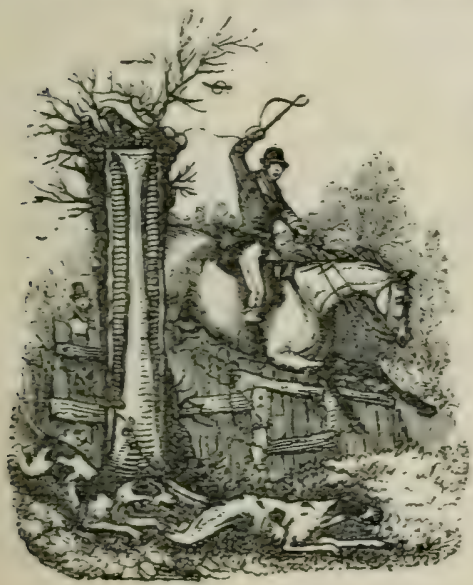

$F$ we take the whole range of servitude, we shall not find any more deserving of encouragement than huntsmen and kennel servants generally. There are none more respectable in their conduct, none more energetic in their calling, none more faithful to their employers, and none more obliging to the world at large.

A huntsman occupies a somewhat middle station in spciety, veering between equality and servitude. To a certain extent a huntsman must be the companion and confidant of the "Master," a feeling that generally extends itself to the hunting field. Indeed, it is impossible not to feel a more than ordinary interest for men imbued with the same passion, transported by the same pleasures, and daily hazarding life and limb in the furtherance of our enjoyments. Doubly strong it is when the object is connected with our earliest recollections and associations. Beckford, 
that great sporting luminary, without whose book we "little goes" would get badly on, thus "endeavours," as he says, to describe what a good Huntsman ought to be. "He should," says he, "be young, strong, active, bold, and enterprising; fond of the diversion, and indefatigable in the pursuit of it; he should be sensible and good-tempered; he ought also to be sober; he should be exact, civil, and cleanly; he should be a good horseman and a good groom; his voice should be strong and clear; and he should have an eye so quick as to perceive which of the hounds carries the scent, when all are running; and should have so excellent an ear as always to distinguish the foremost hounds when he does not see them; he should be quiet, patient, and without conceit. Such are the excellencies which constitute a good huntsman; he should not, however, be too fond of displaying them, till necessity calls them forth. He should let his hounds alone, whilst they can hunt, and he should have genius to assist them when they cannot."

We think Mr. Beckford has left but little unsaid in his catalogue of qualifications, though many of them hinge on the first one, that of "youth." Doubtless, perpetual evergreenism is a most desirable thing, and in engaging a Huntsman, perhaps a Master of Hounds would hesitate ere he took one in the decline of life; but, still, somethinglshould be allowed for experience, and a Master should bear in mind the many remarkable men we have seen, some of whom combatted not only with age but with weight.

Who can forget jolly old Roffey, that Surrey trump, or Stephen Goodall, in Oxfordshire, men who were loads for dray horses; or, in point of years, old Ben Jennings, in Dorsetshire, with his silvery locks; or Will Neverd, Mr. Warde's old Huntsman, who took a fresh place at seventy; or old Tom Rose, the late Duke of Grafton's Huntsman, who hunted the hounds till near eighty; or Winter, with Mr. Lambton; or 
Dick Forster, Mr. Villebois's old Huntsman, reckoned the best woodland one of the day; or Oldacre, with the Berkeley; or Lambert, with Lord Lonsdale; or old Tom Leedham, with Mr. Meynell, or Mr. Meynell Ingram, as he is now called; and doubtless many others, whose names do not occur at this moment to our recollection?

Some of the best men of recent times are on the wrong side of fifty-Goosey, Sebright, Shirley, Williamson, Walker, Burton, and, if we mistake not, Will Long. Davis, too, the Queen's huntsman, is advancing, and Tom Hill must be getting on, both in beef and age, but no one can do the trick like Tom on the Surrey hills. He ought to be called Lord Hill.

Mr. Smith, late Master of the Pytchley and Craven Hunts, thus sums up his list of requisites for a Huntsman in his "Diary of a Huntsman." "To be perfect," says he, "a Huntsman should possess the following qualifications :-Health, memory, decision, temper and patience, voice and sight, courage and spirits, perseverance, activity; and with these he will soon make a bad pack a good one. If quick, he will make a slow pack quick; if slow, he will make a quick pack slow."

The following capital advice cannot perhaps be more seasonably introduced than at the present moment :

"But first, to become a good one he must have a fair chance," says Mr. Smith, "and should not be interfered with by any one after he leaves the place of meeting; previous to which, on all occasions, it would be best if the Master of hounds was to arrange with him which covers should be drawn first, etc. It rarely happens that two men think exactly alike, and unless he is capable of judging for himself after the above arrangement (which had much better be done over night) the Master is to blame in keeping him ; but 
if he is capable, the Master is to blame by interfering; for, consequently, the man will be ever thinkingwhat does Master think? and will not gain that independence of thought and action so necessary to be a match for a fox on most occasions; for instance, at a check there are many apparently trifling ideas and thoughts in a Huntsman's head, which he cannot explain to his Master, if asked why he does this or that; but, instead of answering, drops his bridle hand and listens to his Master, although he has made observations of trifles which are often all he has for his guidance, and frequently are sufficient to recover his fox; but probably no other person noticed them - such as this: The pack is running best pace; he sees one hound turn his head, and fling to the right or left a pace or two. Shortly after there is a check (say 500 yards); when he has made the usual casts he recollects the hound turning his head, and then goes back so far, and hits off the scent; but he could or could not tell any one why he was going back. It is such like trifling observations that Huntsmen profit by, though unnoticed by others.

It is the want of decision that makes committees such deplorable things. There is so much hesitation, so much stopping, so much debating, so much chopping and changing, that the indecision of the Masters communicates itself to the field. We never see a lot of committee-men clubbing heads with the Huntsman without being tempted to ask for the "ballot-box." Give us a good absolute monarchy! None of your three or four Kings of Brentford, all smelling at the same nosegay! Gentlemen who navigate the Thames cannot fail to have observed a notice "not to speak to the man at the wheel," and in addition to the excellent hint Mr. Smith gives to "Masters," it would be very desirable to inculcate some such precept as the steam-boat one upon the field at large. A Huntsman, at all events, after he 
leaves the meet, has something else to do than receive and exchange the compliments of the morning, talk of the weather, the state of the country, or the filth of the roads. He should be running over the day's work in his mind's eye, thinking what he did when he was last at the cover he is now going to draw, considering what is the difference in the day, and a hundred other things, "too numerous to insert in a handbill," as the auctioneers say. Young gentlemen in jackets, and, indeed, middle-aged ones in new scarlet coats, must not, therefore, take it amiss if Huntsmen become strangely monosyllabic after leaving the meet, nor must they set them down as grumpey and ill-natured if they don't laugh at their wit.

With the reader's permission we will take another slice of Smith-rather fatter, too, than the last. "That a Huntsman should be a good rider," says he, "is proved by every check the hounds come to when he is away; for even when he is present he will have enough to do to prevent over-riding; but unless he can ride at head, and see the very spot on which they throw up, he will be puzzled to know who of those up to apply to, and must often use his own judgment ; in short, the greatest use he can be of, when on a good scent, is to prevent men doing mischief; therefore he must have nerve to ride well up, and equal to any man in the kingdom; for, unless he can be forward enough to look men in the face and request them to hold hard, he may ride behind and call after them till he is hoarse, and they will not turn their heads, probably believing that jealousy alone is the cause, and they go the faster for it; but, if he is in his place, none but a madman will do mischief if requested to pull up: even the hard riders from the universities (that is, if they can stop their horses) will do so."

Some Huntsmen are far greater fidgets about their 
hounds than others, both on the road and in the field. It is doubtless advisable always to keep hounds clear of horses; but as there is generally some gentleman who will "talk to the man at the wheel," and as no one likes to be last, even on the road, the consequence is the field will crowd to the head. Some Huntsmen have their hounds all huddled round their horse's heels, others will give them as much line as a regiment of guards, but perhaps the best course is to keep them together in a crowd, and give them room when alone.

We are not, however, going to set up to teach Huntsmen their business, fearing we might get the rebuke Naylor, the York and Ainsty Huntsman, administered to Nimrod, when he said "he had forgotten more than Nimrod ever knew ;" but there are a few observations of Mr. Smith, himself a gentleman-huntsman of no small celebrity, that may be administered like a cordial ball without ruffling the coat. Here is one. "There is nothing more disheartening to a field of sportsmen than for a Huntsman, or Master of Hounds, to trifle with them by pretending to draw for a fox, when it is evident they do not intend to let the hounds find one if they can help it, by taking them through the parts of a cover quickly where there is no laying, although there is good on the other side, which they avoid, and it would be a certain find if they would let the hounds draw it; or probably missing other sure places, and drawing unlikely ones, until their time is spun out that they may go home."

Of course there are days-windy ones, for instance -or days when few sportsmen are out, on which it is desirable to shut up as soon as possible; but in these cases it is always well to give the "regulars" the hint, by doing which Huntsmen will not only save censure, but the retirement of the forces will materially aid their retreat with the hounds. There 
is a discretion, however, in all this, which shows the man with the head from the man without. Tom Babbleton would tell all the country that they merely took the hounds out for show, while Sir Rasper Smashgate, or old Peter Pigskin, would acknowledge the propriety of the step and go home at once. Few sportsmen like to leave hounds while a chance of sport remains. Here is another hint. "When a Huntsman is requested to draw for a second fox late in the day, it would be fair to say, 'Gentlemen, we have had work lately, and have some distance home; but if I do find, will you promise not to leave me till it is finished?" Some men are very inconsiderate and unreasonable, never thinking hounds, horses, or men can do too much when they happen to be out, especially if the draw they recommend is in their way home.

But to the qualifications of a Huntsman:Beckford said "he was not very ambitious of having a famous Huntsman, unless it necessarily followed that he must have famous hounds; a conclusion," writes he, "I cannot admit as long as these so famous gentlemen will be continually attempting themselves to do what would be much better done if left to their hounds; besides, they seldom are good servants, are always conceited, and sometimes impertinent. I am very well satisfied if my Huntsman be acquainted with his country and his hounds, if he ride well up to them, and if he have some knowledge of the nature of the animal which he is in pursuit of ; but so far am I from wishing him to be famous, that I hope he will continue to think his hounds know best how to hunt a fox."

If we were hiring a Huntsman, we should like him to be bred in the hunting line. We cannot fancy a house-painter's or cobbler's son assuming the saddle and horn, and setting up as Huntsman. Doubtless there are fellows who have impudence enough to set 
up for anything-archbishops, if they saw an opening -and we think they would almost as soon fulfil the duties of one as the other. It is not every widethroated fellow with "nought to do, and who likes hontin vastly," as they say in Yorkshire, that will make a Huntsman-not a Huntsman to foxhounds, though we are not sure but a good bow-backed pedestrian, with his head well down to the ground for "pricking," would not make as good a harrier Huntsman as the best. The two offices are as different as horse-riding and donkey-riding. They both "go," certainly, but the "stop" of the business is the thing. And yet we have seen fellows who, because they have been able to circumvent a hare, have thought themselves qualified for foxhounds. The simile of the horse and the ass may be carried still further. Turn a horse loose and you don't know where he will go; but give a donkey his head, and see if he won't stop. It is just the same with a fox and a hare. You never know where a fox is bound, but a hare is almost invariably within the circle of the "magic ring." The fox is travelling, the hare perhaps squatting under your horse's feet. So far from having hunted harriers being a qualification for hunting foxhounds, we should say it was a downright objection. You have to unteach the harrier man all he knows, before you begin to teach. Better have a fresh horn and begin a new spoon. We would rather have a fellow from the roughest pack going, whose constant pursuit had been "fox," than one of these psalm-singing gentry. Not that we decry harehunting as a sport; legitimately followed it is capital amusement, but we should never take a Huntsman for foxhounds from a pack of harriers. Instead of thinking which way the fox had gone, he would be always thinking which way he had come.

We once heard of a harrier genius who, on the 
strength of having successfully manceuvred some ten or twelve couple of waffling beggars, undertook the situation of Huntsman to a scratch pack of foxhounds. A scratch pack of foxhounds, especially a newly set up one, is always a dangerous thing. You have all the wild, resolute, vigorous power of the animal without the discipline; added to this, they are generally composed of the wild, vicious, savage hounds of other packs; things that escape hanging by going to scratch ones. Having, however, subdued the merry mettle of the harriers, generally with a rate, at all events with a cut of a whip, our hero thinking foxhounds were to be similarly kept down, "broke kennel" the morning after his somewhat sudden installation, with a very riotous crew at his horse's heels. He got to the place of meeting with his own and the noisy efforts of a young clown in boots, and the field began to assemble. The meet was in a valley, and unfortunately on the opposite hill were some newly stubbed, but faded gorse bushes. A slight breeze caught one of these, and set it a going on the brow of the hill. The hounds caught view and dashed away full cry, Soup and Chaw riding, rating, and rioting, which the hounds were just as likely to take for encouragement as not. On they went full cry, at a most determined pace, when, wonderful to relate, Chaw instead of riding at their sterns, got round them, and with uplifted whip was about commencing operations, when the horse, unused to such a charge, suddenly stopped short; Chaw pitched over its head; away went the horse with the hounds full cry after it, for two miles, when fortunately or unfortunately, according to the value of the respective animals, a flock of sheep interposed, or as Soup deposed, he verily believed they would have eaten horse saddle and all. As it was, they compounded by taking several saddles of mutton. This, it may be said, 
might have happened to any pack; indeed Beckford relates a somewhat similar accident with his hounds, owing to the falling off of a whipper-in at exercise; but it is nevertheless perfectly true, that an acquaintance with harriers unfits a man for appreciating the discipline requisite for foxhounds. They think too lightly of it. They are like a friend of ours, who being asked if he thought he could edit a Newspaper, replied "he thought any old woman in their workhouse could do that."

Huntsmen are well aware of the feeling of harrier huntsmen, and some of them seem to take a pleasure in selling an innocent a bargain. We once overheard a dialogue between a young scratch pack gentleman Huntsman and a top-sawyer, which concluded by the young one, after sundry sporting and pertinent questions about a draft he had recently got, saying, he "supposed they had never worried sheep." "Oh, no, sir," replied the Huntsman with a shake of his head and touch of his cap, adding, sotto voce, to a friend at his side, "but they $d-d$ soon will."

A "real tool," or "cake," of a Huntsman is a thing one rarely meets with, at least not in a civilized country. We once saw a fellow arrive in a greasy hat, and an old drab great coat over an older red one, on a visit of inspection to another pack, who was pointed out as Huntsman to the Scampington hounds, and very like the thing he looked. They said he was the cleverest hand at drawing on a public house that ever was seen; no matter whether he had ever been in the country before or not, he could always find them, and his nose did credit to the liquor. As to hunting a pack of hounds he had not the slightest idea. When at length he got straggled up at a check, instead of making a cast at once with promptitude and decision, he would sit on his horse exclaiming, "Ah, dear! whichiver way can he have gone? Which way do you think he's 
gone, Mr. Brown? Which way do you, Mr. Green?"

Huntsmen-hounds, servants in general-have one charming quality; they look down upon every other species of amusement with the most superlative contempt. We like this. It shows genuine enthusiasm, without which there is little chance for anything in this world. We never heard or read of but one servant who followed hunting merely as a livelihood, without reference to the enjoyment, and without having any natural inclination that way, or indeed any pleasure in the chase, and that was a man of the name of Filer, formerly Huntsman to the Craven hounds, who used candidly to say, "he never liked foxhunting, but having been bred up with hounds he would stick to them." We have heard of men being brought up to the bar, the sea, or the church, and not liking their professions, but sticking to them; but really, for a man to stick to hunting merely because he had been brought up with hounds, does seem a piece of pure self-devotion. $\mathrm{He}$ had better have turned policeman. How different to some of the stories that Beckford and Cook tell! Old Luke Freeman, who hunted Lord Egremont's hounds, used to say to his lordship's sons, when he caught them reading, "Stoody, stoody, stoody! aye studying they books! take, I say, my advice, sir, and stoody foxhunting." Luke, Colonel Cook says, gave his whole body and mind to it, and famously he succeeded, as all the country around could testify. A wag, for amusement, and to annoy a musical friend that was present, asked the old Huntsman "how he employed his time out of the hunting season?" The veteran disdained a reply to a question that showed so little knowledge of the duties and cares of a Huntsman, and the querist proceeded with, "What think you of music for an amusement?" "Music!" contemptuously echoed Luke. "Ay, fiddling, Mr. 
Freeman." "Fiddling, fiddling," replied Luke; "it's all very well for cripples, poor things! I always give them a halfpenny when I sees them at the fairs." Beckford has a cut at the musicians also. "Louis the Fifteenth," writes he, "was so passionately fond of hunting that it occupied him entirely. The then King of Prussia, who never hunted, gave up a great deal of his time to music, and himself played on the flute. A German meeting a Frenchman, asked him, very impertinently, 'Si son maitre chassoit toujours?' 'Oui, oui,' replied the other, 'il ne joue jamais de la flute." "

A Huntsman's head generally runs upon hunting. If he rides, or rails through a country, he looks at it with reference to riding over it. If he examines the crops, it is merely to see when they will be ripe. Woodland scenery draws forth observations upon cubhunting. Hills are looked at with an eye to the easiest way up. When Williamson, the Duke of Buccleuch's Huntsman, visited London, his Grace told him he must see the sights. "But," replied Wool, as they call him, though he is no relation of our friend Cottonwool, "I don't know the country, and shall be lost." His Grace then sent him out on horseback, with a groom after him, and Nimrod says Wool was taken for a newly-made lord. Talking of countries reminds us of a story they used to tell of the late Lord Spencer, when Lord Althorp, and Dick Knight, his Huntsman. His lordship had been talking at the meet to some gentlemen about political matters, and had made use of the old hack observation that the "country was ruined"

"Ah," said Dick Knight, with a sigh, "they ruined the country when they made the Oxford Canal."

It is singular that such a narrow strip of water as the British Channel should make such a perfect division between the tastes, the feelings, and inclinations of the people. What would be prized and 
followed at Dover would be scouted and laughed at at Calais or Boulogne. We are alluding, of course, to hounds, for which the French have not the slightest feeling, inclination, or sympathy. Children in England all rush with delight to see them passFrench ones stare and wonder if the "soldiers" are going to kill and eat them up with the dogs. Hunting is quite the peculiar taste of Britons, and let people say what they will, it must exercise a most beneficial influence on the national character. Let any one look at a field of foxhunters in full chase, and say whether such men are likely to be stopped at a trifle or not. Above all, let them look at the Huntsmen and Whip, and fancy them with swords in their hands instead of whips. Why, they would charge a regiment of devils in complete armour! The Duke of Wellington, himself a foxhunter, and a real friend to the sport, used to say that for daring, dashing deeds, there were none like the foxhunting officers. We believe he generally selected them to carry despatches and other difficult duties on the battle-field.

A Frenchman looks at the "Chasse," a term they apply equally to sparrow-shooting and stag-hunting, as a mere means of achieving an end with the smallest possible trouble. They can't understand the wit of giving ourselves the trouble of pursuing an animal over hill and dale, that we can exterminate at first sight. They are all for lead. Colonel Cook, who resided many years in France, relates how that having some ten couple of hounds consigned to him, he took them into the Duke de Albufera (Suchet's) covers at Tankerville, and after a long draw found a fox in a piece of gorse in an open country, which being immediately headed into the mouth of the hounds, a French gentleman rode up, and taking off his hat, exclaimed, "Sir, I congratulate you on catching him so soon, and with so little trouble!" Frenchmen 
have a mortal horror of the idea of a pack of hounds, imagining that if they once get into a cover they will destroy every living thing in it. On this occasion, however, those that were out found great fault with the chiens Anglais, asserting they were good for nothing, for they would neither hunt hares, rabbits, nor rats.

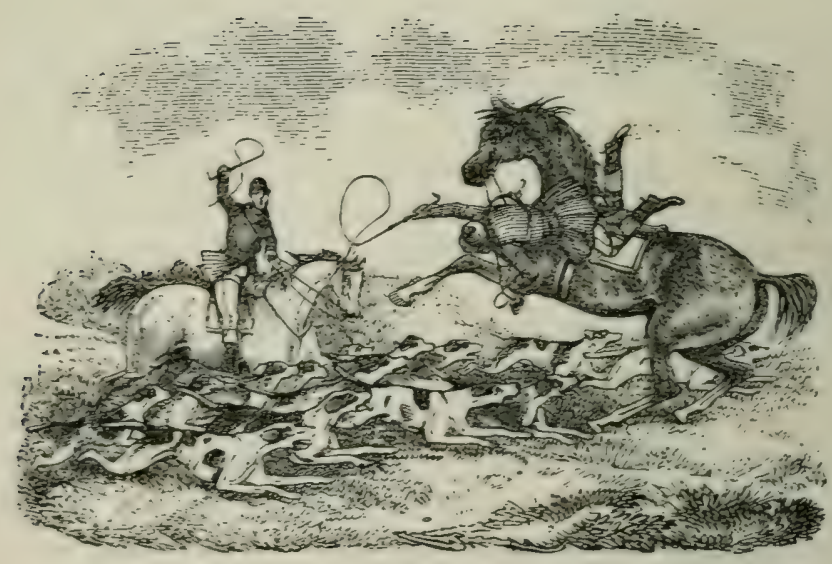




\section{CHAPTER VI}

\section{THE HUNTSMAN - continued}

"I have always thought a Huntsman a happy man; his office is pleasing, and at the same time flattering; we pay him for that which diverts him, and he is enriched by his greatest pleasure; nor is a general after a victory more proud than is a Huntsman who returns with his fox's head."-BECKFORD.

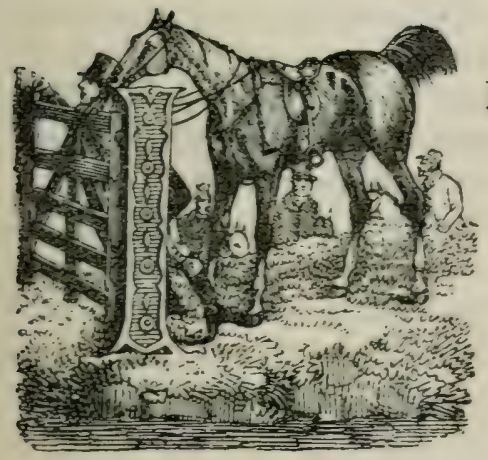

$\mathrm{N}$ our last we glanced at the character and some of the duties of the Huntsmen, and ran over the names of several who have distinguished themselves in their calling. The list was composed more of by-gone or fading flowers than of the rising geniuses of the present day, because it creates no jealousy to award praise where all allow it, and our object in writing these sketches is to encourage a wholesome spirit of hunting, and not to flatter this man or that at the expense of his neighbours. Comparisons are always odious to some one, and there is no truer saying than that a Huntsman's fame rises and falls with the sport he shows. At the same time it is but justice to add, that there are many Huntsmen at work in our different counties whose fame will bear comparison with the best of those gone 
by. When their waning day arrives, may some abler pen portray their merits.

The Huntsman of our Analysis is one of the old school; his father was Huntsman before him, his sons now whip in to him. He has neither read Beckford "On Hunting," nor Nimrod on "Condition of Hunters," but he can kill a fox with any man going, and turn out his horse in as good condition as the best. He carries his library in his head-experience. Look at the old boy as he sits astride his glossy, well-conditioned black, his venerable gray locks protruding beneath his new black cap, his spic and span coat, his fortieth scarlet, with the stout drab breeches and mahogany tops. He sits on his horse as if he were a part of him. Old Will is our Huntsman's name. He most likely has another, but we never heard him called by anything else, and possibly he may have forgotten his surname himself. Old Will and young Will and Will junior (or sweet Will, as the girls call the young one, who is a bachelor), are the trio now moving the hounds about on the bright green sward, for Will, though no painter, knows that there is nothing like a dark background for setting off colours to advantage. How quiet he is with the hounds! He gives them their fling, too, instead of having them cowering under his horse's legs to aroid the sting of the Whipper-in's lash, but a gentle "here again," with a slight wave of the hand, brings the outsiders frolicking back to his call. How much better than the noisy, bullying clamour of idiot boys, showing off, by the loudness of their rates, the severity of their cuts, and the thrashing of their horses.

There isn't a gap, or a gate, or a hole in the wall in the country, that Old Will does not know, and that he hasn't been over or through a hundred times. Time has slackened his leaping powers, but he is a capital hand at screwing through awkward places, 
and he always saves his horse in anticipation of a long day. He never seems in a hurry, and yet he is always near his hounds; he never gallops when he can trot, or takes a leap when he can go through a gap. Old Will is sixty-seven, but he is not older than most men at fifty. He has not an ounce-of superfluous flesh upon him, and is as equal to four days a week as he was at twenty.

Will and his Whips are turned out as they should be. They look as if they were going to ride across country instead of to canter up and down Rotten Row after my lord or my lady. We don't like to see dandified Huntsmen and whips. Over-dressed gentlemen are bad enough in the field, let us have no over-dressed servants. Shooters always put on their stoutest and worst things, wet or dry, wood or open; but some foxhunters seem to think that only the best of everything will do for hunting. Then, if they get to the meet in apple-pie order, they don't care how soon after they spoil themselves, save and except, and always reserved, the Muffs and Fribbleton Browns who are going to lunch with the Miss Cottonwools. They don't care how soon they get away after the pride of the meet is over.

Huntsmen and Whips should all wear caps. Nothing looks so ugly as servants in hats. Strange that Lord Darlington, who was painted by Marshall in the cap and spare stirrup-leather of the Huntsman, should, in his ducal days, have put his men in hats. Lord Lonsdale, too, had his in them latterly, and very slow they looked. Hats should only be worn at exercise. Modern times have introduced some frightful projections at the back of some hunting caps, like sheds thrown out at the backs of lodges. On inquiry, we found they were meant to turn the wet off the wearer's back. The same purpose would be answered by turning the cap peak backwards in wet weather, as Tom Rounding used to do at a wet 
Epping hunt. This would save the wearer's neck, and also the disfigurement of an otherwise sporting and seemly article of dress. The projections make caps look like barbers' basons. Gentlemen never look well in caps. A cap and a frock coat should always go together. A gentleman in a cutaway coat and a cap looks as absurd as a courtier would in a round hat.

Leather breeches are stupid things for field servants. If the breeches are good, they are heavy, and require a deal of cleaning to keep them in order, and nothing can be more unsightly than thin, dingy, parchmentlooking, ill-kept ones. Hunting servants have plenty to do without cleaning leather breeches. Lord Yarborough's men, we believe, wear them; but it is not every Master that has his lordship's purse. His lordship's men are the only ones we ever saw really well turned out in leathers. The Warwickshire men used to wear them in Boxall's time, but they would have looked better in cords. The Atherstone men, in Mr. Applewaite's time, were as well turned out as any men of the day, in neat cords, all the same colour and pattern.

Servants' dress should be stout, warm, and weather defying. They have many a weary, trashing, cold ride, both of a morning and an evening, that the generality of hound followers know nothing about. If the generality of men find the hounds at the meet at half-past ten or eleven, they neither care to know whence they came, nor whither they go. They look at them, much as people look at a play; at a certain hour they expect to find the doors open, and "nosey". scraping his fiddle in the orchestra, after which all is looked upon as a mere matter of course; they are but spectators, free to stay or go as the humour seizes them. The Huntsmen and whips, however, must stay till the close of the entertainment, sometimes longer, unless, indeed, the Huntsman is content to 
go away, leaving lost hounds to "follow on," as a treasure of a man we knew used to say. We spoke in the past tense, but we know him still, only he carries a horn with letters on a mule, instead of pretending to hunt hounds, and he seems quite in his right place now.

The Huntsman is the main spring in the machinery of a hunting establishment, and upon his good conduct greatly depends the comfort and pleasure of the Master. If the Huntsman is - what we must do them the justice of saying the generality of them are-a steady, honest, careful, accurate, economical, intelligent, painstaking man, holding the money scales fairly between his master and the public, neither cheating himself, nor suffering others to cheat, soothing asperities, rather than creating them, demolishing difficulties rather than raising them; he will be a credit to himself, a comfort to his master, and the ornament of a circle composed of men not only well capable of appreciating, but also in the habit of substantially rewarding respectability of character and keenness displayed in their service. But if a Huntsman is a low-lived, careless, gossiping, drinking, grinding fellow, seeking only to feather his own nest, and that in the shortest possible time, he will be a torment to himself and everybody about him; and when he loses his place, which he most likely very soon will, he will find his character so blown, that the mere mention of his name to any other master will insure him a polite answer that he has no occasion for his services. A pack of hounds without a good Huntsman are very much like a fiddle without a stick.

Despite, however, what we have said about the liberality of sportsmen to huntsmen and hound servants, we cannot but feel that, considering what they do, the risks they run, and the zeal they show, they are sometimes rather under than over paid. 
Compare them, for instance, with jockeys, who occupy a somewhat similar position in the racing, to what hound servants do in the hunting world. A jockey gets his two or three guineas a race, winning or losing, but if he wins a good stake for his employer, there is no saying to what extent the delightful delirium of the moment may induce a victorious master to go. We have heard that Jem Robinson got a thousand guineas for winning the Leger once, but suppose it was only a hundred, what Huntsman ever got a tithe of that for killing a fox? A race is but a momentary spasm compared to a hard run over a difficult country, and the dangers of the one are nothing compared to those of the other, but the produce is oftentimes very different. It is not, however, for the purpose of making servants dissatisfied with their places that we have made these observations; on the contrary, we will remind them that hunting, unlike racing, does not admit of money making, consequently they must put down as no small part of their perquisites the enjoyment they themselves derive from the pleasures of the chase, and remember that though some jockeys may get large presents, yet their employment is precarious, and that it is better to have the certainty of a Huntsman's wages than the capricious windfalls of the uncertain goddess, Fortune; but we alluded to their pecuniary position for the purpose of encouraging the custom that has now almost entirely superseded the old one of capping-namely, that of gentlemen making huntsmen and hound servants presents apart from their wages. Capping certainly had its advantages, but perhaps its disadvantages preponderated. It added interest to energy, and perhaps spurred what might have been otherwise indolent men into activity, but it encouraged mobbing and bag foxhunting, which are both highly inimical to the chase. It is not killing the animal that constitutes the charm of foxhunting, 
but it is matching the vigour, boldness, and cunning of a wily animal with the faculties and sagacities of others; putting them on fair terms as it were, and trying which has the best of it. Mr. Smith says, in his "Diary of a Huntsman," that there are foxes that can beat any hounds if they have time to prepare themselves, and have a fair start.

Another recommendation that capping on the death had, was, that it was done at a time when men's hearts were open to the generous impulsesthey had just partaken of the highest enjoyment they know, and, when an Englishman's heart is fairly moved, it always finds vent through his pocket-hole. The sportsman was carried away by the enthusiasm of the moment, and the hand went in almost naturally. Let him cool, let the cap be next week, and it will be very like paying a heavy doctor's bill a year after a recovery, though we would gladly have discharged it at the end of the illness. Some people cannot resist capping as it is. Old Pigskin's hand, for instance, dives into his drabs as naturally as can be at the end of a good run, and Piggy's liberality leads us to say a few words on the tax-gathering style of collecting. In some hunts, busy men, or men who like to take the credit of others' liberality, institute a sort of compulsory subscription, levying an equal rate on the man who hunts his half-a-dozen days a season, as upon the man who hunts his four or five days a week, dividing what they get with due importance and perhaps some favouritism. This is as bad, or perhaps worse, than the old half-crown system. It takes a guinea from the man who perhaps would give five, and makes a man pay a guinea to whom five shillings is an object. It puts Piggy and Sir Rasper Smashgate on an equality as to means. When lecturing Mrs. Forcemeat Cottonwool on her treatment of our Master at dinner, we advised her to give him credit for knowing his stomach better than she did, and so 
in this case we advise gentlemen to let others be the judges of their own means. Let every man give what is convenient to him, and give at his own time. Never mind if a few dirty scamps do escape. Huntsmen and Whips have too much spirit to wish to take money from such beggars. Let them ride over them the first time they get them down, or give their loose horses a cut instead of catching them.

Capping has been going out of fashion ever since the present century came in. Mr. Corbet, we believe, was the last great Master who allowed it, and with the large fields that attended his hounds, and the many killing runs they had, "Will Barrow and Co." as Nimrod called them, made a good thing of it. Will was a provident man, and when he died $£$ I400 in money was found in old stockings and all sorts of odd places, in boxes where he kept his clothes, besides suits that had never been on, sufficient for a union workhouse. They still pursue the system for the benefit of Lord Hill with the Surrey hounds, and if it is allowable anywhere, it perhaps is in the neighbourhood of London, where chance gentlemen may be out every day, that they may never have the pleasure of seeing again.

The reader will observe that the motto to this paper, taken from Mr. Beckford's "Thoughts upon Hunting," speaks of the Huntsman being "enriched by his greatest pleasure," which in a note he explains to be the field money, collected at the death of a fox. But he goes on to show that capping even then was not universally approved of. "I have heard that a certain duke," writes he, "who allowed no vails to his servants, asked his Huntsman what he generally made of his field money, and gave him what he asked instead of it; this went on very well for some time, till at last the Huntsman desired an audience. 'Your grace,' said he, 'is very generous, and gives me more than ever I gat from field money in my life; yet 
I come to beg a favour of your grace, that you would let me take field money again; for I have not half the pleasure now in killing a fox that I had before." "

After all is said and done, however, we come back to the old opinion that hunting servants are well worthy the consideration of the field, and whether they are remembered in public or private must just remain matter of taste. No master would ever object either way, because it is the best testimony of the field to the adequacy of their servants' services.

We are sorry to say that faithfulness among servants is becoming a rare quality. By faithfulness we mean not only that honesty which forbids their robbing us themselves, but that integrity-that loyalty we may almost call it-which ought to prevent their allowing others to do it without telling. Strange as it may seem, it is no less true, that their consciences seem satisfied with the negative virtue of abstinence themselves. Dangerous virtue! The next step to looking on, is participating, and then comes robbing itself. "Winking" at robbery is the true school of training for New. South Wales.

Whether this indifference to their master's interests is to be attributed to the gad-about habits of the day, or the spread of education and facility of communication by post, or arises from the distance now maintained between masters and servants, is immaterial to the present inquiry. Hunting servants, at all events, have not the latter excuse for their delinquencies; and it certainly does favour the supposition that masters and mistresses are not sufficiently attentive and considerate to their servants, when we find that those who are in constant contact with their masters, enjoying their pleasures and sharing their dangers, imbibe a certain interest and anxiety for them that the mere payment of wages fails to produce. Hunts- 
men are generally intrusted with large sums of money, much of it frequently to be expended in the way of "secret service," and yet we never hear of misappropriation or squandering lavishment. On the contrary, if they do err, it is generally on the side of keenness for their employer. Many excellent stories are told of Williamson, the Duke of Buccleuch's Huntsman, in the way of bargain-driving for his grace. Williamson is a great economist, but such is his dense Scotch stupidity that he cannot understand, because his master is a rich duke, that he ought to pay double for everything he buys. Most servants would think it a self-evident proposition, but Wool can't see it. He drives and screws, and screws and drives, just as if he was bargaining for himself. He had a bad fall a few years since, and, riding about shortly after with his arm in a sling, he encountered a bargain-driving opponent. The man asked him how he was: "Wall," said Will, "I'm batter, thank ye; but I can no get my hand i' my pouch yet." "Gad! ye never could do that," replied the man,

The following is shrewd and characteristic:- "I was paying a bill to a farmer for hay," said Williamson to Nimrod, when that gentleman visited the duke's establishment during his Scotch tour, "nearly fifty pounds, and the farmer insisted upon the odd fourpence halfpenny. I gave him it," said he, with pleasure, "because it showed I had bought the hay worth the money." Williamson farmed the Lothian lands during the Duke of Buccleuch's minority, publishing an annual statement of the disbursements, and he is considered a great authority on all points of useful economy. Going to market with ready money and attention to trifles, is, he says, where the great sarings are effected. Talking of meal, "I know a gentleman," said he to Nimrod, "who never returns the empty sacks. Was there ever such a thing heard of," continued he, with a strong emphasis on his 
words, "was there ever such a thing heard of as a person not returning the empty sacks?" An amusing circumstance occurred connected with Williamson's ideas of practical economy. Being a true promoter of hunting, and consequently anxious to enlist followers by making it as cheap as possible, he wrote a paper, showing where great savings might be effected in many of the indispensable articles of stable use-clothes, saddles, bridles, physic, etc. and sent it to a London periodical. The cockney subeditor got hold of it, and most unceremoniously condemned it, recommending the author, in his notice to correspondents, "to forward a copy of it to the Chancellor of the Exchequer, headed 'Hints for a Budget." " He doubtless thought his correspondent was some puffing tradesman, instead of the "King of Scotch servants," as Lord Kintore christened Williamson. So much for people deciding upon what they don't understand.

Williamson's situation, perhaps, can hardly be called servitude, but his example is not the less valuable on that account. He receives the duke's money, and every man who accepts the wages of hire enters into an implied contract that he will protect and do the best he can for his employer. Williamson's view of the matter was pithily expressed in the following observation:- "I found the duke rich," said he, "and I wish to leave him so."

Scotch servants, we are almost inclined to think, are more faithful in a general way than English ones. Whether there is something about mountainous countries that draws the affections and binds parties in stronger union we know not; but the same may be observed of the Swiss. Spite of all the contamination of English manners, and the corruption of English gold, the Swiss, as a nation, are eminently faithful. The Scotch, we believe, are kinder-more attentive, at least-to their servants than the English. 
They treat them more as friends and companions. There is one thing to be said, that the Scotch do not often encumber themselves with the useless, overgrown, establishments that: some English think necessary for maintaining their dignity, as they call it, consequently the attention that would cut up very small among many, makes a handsome dividend to those servants that are really wanted. Another thing is, that in large establishments notice or attention to one more than another only makes jealousy and

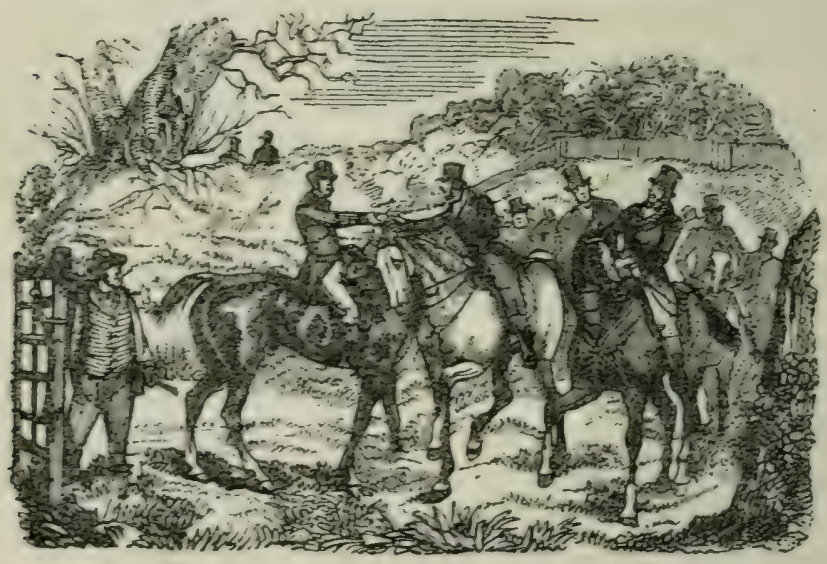

mischief among those who are omitted. These points, however, bear more upon the general question of "servants" than the particular class under consideration.

We commenced this sketch by placing Huntsmen and kennel servants at the head of all others, and as Huntsmen ride first, we presume they would walk first in a procession. If, for instance, Williamson was to be crowned King of Scotch servants, the Earl Marshal would most likely arrange them someway thus :- 


\section{THE HUNTSMAN}

His Majesty Kirg William the Fifth.

Huntsmen.

Butlers.

Valets (and such like cattle).

Eldest sons of Huntsmen.

Whips.

Jeams Plush's.

Fat Coachmen.

Stud Grooms in cut-aways.

Younger sons of Huntsmen.

Eldest sons of Whips.

Grooms, \&c. \&c. 


\section{CHAPTER VII}

\section{THE WHIPPER-IN}

"High o"er thy" head wave thy resounding whip."

SOMERVILLE.

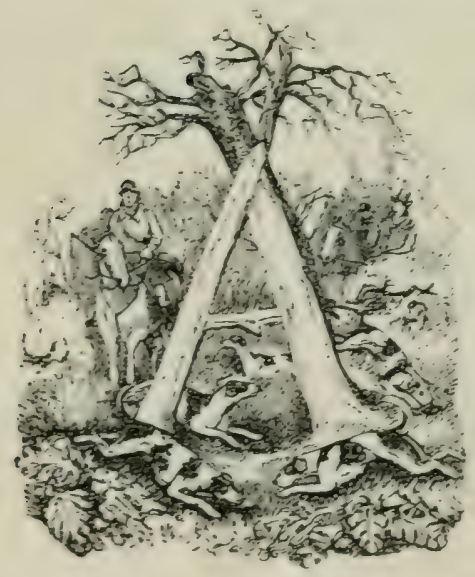

VERACIOUS French gentleman, writing on England, observed that we were a cruel, melancholy nation, for in all parts of London he saw written up, "Horses taken in to bait," and "Funerals performed here." Doubtless the same observing traveller would assert that people keep hounds, and servants to do nothing but whip them. The name, "Whipper-in," certainly favours the supposition, at all events as much as the sign-boards did the conclusions Johnny Crapaud drew from them. Indeed others than Frenchmen might be of that opinion, especially if they heard the noisy, clamorous ratings that sometimes attend a half civilized scratch pack. There is nothing, perhaps, so distinguishing as the silent quiet manner of the well-appointed, welldisciplined establishment, and the roaring, cut-theminto-ribbons style of the omnium gatherum, refuse, tear away, tear-'em up town pack. 
Before railway advertisements increased and multiplied our advertising sheets, newspaper editors used generally, in the dulness of autumnal times, to enlarge a leopard or tiger from the caravan of some travelling showman, which, while it afforded a fine crop of paragraphs, as long as it was at liberty, produced a good stout contradiction at the end, and really we don't think we are going much beyond the mark in saying that a bona fide tiger or leopard would not be much more dangerous than some of these enlarged canine bedlams, called scratch packs.

Beckford relates how a kennelled pack once ate up their Huntsman-nothing but the unfortunate man's buttons being found to account for him-and we have seen animals scouring the country that seemed equal to anything - anything, from a "helephant down to a hearwig," as the dancing-master Huntsman, to the short-lived Fulham harriers, said of his. A man that has never tried his hand with foxhounds has not the slightest conception of the undertaking. He sees forty or fifty couple of great strapping, high-conditioned animals, all as docile and obedient as lapdogs-apparently rather inert than otherwise-and he very likely fancies that listlessness is their characteristic, that they are a sort of canine calves, and that anybody can manage them. Little as hounds are attended to in the field, it must have struck even the most casual observer what totally different animals they are in kennel and out. In kennel they are easy, indolent, devil-may-care sort of creatures, checked by a word, almost a look, but when their mettle is roused by the scent, what dash, what energy, what life, what determination is called forth. The Huntsman's horn and the Whipper-in's rate are equally disregarded, and "getting at them" is the only chance of stopping them. How small a man feels in a kennel with some fifty or sixty couple, looking and smelling at him, as much as to say, "Pray, what business have you here?" 
How pleasant to stand calculating what proportion of a mouthful a-piece one's carcase would make for the company. A man who has whipped-in to harriers, labours under much the same disadvantage that the man does who has hunted them; he is ignorant of the discipline indispensable for foxhounds. Instead of giving a hound one of those hearty good hidings and ratings that makes him tremble at his voice, he is always flopping and skutching, sometimes hitting, sometimes missing, but never making an impression. A foxhound requires a tremendous hiding. Let not the French historian, or the Society for the Suppression of Cruelty to Animals, jump at the assertion. It is mercy in the end, most likely saving the animal from the halter. We have seen a sheep worrier so licked, that he could hardly crawl out of his kennel, and instead of attacking sheep again, he was afraid to look one in the face. After one of these sound flagellations, a hound running riot will stop as if shot, at the sound of the voice that accompanied the administration of the medicine. Of course these hearty hidings are only for flagrant faults-sheepworrying, deer-hunting, poultry-killing, obstinacy, and so on. All young hounds will riot occasionally-a great thumping hare starting up under their noses is enough to lead any one astray, and it is in the checking and stopping that the discipline or nondiscipline of an establishment is shown. Some fellows will set to, roaring and riding, and cracking their whips, making confusion worse confounded, while others just trot quietly on till they near the delinquent, when dropping his name heartily into his ear, followed by a crack of the whip, if the receipt of the halloo is not acknowledged, they will check his unlicensed career, and bring him skulking back to the pack. Some let them have their riot out, especially when the old hounds are steady, and then shame the young ones on their return. Beckford 


\section{THE WHIPPER-IN}

thought it as well, provided they did not get blood.

Some hounds are desperately headstrong, and know the advantage of having a high wall, coped with mortar and dashed with broken bottles, between them and the man that is rating them. For them, Beckford says, "My general orders to my Whippersin are, if, when he rate a hound, the hound does not mind him, to take him up immediately and give him a severe flogging. Whippers-in are too apt to continue rating, even when they find that rating will not avail. There is but one way to stop such hounds, which is to get to the heads of them. I also tell him never on any account to strike a hound, unless the hound be at the same time sensible what it is for. What think you of the Whipper-in," asks he, "who struck the hound as he was going to cover, because he was likely to be noisy afterwards, saying, "You will be noisy enough by and by, I warrant you'?"

When discussing the "Huntsman" we related a misfortune attending a scratch pack Huntsman, or more properly "horn-blower," with a furze bush and a flock of sheep, and in looking into Mr. Vyner's book we find a similar case recorded of young hounds at home:-

"I once knew an instance," says he, "of a lot of wild young hounds being mored into a field adjoining the kennel where they were kept, and where a longtailed black pony was grazing, attended by the feeder alone; from wantonness one of the hounds bayed at the pony, which induced another to do the same, and the pony to declare his approbation or disapprobation by repeated snorting and caprioles; the main body concluded it was a signal for a rush, when away went the little horse over a fence into the adjoining lane, and away went the hounds full cry, to the dismay of the feeder and the rest of the establishment, who were so suddenly summoned by the music of the 
pack; however, to conclude my story, they were not stopped until they ran the pony five miles, but without any further damage to any of the party excepting sowing the seeds of irrevocable wildness whenever an opportunity might offer itself."

All packs, however, must have a beginning, and the following may afford consolation to Masters of newly set up ones:-

"There is an old story told," says Mr. Vyner, "of the Beaufort hounds, when that pack was being first formed many years ago. A new draft of hounds which had arrived on the previous day were let out into the paddock to be inspected, when they commenced running the crows, which frequently fly skimming along close to the ground in windy weather; and, as the old kennelman who had the care of them declared, that he believed they would have never been stopped, if they had not, by the blessing of God, changed for a jackass."

But to the Whip-

The oftener find a "tool" of a Whip than a "tool" of a Huntsman-perhaps because they have not so many opportunities of exposing themselves as Huntsmen, or perhaps because IThip "tools" are blighted in the flower of whipper-in-hood, and never have a chance of blooming into Huntsmen. We have had a letter from a friend, informing us that the "cake" of a Huntsman is described, who used to exclaim in bewilderment on coming up at a check, "Ah dear, whichiver way can he have gone?"_which way do you think he has gone, Mr. Brown?" - "which way do you, Mr. Green?" -had an ornament of a Whip, who never by any chance rode over a fence, and the genius having chased a hound to the confines of a field would sit craning and cracking his whip, hallooing, "Get away, hound! get away'!" the hound, of course, pursuing the same vagaries in the next field as he had done in the one from which he had been 
chased, until interrupted by our friend again cutting round, full grin, at the gate, and repeating the same farce over again. We have seen non-riding Huntsmen do not amiss, but a non-riding Whip will never do. Indeed, we know a gentleman, an ex-Master of Hounds, who says that "riding in a Huntsman" and "being a good shot in a Gamekeeper" are of the least consequence. If the keeper can hit a hawk sitting, he says it is enough for him, and that "brains, a cool judgment, a good temper, and a good constitution" are the indispensable ingredients for a Huntsman. Riding, he adds, is his least recommendation.

But to the Whip again. Here is Mr. Beckford's opinion of what a Whipper-in ought to be:-

"With regard to the Whipper-in," writes he, "as you keep two of them (and no pack of fox hounds is complete without) the first may be considered as a second Huntsman, and should have nearly the same qualities. It is necessary besides, that he should be attentive and obedient to the Huntsman; and as his horse will probably have most to do, the lighter he is the better; though, if he be a good horseman, the objection of his weight will be sufficiently overbalanced. He must not be conceited. I had one formerly, who, instead of stopping hounds as he ought, would try to kill a fox by himself. This fault is unpardonable; he should always maintain to the Huntsman's holloo, and stop such hounds as divide from it. When stopped, he should get forward with them after the Huntsman."

It is ludicrous, but lamentable to sport, to witness a contest between a Huntsman and Whip for supremacy. We remember travelling through Leicestershire some years ago, when the guard and coachman of the mail got to loggerheads on that point, and it ended in the stoppage of the vehicle until the passengers interfered. The coachman found 
fault with the guard about something-perhaps having been too long over his changing drop-when the guard repudiated his interference, desiring him to "go on and make up lost time-for that the coachman was his servant." "Your servant!" exclaimed Jehu, pulling his horses up into a walk; "whose servant am I now, think you?" added he, grinning over his shoulder. So they went on for a mile or more, the coachman pulling up as often as the guard gave his "his servant" orders to go on. Much such a scene occurs in the hunting field, when Whips and Huntsmen have not settled that point any better than our coachman and guard had.

Beckford lays down the law on the point very ably :-

"The Whip," writes he, "must always be contented to act an under-part, except when circumstances may require that he should act otherwise ; and the moment they cease, he must not fail to resume his former station; you have heard me say, that when there is much riot, I prefer an excellent Whipper-in to an excellent Huntsman. The opinion, I believe, is new ; I must therefore endeavour to explain it. My meaning is this-that I think I should have better sport, and kill more foxes with a moderate Huntsman, and an excellent Whipper-in, than with the best of Huntsmen without such an assistant. You will say, perhaps, that a good Huntsman will make a good Whipper-in; not such, however, as I mean; his talent must be born with him. My reasons are, that good hounds (and bad ones I would not keep) oftener need the one than the other; and genius, which if in a Whipperin, is attended by obedience, his first requisite, can do no hurt; in a Huntsman is a dangerous, though a desirable, quality ; and if not accompanied by a large share of prudence, and I may say humility, will oftentimes spoil your sport, and hurt your hounds."

Mr. Beckford, it should be remembered, was speaking of the requirements of his own country, 
Dorsetshire - a country abounding in riot of all sorts, where the covers are large, and there is a chase full of deer and game. True, as Mr. Vyner observes, in a note to this text, that almost all countries now labour under a similar disadvantage from the unhealthy increase of game preserves; but Dorsetshire, perhaps, is still worse than any, owing to the rather plentiful existence of the little roebuck, which is a sad temptation to hounds at all periods of the chase. Beckford, by no means meant to undervalue abilities in a Huntsman; what he meant to say was, that, situated as he was, he could do better with mediocrity in the Huntsman than in the Whip. Hunting talent was scarce in his day.

He then gives the following instance of how much more a Whip is at liberty to give play to his genius than the Huntsman, who must necessarily follow his hounds:-

"A gentleman told me," writes he, "that he heard the famous Will Dean, when his hounds were running hard in a line with Daventry, from whence they were at that time many miles distant, swear exceedingly at the Whipper-in, saying, 'What business have you here?' The man was amazed at the question; 'Why, don't you knowe', said he, 'and be d-d to you, that the great earth at Daventry is open?' The man got forward, and reached the earth just time enough to see the fox in."

Will Dean, or Deane as some spell it, was originally Huntsman to Mr. Childe, who hunted part of Oxfordshire, and doubtless this scene occurred during that time. Dean was afterwards Huntsman with the late Lord Fitzwilliam, who bought Mr. Childe's hounds in 1769 , and Dean has the credit of introducing the present dashing style of riding to hounds. He was considered a great authority in former times.

Mr. Beckford thus recapitulates his qualification for a Whipper-in :- 
"If," says he, "your Whipper-in be bold and active, be a good and careful horseman, have a good ear and a clear voice-if, as I said, he be a very Mungo, here there and everywhere, having at the same time judgment to distinguish where he can be of most use; if, joined to these, he be above the foolish conceit of killing a fox without the Huntsman, but, on the contrary, be disposed to assist him all he can, he then is a perfect Whipper-in."

Some people fancy because a man is a first-rate Whipper-in, that he must necessarily make a good Huntsman; such is far from the case, at least far from being a necessary consequence. Indeed, on this point, none are more sensible than servants themselves. We have known several first-rate Whips who have declined Huntsmen's places, fearing they might not succeed, and have to retrograde in life, a proceeding that is always disagreeable. The observation of most sportsmen will supply them with instances of first-rate Whips making first-rate failures as Huntsmen; again they will be able to point to Whippers-in, who have shone far more with the horn than they did with the couples.

Still it is a good principle of Mr. Beckford's, who says

"Your first Whipper-in being able to hunt the hounds occasionally, will answer a good purpose; it will keep your Huntsman in order : they are very apt to be impertinent when they think you cannot do without them."

A Whip may come up on an emergency, and do a brilliant thing; but as one swallow does not make a summer, so does not one dashing act make a Huntsman. Some men, doubtless, are born to be Whips, others to be Huntsmen. Upon this point we may vouch the authority of Mr. Delmé Radcliffe, an ex-Master of Foxhounds, and an author to boot:"No one," says he, "could ever have seen old 
Tom Ball, formerly Whipper-in to Lord Tavistock, without feeling that he must have been born a Whipper-in. George Mountford would readily admit that, but for Tom, many and many a fox might have escaped his skill, which fell a rictim to Old Ball's sagacity, his knowlege of the animal and his line. Patiently he would sit by a covert side, where, by his ow'n line, he had arrived about as soon as the sinking fox; there would he view, perhaps, a brace or more away, without the motion of a muscle, till his practised eye would recognise the hunted fox, and then would blithe Echo and other wood nymphs be startled by the scream which would resound his knell, and, like the war-cry of the ancients, would reanimate his pursuers with certainty of conquest."

Another very able writer-indeed we think about the best we know on the real essence of hunting, scent and trusting to hounds - who used to write in the "New Sporting Magazine" under the signature of "Thistlewhipper," also bears testimony to the importance of a good Whipper-in, and to the superiority of Tom Ball in that line:-

"I am decidedly of opinion," writes he, "that the success of a pack of foxhounds is more dependant on the exertions of a good Whipper-in than on the Huntsman, and that a North American Indian would be excellent materiel to form one. How often have I witnessed Wells, the Oakley Huntsman, when his hounds were approaching a cover in which they were likely to change, take off his cap, and turn his ear to catch Tom Ball's holloa on the other side, and when he heard it, dash to the head of his hounds, catch hold of them, and gallop round to it."

This gentleman "Thistlewhipper," if we mistake not, was the author of the "Life of a Foxhound," published in the "Old Sporting Magazine."

No one can read his papers without feeling that they are the productions of a real sportsman, a real 
hunter, which is, perhaps, a more determining appellation than that of "sportsman," which, with "sporting man," may be assumed alike by the foxhunter and the thimble-rigger. Being an observing man himself, "Thistlewhipper" noted observation in others. Take the following as an instance :-

"To show how much more observant of little things some men are than others," writes he, "I was standing with about twenty men in a riding, while the hounds were drawing and had drawn a great part of the wood. 'No fox here to-day,' said one. 'Yes, there is a fox moving in that young plantation,' said another, 'and you will see him cross,' and two minutes after he did. There was a universal exclamation, 'How did you know a fox was there?' 'While you were talking,' said he, 'I heard a cock pheasant "ceck up" three or four times, evidently alarmed." "

How beautifully that fact corroborates Beckford's observation, that when you see two men in conversation at the cover side, you may safely infer that one at least knows nothing of what he is out for.

All practical men agree in the necessity of a Huntsman being efficiently supported by his Whippersin. Mr. Vyner, in his "Notitia Venatica," says :-

"Nothing will be found to be of greater importance in the well-conducting of operations than steadiness and persevering exertions on the part of the Whippersin; servants of that description are quite as difficult to meet with as a first-rate Huntsman; a Master, who 'puts up' a booby of a groom, merely because he can ride young horses and scream like a fish-woman, must never expect to see his hounds anything else than wild and vicious in their drawing, and heedless and unhandy in their attention to the Huntsman when casting."

Mr. Smith, in his "Diary of a Huntsman," says :-

"To be a Whipper-in requires both a good eye and a good ear; but the greatest qualification for 
one is, that he should be free from conceit, so that he will consider it right to obey the Huntsman most implicitly, whether he thinks him right or wrong, and not hesitate, but at once instantly do what is required; then he does his duty, but not till then."

Mr. Smith is of the same opinion as Mr. Beckford as to the importance of a clever Whipper-in, and says that men who have hunted their own hounds have often felt a wish to become Whippers-in, knowing, as they do, that it is possible for a good Whipper-in to do more towards the sport most days than the Huntsman. The thing, he says, is to find a man who does not wish to save himself, and he adds, if the Whip is really fond of the sport he never will.

Upon this point, however, we may observe that the greatest keenness may be subdued by work, and that the difference between a gentleman's keenness and a servant's keenness is, that the gentleman's work is voluntary, but the servant's work is compulsory; gentlemen can go or stay at home, as the humour seizes them, but servants cannot. Even on the wildest and most unlikely days, some people will turn up at the appointed meet.

Mr. Smith says, "A Whipper-in should not ride as if he was riding for amusement or credit, but should have his eye to the hounds without distressing his horse, which is a great recommendation to every Master of Hounds. The greatest fools ride the hardest generally; the proof of their being so, is, that they forget they must go on till night, but men who hunt with hounds can go home when they please. A proof of a clever Whipper-in is, that he is always up at a check, without ever being seen in front, except by accident, and no one else there ; but it is his duty to hold in, and by that means he has always something left in his horse, when others are beaten. There are Whippers-in now going who are never seen in a quick thing, and yet are never missed, 
because they are always up when wanted. Who looks for a Whipper-in except then? He does not hunt the fox."

It has always appeared to us, in our casual observation of hounds and different establishments, that servants - Whippers-in in particular - do not give that delightful animal, the hound, due credit for the extraordinary sagacity it possesses. They treat them too much like cattle or flocks of sheep. There is no animal so grateful for kindness, so sensible of injury or reproach as the dog. We often think a London dray-horse possesses far more sense than the great two-legged, plush-breeched buffer on the flags, whose whip point dangles in our eyes. We should be sorry to say the same of hounds and their attendants; but we should like to see a little more reasoning power, and a little less whip-cord used in some hunting establishments-to hear men talking to their hounds instead of rating them.

It has been well said that no animals take their character from their master so much as hounds do from their Huntsman. If the Huntsman is wild, noisy, or nervous, so will his hounds be; if steady, quick, and quiet, he may rely upon it that his pack will be the same.

The same gentleman ${ }^{1}$ who made that observation gives the following judicious advice to Whippers-in :-

"In going through riot, let not the hounds be driven in a heap under their Huntsman's horse, and indiscriminately rated without reason, as is too often the case; but, on the contrary, let the Huntsman seem carelessly to trust them, at a certain distance from him, to take their own way, with the simple precaution of having his men a little wide on either flank; he will then see which hound is to be trusted and which not, and if riot is begun, his men are

1 "Skim," in the "New Sporting Magazine," describing the Hon. Grantley Berkeley's system of management. 
rightly placed to check it, with the further advantage of knowing and rating the hound that offends, instead of chiding indiscriminately. If hounds are driven under their Huntsman's horse when approaching riot, they will pass it by without looking it in the face, noticing it no more than they would if a hare were turned down in their kennel while the men stood by with their whips. Such treatment cannot make hounds steady; on the contrary, they have sense enough to know when they are out of your reach,

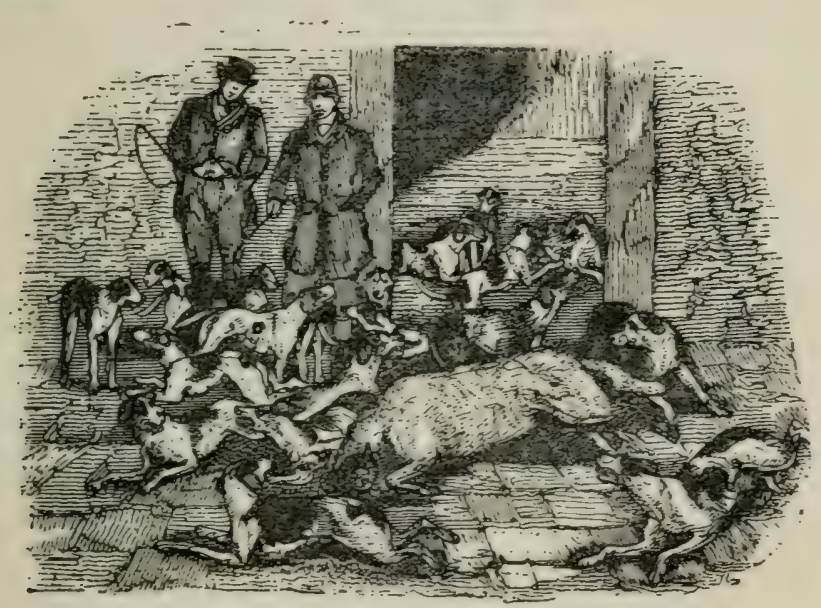

and, like boys from school, on the sudden removal of unnatural restraint, they are the more inclined to join in any riot that may offer. A rate when given at an improper time does more harm than good; it disgusts your honest hound-it shies and prevents from hunting your timid one; and it is treated with contempt by those of another character, who may at some future time deserve it."

Mr. Beckford gives an admirable illustration of the absurdity of supposing that because hounds refrain from mischief when their attendants are by, that they are necessarily steady in their absence. A friend 
of his whose hounds were troubled with the unfortunate propensity of killing their own mutton, bethought him of turning a ram into the kennel among the hounds. Vigorously the old gentleman laid about him with his horns, and patiently the hounds bore it, and after witnessing a good deal of the fun the master and servants retired, leaving the ram apparently master of the kennel. Returning in about an hour's time to show a friend what an admirable receipt he had discovered for sheep-worriers, the master found that the hounds had eaten the old ram up in his absence, and having filled their bellies had retired to their benches. 


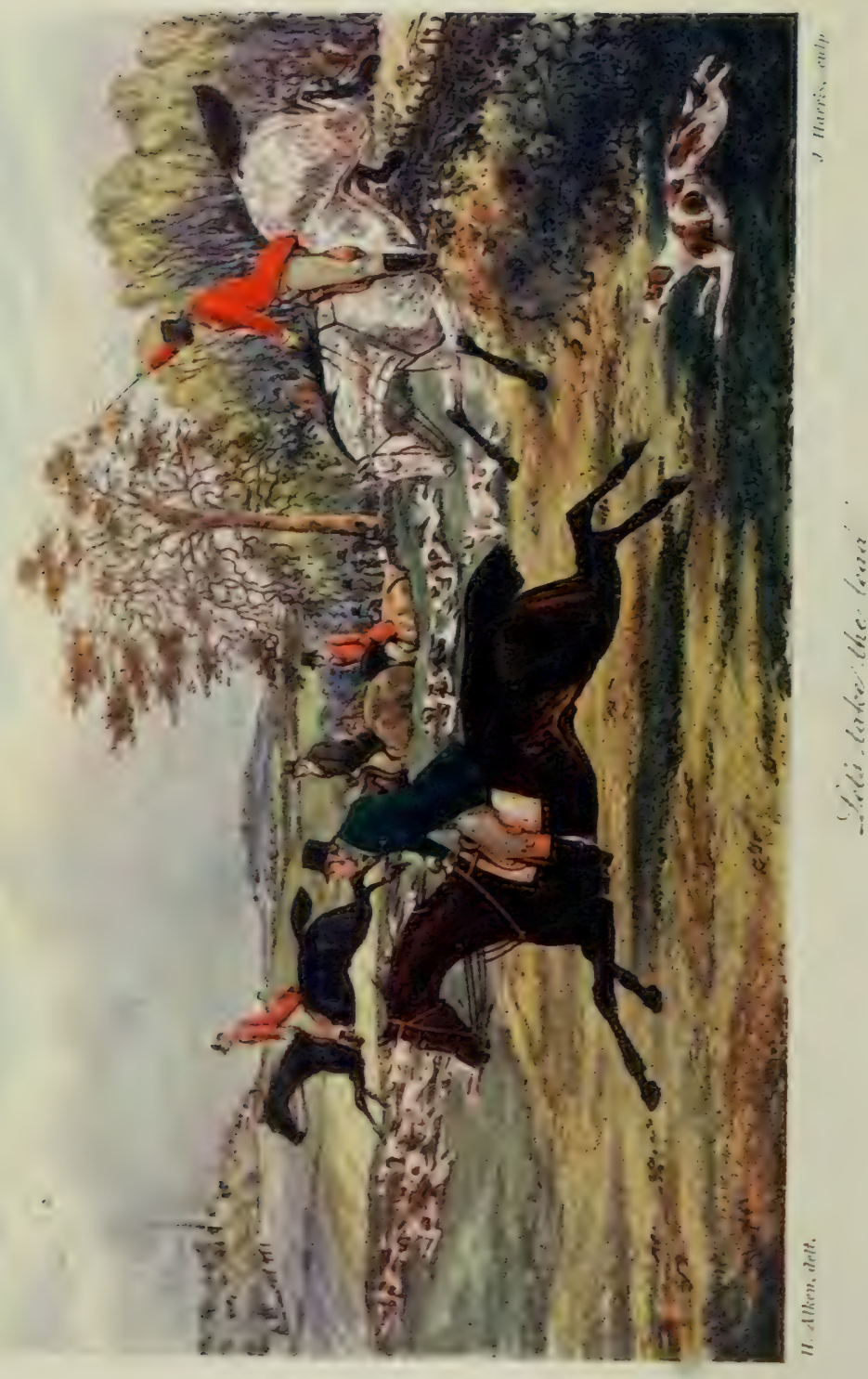




\section{CHAPTER VIII}

\section{THE WHIPPER-IN-concluded}

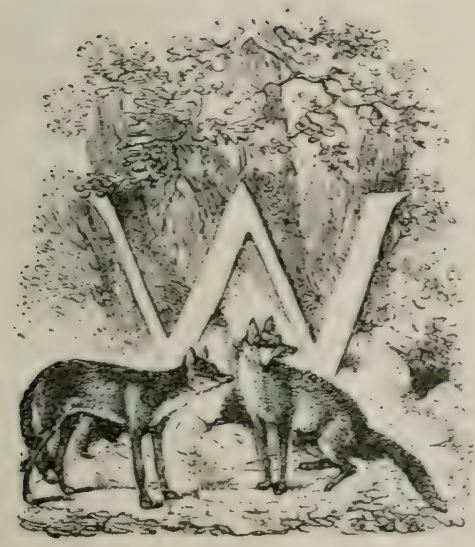

HIPPERS-IN, like railway passengers, may be divided into three classes ; first, the Huntsman Whipper-in; secondly, the regular Whipper-in ; thirdly, the second Whipper-in.

The Huntsman IVhipper-in is to be found in the establishments of gentlemen hunting their own hounds, as Shirley was with Mr. Assheton Smith and afterwards with Sir Richard Sutton, Jack Stevens with Mr. Osbaldeston, Charles Treadwell with Mr. Smith, Hogg with Lord Elcho, and so on.

Huntsmen Whippers-in have difficult cards to play, having to change from Whips to Huntsmen at as short notice as the harlequin in a pantomime, and the worst of it is, they are expected to change the feelings of the hounds as quickly, and to draw an:mals to them in the security of enthusiastic confidence that for weeks and months, perhaps, they have been chasing and driving away. In this respect they have a worse chance than the Gentleman-Huntsman who 
never feeds his hounds, for he at all events does not lick them, and an animal remembers a blow much longer than he does a bellyful of meat.

In addition to this, the Huntsman Whipper-in generally has the pack pawned off upon him, under disadvantageous circumstances-during a hurricane perhaps-or at some out of the way, or interminable woodland meet, or during doubtful, changing, frost catching weather. Of all trials, however, that of wind is the worst. "Take not out your hounds in a very windy or bad day," says Beckford, and hundreds of Masters and servants must have echoed the sentiment.

A Huntsman Whipper-in has not a fair chance under such circumstances, and if we were a Gentleman-Huntsman, and thought the day too windy to go out ourself, we would keep the hounds at home rather than risk an accident by sending them out in such critical times, different to what they usually go. IVind is the very deuce and all in hunting. Fancy being pinned, as we have been, horse and all, on the top of a hill, coat flaps flying out, one hand grasping the hat, the other the reins, with the horse snorting and sticking his feet into the ground for fear of being blown over, and then let a man ask himself if that is pleasure. Pleasure! We would rather pick oakum or work the treadmill under cover.

"On windy days, or such as are not likely to afford any scent for hounds, it is better, I think," says Beckford, "to send the hounds to be exercised on the turnpike-road; it will do them less harm than nunting with them might do, and more good than if they were to remain confined in their kennel; for though nothing makes hounds so handy as taking them out often, nothing inclines them so much to riot as taking them out to hunt when there is little or no scent, and particularly on windy days, when they cannot hear one another." 


\section{THE WHIPPER-IN}

Yet these are the sort of days on which Huntsmen Whippers-in have to exercise their talent, and upon which hasty and thoughtless men ground their opinions. Many people prefer finding fault to praising. They think it shows acuteness on their part.

Again, another disadvantage some Huntsmen Whippers-in labour under, is having the pack assigned under difficult circumstances. Many GentlemenHuntsmen can manceuvre a pack about Salisbury Plain, who would yet be uncommonly glad to get rid of them if they got into the "Crick" country. ${ }^{1}$ Then the Huntsman Whipper-in gets them until the diffculties are past.

We are all great judges of hunting; horses and hunting everybody understands; and the appearance of the Huntsman Whipper-in, in the character of Huntsman, of course throws wide the gates of critical observation. We have many a laugh in our widelymade sleeve at the contrariety of opinion about the same man, and the oracular decision with which each is delivered. If the Master is a favourite with the speaker, then he is the man, and poor Tom isn't fit to hold a candle to him ; but if the Master doesn't stand "A I," as they say at Lloyd's, then Tom is the man, and the speaker only hopes the Master may not return on this side of Christmas. In hunting, as in other things, the medium is seldom hit: allowances are never made; a man is either a demon or a demigod. What one fool says another repeats, and that is what they call "public opinion"-" They say." How disgusting it is to hear some fellows prating about Huntsmen and Whips. Monkey boys in jackets even think themselves qualified to give an opinion.

Mr. Davis, the celebrated animal painter, and brother to her Majesty's Huntsman, commenced an admirable work a few years since, called the "Hunter's ${ }^{1}$ The most strongly fenced part of Northamptonshire. 
Annual," being a series of beautifully executed engravings of the most celebrated of our hunting establishments, in the various departments of the kennel and the field, accompanied by short biographical notices of the hounds, countries, and men. In speaking of the Burton Hunt, then in the hands of Sir Richard Sutton, Davis gives a capital illustration in the words of a "Huntsman Whipper-in " of the difference between the acts of the master and the acts of the man. "Sir Richard," says Mr. Davis, "hunts his own hounds, but his locum tenens must not be forgotten, the prime, good, old John Shirley, one of nature's noblest works. To John Shirley Sir Richard has trusted all the care and business of the kennel and the discipline of his pack. The hounds are made to his hands; Shirley is nominally and hardworkingly (if we may coin a word) the Huntsman. $\mathrm{He}$ was early initiated into the mysteries and duties of stable and kennel in the service of Thomas Assheton Smith, Esq. and we need not say more to convince that both are well grounded in him. He came to Lincoln with this gentleman, and it was here that Sir Richard knew his worth and abilities as a servant. After he had hunted the hounds for some seasons, it was signified to him that Sir Richard wished to take upon himself that task. His answer was, "Well, Sir Richard, I am glad of it, very glad of it ; now, whatever you do wrong, be it ever so wrong, it will be called bad luck; whenever $I$ met with bad luck, $I$ was called ignorantly wrong - that will be the difference. But go on-you will do it well."

And well Sir Richard has done it. Long may he continue to do it, say we.

Jack Shirley, we may remind our readers, is the Whipper-in described by Nimrod as riding the looseheaded old hunter down a hill in one of the worst fields in Leicestershire-between Tilton and Somerby, abounding with ant hills and deep furrows-the rider 
putting a lash to his whip, with a large open claspknife between his teeth at the time.

Huntsmen Whippers-in are like lieutenant-colonels, they have the full command, except when the colonel is present. The simile, perhaps, is not quite good, for the presence of the colonel is the exception, whereas the absence of the Master is generally so in the hunting field. The seldomer the Master is absent, the greater, of course, the difficulty of the Huntsman Whipper-in when he is. Beckford relates how a Master of Harriers had found out that the use of a Whipper-in was to ride after the hare, and keep her in view as long as he could; and we remember a Gentleman-Huntsman assigning a somewhat similar position to his Huntsman Whipper-in with foxhounds. Some one observing that he wondered the GentlemanHuntsman kept a Huntsman when he did the thing so well himself, and was so constantly out, received for answer, that it was "convenient to have some one to 'blow up' when things went wrong." "Blowing up," however, is more generally the perquisite of the second Whip than the first, he always being younger, and his place more easily supplied. We know "a Master" who used to use the second Whip for the purpose of blowing up the field. When he saw a man do wrong, he would send the Whip to ride within ear-shot of him, and then he would come storming up, reading the riot act to the boy, pretending he had done what the gentleman had done.

Having, however, compared the Huntsman Whipper-in to the colonel of a regiment, we may pursue the military simile, and say, that as in the army the comfort of a subaltern is greatly dependent on the character and disposition of the colonel, so, in the hunting establishment, the comfort of the Whippersin is greatly dependent on the manner and conduct of the Huntsman. Some Huntsmen are desperately coarse and overbearing with their Whips, especially 
their second ones, and then having frightened and bullied their wits out of them, they wonder they are good for nothing. We dropped upon one of these bullying gentry unawares one day-a flash fool, who thought himself fit for anything, but of whose talent the world formed so different an opinion, that he is now out of place-and overheard a rating match that he thought was all between themselves. "Come and ride behind me, and don't be showing off there," said he, with all the importance of a lord-lieutenant, to a poor frightened lad he had stationed at a gorse cover corner, with orders not to move till he told him, an order that the lad had implicitly obeyed, but had unfortunately attracted a group of children, who, we suppose, the Huntsman thought would have been much better employed in looking at him. "Like master like man," is a very true saying, and in no instance more strongly exemplified than in Huntsmen and field servants. If the Master is a coarse, swearing, bullying fellow, the man will think it necessary to imitate him. Huntsmen, of all people, take their "cue" from the Master, and they have plenty of opportunity of observing the terms on which eazh sportsman stands with him. Whippers-in take their "cue" from the Huntsman, and much the same manners will be found to reign throughout an establishment. To their credit, however, be it spoken, we scarcely ever met with anything like rudeness or incivility from a hound servant. Some have more manner than others, but they all "mean well." My lord's men are better drilled, have seen how things are done in other establishments, but Mr. Rattlecover's, though they may not "sky scrape" quite so high, would be quite as ready to catch a stray horse, or set a fallen sportsman up on his hind legs. From catching loose horses Huntsmen are always exempt, they must go with their hounds, the office therefore devolves on the Whips, unless some other good 
Samaritan anticipates them. Let the Whips be remembered in the sportsman's "budget." They have no perquisites beyond their pay, and as every little makes a mickle, so a trifle from each sportsman will make a very comfortable addition to their income. Old Sportsmen, we know, will excuse our freedom in mentioning it. They do it already, the hint is for the "young entry" of the season.

But to the duties of second and third class Whippers-in. As yet we have only discussed the office of Huntsman Whipper-in, and glanced more at what the others ought not to do, than at what they ought. We will have recourse to our old friend, Beckford, on the subject.

"When you go from the kennel," says he, "the place of the first Whipper-in is before the hounds; that of the second Whipper-in should be some distance behind them; if not, I doubt if they will be suffered even to empty themselves, let their necessities be ever so great, for as soon as a boy is made a Whipper-in, he fancies he is to whip the hounds whenever he can get at them, whether they deserve it or not."

Another gentleman, whom we quoted before, "Skim," says, "Some second Whippers-in conceive that they are placed behind the hounds on the road to flog up all that stop within their reach, as if they had a cirove of pigs before them; but the whip should never be applied unless for some immediate and decided fault."

Mr. Delmé Radcliffe says :

"The schooling of a pack will much depend upon the efficiency of the Whippers-in. The Huntsman is at this time endeavouring to attach every hound to himself, and will encourage all (particularly the timid hounds) as they are driven up to him by his assistants. A sensible and intelligent Whipper-in will very soon acquire some notions of the peculiar tempers 
and dispositions of different hounds, so essential to a Huntsman; and will not require to be perpetually cautioned against the indiscriminate administration of punishment. For one hound a word may suffice, while others may require as much payment as lawyers before they do anything; with these it must necessarily be not only a word, but a word and a blow, and the blow first; but nothing annoys me more than to see a cut made at a hound in the midst of others guiltless of the cause. It is ten to one but the lash, intended for Vagabond or Guilty, will descend upon Nanager or Blameless, and render others shy to no purpose. The difficulty consists in contriving to awe the resolute without breaking the spirit of the timid."

"Whippers-in, like Huntsmen," writes Mr. Delmé Radcliffe, "must feel a pride in their places, an interest in the credit and reputation of the pack, and thoroughly enjoy the sport, although their labour is not light, but, on the contrary, very arduous, and often harassing and vexatious. Without being able to ride, a man will, probably, not be placed in such a situation; but they should be more than mere riders, they should be active and good horsemen, capable of distinguishing between the use and abuse of the horse intrusted to them."

Some gentlemen assist in turning hounds, some let them alone, lest they may be doing wrong, and get a "blessing" for their trouble; while others console themselves with thinking that it is no business of theirs, and just let them have their fling until a Whipper-in arrives. Of course we would not insult modern sportsmen by supposing that any of them would be acquainted with the name of a hound so as to check him by it as well as by the whip, but in the absence of a Whipper-in there cannot be any harm in one of the field circumrenting a delinquent, and turning him back into cover. Young hands ride 
after hounds instead of riding round them, and the effort is sometimes productive of a fine trial of speed, generally terminating, however, by the intrusion of a fence, through which the hound skulks.

When a Whipper-in is by, however, it is best to let him do the work, because he can very likely effect it by a rate; at all events gentlemen should trust more to their actions than their voices, because the latter are strange to the hounds, but it must be a very dull dog that doesn't understand when a person is mancuvring to lick him. The human voice divine is doubtless a fine popular organ, and perhaps it is a pity that the free use of it does not contribute to the success of the chase, for we never saw a hunting field yet where there was the slightest prospect of a deficiency of noise. We shall never have to import any of that, however. Some few men, however, are so modest or timid, that they are afraid of the sound of their own voices, and if they see a fox break cover, they get into such a delightful state of perturbation, that they don't know what the devil to do, and it perhaps takes them ten minutes or a quarter of an hour before they recover their faculties sufficiently to be able to tell anybody, and even then, they are often in such a nervous state of confusion, that very likely they have forgotten the place. For these gentlemen the hat is the thing. Indeed, a hat high in the air is worth a hundred halloos, especially if the hounds are in cover and don't see it. The Huntsman can then get them quietly out, lay them gently on, and in foxhunting, as in most other things, a good beginning is half the battle. The hounds settle well to the scent, reynard travelling quietly on, perhaps, hears them well in his rear; he then has time to consider which way he will go, and, putting his head straight for his point, gives them a splitter.

Many a fox is lost in the first few minutes. But to the Whip- 
Beckford tells an amusing story of an amateur Whip, who was got rid of with the following politeness:- "A gentleman," says he, "perceiving his hounds to be much confused by the frequent halloos of a stranger, rode up to him, and thanked him with great civility for the trouble he was taking; but at the same time acquainted him that the two men he saw in green coats" (green, the deuce!) "were paid so much by the year on purpose to halloo, it would be needless for him, therefore, to give himself any further trouble."

The first Whipper-in, it seems to be clearly established, is to be an independent genius, capable of thinking and acting for himself, as exemplified in the case of Will Dean and the Daventry earths. The station of the second Whipper-in, says Mr. Beckford, "may be near the Huntsman, for which reason any boy that can halloo and make a whip smack may answer the purpose."

"May be near the Huntsman," and "may answer the purpose," writes our veteran, as though he thought an old head would be better. In truth, though all men must have a beginning, boy Whippers-in are generally as great nuisances as boy butlers. They are like the sham "captain," the London leg proposed to hold the stakes between the Yorkshire yeoman and himself at Doncaster races: "If you doubt me," said the leg, with great apparent hauteur, "my friend, the captain, here, shall hold the money." "But whe hads captin?" asked the wily old Yorkshire tyke, with a shake of the head. "The boy Whipper-in looks after the hounds, but who looks after the boy?"

We once saw a fine scene between a Yorkshire scratch pack Huntsman, and a newly caught yokel of a lad in topboots, a twilled jacket, and jockey cap. They had fallen out in coming to cover, and the lad arrived in the sulks. Scratch packs seldom tarry long at the meet, for the best of all reasons-the hounds 
won't stay, and moving towards the cover, a cur dog took fright, and went away like a fox, with all the pack full cry after him. Yokel sat grinning. "Torn them hooundes," roared the Huntsman. "Torn them thysel!" replied the youth.

That sort of work, however, will not do for our second Whip, who is supposed to belong to a regular establishment. "There is nothing like experience for impressing things properly on people's minds," says Mrr. Delmé Radcliffe, "especially if the consequences are disagreeable"-indeed, according to him, the mind is not the only part susceptible of an impression. In elucidation of this, he relates an anecdote of a "hawbuck," who being monstrously bothered with the word "miracle" that occurred frequently in the course of a sermon, requested an explanation of it from the clergyman after the service was over. The reverend gentleman gave bunch-clod a tremendous kick behind, asking him at the same time if it "hurt him?" "Hurt me!" exclaimed bunch, "you've hurt me most woundily." "Then," replied the clergyman, "it would have been a miracle if I had not." To bring this to bear upon hunting, Mr. Radcliffe recommends practical inconvenience for properly impressing the duties of a second Whipper-in.

"Send your second Whipper-in back," says he, "some miles after hunting, and insist upon his return in good time, not without some hounds that may be missing; he will be for the future more awake to the advantage of minding his business, than by repeated lectures upon the expediency of keeping the pack together. Follow this principle up, if you would have deeds rather than words prevail throughout your establishment." Our Yorkshire friend, if sent on such an errand, would have replied, "seek them thysel."

"The duty of a second Whipper-in," says Skim, "is to send on a hound that hangs, to bring up tail 
hounds, and to mind all that passes in the rear of his Huntsman; and when all are before him together, and clear of the wood, to act as occasion may require." "As occasion may require" is a fine comprehensive phrase, capable of containing anything.

The greatest vice hound servants, whether Huntsmen, first or second Whips, can be guilty of, is that of drinking, and unfortunately it is one to which they are peculiarly exposed. Every person likes to treat them with a glass of something, so what with one glass here and another glass there, they stand a very fair chance of becoming, what country people call, tipplers, that is to say, people who do not get blind drunk, but who are always getting a drop.

"Bless me!" exclaimed old Peter Pigskin, as we were jogging to cover together the other morning, "Bless me! there's Mr. Lapitup drinking a glass of grog at yon public-house door. He's drank fifteen hundred a-year, and he's dry still!"

Gentlemen are not altogether exempt from the charge of encouraging drinking. When hounds meet at their houses, they are very apt to send the butler, or Jeames Plush, out with the brandy-bottle, or something equally potent, and then there's pretty crashing and fiashing, leaping of gates, and larking at rails. It is a bad principle, and a custom that had better be commuted into a goose, or a whole bottle of something at Christmas; after a long ride, or on a cold raw morning, a glass may be all very well. It is against the abuse, and not the use of spirits that we contend.

We do not object to hospitality to servants; far from it, but then we adrocate its exercise at seasonable times. After a good run, no one would object to the frothing tankard flowing round-not even Father Mathew himself, provided that great water saint had first experienced the delightful delirium of a wet shirt, got in a hard ridden run; neither would 


\section{THE WHIPPER-IN}

a glass of something hot and water after a cold wet trashing day be objected to, but rather recommended, but it is indiscriminate cold-blooded drinking that should be avoided. It is a dangerous, a ruinous thing. One glass this year leads to two next, and so they go on till ruin is the result. Servants may take our word for it, that in no station or calling in life will drinking answer. A drunken man is not a man, he is only half a man, sometimes not so much. Hound servants, as we said before, are exposed to wreat temptations. They have frequently to lie from home at night, at inns and public-houses, and we all know the customs of landlords, and the treating habits of tap-rooms. Even in moving about home, exercising hounds, or looking after kennel matters, they are always liable to the offer.

The farmers, the saddlers, the blacksmiths, the bootmakers, all like to give them a drop. They belong to a popular sport, and are popular characters. We once heard an amusing story of Jack Shirley going from Lincolnshire to Mr. Ralph Lambton's, with a draft of hounds, and what was his surprise on getting into the county of Durham (where he had never been before) at finding himself accosted every now and then by the familiar "Jack," and asked what he would drink? He was taken for Jack Winter, Mr. Lambton's Huntsman, whom he greatly resembled.

In the matter of "drink," gentlemen are very apt to treat hound servants as they treat the unfortunate sisters of the parie-debauch them first, and then blame them for being what they are; give them drink, and then abuse them for being drunk. Each man thinks what he himself gives can do no harm; but if hounds met before gentlemen's houses every day they went out, it would be the ruin of half the establishments going. Mr. Vyner comments severely on the vice of drunkenness, and gives the following 
amusing anecdote of what happened with the men belonging to his pack:-

"There can be but one opinion upon the vice of drunkenness in any man," says he, "and the second fault in either a Huntsman or Whipper-in ought to be the last to be overlooked. Many of my readers may, I have no doubt, been disgusted in the course of their lives by such an outrage; but to see a Whipper-in drunk on champagne would be rather a novel sight. I remember once meeting at the house of a jolly good foxhunter 'of the olden time,' who shall be nameless, where he had a most splendid breakfast upon the occasion; and our worthy host, not being content with giving his guests plenty of that exhilarating beverage, absolutely sent a bottle out to the men who were waiting with the hounds upon the lawn: the result may be imagined. Upon remonstrating with the elder of the two upon this most disgraceful occurrence, the answer was, that he was sorry for what had happened, but that he thought there could be no harm in the contents of the bottle, as he had seen a lady drinking some of the same kind through the window just before."

"This man," adds Mr. Vyner, "had but one fault in the world; in other respects he was a most excellent and trustworthy servant, and one of the quickest and best sportsmen I ever saw handle a whip; he had lived twenty years in two of the most noted hunting establishments in England, but gin became his ruin."

Drink is a thing that, sooner or later, shows itself in all men, and, perhaps, in Huntsmen and Whips sooner than in most, through the medium of the voice. There is a huskiness about the voice of the dram-drinker, far removed from the joyful, cheerful note, of the sound, healthy-lunged, sober man; indeed, we sometimes fancy that men's voices sound differently after a "lawn meet," to what they do at 
the ordinary run of the hunting fixtures. After the huskiness comes the broken roice of the old practitioner. We have heard men whose notes have been broken right in two.

It is curious to see how hunting runs in familiesto see how certain names pervade our different hunting establishments-how like begets like, and son succeeds father. Shirley, for instance, has a son Huntsman to Sir John Cope: old Tom Ball, if we mistake not, has one or two Thipper-in sons-one, we know, whipped-in to Mountford, in Leicestershire, in Lord Suffield's time, and we think there was another with the Pytchley, during Mr. Payne's first occupation of the country, if not in Lord Chesterfield's reign. Smith, Lord Yarborough's Huntsman, is great-grandson of the first Huntsman of that name; his father, our readers may remember, had the misfortune to break his neck at a trifling place the very last day of a season.

Mr. Daris, speaking of Smith, the father, in the "Hunter's Annual," where, of him and his two sons, as Whippers-in, capital likenesses are given, says-

"Of the natural requisites for a Huntsman of foxhounds, so much has been said before, and really so much seems to be expected, that a man to shine in this department is one to be chosen out of ten thousand, and then his youth ought to be spent in the education fitting his peculiar line of life. It has been said of Smith, that if schooling had done as much for him as nature had endowed him with, that no situation in life would be too high for his powers. It is highly honourable to him and his family, that he is the third generation filling the office of Huntsman to the Brocklesby Hunt. In ISI6, the Lord Yarborough of that day presented the grandfather of the present Huntsman with a handsome silver cup, capable of holding the liberal quantity of upwards of two quarts, on which was this inscription- ${ }^{6}$ The gift 
of Lord Yarborough to his Huntsman, after having been more than fifty years in his service; made as an acknowledgment of that indefatigable and unremitting attention to the business of his rocation, which may be recommended for a pattern to those who succeed him, and can never be surpassed.'" Of the estimation in which the late one was held by the country, we add a description of the present made to him by his sporting friends:-A large salver, with a bold and richly-embossed edge and border, and a broad chased wreath encircling a plain shield in the centre, on which is engraved - "This salver and a teapot, coffeepot, sugar-basin, and cream-ewer (purchased by subscribers of five shillings each), were presented to Mr. William Smith by his friends and the sportsmen in the Brocklesby Hunt, as a testimony of their high estimation of his propriety of conduct and great ability as a Huntsman: October, I 834." Sebright had a somewhat similar present from the gentlemen and yeomen of Lord Fitzwilliam's Hunt, in 1836 . Sebright is another instance of the passion for hunting running in families. He is the son of a famous Huntsman, and was almost nursed in the kennel. He has gone through all the gradations of service. At fifteen he entered the list of Whips under West, who hunted the old Surrey when Mr. Nevill was Master. He then went to Mr. Osbaldeston, and from him he came to Lord Fitzwilliam. Skinner is a good name. There were three brothers at work with hounds a few years since, all by old Skinner, who was five-and-fifty years with Mr. Meynell. There were four Hills, all Huntsmen or first Whippers-in at the same time. Tom and his brother Peckham in Surrey, Jem in Wiltshire, and Dick in Oxfordshire, or Jem in Oxfordshire and Dick in Wiltshire, we forget which. The Oldacres were all sportsmen, and the name not to be beat; the celebrated old Tom was father of two Huntsmen. 
Treadwell is a good name in the hunting world. There are two brothers who have graduated from Huntsmen-Whipper-in-ships to be regular Huntsmen; one under Mr. Codrington and Mr. Horlock, the other under Mr. Smith of the Craven. Mr. Codrington's Treadwell now hunts Mr. Farquharson's hounds, and has a son a Whipper-in with the Hambledon; Charles, Mr. Smith's one, is now Huntsman with Lord Harewood. Old Tom Rose got young Tom Rose; and, if we mistake not, Tom Wingfield, Mr. Drake's Huntsman, in Oxfordshire, is son of Tom Wingfield, who whipped-in to Raven and Goodall in Leicestershire in Lord Sefton's time. Mr. Drake's Huntsman, Wingfield, has, or had, a Whipper-in of the name of Goodall, very likely a son of Goodall the Huntsman. Tom Leedham, Mr. Meynell Ingram's Huntsman, is or was whipped-in to by his two sons. There is one name, "Jones," that is about extinct in the hunting field. Mr. Meynell had a famous corklegged Whipper-in of that name, who was also a bit of an author, and published some journals of their doings. He was a great rider and a great drinker also. They say he used sometimes to get so drunk that he could not recollect, when he awoke in the morning, where he had left his leg over-night. There was also a Robert Jones, who hunted a joint pack, kept by the late Colonel Wardle and the late Sir Harry Goodricke's father, in Flintshire. The celebrated Tom Crane, afterwards Huntsman to the Fife hounds, came, we believe, from that part of the kingdom, and has left no hunting descendants that we know of. Crane, from all accounts, was a most extraordinary man. It was said of him that one of his eyes was worth two of most other men's, and that his ear was as true as his eye was quick. Crane hunted the Duke of WVellington's hounds during the Peninsular war, and one day in the ardour followed his hounds almost into the enemy's camp. 
Most of these men rose from the ranks, that is to say, from Whipper-in-ships.

John Winter entered life as Pad-Groom under Mr. Ralph Lambton in Leicestershire, in Mr. Meynell's time, and passed through all the gradations of second and first Whip, and Huntsman Whipper-in, when Mr. Lambton hunted the hounds. Dick Foster whipped-in to Lord Foley, in Worcestershire; Will Long whipped-in to Philip Payne with the Duke of Beaufort's; the late Jack Richards, Huntsman to the Badsworth, whipped-in to Sir Bellingham Graham, in the Atherstone country; so did Will Staples, afterwards Huntsman to Sir Rowland Hill-Will was by old Tom Staples, once Huntsman to Lord Middleton. In short, most of our eminent men have filled the subordinate offices of Whipper-in, and risen to eminence by talent and good conduct. Let the rising generation emulate them; but let them remember that talent is of no use without conduct. Above all, let them BEWARE OF THE DRINK.

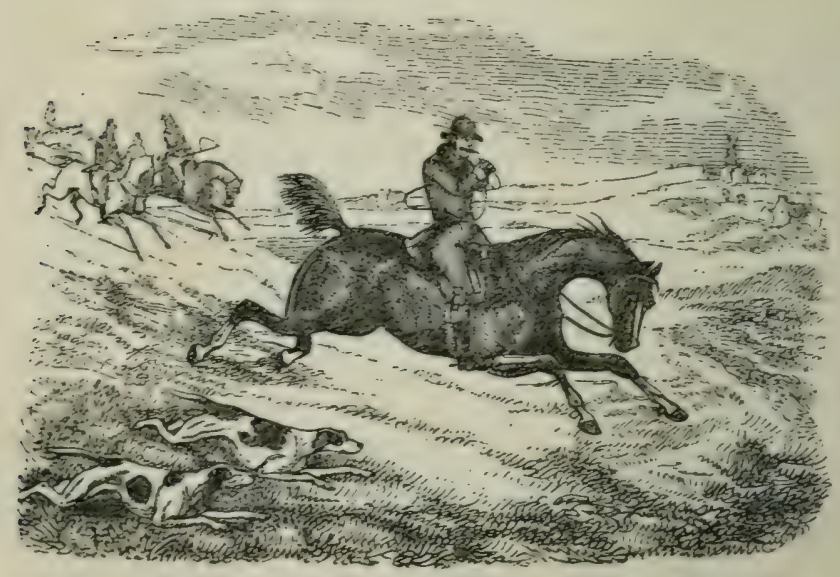




\section{CHAPTER IX}

THE EARTH-STOPPER

"Sis crafty Earth-stoppers in hunters" green drest, Supported poor Tom to 'an earth' made for rest.'

Toy MOODY.

a 10.10

is

ERTAIN things there are we never wished to be -we never wished to be a sailor; we never wished to be an "old Charley;" we never wished to be a great spangled cock ballet dancer at the Opera; we never wished to be Lord Mayor of York; we never wished to be Mr. Green, the ceronaut; we never wished to be a dentist; we never wished to be King of the Cannibal Islands; we never wished to be a surgeon-accoucheur; we never wished to be postmaster of Heligoland; we never wished to be Stunning Joe Banks; and, most certainly, we never wished to be an Earthstopper. An Earth-stopper! oh, no! Of all cold, candle-light, frigid, cheerless, teeth-chattering, armflopping occupations, that of an Earth-stopper assuredly is the most so. When all the world is "snoring," fast asleep, our unfortunate woodland 
watchman has to leave his downy couch and encounter the elements and roughnesses of the thicket. Lord bless us! fancy such a night as last, the rain beating against the casements, the wind howling, and blowing a perfect hurricane: the brooks swelled into torrents, the rivers into seas; and fancy having to leave the warm house, the bright crackling fire, to grope and prowl about the country like a thief in the night time: a man ought to be well paid for such work as that.

Earth-stoppers are of two sorts- the resident Earthstopper, and the head Earth-stopper, or Earth-stopper in Eyre, as the old law books designate the judges of assize. The head Earth-stopper is an officer peculiar to great establishments; he is like the military inspector of a district, and it is his business to go about and see that his subordinates do their duty. In summer he receives and examines into the truth of reported breeds; in winter he sees that the right range of country is properly stopped; and, above all, properly opened. The Earth-stopper only does half his business who only stops the earths; opening them after hunting is quite as important.

Yon weather-beaten old man, in the two-year old cap, and three-year old coat, is the head of the department of our hunt; he is to the Earth-stopping fraternity what the "superintendent" is to the police; he is paid by the year, they by the stop. Old Foxfix, for such is his name, is a varmint looking old fellow, and when the old grey-or rather white-is away from the high conditioned horses of the field, and the new scarlet coats of the men do not throw the old plum colour into the shade, he makes a very respectable appearance. He knows every hillevery rise from which a view of the varmint may be obtained; and often when the chase has lagged, and hopes began to pall, old Foxfix's cap, on the sky line of the horizon, has infused joy into the field below, 
and brought hounds, horses, and men, to his welcome and undoubted halloo.

The Earth-stopper is generally a popular man in the country, and many of them are as good hands at finding their ways into the earths of farmers and gentlemen's houses, as they are at finding the fox earths. Besides ascertaining the breeds and probable number of foxes, they have also to hear evidence as to their ravages, and keep a check on the poultry account. Here they act as middle men between the Master and the hen farmer, and in this department we would advise them to give the cast of the scale in favour of the farmer. Never mind if the hunt does pay for a few more hens and geese than reynard really consumes. Foxhunters pay nothing for field damage, hedging, rail-mending, and so on; and, moreover, the poultry is generally the perquisite of the ladies, to whom foxhunters are always ready to do suit and service. Indeed, were we a Masterwhich had we to make out a catalogue of wishes instead of one of objections-we should place at the head of the list-we should always be glad to hear of a good lot of poultry damage. We should regard the ravages of reynard much as we regard the appetite of our friend Peter Pigskin, who it does our heart good to see feed. The more damage say we the more foxes, at least we would flatter ourselves so, though some ungentlemanly foxes certainly will commit waste as well as proper plunder. These, however, are the shabby dogs of the country, who generally die ignominiously in corer, their distended bellies "with fat capon lined."

In no instance is the popularity or unpopularity of a Master more apparent than in the abundance or scarcity of foxes. The man who can command a country full of foxes without the aid of a superintendent Earth-stopper, resembles a monarch who can trust himself among his people without a body 
guard. There is no criterion-in a hunting country at least-so infallible as a goodly show of foxes. It shows that the farmers and the country people are pleased-rank, wealth, large demesne, will not insure what the single word "popularity" will achieve. Popularity is, in truth, the foundation of foxhunting. It is very true that the sport is popular itself, but it is also equally true that a popular man with moderate means will far outstrip in his show of foxes the richest millionaire who lacks that quality.

Not that we mean to insinuate that keeping a regular Earth-stopper is any sign of want of popularity; on the contrary, we have known some most popular Masters who have always had them, but we say that half a-hundred regular Earth-stoppers will not insure foxes to a Master who is personally offensive or objectionable. Fox-preserving, like voting by ballot, is a good deal matter of conscience. A man promises to "preserve" just as he promises to "vote" for you, but if he keeps his own counsel you cannot detect the contrary. After all is said and done, therefore, popularity is the best fox-finder.

There is something very sporting and picturesque about a fox earth. They are generally in romantic, sequestered, secluded places; in deep ravines, or on the side of woody hills. Their adjuncts are all pure and rural. The clean thrown up sand at the mouth, the projecting rock above, or knarled root supporting its lofty time-honoured oak, with the little accompaniments of bright growing hazel, knotty black thorn, and withered fern or faded heath. It is strange how fox after fox draws to the same spot; what was a breeding earth a century ago is a breeding earth now, and is as notorious to a country as a turnpike gate. How creditable it is to the lower orders that they should be held, as they are, inviolate, at least in all countries where hounds come, or are even expected to come. The man who has killed a fox is quite as 
much an object of execration among the lower orders, as the acred vulpecide is in the higher circles, with the disagreeable addition of moving among men accustomed to speak their minds without the gloss of courtly phraseology. "Who shot the fox?" is an exclamation that has sent many a skulking vagabond out of the public-house, when a group of honest rustics have been exulting over a day's sport. Indeed, the lower orders set an example well worthy the imitation of many who call themselves their superiors in their respect for the fox. They look upon him as a sort of privileged animal. He even seems to shed a sort of lustre over those in any way connected with him. Ask the first people you meet in a village where the constable lives, and they either can't or won't tell you, but ask where the man lives "wot stops the fox earths," and they will not only tell you, but accompany you to the door. This is as it should be, and long may it continue so. It is this that gets Earth-stoppers -it is this that makes men nervous and fidgetty in their beds, lest they oversleep themselves, and very possibly causes them to bolt master reynard's door before he has left the house. They are anxious for the sport themselves, and anxious for the amusement of the country at large. They feel that the honours of the day are greatly dependent on them, and are correspondingly alive to their duties.

Mr. Daniel, in his "Rural Sports," says, "The fox knows how to ensure safety, by providing himself with an asylum, which he either does by dispossessing the badger, or digs the earth himself; in either case it is so contrived as to afford the best security to the inhabitants by being situated under hard ground, the roots of trees, \&c. and is, besides, furnished by the fox with proper outlets, through which he may escape from every quarter; here he retires from pressing dangers, and here brings up his young; so that the fox is not a wanderer, but lives in a settled domestic 
state." Daniel makes him quite a respectable character, a housekeeper in fact, with a back and front door to his residence, though we cannot say we ever saw an earth with such accommodation. In running to ground where rabbits abound, it is not uncommon for reynard to bolt out of one hole while the foxhunting "navies" are busy at another, but those holes are made by the "bunnies," not by the foxes; reynard is there only a lodger. Speaking of his domestic habits, Daniel says further, "The idea of a settled place of abode indicates a singular attention to self; the choice of a situation and of rendering that abode commodious, and of concealing the avenues to it, imply a superior degree of sentiment; the fox is endowed with this quality, and manages it with advantage; he prefers the covers near dwellings, where he listens to the cries of the poultry; in his attacks upon them he chooses the time with judgment, and concealing his road, slips forward with caution, and seldom makes a fruitless expedition." Daniel had not been much of a fox-man, we think, or else the animal must have changed its habits a good deal since his book was written. We have often seen foxes found in covers in the neighbourhood of farmhouses, but we do not remember at this moment ever seeing an earth at all that would be called close to farm buildings. Daniel's book, however, was written forty years ago, since when foxhunting has undergone considerable change, particularly the lodging - we might almost say the domestication of foxes. We have now all sorts of artificial contrivances, from the fagot cover down to Mr. Smith's masonic drain. In Daniel's time, indeed, it seems to have been a " moot" point whether foxes were entitled to protection or not, just as we have heard people contend for the right to shoot persons who have the luck to be outlawed. Daniel says, "The destruction and preservation of foxes are points upon which there is a differ- 
ence of opinion; the law holds out a reward for the death of the animal, to be paid by the churchwardens of every parish, whilst the foxhunters and their friends use all possible exertions to protect the breed and increase their numbers." He then gives the letter of a nobleman to his agent in Leicestershire, desiring the agent to show every accommodation to the tenants who had been friendly to the hunts of "Lord Spencer, the Duke of Rutland, Mr. Meynell, and Lord Stamford." "On the other hand," writes the noble lord, "you will take care and make very particular inquiries into the conduct of those tenants who shall have shown a contrary disposition, by destroying foxes or encouraging others so to do, or otherwise interrupting gentlemen's diversion, and will transmit me their names and places of abode, as it is my absolute determination that such persons shall not be treated with in future by me upon any terms or consideration whatever. I am convinced that landowners, as well as farmers and labourers of every description, if they knew their own interest, would perceive that they owe much of their prosperity to those popular hunts, by the great influx of money that is annually brought into the country; I shall therefore use my utmost endearours to induce all persons of my acquaintance to adopt similar measures; and I am already happy to find that three gentlemen of very extensive landed property in Leicestershire, and on the borders of Northamptonshire, have positively sent, within these few days, similar directions to their stewards, which their tenants will be apprised of before they re-take their farms at next Lady-Day. My sole object is, having the good of the community at heart, as you and all my tenants know that my sporting days have been over some time ago."

That letter is as good now as it was the day it was written.

Having mentioned Mr. Smith's artificial earths or 
drains, we may here quote what he says on the subject of stopping, in his "Diary of a Huntsman."

"Hunting countries," says he, "which abound with fox-earths are very liable to have blank days, according to the usual method of arrangements; for where there are earths, foxes at times will be in them when they are wanted elsewhere, even when the Earth-stoppers do their duty; but the first question to put is, whether it is likely that a man can be depended on to get up long before daylight in the coldest and most dreary part of the winter, to stop a cold earth and leave the warmer clay by his side. It's all very well for men to say "yes!" and that they know they do their duty properly, for they have sent down to ascertain it. Ascertain what? that the earths were stopt before it was light. What matter that? how long before light does a fox go to ground at this time, when it is not light much before eight o'clock, this being three hours later than at other parts of the season; and they are consequently more often stopt after the fox has gone in than before, and a very little ingenuity will extort this fact from an Earth-stopper, that he has often found his stopping removed by a fox scratching out when he has gone to take it out himself next morning, which accounts for many blank days."

Some amusing productions used to be published a few years ago, under the title of "Sporting Almanacks," and assuredly, as far as making sport went, they were rightly named. In them the commencement of hunting used to be fixed as accurately as Horncastle Fair or Doncaster Races. Such a day of September harehunting commenced-such a day of October foxhunting began, without any reference whatever to the seasons. Earth-stopping is dealt with in a similar way by certain sporting compilers-between such an hour and such an hour the Stopper is directed to be 
at his work, without reference to weather, season, localities, moon, or anything, just as if foxes had their dressing and dinner bells, and went to feed with the punctuality of their pursuers. "We may be wrong," as Mr. Meynell used to say, but we take it foxes resemble a gay club living bachelor, much more than a punctual six o'clock family man. They like their chicken, or lamb chops, just at their own time, without the restraint of specified hours. Reynard may have fallen in with something dainty in the middle of the day, and may not feel inclined to turn out on the grand prowl till a later or earlier hour in the morning. He may put his nose out and find it raining, and having neither cloak, macintosh, or clogs, may decide that he is not hungry, or that he has a little something in his larder in the neighbourhood that he can get when the weather improves.

From an hour before midnight, till about three o'clock in the morning, is the prescribed time of the authorities, though should it be moonlight, and reynard hungry, we don't see what is to detain him at home so late. Better, however, to be late than too early, for it is unpleasant, both to fox and followers, to have him in the "lock-up house" when he is wanted at large.

Mr. Smith was an advocate-indeed the inventor of the system of walling up earths at the beginning of the season, the duties of the Earth-stoppers being to see that the fagots, or whatever the barrier was made of, were not removed until the spring, when the vixens were let in to a lay up. A deduction was made from the pay of a man for each time a fox got to ground in his district.

Mr. Smith, indeed, considers the disadvantages of having earths are so much greater than the advantages, that if every earth in the country were done away with, it would be a benefit to foxhunting, even as respects the breeding of foxes, for the vixens would 
breed above ground in furze, or would find drains which no one knows of.

Colonel Cook published an estimate some years since of the expense of hunting a country, which has been quoted and requoted till we are tired of seeing it, for it has always appeared to us that the expense of hunting one country affords no more clue to the expense of hunting another, than does the management of foxes and fox-earths in one country afford a guide to the management of foxes and fox-earths in another. Almost all countries are now hunted after some fashion or other, and a good thing it is that they are, for it not only keeps men at home, but it affords sport and amusement to many who would otherwise not get out at all, but one country may have too many foxes, while an adjoining, and better one, may be short of them. The better a country is, the greater the trouble, difficulty, and expense of keeping it stocked with foxes. This is self-evident, for the greater the security, the greater the temptation to foxes; hence the necessity of hunting good and bad places alternately, or the foxes will be all huddled together in the bad places. Hills, forests, deans, crags, rocks, are all friendly to foxes, but unfavourable to the progression of the chase. We remember breakfasting with a Master of wiry-haired, rough mountain hounds once, when the servant came in to say that a neighbouring farmer had sent word that he must shoot the fox if the gentleman did not come to hunt him, for that reynard was constantly eyeing his lambs. "Tell him to blaze away," replied the gentleman, adding as the servant left the room, "if there were fewer foxes I should kill more, but the fact is, if I ask a man in this country to stay his hand, he will think he has a claim on me for damage, whereas I hold out that I have a claim on them for keeping down the stock of foxes, besides," continued he, "there are many chances in reynard's favour as it 
is. First of all, it's ten to one that the old blunderbuss will go off; secondly, if it does go off, it's twenty to one but the farmer misses, and the fox will know just as well as him that he has got something in his hand, and will take good care not to let him come within reach." Good logic in the mountains, but not in the vales. Contrast it with the doings in Hertfordshire as described by Mr. Delmé Radcliffe, who truly says that a fox there is worth his weight in gold. Speaking of the fees to keepers he says :-

"In the first place, I condemn the fixed price set upon each day's amusement, the extravagance of the terms upon which hounds leave their kennel, as likely to operate, at some time or other, seriously against bye-days; and as an increase of contingent expense which might well be spared. Secondly, I assert, that with all the good will and support of the nobility, squirearchy, and yeomanry, the Master of Hounds in this, or any other similarly circumstanced country, is virtually at the mercy of Gamekeepers and Earthstoppers. For every fox that is found, from one end of the country to the other, the sum of one sovereign is booked, allowed, and regularly paid. The fees of Earth-stoppers, from half-a-crown to ten or fifteen shillings, according to the number of stops within the province of each, amount on the average to four pounds per diem. Thus, supposing that the sport is limited to the finding of one fox, we start with an expense of five pounds as the smallest tax upon the day, independent of all the inevitable wear and tear. So long as the subordinates have as much interest in foxes as farmers have in their stock or any kind of property, it is not to be wondered that the animal abounds; and it is equally clear that it would be better that they should cost two sovereigns each, than that the stock should be diminished, seeing that there is no medium-that they are, or are not, that they are altogether preserved, or utterly destroyed- 
as there is no such thing as modification in the forms of vulpecide." This is expensive work certainly, but we do not see how it is to be remedied. Foxhunting, without foxes, will never do; there is nothing more disheartening than riding from cover to cover, with the full conviction that each will be a blank. We knew a man who went to an enormous expense with his hounds, but somehow or other, he could not find in his heart to pay his Earth-stoppers properly, consequently the whole outlay-some thousands per annum -was absolutely sacrificed for a paltry saving of a couple of five pound notes, for we really do not suppose the difference between what he did pay, and what he ought, would have amounted to more in the year. "Hertfordshire" does not sound much like hunting, and doubtless this is an extreme case, and one that is not likely ever to become general. In fact, none but a rich country could stand such work. A bad custom, however, is much easier introduced than got rid of, and gentlemen in other countries will do well to take warning by Hertfordshire. The mischief here appears to be the "patent office" of keeper, the fees to Earth-stoppers not being higher than in other countries. Earth-stoppers should be well paid. Theirs is the worst office connected with hunting. A little pettyfogging economy is badly exercised with them.

Mr. Vyner says that in Warwickshire, in 1830 , the Hunt Committee reduced the pay of the Earthstoppers to half, and the result was, what might be expected, in about half the covers " no find."

An occasional "tip" to a keeper is all very weli, but the regularly "booked demand," described by Mr. Delmé Radcliffe, "carries absurdity and inconsistency on the face of it," as exposed by the honourable gentleman himself, who says "that it is done, notwithstanding most of the great game preservers in Hertfordshire have as much or far more 
pleasure in the possession of foxes than of game in their coverts ; therefore it appears somewhat absurd that they should be compelled to become parties to the purchase of them from the very servants whose duty it is to protect them. The Master stipulates with his keeper no less for the protection of the fox than of the pheasant, and yet allows an extraordinary premium to be paid, a prize to be directly awarded to him for the fulfilment of that, in default of which he should, and generally would, be discharged."

Mr. Delmé Radcliffe suggests the following remedy :-

"I would not entirely abolish rewards to keepers," says he, "by way of encouragement in the shape of douceurs at Christmas, or at the end of the season; but I would have no regular charge for finds, nor even regular charges for Earth-stopping, excepting in coverts expressly hired for the purposes of the hunt. There such payments might be a part of the wages of those employed; but I would have the preservation of the foxes, and the stopping of the earths for hunting matters, entirely dependent upon their respective proprietors. I would have every lord of a domain make a point of enforcing his determination to contribute gratuitously all in his power to the noble sport."

A very good resolution, say we; but suppose the said lord is a shooter, how then? Foxhunters are very apt to fancy that every one must favour their sport, but some apparently very friendly people would have no objection to see foxhunting abolished altogether.

"Instead of a regular bill, amounting to from $£$ Io to $\mathrm{I}_{5}$ to be presented by a keeper," writes Mr. Radcliffe, "as the price of his forbearance, in permitting the existence of animals considered obnoxious to game, and, in reality, destructive to the rabbits, 
which are his perquisites, I would have $£_{5}$ the maximum of remuneration. Such a sum might be adequate compensation to any good servant for the trouble of doing his duty, and would be received merely as a token of approbation of the manner in which he discharged it, when the success of his endeavours entitled him to such consideration. There can be no reason why underkeepers, or other labourers, might not as well undertake the earthstopping, on account of their regular employer, as on that of recompense from a separate body."

"It has been always the custom, in Herts," continues our author, "to hold two Earth-stopper feasts, one on each side of the country; the Huntsman presiding: they are attended by all the Gamekeepers, Earth-stoppers, et hoc genus omne, of the districts; the annual expense of both seldom exceeding $E 30$; and they tend to implant, and keep alive, sentiments most desirable to cherish."

Mr. Smith devotes a whole chapter to keepers, between whom and the world at large he seems anxious to do justice.

"There is an old saying," writes he, "give a dog a bad name and hang him,'-which maxim is too often applied to gamekeepers: for there are some who are really friends to foxhunting, and who have more pride in showing foxes with their pheasants, that is in the same covers, than any others can have in showing pheasants without them: innumerable instances can be proved that foxes and pheasants can be had in abundance in the same covers, particularly where there are rabbits: the writer has seen five foxes cross a ride in a cover, and nearly as many hundred pheasants."

In the following, Mr. Smith hits the right nail on the head :-

"The great objection which keepers have to foxes is, that they destroy so great a number of rabbits, which 


\section{THE EARTH-STOPPER}

are the keeper's perquisites, and consequently they are disposed to destroy foxes."

No doubt about it, and therefore the remedy is not to let the keeper have rabbits. Some people will say they won't come without. Won't they, indeed! We know a gentleman who advertised for a keeper, and had thirty applications in one week. Keepers are not like Huntsmen or Whips, men that are difficult to meet with. As Mr. Grantley Berkeley, the great game authority of the day, says, "Any man who can shoot a hawk sitting will do for a keeper."

"It is a difficult thing," adds Mr. Smith, "to know how to act with them; but it is much the wisest plan to treat them civilly, even if they are doubtful, until proofs can be brought against them that they do destroy foxes against their master's will; for there are many keepers most highly respectable men, and indeed, under any circumstances, it is the height of folly to abuse them openly, as is too often done."

Mr. Smith afterwards relates an anecdote of a most righteous keeper, who, being accused of killing cubs, which he offered to take any sized oath he did not, on the act being brought home to him, candidly said, "Well, then, I did do it; for it would be unnatural in me not to kill what I was brought up to do."

We are, however, getting rather off the line, but keepers are so connected with foxes and Earthstoppers, that we could hardly aroid touching upon them. We agree with Mr. Smith that there are many highly respectable men among keepers, men who are really fond of hunting, and we are not sure that in some instances where they are blamed, the fault is with the Earth-stopper. Of course an Earth-stopper cannot "ring" the foxes out at a certain hour, as the bellman does the merchants on the Royal Exchange, and he must just "stop" at the likeliest time for the majority to be roaming; and, if any stay at home 
when they ought to be out, why they must just go without their suppers. Do not, however, let sportsmen condemn a keeper for an occasional blank. Who knows but a fox, finding his earth stopped, may say to himself, "I'll cut my stick; for, if I mistake not, those terrible high bred dogs of Mr. Rattlecover's will be here to-day." It is not attributing too much sagacity to the wily animal to suppose that he will recognise the features that preceded a former discomfiture. Fores are quite as good hands as other animals at discriminating where harm is meant and none-who are their friends and who not. How leisurely a fox disturbed by the sombre dressed shooter trots away, sniffing the air and looking over his shoulder, as much as to say, these bothersome people are not wanting me. He takes them as coolly as the "Artful Dodger" would take a policeman in quest of a comrade with whom he has not been doing "business" lately.

Here is old Foxfix himself, we declare, doing the electric telegraph with his cap, rejoicing the hearts of a now desponding field.

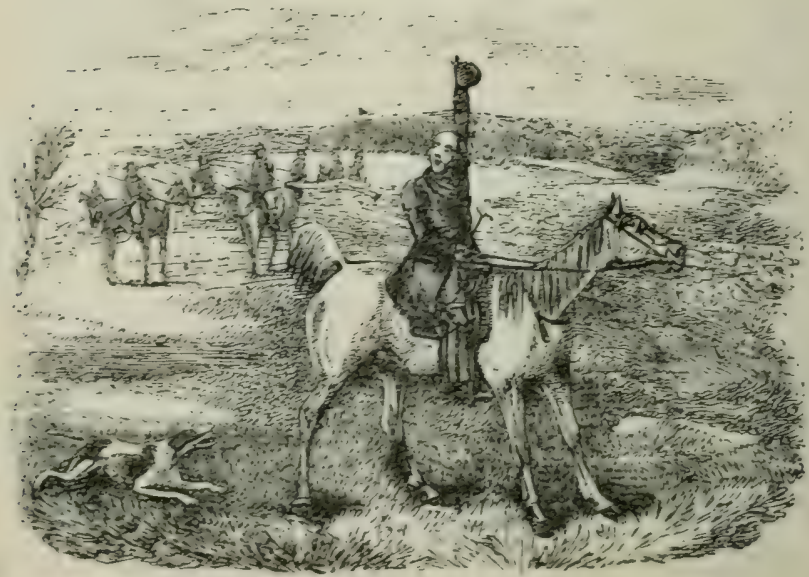




\section{CHAPTER X}

THE GROOM

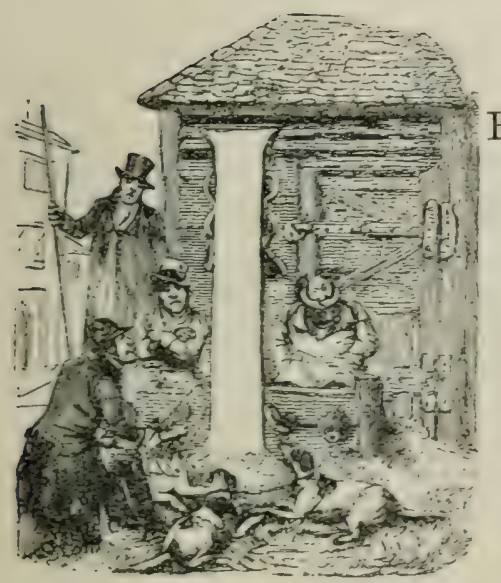

$\mathrm{F}$ half the fellows calling themselves "Grooms" were in their proper places, how well the pigs would be attended to!

Were it not for the inconsistency of the thing, it would say much for the confiding innocence of human nature, and confidence in mankind, that while some men try, and pause, and deliberate, and hesitate, and call in friends, and, lastly, veterinary surgeons, to examine a horse ere they buy him, they yet can hire a Groom with oftentimes no recommendation but the fellow's own. It never seems to strike some men that a horse is a horse, or only half a horse, according to the manner in which he is kept - that you may make one and the same animal two perfectly different creatures, by good grooming and bad; nay, that you may even keep a groggy, half worn out horse on his legs by dint of condition and management. Grooms are as various as geraniums or dahlias - they are of all sorts, from the Stud-Groom of my lord duke, who occasionally condescends to hold a 
stirrup, down to the yokel who looks "arter" old Miss Frowsington's "one oss chay," digs the garden, waits at table, milks the cow, washes the poodle, cleans the parrot's cage, sweethearts the maid, and makes himself generally useless and troublesome. Grooms rank high in the scale of servitude, and though in our fancy sketch of the Earl Marshal's coronation procession we put house servants above them, yet, if we were arranging them, we are not sure but we would place Grooms immediately after Huntsmen and kennel servants. We look upon a Groom as a real useful article in an establishment; in our mind they rank equal with the cook in the domestic department, and, like cooks, are of exceedingly various orders of merit. We can't do without a Groom, any more than we can without a cook; for though in our moments of high-horseish-ness we may swear that we will clean our own horse or cook our own dinner, rather than put up with the impudence of a servant, still it is a feat that no one would like to be constantly repeating. Grooms, therefore, we say, are really useful people, and, like the old story of the king and the basket-maker of our childhood, rank before the ornamental "knights of the napkin" and toilet.

Of course in this our "Analysis of the Hunting Field," the Hunting Groom is the one we have most in our mind's eye, and to him we shall chiefly direct our observations.

A great change we imagine has taken place in the whole style and system of hunting within the last century, and everything appertaining to horses, hounds, country, and riding, has undergone material alteration.

If we take an old map of a county, it looks like a barren plain instead of the divided town dotted populous region of the present day, and though in riding over it we may be told that this is Thisselton 
Moor, or that Wideopen Common, there is nothing to indicate such regions but the name. Moors, open fields, common lands, \&c. are all favourable to hunting, not only as tending to promote the straightforward progression of the chase, but in preventing the honourable contention of arriving first at big leaps ; for it may be observed, that men are never jealous of each other so long as there is no fencing. Our forefathers, therefore, had every chance of being sportsmen; for, besides having no rivalry or emulation among themselves, the lengths of their runs, with the softness of their steeds, tended to make the riders save them at all points. With the exception, too, of perhaps some half-dozen hunts, Mr. Beckford's, Mr. Meynell's, Lord Talbot's, Lord Yarborough's, Lord Fitzwilliams's, and a few others, the majority of the packs were either trencher fed, or only kennelled during the winter: a couple, or so, of hounds, perhaps, being kept at the house of each follower, whose attention would be rivetted on his darlings in chase, instead of diverted to the rasping of Thompson, or the bruising of Jobson. These hunts were doubtless very popular, for there is nothing so taking as a bustle and stir, in which all are at liberty to share. That is what makes a contested election so popular. Men come out, and fuss, and canvass, and strut, and swagger, who are heard of no more until another contest comes round. There was another characteristic attendant on many hunts in former days, which is almost wholly lost sight of nownamely, hunts that used to hunt hare till Christmas, and fox after. We never hear of such establishments now-at least not arowedly - though there are, doubtless, some that will hunt hare either before or after Christmas; but there are still those ubiquitous gentlemen, the "oldest inhabitant," whose retentive memories are charged with the miraculous doings of the past-how they dragged up to reynard by daybreak 
-how Jowler unkennelled him-how Towler hit him off at the road, and what a dance he led them over hill and dale, till all the foot people were shaken off, and half the horses sent home sad and tired. These half-and-half hunts had an advantage not apparent at first sight, which bears upon the heading of our paper. By running hare till Christmas sportsmen got their soft horses into condition for the lengthened and more fatiguing fox chases that took place after.

The condition of hunters was certainly not generally understood, or perhaps attended to, until about twenty years ago, when "Nimrod" essayed his letters on the subject. We do not mean to say that large first-rate establishments were ignorant of the subject; but certainly tired, stopping, and dying horses were much more common before he wrote than they have been since. Indeed, we seldom hear of a horse being killed by sheer riding, unless in the hands of some raw, enterprising beginner, who has omitted no opportunity of taking a gallop whenever he could get one, needful or otherwise-a gallop being a gallop with some, and quite as enjoyable without hounds as with.

Mr. Beckford, in his "Thoughts upon Hunting," glanced at what "Nimrod" afterwards wrote into a system, namely, losing all the condition gained by the work and the feeding of winter, by turning the horses out to grass in the spring. Mr. Beckford, we imagine, had been of the grazing order; indeed, for any but a few countries, there is no doubt but the old-fashioned system, with proper management, will always produce condition enough for all legitimate riding to hounds. The heat and flies of summer used to be the great argument against turning out; but, as summers go, it is very seldom we have much to complain of in that way. Doubtless the house system is the surest and safest way to hard condition, but it is much more expensive than the other, though of course its 
advocates always swear it is not. A man's hobby never costs anything.

"Nimrod's" letters on condition did a great deal of good, though perhaps he was rather in the extreme, at all events induced men to run into the extreme, who lost sight of the fact that "Nimrod" took Leicestershire for his standard, and that what might be necessary there might be superfluous elsewhere. Besides, it is evident that with the variety of constitutions, tendency to lameness, and infirmity of horses, no general rule can be laid down for their management. Treatment adapted to each case seems to us a sounder and more sensible system. We advocate clipping, a practice "Nimrod" never could bring himself to hear of, though there is no doubt that all who have tried it will admit its wonderful efficacy. "Nimrod's" objection seemed to be its cheapness, and its tendency to make Grooms idle; but the former is an objection that poor men will readily pocket, and the latter is easily remedied by giving each man three horses instead of two to take care of. As times go, anything that tends to diminish the expense of hunting establishments ought to be adopted, and certainly clipping is a thing that not only saves labour to the servant, but also needless annoyance and irritation to the horse. A Groom never knows when he is done with a woolly-coated horse, for after he has strapped him, and rubbed him, and got him, as he thinks, after much toil and labour to himself, and plunging and kicking and wincing on the part of the horse, all right and comfortable, very likely, on going into the stable an hour or so after, he finds the horse all broke out again into a cold clammy sweat, and all the rubbing and whisping to do over again. Take the animal's pea-jacket of a coat off, either by clipping, shaving, or singeing, and he not only looks five-and-twenty per cent. better, but he thrives to the extent of five-and-twenty per cent. more, and does a 
third more work into the bargain, with half or less than half the trouble to the Groom.

Clipping used to be quite a trade, nay, it almost threatened to become a "profession" at one time, so high did the artists run up their prices; but the humbug of the thing is exploded, and prices are down. With very few exceptions, all the fellows who go about the country clipping are mere grooms and helpers out of place, who can't clip a bit better than a man's own servant. Then when they get into a house where the master is weak enough to let them have wear and tear for their teeth, unless they have another victim in view, they are in no hurry to take their departure, and a horse will serve them the best part of a week. Travelling rat-catchers and itinerant grooms are things that should be carefully avoided. It is a far better plan for a master to keep a set of clipping scissors of his own, and let a Groom try his "prentice" hand on a hack or some horse that is not much wanted or seen, than to take in one of these chance-coming clippers. A grey horse, for instance, shows bad clipping less than any, and a man must be a very numb hand if he does not get into the way of the thing after going over a whole horse. Besides, a man's own Groom clips at his leisure, at those midday hours that are consumed in the saddle room, in polishing that eternal curb chain, Grooms always have in hand, or ready to let fall, the moment they see "master coming." A real clipper will clip a horse in a day, and most likely charge a guinea for it, which, it must be admitted, is pretty good pay. We have heard of two guineas being paid in former times.

Shaving is a still easier process than clipping, and we wonder it is not more generally adopted. Any man who can shave himself can shave a horse, and shaving is attended with far less fatigue to the hand than clipping. The veriest beginner can shave a horse a day-the Groom, village barber, sexton, any- 
body. It requires nothing but half-a-dozen razors, hot water, and common soap, well lathered in to the part you are at work upon. There should be a man or boy to hold the horse, one to shave, and a third to keep setting the razors, as it makes awkward work when the shaver has to stop every now and then, dry his hands, and commence whetting. It is a more efficacious process than clipping, and gets rid of much of the singeing and smell-making that concludes that operation. The only difference in point of convenience is, that you cannot well ride a shaved horse without clothing for a week or so after the operation, whereas a clipped one will come out the day afterindeed we once saw a horse out with hounds in Kent, whose fore-quarters were rough and shagey; and the hind ones smooth and smart, looking very like a French poodle, a likeness that was increased by the monkerfied appearance of the man upon it. As to the risk attending either clipping or sharing, we confess we never saw or heard of any ill effects arising from either, though, as we said before, we have seen and felt very great advantages. We may, therefore, be called "clippers."

Now to the general subject of Grooms and condition.

A real Leicestershire Hunting Groom treads closely on the heels of the Training Groom, with respect to condition: he is, in fact, a Training Groom without the "humbug," at least he ought to be without it. Some men keep Grooms to be their masters, and to these the real Training Groom perhaps would be the thing. They then would not get a glimpse of their horses, save by sufferance. We have no notion of paying a man to be our master. A gentleman ought to be just as good a judge of the requirements of a hunter as a Groom, indeed he ought to be a better, because he is the man who has ridden the animal, and he also is the man who knows when he wants to ride 
him again; it therefore seems the height of softness and absurdity for a master to put up with the not uncommon answer to a message that he wants to see his horses, that the stable "is shut up." This is carrying the mystery and humbug of the racing stable into the hunting one. It may be right, and necessary in the racing stable; we don't pretend to give an opinion on that point; but in nine cases out of ten it is sheer humbug as applied to hunters. Many a man, we believe, has been choked off hunting by the over condition of his horses. Some Grooms have but one system - the very tip-top condition, good nerves, bad nerves, or no nerves at all. First-rate, race-horse condition may be all very well for Sir Rasper Smashgate, who rides fourteen stone, with the nerves of a Roman gladiator, but for little Paul Poplin, it is nothing short of cruelty to put him on an over fresh horse-cruelty the most refined, for you make the poor victim pay for his suffering. What can be more humiliating to a man of "taste, enterprise, and spirit," as the old "Sporting Magazine" used to put on its title page, than being hurried here, there, and everywhere, knocked against gate-posts, dashed among trees, bumped against acquaintance, by an impetuous, overbearing, resolute horse, that the Groom has been coddling and spicing for the show off on this particular day. Horrid reflection, when there are five or six more waiting their turns to do the same thing !

In hiring a Groom, as in buying a horse, it is very material to see whether they are adapted to the work we intend to put them to. Hunters are not like carriage or park horses, that can be kept for show with impunity, and it is no use a man hiring a Stud Groom and buying six or eight horses merely because he happens to have plenty of money, when a less aspiring servant, with fewer nags, would make him much more comfortable. He had better lay his money out in plate, or in some less troublesome article than hunters. 
He must not mind being called shabby. Surely a man is not to make himself miserable for the sake of being called liberal. Of all charges that of shabbiness, "closeness," is the commonest and easiest made. If a man's stomach is not equal to the "drenching" dinner-giving entails, and he is sparing of his feeds, he is called shabby. If he gives dinners and does not push his wine, he is said to be trying to save it. If Dick Sharpwit tries to do him with a horse, and fails, Dick dubs him a "screw;" and so they ring the changes on the charge through all the transactions of life. Nothing, however, insures a man the charge of shabbiness equal to foiling another in a do. It is propagated with double rancour, for the delinquent to screen himself and get his revenge. The man must lead a wretched life who troubles himself with thinking what "the world says of him."

It may generally be remarked, in looking over a hunting field, that the Grooms who are the neatest and best turned out themselves, have their horses best turned out too. This turn-out of self is difficult to define, varying, when out of livery, according to the taste of the wearer, and when in livery, restricted a good deal to the cut and putting on of the clothes. A woolly-hatted Groom has always a shaggy-headed horse. That is a rule admitting of no exception. Dingy-clothed Grooms, with inky-looking tops, have always dull-coated, ill-conditioned horses. Fellows with Britannia-metal-looking spurs, gloveless fists, sloggering boots with the straps hanging out, unbrushed coats, burst seams, stained waistcoats, flying-ended neckcloths, generally have their chokebands as tight as they can draw them, and the head-stalls of the bridles flapping about, with buckles and bits as dull as pewter. Some fellows can "dress the Groom" and can do nothing else. Others, again, are fond of horses, just as a child is fond of a kitten; but, as to any real hard work about them, that they have 
no taste for. These creatures are only fit for pony phaetons, or Mr. Brown's one-horse chay. Of all abominations, however, that of slang servants is the greatest-fellows who lard their answers with cant terms, get their waistcoats as near their knees, and their breeches as near their ancles as they can.

An ill-mannered servant is a thing no gentleman should have. Manner is a thing that speaks for itself, therefore a master has no excuse in saying he did not see the want of it when he hired the servant. There is nothing bespeaks the low-lived ill-conditioned fellow so much as calling gentlemen by their proper names, as Thompson, Simpson, and so on. We know servants do it among themselves; indeed, it is in consequence of their doing it among themselves that causes some of them to slip it out before their masters ; but candidates for place may rely upon it it is very bad policy letting an expectant master hear it. No judge would ask any questions after such a display of familiarity. Touching the hat is a thing there is less of, the lower we get in the scale of servitude, till we reach John Hawbuck fresh from the plough, who gives a familiar grin, and says "it's a foine day." We remember the observation of a nobleman's Stud-Groom one day, on seeing a newly-caught yokel of theirs answer a gentleman without the touch of the hat, which was, that "there would have to be a deal more politeness before he did for them."

Touching the hat is an art, and can be made to convey almost as much meaning as words. My lord's servant will take his off, even to a commoner, if the commoner is a friend of his lordship. Mr. Plantagenet's will do the same, or raise his hand slowly and respectfully till he gets fairly hold of the brim. Captain Bolisher's, of the heavies, will give a sort of back hand salute. Mr. Rattlebar's, whose master drives the coach, gives a comical sort of twirl of his arm, as though he wanted to look under his 
elbow ; while Tom Tinker, Mr. Loosefish's young man, gives a quick snatch, when he is just upon you, as though he hardly thought you worth a salute at all. We have observed that servants whose places are tottering become singularly assiduous in the matter of the "felt," and we have even known Grooms out of place subsisting entirely upon the precarious income derived from touching theirs.

Grooms are about the only servants upon whom masters can form anything like an accurate opinion, and it would be well for them to remember that fact. The communication between masters and all other servants is so slight, and occurs at such stated and expected periods, that it would be odd if they could not raise sufficient manners to pass muster; but Grooms-stable-servants in general-hare the "eyes of England" upon them, as "hard-up" orators say. Not only is the private eye of England (the masters) upon them, but the real public eye of the world at large.

Every Groom, who enters the hunting field--every Groom, as he passes along the street-rides as it were upon his character. His horse and himself show what he is.

There are two things we make it a rule never to keep, a drunken servant and an oil lamp : and we go upon much the same principle in both cases, namely, that the servant is sure to be drunk, and the oil lamp to go out, when we want them. Drunkenness is an inexcusable vice in any servant-least of all in a servant entrusted with horses; yet how many fat, comfortable-looking old ladies we see getting into their carriages in the country, to be whisked home by fellows who have been boozing in the tap-room all day, and whose fine cutting and tearing earns them the reputation of "excellent coachmen." Women think of nothing but going fast. If they are fast driven they think they are well driven. That, however, appertains 
more to the branch "Jehu" than the peculiar class of servants under consideration.

"Honesty, sobriety, and civility" are the cardinal qualities inquired after in character; but there is another very important one, especially in a Hunting Groom, "punctuality," that should never be lost sight of. Want of punctuality counterbalances almost every good quality. Half an hour-nay, five minutes-is sometimes everything in a hunting morning. Fancy a man coming twenty miles to meet hounds, and his horse arriving five minutes after the last craner has taken the distant fence, the panting hack sobbing as the master sits straining his eye-balls-now after the hounds, now in rain research about the country. If any one were to put the following query to us :-

"Would a master, whose Groom was late with his horse, and so lost him 'the run of the season,' be justified in quilting him?"

IVe should answer-

"Most decidedly yes--lay into the warmint!"

Perhaps we might add-

"Beware that he's not too big."

Want of punctuality attaches to both ends of the morning start. There is the want of punctuality in getting away from home, which entails hurrying on the road, and is more common than the want of punctuality in arriving at the meet. A fellow who can't get out of his bed of a morning is only fit to sit in feathered breeches and hatch eggs. Somebody said of a once prime minister, that he always seemed as if he had lost half an hour in the morning, and was running after it all the rest of the day; and assuredly there is nothing so annoying as a servant, who, for the want of the early half hour, hurries and jumbles the work of two hours into one.

To a punctual person there is something strangely self-speaking, erident, and significant in the morements and appearances of an unpunctual, dilatory, 
behindhand servant. We will suppose the master shaving, at which critical period, instead of seeing the stable door open, and the horse going away, Tom is running about in his fustians; then, when at length he does appear booted, the saddle and bridle make their appearance, and have to be put on, till at last the master, in ungorernable fury, hurries on his things, vowing he'll go out and lick him, when he sees Tom rushing out of the stable, scrambling on to the horse, and cutting away at the rate of ten miles an hour. An unpunctual man is always an irregular man, he

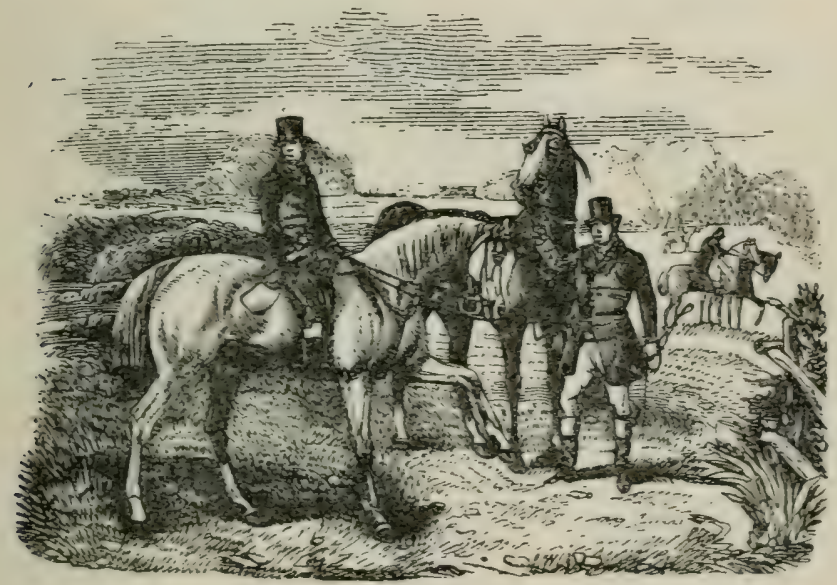

never knows where he has anything. We like to see a quiet, orderly, methodical Groom, who knows where to lay hands on what he wants, and who does his work as though it were his daily custom, and not something out of his usual way.

There is nothing so bad as a hurrying, scuttling, muddle-headed servant in a stable-a fellow who never knows where he has anything, and who is always applying the wrong article for want of knowing where the right one is; "making shift," as they call it. Again, we have seen fellows who thought to 
ingratiate themselves with their masters, by showing unusual bustle and activity when they were in the stable-snatching at this, pulling at that, and dashing here, there, and everywhere. That sort of work won't do with horses. A man must have a head as well as hands before he can be called "a Groom." 


\section{CHAPTER XI}

\section{THE GROOM-continued}

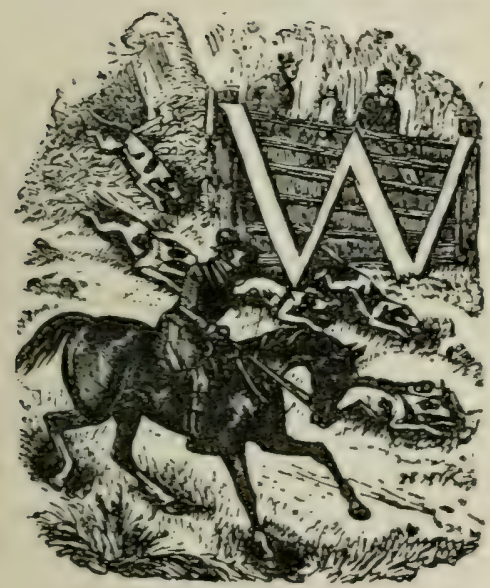

ILLING servants are a "real blessing" to masters, as the soothing syrup people advertize. Willingness covers a multitude of sins, and saves many a graceless dog his place. Willingness, however, is a thing confined almostentirely to small establishments. Let a servant be ever so well disposed that way, when he gets into a large establishment, he is obliged to conform to the rules and ordinances of the place, and do nothing that can by any possibility be considered the work of another, or that the odd boy about the place can be made to do. Idleness is looked upon as a sacred right, a right that each new comer is bound to preserve inviolate, and transmit to his successor perfect and unimpaired. The true dignity and duties of servitude are only properly appreciated and perfectly understood in large houses. Whoever got his hat brushed at a duke's?

"Willingness" of course includes pleasantness of manner; for it is hardly possible for a fellow who 
goes slouching and muttering away to obey an order to be called "willing." A man may never absolutely refuse to do a thing, nor ever neglect to do it, and yet be a most unpleasant and unwilling servant-one that we would rather do a thing ourselves than give an order to.

It is related that one of the Dukes of Bedford used to declare that he was never so happy as when he awoke in the morning on a journey and found himself in a chintz bed, instead of the stateliness of Woburn; and we, in our humble meditative rambles, often think, as the opening door of some great house discloses the bedizened and bepowdered retinue of servants, what misery, what hardship it would be to have them calling us "master." We, who direct the energies of willing and industrious hands, shudder at the thoughts of ruling a handful of idle, overfed lackeys. "What can they be all kept for," we sometimes think. Surely all the owners of these great houses cannot be like the unfortunate Miss Biffin, born without arms or legs, and incapable of doing anything for themselves. And then a thought strikes us that these are the necessary concomitants of wealth and station, and hurrying on we thank our stars that we were not born with a "sideboard of plate in our mouths," as Dickens would say.

"The servants are the gentlemen of England," says Sam Slick. "Next to bein the duke," writes he, "I'd sooner be groom to a gentleman that sports a four-in-hand than anything I know of to England: four spankin, sneezing, hosses that knows how to pick up miles and throw em behind em in styleg'long you skunks, and turn out your toes prettywhist-that's the ticket-streak it off like iled lightning, my fox tails; skrew it up tight, lock down the safety valve, and clap all steam on, my busters; don't touch the ground, skim it like hawks, and leave no trail; go ahead handsum, my old clays-yes! the 
servants are the gentlemen of England; they live like fighten cocks, and yet you hear them infarnal rascals, the radicals, callin these indulgent masters tyrants, endeavourin to make these happy critturs hate the hand that feeds them, telling these pamper'd gentlemen they are robbed of their rights, and how happy they'd all be if they lost their places, and only had vote by ballot and universal suffrage."

Sam is a true observer-many an over-fed fellow is talked into imaginary grievances that would never occur to him of his own accord, or if he was out of place. "Idleness," as the copy heads well say, "is the parent of all mischief," and it is much to be regretted that the system of great houses encourages idleness as it does in servants. Not only is it prejudicial to the servants themselves, but most injurious to those who may happen to be thrown in their way. People indeed of all sorts are so apt to think of what others have that they are without, rather than what they have that others are without. In place, a servant perhaps sees that servants in other places do not do what he is required to perform, and instead of recollecting how many hundreds there are out of place who would jump at his situation with all its imperfections, he tries by every device and shifty excuse to rid himself of what he is pleased to denominate "not his work." The moment a servant begins to talk in this strain, it is time to get rid of him. They never do any good after. Many, otherwise well-meaning lads, we believe, are laughed and talked into this kind of thing; others again adopt it naturally, from a sluggish, inert disposition. To the former we would say, "Reflect on what you may have to do if you fall out of place."

Until all masters' fortunes and ideas are alike, it is impossible to suppose that servants' places can be alike, or even that the place of one master can regulate or guide the place of another. "Every 
herring must hang by its own head," as the saying is, and servants must take each place upon its individual merits, without reference or regard to what is done or allowed at another. No master ought to allow a servant to quote the doings of another place to him. These observations are peculiarly applicable at the present time, for the increased and increasing facilities of communication, as well by post as by railway, have brought about such a system of note comparing and laying heads together, that half the servants are agog to know what the other half have. Then if Tom Brown finds out that Harry Jones has a couple of pounds a-year more than himself, he feels it a point of honour to ask to have his wages raised, forgetful very likely of the fact that he is in possession of a couple a pounds a-year more than Giles Scroggins at some other place. A servant's sliding scale only knows the ascendant. The breed of old attached family servants, so beautifully described by Washington Irving, will be almost extinct with their generation. Few new ones are rising up to supply their places. It may save annuities to expectant heirs, but we much question whether the new system is better for the general interest of families.

There are no people under the sun so well done by as gentlemen's servants. They live on the fat of the land, have no cares, no anxieties, and are paid out of all proportion to their labouring brethren. An inflated beef and beer bursting bragger will assert that he can do what a labouring man cannot; but a handy labouring man will do his own work and the braggart's at his leisure hours. What are the generality of servants, in fact, but part and parcel of the labouring population? They are not a bit better educated; if they were, they would aspire to clerkships or shopmen's places. All the difference is that one lights on his legs in gentleman's service, the other sticks to the spade, the axe, or the trowel, and, 
we believe, is often the richer and the happier man of the two. Gentlemen's servants are often sadly improvident. They have great temptations, it is true; but few, we fear, try to resist them. The easiness of comfort is soon acquired, and the chance of adverse circumstances is unpleasant to contemplate.

In hiring a Groom, or indeed a servant of any sort, it is always advisable to get them from places rather under than above those they are coming to. A retrograding servant is generally a dissatisfied servant, and as they always ride in the highest hole in the stirrup of their knowledge, they are very apt to think it necessary to instruct the new master in the style and doings of their best place; instead of serving, they assume the direction. In the country, the scale of servitude is as nicely understood, and the position of families as accurately settled by servants, as the hereditary nobility is by Mr. Burke or the Heralds' College. Grooms from great places are often full of whims and conceit, and think nothing can be right but what was done at Sir John's or my lord's. Masters are great fools to submit to anything of the sort. No two books, let alone two masters, agree upon even the most ordinary point of stable management. Take feeding, for instance-one man will tell you that hay should be given in about the quantity of I 2 lb. a-day; but if you go into a barrack yard, and ask a soldier what his horse gets, he will tell you Slb. is the allowance. The more ignorant a Groom is, the more mysterious, conceited, and pedantic he is, the more he talks about his infallible receipts and nostrums, known to none but himself, or confided by some equally great authority. These sort of pretenders are only for young men, the old stager knows the simplicity of condition too well to be talked to in that strain. One of the absurdities of the times is making everything as complicated and mysterious as possible, using hard words where hard words can be 
brought in, and dividing and subdividing trades, professions, and occupations. The first thing a lad does now-a-days is to set up a watch, after which, if his mind incline towards horses, he buys what he calls a "printed book" about them, and thinks himself equal to Field, Mavor, or Goodwin. The real requirements of horses are very few and very simple: good food, good grooming, good stables, and work proportionate to the food and constitution. Apportioning the food to the work is a thing that never enters the heads of nine-tenths of the horse hissers, calling themselves Grooms; their great anxiety always being to get as much food down each horse's throat as they possibly can. They are quite unhappy if they can't cram four feeds down a day. We would rather see them keen about giving them plenty of exercise than plenty of corn. It is in the exercising department that half the stable servants fail. Young lads are especially slack, and some have the still worse trick of trying to put two hours' exercise into one by hurrying, trotting, and cantering. We have seen urchins rushing with their horses out of the stables, jumping up, snatching their bridles, and cutting away as if they were riding for the midwife, instead of going out in that leisurely, orderly way, that belongs peculiarly to the word exercise-exercise in contradistinction to errands or work. Indeed there is not one boy in fifty fit to be trusted with horses, we mean fit to be left in the entire charge of them. They should always have a man over them. Let the reader recall the equestrian performances of his own boyish days, the hurried and protracted ride, the secret gallop, the stealthy leap, the quiet race, and say whether he would have been a fit person to trust with a valuable horse at that time of life. Talk of years of discretion at one-and-twcnty! Let a man of forty ask himself if he was discreet at one-andtwenty. 
Exercising before breakfast is a great promoter of short commons in the walking department, and a great inducement for an early return. We do not know why Grooms should like having their horses out before the world is properly aired, but certainly the managers of large studs generally adhere to that system. In the old days of mails and coaches, we have often passed whole strings of sheeted and hooded horses in the environs of different hunting quarters, as we have whisked by in the opening mist of early dawn. Six o'clock is the usually prescribed stableman's hour for being with his horses, which is two hours before daylight in winter. Doubtless the earlier a man is at his stable the better, to see that all is right and quiet; but we think it would be better both for horse and man, if, after setting things fair and straight, the latter returned to his breakfast, and took his horses out after sun-rise.

Sheeting and hooding horses at exercise to the extent we generally see them, and then sending them out next day with only a saddle on, seems almost an experiment on health. Again, how seldom we see them clothed according to the state of the weather and the season of the year. What is once put on is generally kept on. It is a good rule in hunting stables, where horses have to lie out often, to clothe lightly at home. An extra rug or sheet will then tell should the Groom get into a bad, cold, or unaired stable.

Galloping horses to get them into condition is a dangerous process, and one in which, we believe, more are lamed and broken down than by regular work in the hunting field. Taking a horse into a field by himself, oppressed with fat and clothing, and kicking and bucketing him about till the sweat runs down in streams, and he is fit to drop, does seem an abuse of the noble animal that nothing can justify. The horse does not know what it means, what you 
are about, or what he is expected to do. Instead of the quick, self-containing, energetic stride that he takes in the excitement of hunting, he blobs and flounders about, drops his legs and rolls like a bullock till the senseless brute on his back either tires himself or feels the horse failing under him. In sweating, as in ordinary exercising, the compression system-the putting an hour's work into half-an-hour-is often the fatal fault. We all know that we can sweat a horse by common road riding; what then is to prevent the necessary reduction of flesh being made quietly under clothing? Nothing, but that it requires more time. Galloping does it quicker, and lads like galloping best. Then the way they saw and haul, and hang on by the mouth is truly awful.

We remember in the days of our adolescence, folding a shilling in a nice clean crisp "Henry Hase," with the $\mathcal{E}_{\mathrm{I}}$ mark figuring like a raspberry tart at the corner, for the purpose of giving it to the first Groom we met riding on the snaffle, and feeling his horse's mouth as he went. Well, we carried that "Henry Hase" for weeks and months until the shilling wore itself through, and we daresay we might have carried it till now, without meeting with such a rarity in London, as a Groom riding on the snaffle. They all hang on by the curb.

If a Groom can give a ball and bleed a horse, we would compound for all the other knowledge in favour of that first of all essentials, good "elbow grease" and exercise. "Giving a ball," indeed, is about the extent of some of their ability in the physicing line, the proper preparation of a horse for it being much beyond the march of their intellect. If a horse is difficult to move, instead of lengthening the period of his preparation, they increase the quantity of aloes, until we have seen a poor beggar with near a dozen drachms in his guts. In these cases Grooms always swear the aloes are bad, or the bran is bad, or the water is bad, 
or something is bad-anything but that their management is bad. Some fellows are fit for nothing but inventing excuses, and uncommonly quick and clever they are.

Veterinary surgeons are now so distributed about the country that in anything out of the ordinary way it is best to send for one of them. With horses, as with men, cold and repletion are the principal causes of illness, and when bleeding and physicing fail, let not a master persevere, but send for the "vet." Horses sometimes fall lame without any one, not even the "vet," being able to discover the seat of the lameness, and will as suddenly get well and disappoint all the prognostications of the learned. Physic is then the thing-it can do no harm, if it does no good -given in moderation, of course.

Shoeing is a thing that the green-horns of service are little acquainted with the importance of. They are always "just going" to get their horses shod, let the shoes be ever so thin, when they are asked about them. Foot lameness, that curse of good horseflesh, whose origin "no one knows nothing of," may be all traced to indolent, ignorant stablemen-Grooms we will not call them-and clumsy unskilful blacksmiths. Some men make a fuss about seeing their horses fed; we would rather see them shod. Shoeing is a thing upon which doctors differ, as well as upon other points. One man will tell you that the shoe should be made to fit the foot, and not the foot burnt with the hot iron to make it fit the shoe, while others will say that if the shoe be not burnt and fitted well, the crust breaks and shivers up. Both these statements may be found in "printed books." Perhaps it may be enough for us to observe that a horse should be shod every three weeks or a month, and that it is better to get them shod every three weeks, than removed at that period, and shod at the end of the month. The less wrenching and country-smith 
working there is about a horse's foot the better, as we well know.

On this point, however, we shall enlarge when we come to treat of our friend Elijah Bullwaist, the blacksmith, whose rubicund visage now greets us as he enters the hunting field on his shaggy white pony.

Instead of seeing a saddle-room shelf studded with bottles and boxes, we would rather see a good assortment of combs, brushes, scissors, towels, buckets, sponges, leathers, knee-pails, and such like things. Warm water is a grand specific. It is like the tongue of the dog to a wound. A little sharp water is useful in cases of cuts and over-reaches. The following is a good recipe taken from Mr. Smith's "Diary of a Huntsman," and he recommends a Whipper-in carrying a small phial of it, with a feather in the cork, ready for immediate use :-

$\delta$ drops of oil of thyme

Io drops of oil of vitriol

I ounce of spirits of wine

As an alterative medicine the following recipe was given us by an old sportsman endorsed "an excellent medicine for horses:"-

$\begin{array}{lll}4 & \text { ounces of nitre } \\ 4 & \text { do } & \text { antimony } \\ 4 & \text { do } & \text { cream of tartar } \\ 4 & \text { do } & \text { sulphur }\end{array}$

Mix, and give it once or twice a week in their corn, about a tablespoonful at a time.

Instead of inquiring into an ordinary working Groom's scientific acquirements, his knowledge of "Taplin," the "Gentleman's Recreations," and so on, we would infinitely prefer putting him into a loose box beside a dirty hunter, and seeing him set to work. There is something about a workman, be he a joiner, painter, glazier, mason, or what not, that proclaims 
itself even to the uninitiated in the craft, and in no case more strongly than in a strapper. Look at the poor, miserable, feeble creatures that stare at your horse as you dismount at a third-rate London livery stable, or in an ill-frequented country inn yard; see how they potter and dribble and fistle about the animal, fearing as it were to tackle with him, and when they do, most likely commencing with that abomination of all abominations, whipping off the saddle, and contrast their dawdling, inert movements with the prompt, vigorous decision of the well accustomed stable-man, who is stripped to the shirt, has the bridle and stirrups in hand, girths loose, and hunting martingale off before the other poor ninny has got his shirt sleeves turned up.

When at length Dribbles does begin to hiss, the chances are he does nothing but teaze and tickle the animal with his ill-arranged whisp, or having scraped a certain quantity of mud off its belly he will proceed forthwith to plaister it about the ears by way of making it comfortable about the head. The real workman having disencumbered the horse of his bridle will shake his litter up, sponge his eyes, nose, and mouth, and give him his gruel. We like to see the hunter getting his gruel, it must be as refreshing to him as a basin of soup to a tired man. Then he will give him a bit of hay, which will occupy the horse and keep him from snatching and biting at the man or the manger. Sponging under the tail and all about is a grand thing, and we should like to see more of it. Pulling the ears, too, is a thing all horses like, and doubtless tends much to make them comfortable about the head. Real good powerful strapping is quite as essential towards condition as feeding and exercise. Some fellows only strip horses and starve them.

Ascending a little in the scale of stable servitude, we will take a glance at the Second Horseman. The 
Second Horseman should know a little about hunting, and a good deal of the country in which his performances are required. This knowledge of hunting should be sufficient to keep him from doing mischief, at all events, while his knowledge of the country, and of the usual runs of foxes, should enable him to have his horse up, when wanted, fresh and fit to go on.

Looking at the second-horse system in its ordinary everyday aspect, we cannot, however, help saying, that there is a good deal of flash and humbug, in the majority of instances, where we see them out. Except for very heavy men, or very hard riders on rery good days, one horse ought to do all that reasonable riders need require. Gentlemen's horses are not like servants' horses, continually on the go. While the men are trotting and crashing over big places in a cast, gentlemen have nothing to do but turn their horses' heads to the wind, and give them their puff. Servants, in far the greater number of countries, have but one horse a-piece out, and theirs come more regularly and more continuously throughout the season, than the horses of any of the field. The servants, too, must be with their hounds, must go on to the end of the day, whereas gentlemen may shut up and go home at any moment they like.

Roads are now so numerous and accommodating, that a servant with an eye and moderate brains, ought to be able to pilot a second horse, without putting him to anything like work. Some fellows, however, never learn a country. They will ride over the same country for years, nay, will do the same circle twice in a day, without discovering that they are not going straight. They are like the lady who got into the inner circle of the Regent's Park, and walked for many hours, thinking she was never going to get round.

Many of the second horses that we see in the hunting field, however, are there from the repletion 
of the stables, and by way of exercise, rather than in expectation of being really wanted. Doubtless it is convenient to have two out; one may fall lame, lose a shoe, and the man who is provided seldom wants. Here, then, let us recommend Grooms to ride like Grooms, and not like gentlemen, in the hunting field. They have no business in the front rank; neither is it etiquette to pass in muddy lanes and roads. This latter hint may be useful to others than servants.

We do not exactly know whence the "Pad Groom" derives his title, nor indeed what, in a "Castle of

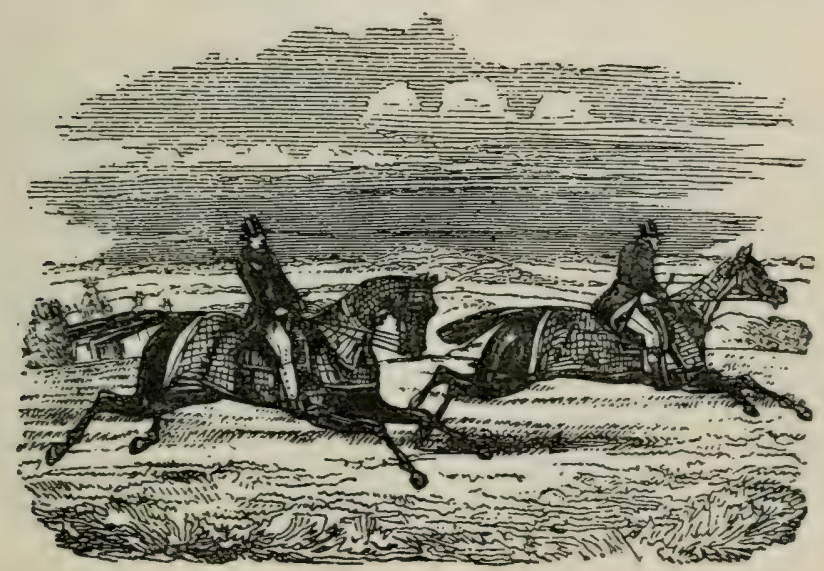

Indolence," would be considered the legitimate duties of his office. In the humbleness of our ignorance we have confounded them with the Second Horsemen, though we believe there is a distinction, without, perhaps, much difference. The "Pad Groom," we rather think, forms the sort of appendage to his master that the can sometimes does to the dog's tail - while the Second Horseman may flourish about the country, so long as he keeps on the line of the hounds. The "Pad Groom" should act as pioneer, and be always ready to ram through a bullfinch, or blind fence, it being derogatory to a gentlemanto 
risk his neck, when he can afford to keep a man for the purpose. Paddy should be an adept at opening gates, throwing down walls, breaking rails, and great generally in the art of destruction.

If the Master should be unlucky enough to kill his horse, he would then take the "Pad Groom's;" in which case, as the latter would most likely have to "pad the hoof home," it is not impossible that some such catastrophe may have led to the creation of the title; or, it may be that the "pad," on the death of the fox, is consigned to the guardianship of this hero by ambitious claimants. 


\section{CHAPTER XII}

THE GROOM-continued

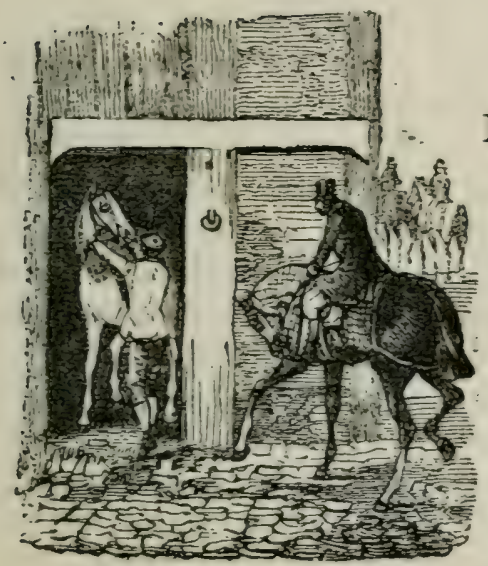

$\mathrm{HE}$ sagacity both of hounds and horses in the matter of hunting is truly astonishing, and we hardly know to which to yield the preference. It is an undoubted fact that many of what are called trencher-fed hounds, learn to know the hunting days, and will sit at the doors listening for the summoning horn, or travel to the usual place of meeting by themselves. An old hunter knows just as well as his Groom the preparations that indicate the coming chase, and is as delighted as ever he can be. Shortening the supply of water is one of the usual concomitants, but if a horse was left to himself, he would never drink more than he ought. We mean if he was left to his own discretion entirely, with a constant supply of water within reach. Of course when he only gets it at stated intervals, and then oftentimes less than he would like, he acquires a greedy sort of swallow, that hurries it down as quickly as possible, as he does not 
know how soon the pail may be withdrawn from his head.

Some horses are much more fretful and much more easily excited than others, but as a general principle, fretfulness is more the characteristic of young horses than of old ones. Indeed, fretfulness is such a drawback to a hunter, that a horse that carries it beyond years of discretion, say seven, is generally recommended "to turn his attention to something else," as they say in the Guards when they want to get rid of a man. Young horses may readily be excused for a little nervous irritability with so exciting a cause as the chase, and it should be the duty of the Groom to remove all causes as much as possible, and keep things as near their usual course and appearance as they can. For instance, in taking a young horse to lie out over night, instead of leaving him in the stable when the others go to exercise, and then about the middle of the day stripping him and rolling up his things and fussing about the stable, putting all agog, he should just lead him out when the others go to exercise, sheeted and all, get his stable things quietly up, and ride leisurely and easily away, without all the fuss and elbow working that says to the horse as well as to the whole world- "here we are away for the Mountain daisy, to meet Squire Rattlecover's hounds to-morrow." Because horses can't talk and hold dialogues with their riders after the fashion of Balaam's ass, some fellows fancy they have no more instinct or memories than the saddles on which they ride. Starting for cover in the morning, again, should always be done as quietly and soberly as possible, where a horse is at all subject to nervous irritation. The sight of a scarlet coat in advance will set many a horse off, that would otherwise have been got coolly and comfortably to the meet. Some gentlemen have a nasty trick of going out to breakfast on hunting mornings and setting whole strings of horses on the 
fret by cantering past them in scarlet. A Groom should never calculate on doing more than five miles an hour in going to cover. Some horses will go six comfortably, but five is about the pace. The first thing he should do on arriving, of course, is to get his horse into a stable or outhouse, where with the aid of a little clean straw and a stable towel, he will remove the mud sparks from the horse's legs and renovate the polish of the bits, buckles, and stirrups. A damp morning soon clouds the steel. It is these trifles that mark the difference between the Groom with the head from the one without. Some men seem to think if they start fair and clean, or are neat and clean, once a-day, that is all that can be required of them, and that they may get themselves, their horses, and all about them, dirty, tarnished, and daubed, without any reflection on their care and neatness. "They have got dirtied since they came out," they say. A neat servant not only avoids all collision, but removes little casualties as they occur. There is a wide difference between a neat man and a smart man. The neat man is always neat whatever he has on, the smart man is often the creature of the moment that degenerates into the carelessness of the sloven after a flourish.

Lying out over night and mixing in the tap-room society of stable-yards, is a sad trial for servants, and the less a master throws them into that sort of temptation the better. It is not only the drinking, swearing, and gambling that not unfrequently goes on, but tricks are taught that often prove the ruin of lads; charging for things they never get, putting down more than they pay, and various other devices that all sooner or later end in ruin. Servants who wish to do justice to themselves and their masters, should never pay anything without getting a bill of particulars and a receipt. They then can send them in along with their books, and if wrong is done, the master 
sees where to apply, and the servant stands exonerated. Grooms, hunting ones in particular, may rely upon it that gentlemen know the price and value of most things just as well as they do, and it does not follow because a master is not always storming or kicking up a row that he does not observe what is wrong. A dishonest servant is sure to "catch it" sooner or later.

But if we deprecate the country inn yard, what shall we say to the abomination of some London livery stable ones. Why, in the words of the author of the "Young Groom's Guide and Valet's Directory," that a few weeks at such places has been the ruin of many a young man. There is nothing, writes he, "but drinking, tossing, colting, \&c. going on from morning to night; it begins, as Blacky says, by drinking for dry, and then comes drinking for drinky, and so on to the end of the chapter." Purl the first thing in the morning before their eyes are hardly open; porter at lunch, porter at dinner, and again a double dose at night. Then, there they are the next morning, some with a splitting head-ache; some so sick and squeamish that nothing but a hair of the same dog will cure them; and the cry is, " $\mathrm{d}-\mathrm{n}$ it, I cannot do my work without my half-pint of 'purl.' Well, away they go for this precious stuff, and, at the corner, probably meet with some more 'purl drinkers;' and then it is nothing but tossing up and tossing down, till they return back, half stupified and muddled before they begin their work, and are soon obliged to take another draught to quench the thirst and fever produced by the first."

That is a sad picture, but we do not believe an overdrawn one of some of these places, and masters should pause ere they consign a lad to such a scene of temptation.

One of the most important duties of a Hunting Groom is taking horses out over night, and making the best of bad stables. Fourteen miles is as far as 
a horse should go from home on the morning of hunting, and when distances are beyond that, with the probability of the draw being still further away, it is always desirable to let them lie out over night. No doubt a horse does better in his own stable, just as a man does better in his own bed; but fourteen miles is quite distance enough; and even though some horses may do more with impunity, still it takes a good deal away from the pleasure of the day for a man to think that he has not power enough under him to do what may be required. Imagination has a great deal to do in the enjoyment of the chase, as well as in other things. In going from home a servant should take everything he usually requires, and never calculate on finding anything at an inn. Having got everything there, his next care should be getting them back, for people are very apt to "borrow."

In naming fourteen miles as the outside distance, we are talking of meets which are towards home. Gentlemen, whose horses stand at head quarters, have a great advantage over out-lying sportsmen, inasmuch as they may readily calculate on their horses being able to do as much as the horses of the hunt; but supposing the fixture to be at the kennel, and a man travels fourteen miles to get to it, he need not be surprised at finding himself trotted half as far again on the other side before the day is done.

Lying out over night entails the necessity of being able to pack, a thing very few servants are up to. So long as they unpack, also, so that "master" does not see the state of confusion things are in, they are very easy how they are spoiled by being crammed and squeezed together. Soldiers' servants are always capital hands at packing. We often wish to get one of them to give a clumsy packer a lesson in the art. There is another thing soldiers' Grooms excel in, and that is in the saving of bedding. Instead of covering 
the wet litter with dry straw, as is too often done by lazy, hiding, hurrying fellows, they dry the wet straw in the air during the day, and it comes again nearly as good as ever at night.

But here comes the first flight of Grooms, with all the important top-boot bustle that proclaims the coming scarlets. See how they steal along at that "within-themselves sort of pace" peculiar to hunters. Let us step aside under the lea of this old barn, and scan them as they gain the field.

First, comes Timothy Jones, Paul Poplin's young man, all louped up in gold, with his mare in a white lather, and her mouth nearly deadened with the hauling of Tim's heavy hand. Tim and his master are recruits of the season, the master knowing as much of hunting as the man-boy does of horses. That hat, with the gold threads binding the oval sides to the gilt acorn on the crown is a contrivance of Paul and his sisters, the idea being taken from the Marquis of Dazzleton's footman. Tim's Groom's footman's coat, with the red and blue worsted shoulder knot, and patches of gold lace on the collar and cuffs, would disgrace anything but the rumble of a pony phaeton, and his red-seamed blue trousers and bluchers seem lost for want of the red string of the Italian greyhound. We don't know that we ever saw such an apology for a Groom in our lives, and how Tim will have the face to present that well-lathered mare to his master baffles our comprehension. Poor weak, washy thing! She has done her day's work already, and another such ride will finish Tim's military-looking over-alls. She has been the laughingstock of all the knowing ones in coming along.

This great woman-thighed, bull-headed, bloated, porpoise-looking fellow, with his beastly calves bagging over his lack-lustre, mis-shapen, painted top-boots, is Mr. Spavin, the horse-dealer's man, with a wellshaped screw for sale under him. At first glance you 
would think the fellow was a fool, till you arrived at his little rogueish black eyes, peering from among the lumps of fat composing his unhealthy ginnified cheeks. The fellow is the biggest scamp in the country. He lies like truth. He comes out as much to fish out the secrets of gentlemen's stables as in the hope of selling the horses he rides, though he is always ready to do his best in that way, particularly when he falls in with a flat, who he will persecute, and ride at, and talk at, with the audacious impudence peculiar to travelling prospectus men, railway surveyors, and small horse-dealers' men. He has been making a set at Paul Poplin's mare, making her as fidgetty and fretful as possible, in order the better to recommend the antediluvian beggar on which he is riding. The two Grooms in blue frocks and small-striped waistcoats next him are neat, and after them there comes a man made, dressed, and riding to our mind as a hunting Groom should be. $\mathrm{He}$ is short, light, and wiry. Forty summers may have passed over his head, leaving traces of the wear, but not the cares of life. On the contrary, his clear bright eye beams radiant on the cheerful scene, produced perhaps by the inward consciousness that his horse will not be eclipsed by any in the field. See how all that man's things are in keeping, from the hat on his head to the spur at his heel. The nap is as close and as flat as his horse's coat. There are no flowing locks protruding at the sides, the pride of housemaids and abhorrence of masters. There are no filthy, bristly, gingery whiskers fringing his cheeks, or extending round his chin. His horse and he are both well trimmed. His clean white neckcloth is well put on; no shirt collars appear above. His dark grey coat and waistcoat show the wear of work with the care of keeping, while his well-put-on dark drab mother-of-pearl buttoned breeches look as though they neither courted nor dreaded the assaults of the mud. Then the tops- 
there is more in top-boots than in any other article of dress-not only in the cut, material, and keeping, but in the art of putting them on. London Grooms -we mean men in the habit of coming to Londonare almost the only ones who really can put on topboots. This arises in a great measure from their having a proper respect for, and appreciation of, the article itself. There used to be a bootmaker in Paris, who, on a complaint being made by a customer, used immediately to ask if the wearer had been walking in his boots. If he replied in the affirmative, then St. Crispin would shrug up his shoulders, and, throwing out his hands, exclaim that he "expressly defended" his customers from walking in his boots, " that they were only for riding and carriage work."

London Grooms are the only ones who seem to have any idea that top-boots are only for riding in. A fellow in the country pulls them on at all times and occasions, from walking to church (or the publichouse) to driving the market cart. The consequence is, that after two or three good trudges and paddles in them, the boots lose all shape, make, and sit, and have that dejected melancholy air that only makes their fallen greatness more painful.

Boots and breeches, with the proper cleaning and putting of them on, give an air and character to the entire turn out. Who, on seeing a postilion in dingy leathers, and dull boots, ever thinks of looking at his horses? But to our Groom in the greys. His boots are well made, of good material, well cleaned, well kept, and well put on. The rose-tinted tops are longish, not affectedly so, but bearing a fair proportion to the boot itself. They fall in neat wrinkles down the leg, and the sole is clean and free from mud stains, instead of being marked half way up the instep, with the paddling about before starting. Contrast that man's appearance with the highshouldered, blear-eyed, Tom-and-Jerry-looking fellow 
in the black coat and waistcoat, all creases and whitening, from kicking about in the saddle room since the "last day," with a button off one, and a button out of the other leather breeches knee, the top-boots pulled up as high as ever he can get them, and the ends of a dirty twisted white neckcloth flying out at either side of a half-buttoned straggling waistcoat. The fellow looks as if he had slept in his clothes, or put them on in the dark, so hurried and ill arranged is he. He has heard that long-tops are the "go," so he has got them extra length, and daubed them so with putty powder, that if it was to come a shower of rain he would be the same colour from the knee to the heel. There is a generous supply of mud about his ankles, almost enough to constitute a forty shilling freeholder.

This great hulking, ill-countenanced fellow, on the badly-clipped rat tail, is what may be called a register-office servant-a fellow that is generally on the books, and gets taken up at short notice, in extremities. $\mathrm{He}$ is a sour-tempered, ill-conditioned fellow, who can only conduct himself decently for one month after being ground down by poverty and adversity for six. He is now a helper, and takes his master's horse to cover, though weighing three stone more than his master. When he applies for another situation he will dub himself "Pad Groom," or "Second Horseman," despite that he stands six feet high, with the brawny limbs of a bargeman. The register-office will endorse him as such, and there is no saying but by mere dint of impudence and want of contradiction, some flat may be taken in to hiring him-Second Horseman !-second ploughman, more like. What a ragged-looking rascal it is to send to cover. How anybody dare trust such a fellow with a twenty pound horse we can't conceive. If the horse patrol were to catch him near London, they would be sure to take him up for stealing it. There 
is something terribly self-convicting about a jobservant. Seedy, but painfully well-brushed hats, nasty frowsey tartan neckcloths, long ditto waistcoats, white-seamed, button-covered, greasy-collared dark coats, stained drabs with tarnished knee buttons, patched boots with sloggering caps, the whole set off with a pair of baggy Berlin gloves.

This old boy, blue and all blue, with the tarnished band on the greasy hat, is Cottonwool's coachman. What he has come out for nobody knows, unless Henrietta has sent him to look after Smashgate. Ah, see how old Blue Bluey greets the baronet's groom! There's a wring of the hand that looks like business. Trust a servant for smelling a rat! They are at once the best-informed and worst-informed people under the sun. They know everything and nothing-everything in the hall, nothing in the parlour. Who would have thought to see such a swell-consequential-looking man-gentleman, we might say-with white cords and basket buttons on his brown cut-away, doing the familiar with such a tawdry, dirty-clothes-bag-looking old file as that coachman-a man whose boots have evidently belonged to his predecessor, and whose plush breeches would hold two pair of such legs as his? Nevertheless there they greet. "Well, Matthew." "Well, Mr. Thomas." Not that Mr. Thomas thinks Henrietta by any means a match for his master; but Mr. Thomas having cast a favourable eye on the joint-stock lady's maid at Fleecy Hall, who, according to the usual etiquette of servitude, will accompany the first married "Miss," Mr. Thomas thinks it well to favour the suit. What with this double pull upon him, it will be odd if the baronet is not caught.

But enough for this paper is the scribblement thereof. If this lecture on Grooms should cause one untidy dog to survey himself in the limpid stream and amend his ways, one silly lad to give over considering whether this or that is "his work," one 
thoughtless master to pause ere he throws a servant into needless temptation, or induce one infatuated youth to dress his servant like a Groom instead of a strolling player, all we have got to add is, that we shall be abundantly satisfied if the benefitted party will send us a barrel of oysters.

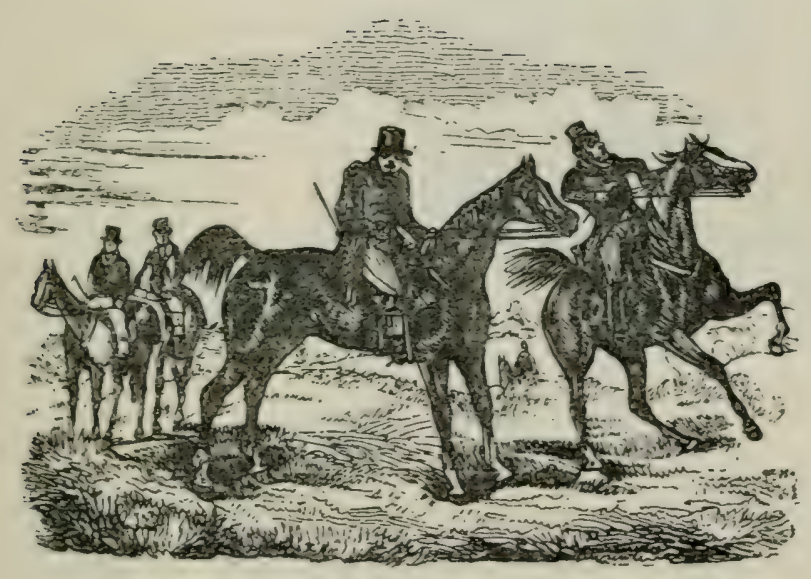




\section{CHAPTER XIII}

\section{PETER PIGSKIN}

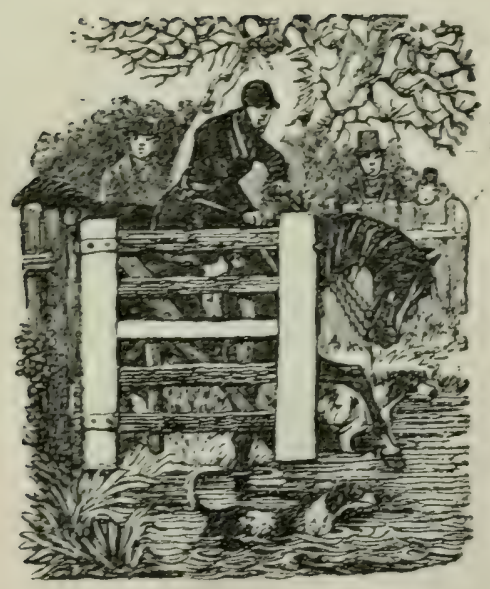

ERE comes old Peter Pigskin! Peter, of whose existence we have given so many indications, that we dare say our readers are puzzled to know who he is; Peter, the family stopgap and "back hander" at Cottonwool's ; Peter, the man who it does one's heart good to see

feed; Peter, the man who sings

"We won't go home till morning,"

and who most probably practises what he sings. Now, what do our readers think Peter is? A Sportsman, it is quite clear, or he would not be in our "Analysis ;" and, sportsmanlike, his early appearance procures him the honour of our first salute.

When we commenced these sketchy papers we little anticipated that the opening numbers would stretch themselves into so many parts; yet so they have, and this only fairly launches us among the field. As yet we have only dealt with the "master" and the "men," as it were, leaving the wide range 


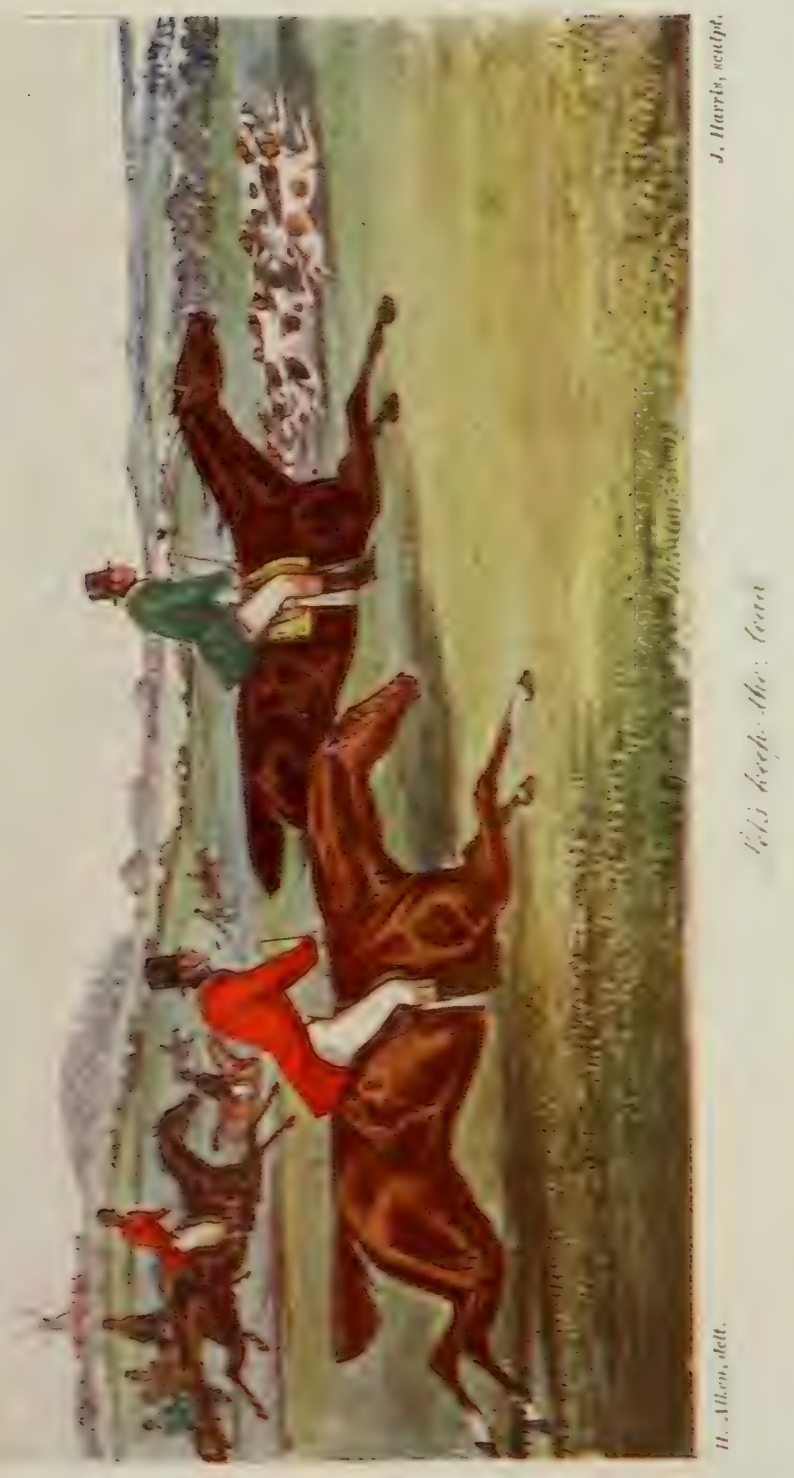



of character and station forming the ingredients of a hunting field for discussion and description. The uninitiated may suppose that a "field" is merely composed of one set of people, drawn from the same class of life; but the foxhunter knows how different is the fact, and how foxhunting reverberates, as it were, through the whole of our social system; how the joy that a good run inspires in the breast of the peer descends through all classes, even to the humble pedestrian who witnesses either the find or the finish. "Foxhunting," as was well said by Beckford, "is the peculiar sport of Britons," and we trust it will never be obliterated from the national character. It is a fine, generous, comprehensive sport, that every true follower delights to see his neighbour partake of. It unites all classes in brotherly union, like Shakespere's military offer of brotherhood, "be his profession ne'er so mean."

We need scarcely say that Peter Pigskin wears a dark coat, for whoever saw a meet of foxhounds where a dark coat did not arrive first? It is not a black coat, but a dark coat; a bottle green, with metal buttons, straight cut, single breasted, and short. Peter is a man that has been elevated by foxhunting; not ridiculously raised above his station, but a man whom foxhunting has brought into contact with parties he would not otherwise have become acquainted with. Peter now, and Peter fifty years ago, are very different people. The little, light, bow-legged, shrivelled, grey-headed old man whose clean but queer-cut clothes bespeak defiance to the elements, was then the smart, straight, dapper postilion to the Duke of Blazington, and rode the leaders of his grace's coach and six. In those days great men turned out like great men, and not like great midwives, or great jewellers, as too many do now. The Duke drove his six richly-caparisoned horses, whose flaunting manes were entwined with a luxuriance of ribbon, 
and whose long tails were protected from the mud by midway gatherings of the same material. Peter was then in the flush of youth. His plump, healthy cheeks glowed rubicund beneath the powder of his well-pomatumed hair, terminating behind his lacedaubed velvet cap in a knotty pig-tail, the buttons and gold lace of his jacket almost concealed the rich scarlet of the material, while his well-cleaned leathers fit so tight and close as to cause astonishment to the beholders how he ever got into them. The youthful Peter on the leaders looked like the rosebud to his blooming father on the box, radiant in all the magnificence of a three-cornered gold-laced hat, projecting pig-tail, bottle-nose, ponderous back, and stomach without end.

When the Duke of Blazington died, he left Peter $£ 20$ a year; and when Peter's father died, which he did in the most complimentary manner shortly after his grace, Peter got what amounted to $£ 20$ a-year more. Our friend then married the pretty head housemaid of Blazington Castle, and took the neat little hostelry called the "Grapes," midway between Plumley and Moss Side, so agreeably known to many of our readers as the first stage on the road matrimonial. This sign Peter shortly after changed into that of the "Fox and Hounds," and prosperity attending way-side speculation in those days, Peter soon found the weekly contents of his till would justify him in buying a poster that would do a little hunting occasionally. Peter used then to creep out on the sly, breeched and gaitered, with a stick in his hand. Somehow he always happened to have business in the neighbourhood of where the hounds meteither a servant to hire, a horse to look at, a pig to buy, corn to pay for, barley for malting to bespeak, or something of that sort, and being there he would just stay to see them "find." Just stay to see them find! What a charming, self-deluding sort of allow- 
ance that is. As if any man with the feelings of a sportsman within him, and the feelings of anything like a horse below him, was ever satisfied with such a snatch of pleasure as that. Nevertheless, Peter used to try it. "I'll just see them find," he used to say to himself, as he pulled out his great watch, and followed the hounds into cover, observing as he went, "there's plenty of time to ride to Wall House or Kirkland after."

Hark to Joyful! Hark! she's on the drag. "Have at him good bitch !" halloos the Huntsman, and Peter's frame shakes with emotion. Now they get together, and the old grove echoes their cry a hundred-fold. Peter presses his hat firmly on his brow, with a half sort of inkling that he may as well see them away from the cover. Now they go full swing! Reynard has run the cover's utmost limits, and dare not break. The hounds are yet "too near," as Beckford would say. The music ceases! The fox has slipped back, and the hounds have overrun the scent.

"Tallyho!" halloos the second Whipper-in from the far end of the cover, and "Tallyho" is hallooed, and re-echoed, and repeated, till every living thing is alarmed.

The Huntsman's horn goes twang, twang, twang, as he gallops through bush and briar to the halloo. The hounds strain their utmost powers to overtake him, and horses and men are in a delightful state of excitement. Peter Pigskin forgets all about the barley for malting, and settling himself as well in his saddle as shorts and continuations will allow, crams and hustles away with the best. Peter was always a man of first-class nerve, and first-class nerve makes a second-class horse go uncommonly well. Moreover, a man who is only going to take an instalment of a run-say five shillings in the pound-always thinks he may as well have it as good as he can get. Away they go over the hill, now down the vale, and 
right across Brackenburgh Meadows, pointing for Disley. The table of precedence and all the Heralds' College humbug is abolished-nerve reigns triumphant, and the majesty of horsemanship is established. In our mind's eye we see them settling into places. Well with his hounds, but not too near, is the Huntsman; then a hard-riding farmer; while Peter and the parson

\section{"Ride side by side,"}

as the song has it; red-coats come next in prodigal profusion, and we have not time to look at the tail. There's a rare scent, a slight frost in the air, and the hounds are bristling for blood-it is one of those sort of days on which the worst packs appear good.

Peter keeps his place, intending to pull up on the other side of each fence, and go and see after his barley. Somehow or other, the horse carries him over half the next field before he gets a fair pull at him, and then he thinks that being so far advanced, he may as well see what they do in the next field, until twenty minutes are exhausted, and Peter's bay is in a white lather.

Twenty minutes on paper, and twenty minutes' real riding across country, are very different things, and a check is gratefully received even by the foremost. We have seen it asserted that no man ever had the candour to acknowledge the opportuneness of a check ; but we think that all sportsmen are ready to patronize them at the proper time. It is your steeplechase gentlemen, with their cutting whips, who are always "just getting into their stride" when they occur. Twenty minutes' best pace across the country is no trifle.

Our pack, however, are at a check, the hounds having spread like a rocket, and made their own cast, now want the assistance of the Huntsman.

Peter dismounts, looks at his horse, sees all his 
shoes are on, and scrapes the thick of the sweat off with his stick. The soft horse has had a "benefit," and the sweat runs down his legs and over his hoofs. "I wish I mayn't be giving him too much," thinks Peter, eyeing his distended nostrils and heaving flanks, as he turns his head to the wind.

The barley for malting then comes across his mind, and it strikes him he's been riding away from it. "It's been a grand gallop," says he to himself, running its beauties through his mind, "I wish they'd killed him."

"Well, I suppose I must be going," says Peter to himself, laying hold of his stirrup preparatory to mounting. Just as he gains his saddle the hounds begin to feather and Peter's eye to twinkle.

"They are on him again!" exclaims he, in extacies, as gathering his reins with one hand, he brandishes his stick with the other, and spurs the well-lathered nag into a trot.

Another instant, and with heads up and sterns down, the hounds race along the hedgerow. Peter forgets all about the barley for malting, his attention being rivetted on the hounds. There are seldom two bursts in a run, and the second part exhibits their hunting qualities rather than their speed. No man innately imbued with the passion for hunting could be expected to leave hounds under such circumstances, and if Peter's mission had been ten million times more important than the mere purchase of barley for malting, we feel assured he would stand acquitted with our readers for forgetting it. Not that Peter did exactly forget it, for Dustbin, the sporting miller, declares he heard him exclaim, as his freshened hunter took a flying leap over a bullfinch and brook, "Hang the barley! I daresay it isn't worth having!"

Thus Peter coaxed himself on from point to point, now declaring he would go another day, now deluding himself that the hounds were bending his way, now 
turning his horse as if he was absolutely leaving, when, as luck would have it, the hounds invariably turned the same way, and Peter was in for it again. The story runs that Peter made nine starts before he got to his destination.

Stolen pleasures are said to be the sweetest, and we are by no means sure that a stolen hunt is not as good as any. That single day keeps the latent embers alive, ready to burst into fire under more favourable circumstances.

Not that Peter's passion was much pent up, for what with his farm and his inn, he had abundant excuses for riding in the direction the hounds had to meet. Some people ride out in the afternoon, to take their chance of falling in with them, but these are the mere feather-bed coffee-housers of hunting; Peter's business always seemed to march with the hounds. Men of business in those days were shyer of hunting and daylight amusements than they are now. Hunting used to be thought incompatible with sober tradesmanlike occupations.

That is quite a mistaken idea, however; moderately pursued, we are satisfied that hunting is the finest preparative for business that ever was adopted.

It is said that, whenever Liston, the great surgeon, had a difficult operation to perform, he used to brace his nerves by a gallop with harriers on the Pentland Hills; and all London literary men will acknowledge the refreshing obligations derived from pure air, strong exercise, and country scenery. There are some trades, to be sure, that hunting agrees with better than others; an innkeeper's, perhaps, at the head of the list. Of course a great deal depends upon the man, but, as a general rule, a good sportsman is always welcome whatever he is.

Peter's was a happy life - money rolled up, and children did the same, but the means of maintenance kept pace with the increase. He soon gave up hunt- 
ing in gaiters. All who have tried it will admit it is a most expensive amusement. He turned out a pair of old Blazington boots, which were very soon accorded the honour of ramming through all the big places first.

Thus things went on for many years; young Peters sprung up, resembling the portrait we drew of our hero on the Duke of Blazington's leaders, while Peter himself, instead of expanding into the red cabbagelooking figure of his father, receded into the little wiry old man now entering the hunting field.

IVe should state, that Peter is now what the world calls a gentleman - a gentleman in the idle acceptation of the term, meaning a man with nothing to do, nothing to do except hunt. Shortly after the railway mania broke out, the since celebrated Jeames de la Pluce, Esq. attended by his pugilistic wally, Fitzwarren, and a man in livery, drove up in a dashing chariot and four to the Fox and Hounds, and politely intimated to Peter that he was going to draw a line of railway slap through his kitchen and back offices. Jeames, who is quite the man of manners, accompanied the intimation with a hint that the company "would be appy to pay through the nose for the ecomodetion." A bait so fairly thrown out was not likely to be lost on a man like Peter, and after entertaining de la Pluce with the best of everything, he stuck the Fox and Hounds into him at three times its worth. Peter expatiated on the loss it would be to him; Mrs. Pigskin dilated on the laceration of her feelings at leaving it, and de la Pluce swept away their expostulations with sovereigns, those weighty arguments, that settle all accounts between man and man, or woman either.

Peter now lives at Rosemary Cottage, about three quarters of a mile from Fleecy Hall, where the reader may remember they first met him. Rosemary Cottage was built by a jolly bacchanalian, who having a pre- 
sentiment that he would break his neck some night going to bed drunk, built it all on the ground floor. Unfortunately, however, he sunk a well, which did his business quite as effectually as a staircase.

Peter and Cottonwool began life about the same time, that is to say, they commenced business about the same time-Peter's probationary saddle-work being struck off the account, and it says much for Cottonwool's sense that he has stemmed the displeasure of his fine, tight-sleeved, highly-flounced daughters, and stood by the "friend of his youth," as Lord Melbourne would say.

Punch says, "the retired wholesales never visit the retired retails," and we believe something of the same sort of dignity pervades country life.

In point of breeding there was not much to choose between the progenitors, Cottonwool being the son of the Duke of Blazington's saddler, his mother by a butler out of a buxom dairymaid; while Peter's maternal descent was a cross between a very respectable market gardener and a milliner.

The Miss Cottonwools, however, do not carry their inquiries into the region of pedigree; they take things as they are. Here are they, three fine, strapping, slapping lasses, with a great green coach to ride in, a sky-blue man to drive it, and another sky-blue man to loll behind, accustomed to receive the admiration of the first-class country bucks at the race and assize balls, and they cannot be expected to tolerate this dowdey old man in his drab shorts and grey worsted stockings. "Really, if papa chooses to invite such people to the house on company days, they ought to dine in the kitchen," they say.

Pigskin, indeed, according to the strict letter of right, we believe, ought to take precedence of Cottonwool, he being a retired tradesman, while our friend of the fine daughters still drives a brisk business, and discourses learnedly on the produce of Albama, 
Demerara, Carthagena, the raw article, long and short stapled. And speaking of that, it is an extraordinary thing how Pigskin and he ever delude themselves into the idea that they are driving a conversation, for the talk of one is of nothing but trade, while Pigskin's conversation runs upon horses and hunting. Nevertheless they get through their long evenings together most plainly, and each thinks the other a most agreeable man. It is quite clear, then, that similarity of sentiment and congeniality of mind are not absolutely necessary for people getting on well together in this world. We believe brandy and baccy unite more people in friendship than anything else.

To see Pigskin in perfection, the reader should visit him at home-see him when he returns after hunting, in all the joyous abandon of a good run, to his snow-white cloth, strong soup, strong ale, and beefsteak pudding. See him in his comfortable woollens and slippers, in his round-backed chair, pipe and spit box. See him in his snug room, with fox-brush bell-pulls at either side of the bright fire, sporting prints on the walls, and "Bell's Life" on the table.

The Quarterly Review Hunt, by Alken, after Apperly, that occupy the place of honour about the middle of the wall, have their story and association with the sport. Peter having come to London to see the lions, was riding loosely and leisurely down Regent Street one afternoon, after a heavy shower had rendered his namesake, Peter Laurie's abomination, the wood pavement, more slippery than usual, when his horse suddenly fell, shooting Peter Pigskin with his head heavily against a dust cart wheel. Stunned with the blow, he was carried insensible into Mr. Ackermann's well known Eclipse Sporting Gallery, and extended on the floor amidst all the sporting pictures and representations of scenes that 
living he loved so well. Every attention that kindness or surgical skill could suggest was offered; but poor Pigskin exhibited no symptoms of returning animation. At last the still pause betokening the exhaustion of all the remedies and the extinction of all hope ensued, and the lately bustling attendants gradually subsided into calm meditative spectators. Peter had not moved since he was brought in. The medical man took his leave with a solemn air, saying, he would return within an hour, the doors connecting the picture gallery with the shop were closed, and everything hushed and stilled down to perfect quiet. There, as Mr. Ackermann sat watching his unknown guest, nature gradually recovered herself, and ere the lapse of half an hour, a low, "that's very good," fell upon his astonished ear, apparently from the dead man. On looking, Pigskin's eyes were found fixed on the pictures of the Quorn Hunt, hanging on a level with his eye on the opposite wall- How long he had been contemplating them remains unknown-but the one that drew forth the ejaculation, was where "Snob" opens the gate for the good little bay horse, instead of leaping it. When the doctor returned, Pigskin was in an easy chair examining the series. The point of the story, however, is that Mr. Ackermann was so delighted with the recovery, that he insisted upon making Pigskin a present of the set. Nay he did more, he stretched them for him also. Far better than "stretching" poor Peter himself! Long may the old boy live to tell the story, and drink Mr. Ackermann's health as the kindest of men and most liberal of publishers.

Peter enjoys life, for he is not a slave to its forms. $\mathrm{He}$ rises with the sun, and goes to bed when he is tired. He gets his dinner when he comes in from hunting, and on other days he dines at two o'clock. Peter never sends out glazed or embossed cards with - "Mr. and Mrs. Pigskin request the honour of Mr. 
and Mrs. Hogslard's company to dinner," and so on, but if a brother foxhunter wants a billet the night before hunting, he is sure to find a welcome at Peter's house. So in the field; if a man is left far from home, or tires his horse, Peter has always a stall and steak pudding at his service. Peter gives him the best he has, and makes no apologies for what he does not offer. Then, when they have satisfied hunger, and drawn their easy chairs to the fire, with the little old oak table to put the bright port or black bottle with its necessary accompaniments upon, Peter will go over every inch of the run again, dilating with rapture on the performance of the hounds, and dwelling with enthusiasm on the exploits of his farourites. We are afraid to mention how many best runs in his life Peter has seen; their name is Legion.

But we are keeping the old gentleman too long on our easel. We have sketched him from boyhood, and must now finish him off as he is. There is something about a sportsman that invariably proclaims itself, whether he be clad in scarlet and leathers of high life, or the unassuming drabs and bottle-green of middle station. Peter's eye retains its fire, notwithstanding the lapse of seventy winters-we will say summers-seventy summers, for they have passed lightly over him.

The only piece of spruceness about Peter is his neckcloth and shirt; the former is of French cambric, and he has a large pleated frill to the latter. Looking at him one is strongly reminded of the old adage, "clean shirt, clean share, and a guinea in one's pocket." His drab breeches are made of uncommonly stout double-milled cloth, and his old mahogany tops are scratched and roughed till they look as if they had been rasped by the cook or the blacksmith.

Peter's horse is like himself, a wiry-looking piece of whalebone. There is not a better shaped or a better conditioned one in the field than the old 
chestnut, and his saddle and bridle are models of their order. There is as much character about saddles as there is about top-boots. It is not going beyond the mark to say that a good, well-put-on saddle and bridle make a difference of ten pounds in the looks of a horse. A London saddle will fit any horse, just as a London coat will fit anybody. What a difference there is between Peter's lean, roomy, well-shaped one, and that fat, lumpy, spongy-looking thing of Paul Poplin's. Again, look at Peter's well-cleaned, soft, thin-reined bridle, with the choke band dangling

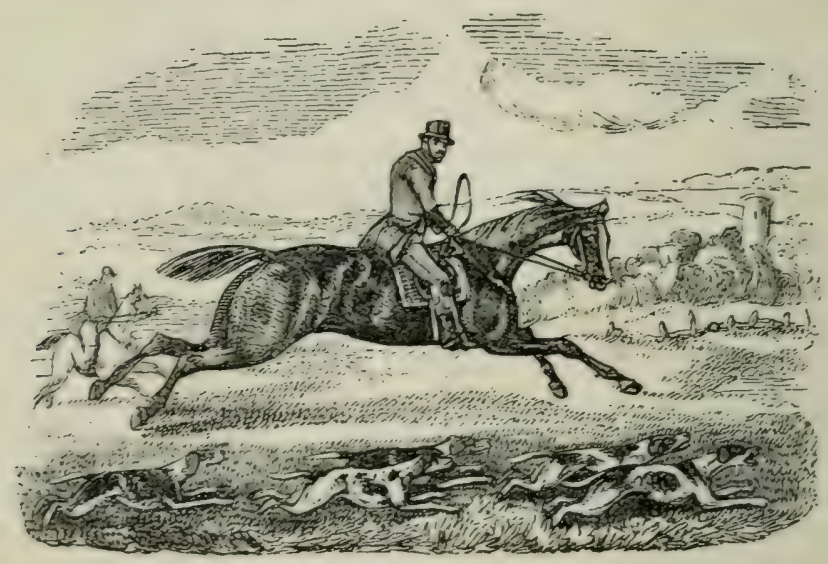

under his horse's head like a lady's necklace, while Paul's is made to act up to its name, by being drawn as tight as ever the bewildered, bedizened lad can get it. We should like to appoint Peter inspector of hunting cavalry, and get him to go round the stables and teach ignoramuses the first principles of action. Who would hire a Groom that run his choke band up to the top hole?

But enough of that, let us part with Peter. There is not a man in the hunt more respected than Peter Pigskin, and he draws his popularity from two sourceshis fine, sportsmanlike horsemanship, and his generous, 
unaffected character. No man ever saw Peter Pigskin press upon hounds. He always rides as though he anticipated a check, but when they "do run" and do go straight, when a run is established, oh, but Peter is there, imbibing delicious enjoyment as he goes. Yet he has no jealousy! He is the first to pull up, and the last to move on again. Long may the old evergreen flourish, and may many ambitious gentlemen, who it would be impolitic in us to name, take a leaf out of his book. 


\section{CHAPTER XIV}

THE FARMER

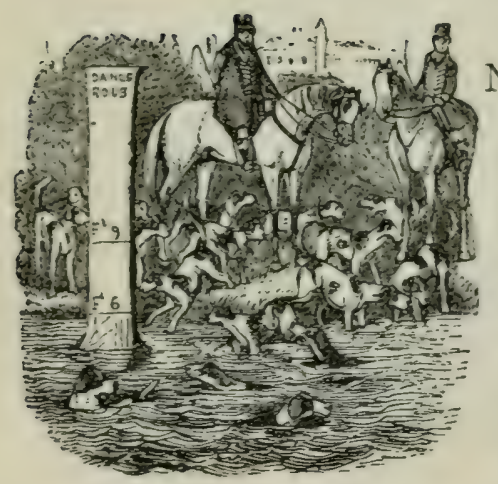

$\mathrm{N}$ estimating the position or pretensions of a member of any calling, it is important to know whether the individual in question is at the top or the bottom of the tree. Take a coachmaker, for instance: it makes all the difference in the world whether the party is a Baxter or a Leader, or one of the little shuffling, shambling shed-holders we see on the CityRoad, or in the environs of London; yet both write themselves up coachmakers, and both are doubtless entitled to the appellation. So John Slyboots, the unlicensed peripatetic packman, with his decoy ribbons and shawls, and circulars offering "equitable exchange" with servants for "household commodities" - inviting domestics to rob their masters and mistresses-may call himself a haberdasher ; but we suspect "Jones, Loyd, and Co., " or "Lubbock, Sir John W., Bart, Forster and Co.," would regard his "bit of stiff" with a very different eye to what they would the acceptance of "Swan and Edgar," or of their felicitously named neighbours, "Evans and Liberty." 
In talking of a Farmer, it is necessary to make the same sort of distinction. There is all the difference in the world between a Leicestershire or Northamptonshire grazier, or a Norfolk or Northumbrian Farmer, and the little scratchingholders-at-will we too often meet with, who seem to be running a starving match between themselves and the land, and look likely to make a dead heat of it. A Lincolnshire Farmer will have his $£ 2,000$ or $£ 3,000$ a year in wool ; and Norfolk or Northumbrian Farmers, think nothing of holding land to that amount. Yet these men, opulent and independent as they are, only rank as farmers, unless they occupy their own land, in which case they combine the title of Esquires.

The dictionaries, from which we authors draw half our apparent knowledge, say that "to farm, is to hire, or take upon hire; to hold or take, for certain rents or sums to be rendered, or other considerations required or performed; to let land or other property on such conditions; to till, or cultivate land;" so that the payment of money seems to draw the line between the Farmer and the farming landowner, or what is commonly called an Esquire.

Most of us have some sort of outline in our mind's eye of the human form divine filling the various occupations of life, and the word "Farmer," we should think, generally suggests a large drab coat, with flap pockets, patent cords, drab gaiters, and double soles. The term "Gentleman-Farmer" suggests a green cutaway, with white cords, and topboots. The Gentleman-Farmer, we should imagine, was merely a refinement, or buck of a Farmer-not a landowner occupying a certain portion of his own land, though some of these we see write themselves up Farmers at the backs of their gigs and dog-carts.

Taking the word "Farmer," however, in its general and comprehensive sense, it is suggestive of more 
innocent if not more poetical associations than any other title we know of. It is the "love in a cottage" of industrious life. We who live in smoky, foggy, pent-up London, to whom Primrose Hill or the treeclad heights of Hampstead are a luxury, sigh for the enjoyment of our own cow, and a shady flowerstrewed pasture to feed her in. What pleasure to turn an old fat hen off her nest and pick out our own warm egg-to shake the thick reluctant cream from the spout of the well-filled jug. How delightful to wander in the flower-garden, amid the hum of our own bees, all at work for our own profit-to see our own ducks scudding over our own pond, and instead of the carrier pigeons of Islington and Holloway, to see the wheeling flocks alight on our own white dovecote. Above all, picture the enjoyment of the sunny hay field, with coatless men mingling with the merry maids of the village green.

Farmers are about the only people exempt from any settled denunciation on account of their calling. We hear of savage soldiers, rascally lawyers, humbugging parsons, greedy tradesmen, grasping doctors, exorbitant coachmakers, ruinous milliners, but the worst accusation we ever hear brought against a Farmer is that of doltishness or stupidity. That is a last "refuge of the destitute" sort of charge, answering to the "ugly old cat" of the ladies, or the schoolboy's objection to Dr. Fell :-

\section{"I do not like you, Doctor Fell, \\ The reason why I cannot tell; \\ But this I know full well, \\ I do not like you, Doctor Fell."}

"You are a thick-headed farmer, and that's the long and short of it," as a friend of ours would say, in closing what he would call an "argument."

To appreciate a farmer properly, it is necessary for a person to be acquainted with country as well as 


\section{THE FARMER}

with town life. He will then be able to draw a just estimate of the quiet, respectable loyalty that pervades the whole class, and contrast it with the hurried, self-interested excitement and elbowing that characterises the gatherings of large bodies. There is something at once substantial and respectable about the yeomanry of the kingdom, if we may so designate all the landholders who are qualified to vote for knights of the shire, instead of the 40 s. freeholders of former times.

The "yeomanry of England" has always inspired in our landsman's mind the sort of feeling that "Ye Mariners of England" rouses in that of the sailor. We look upon them as one of the main-stays of this country.

If there is one class of men, however, who can more properly appreciate the spirited liberality of the farmer than another, it is foxhunters; above all, foxhunters, who themselves are also farmers. We do not mean foxhunting farmers, but farming foxhunters ; country gentlemen, who keep a small quantity of land in their own hands more for amusement than profit-perhaps. These are the parties who can best enter into the feelings and appreciate the forbearance of the real farmer, whose means of livelihood depend on the well-doing and produce of his crop. Let the squire picture to himself his feelings at seeing the well-ploughed, well-worked, well-manured, well-watched field of young wheat, that he has boasted of the expected produce of to all his neighbours, counted as so much gold, nay, perhaps, held up to the admiration of his local agricultural society-let him picture to himself his feelings, we say, at seeing this beloved spot crossed diagonally by a field of fifty horsemen, followed by a score of boys on ponies, whose rear is brought up by a herd of cows or Scotch cattle, that sweep round the enclosure before they can be got out! 
How long will it be, we should like to know, before he would muster resolution to take a cool survey of the spot, and look with indifference on the varied footings of the horses and the cattle? yet this man is a foxhunter himself, to whom farming is a secondary object; how much stronger, then, must be the feeling of the man who is no foxhunter, and whose sole dependence is on the produce of that trampled soil.

Take a field of turnips - what havoc and destruction a field of horsemen make in smashing through its contents! Not only what the horses absolutely knock out of the ground and destroy, but every turnip they hit is more or less injured, especially if there comes a frost. We must say, and greatly to their credit we say it, that it really is astonishing the damage and inconvenience farmers put up with every year, and the extraordinary good grace with which they do it. It is not the grumpy, passive acquiescence, that looks- "I'd break your head if I durst" - but the sheer downright permission to do what the exigencies of the sport require. All farmers stipulate for is against "wilful damage," and most justly are they entitled to what they ask. Nothing can be more annoying to the true sportsman than to see wanton or unnecessary mischief; crushing young quicksets for the sake of a leap, letting cattle escape for want of shutting the gate, or any of the numerous acts of omission or commission that all go to swell the catalogue of damage.

Some townspeople have not the slightest idea of the damage they do, indeed many of them do not seem to think it is possible to do more harm to one field than to another. There's our friend John Chub, the ironmonger, of Camomile Street, who goes pound, pound, pounding, straight as an arrow, whether hounds are running or drawing, just as he would clatter about among his fenders, fire-irons, and 
hardware. Chub means no harm, indeed there's no better man-regular at church, punctual at business -kind to his wife, ditto his children, pays the income-tax without more grumbling than his neighbours, never keeps the rate or tax-gatherers waiting, and if he only knew when he was going to do harm he would never attempt it; but somehow Chub looks upon the country as a sort of enlargement of Hyde Park, over which a person is at liberty to go any way he can get. True, Chub never attempts the wall or the rails of Kensington Gardens, but that is only because he sees they are too big; so it may be said he never rides at the Grand Junction or Paddington Canal, but whatever Chub sees at all "upon the cards" he looks upon as fair and proper game-nay, as something that he ought to have a shy at. Nothing short of the fear of a broken neck can turn him to the right or the left.

So with Paul Poplin-Paul has not the slightest idea of going out of his way for anything except a toll-bar, which he shirks, to aroid paying; and he thinks a red coat would justify his riding into a lady's drawing-room if he liked. Gardens he looks upon merely as small enclosures-fields on a small scale"retail" ones, as he calls them. Paul has heard of a "bull in a china shop," and it is just to a china shop that Paul's ideas of a bull's capabilities of mischief are limited. He can fancy the consternation the animal would create among the jugs and basons, but as to thinking it could make the slightest difference to a Farmer whether the animal was in his own close or a neighbour's, Paul thinks if he got into the neighbour's it would be so much the better for the owner, as he would get fed for nothing.

It is only the real sportsman, or person who takes part in the management of a country, that can be fully sensible of the obligations foxhunters are under to Farmers. In the first place, we are indebted to 
them for the existence of the animal we hunt; and their sufferance, nay, protection of it, is the more disinterested and meritorious, inasmuch as foxes cannot by any possibility do Farmers any good, but, on the contrary, are almost certain to occasion them loss and inconvenience. They, in fact, harbour animals for their own inconvenience. This they do, too, in spite of domestic grievances and expostulations, for foxes occasionally make sad forayes among the poultry, and it would be extremely difficult to convince a Farmer's wife that a hare was not quite as good an animal to harbour for the purpose of hunting, and a much better one for the purposes of the table. It may be said that harriers go three times over the ground for the fox's once, and granted they do, still they do not go over wheat, or ground on which they can do damage; at least they "didn't ought to do," seeing the case is never one of urgency. But, with a flying, straightrunning fox, with a burning scent, and main earths open in an adjoining country, so far from caring for wheat, we believe a field of foxhunters would ride over the great Lord Mayor himself, and all the court of aldermen, if they came in the way. It may also be said that Farmers enjoy the sport themselves as much as any one out, and we grant those who come out do; but for one Farmer that hunts, there are five hundred that do not. Recent times have not been favourable to the race of Foxhunting-Farmers, and many, we fear, are dismounted. Besides, those who do hunt are generally the top-sawyers of the trade; whereas, in many countries, the preservation of foxes may be quite as much dependent upon a small Farmer who has not the means of hunting, as upon a large holder.

A favourite argument in favour of Farmers encouraging foxes and foxhunting, has always been the advantage they derive from the consumption of hay, oats, straw -farming produce generally - and the opportunities 
it affords for selling their horses to advantage. These arguments are plausible enough, but, like many plausible ones, are destitute, or nearly destitute of truth. There is no doubt that the standing of large studs, such as we saw congregated at Melton, Leicester, Leamington, Cheltenham, Coldstream, and other places, must cause a considerable consumption of the enumerated articles, but the extra profit goes into the pocket of the middleman, and not into that of the Farmer: corn-chandlers, inn-keepers, liverymen, saddlers, are all benefited, and many of them very largely; but what the bona fide Farmer gets is seldom more than the mere market price, with the accommodation, perhaps, of a near, instead of a distant delivery for his produce.

As to selling horses to advantage, that is a point involving so many contingencies, that we fear even the most sanguine dare hardly look the matter fairly in the face. Good stock, good luck, good keeping, good handling, and though last, not least, good riding. The only way we think that breeding can pay is where the breeder hunts himself, and can show his horse off to advantage. Even then a great deal depends upon whim and caprice. One man can sell anything, and get almost any price, while people will hardly look at the horse of another. The riding is, perhaps, the most important point, and there are not many men with both the nags and the nerves equal to the task.

Taking the average of countries, we believe it will be found that a Farmer is generally the best man in the majority of hunts-either a Farmer or a parson, though rigid discipline has thinned the ranks of the latter. A Farmer, however, is generally the best man, and, in stating this, it must be remembered that they generally give a good deal away by riding unmade and oftentimes moderately-conditioned horses.

"Upon the w-h-o-o-l-e," as Farmer Wopstraw says 
in "Hillingdon Hall," we are inclined to think if it were not for the innate, national inclination for hunting implanted in Britons, Farmers would find the preservation of foxes and the promotion of hunting a very poor speculation for anything they can get by it in the way of money.

The importance of standing well with the Farmers is a matter so perfectly understood by all Masters of Foxhounds, as to require no enforcement at our hands. If a Master has not the goodwill and support of the Farmers, he need never attempt to hunt a country. Farmers have always been considered worthy the regard and attentions of all authorities on hunting. The great Mr. Meynell, it is said, used to arrange a day in each week to suit the convenience of the graziers attending their market, and Mr. Corbet used to show the Warwickshire ones similar attention.

Colonel Cook, in his work on foxhunting, speaks of the Farmers in the countries he had hunted in the highest praise, and in enforcing the importance of hunting the good and bad parts of a country alternately, he says, that although Farmers are liberal, they think it hardly fair play, if they rent a farm in the best part of the hunt for sport, to have their land rode over constantly, whilst in the other less favourable part the hounds never meet. Their conversation, says he, "at the market dinner, over a bottle, is often on this subject, whereas if you do but hunt the whole country impartially, there can be no cause of complaint."

Mr. Smith eulogizes the conduct of the Farmers in all the countries he has hunted, and urges that every attention and consideration should be paid them. There is a story told of M.r. Smith, we forget whether in his book or not, that when he had the Craven country, and was in the habit of cub-hunting in Marlborough and Savernake Forests in the autumn, that a fox broke and took through a field of wheat, and on riding to stop the hounds, a young Farmer 
came up and begged he would ride through the wheat, adding, "his father would be very much offended if he did not."

Indeed it has been frequently observed that Farmers are generally the first to ride over their own wheat. An amusing instance of this is related by Nimrod in his northern tour. A nobleman's Huntsman was blowing somebody up for riding over a field of wheat, who not attending to the rate, the Huntsman launched out again with something stronger. Still the man paid no attention. The Huntsman "at him" a third time, adding the inquiry if he didn't know he was riding over wheat?

"Well," replied the Farmer. "It's my own!" thinking to silence the reprover with the information. "So much the worse," retorted the Huntsman, adding, " there's the force of example."

Farmers are the most easily pacified and soonest satisfied race of men under the sun. The smallest kindness, the smallest attention, the smallest consideration, is never lost upon them. Let a Master of Hounds only show that he is sensible of any damage he may have done them, or of any accommodation he may have received, and they do not know how to stop the expression of his thanks soon enough. It is in these sort of trifles that Masters of Hounds show their tact and management. We have seen some Masters desperately uncouth with the Farmers, taking no notice of them either at the meet or the finish. Others again have always something polite or good-natured to say, and a felicitously presented "brush" has atoned for the tramplement of much wheat. IVe remember when it used to be a favourite topic of discussion, whether riding over wheat did it harm or good, and we have seen stout pen and ink champions in favour of the system, but, like many plausible things upon paper, the theory and practice are very dissimilar. It is quite clear that Farmers do not 
think so, otherwise they would turn their cattle in to their wheat fields.

In some countries Farmers' cups are given, to be contended for by the horses of Farmers in the limits of the hunt, and certainly, as a mark of gratitude and attention to this most praiseworthy class of men, it is a tribute deserving of commendation, but we almost doubt whether the prizes generally reach the objects the givers would like to see them go to. In the first place, hunting and racing are such totally different amusements, that one seldom sees a taste for both combined in the same person, added to which, Farmers, least of all people, are likely to cultivate an inclination for both, and if a man keeps a horse for the cup, it is not very likely that he will keep him for the legitimate purposes of hunting. Hence these prizes too often fall into the hands of itinerant blacklegs and leather-platers, or men in league with some skirting, nicking, road-riding, fox-heading fellow, who is always getting among the hounds at the death, or grinning in the Master's or Huntsman's face at a check, to draw their attention to the fact of his being up.

If we could be certain of seeing these trophies go into the hands of the real Foxhunting Farmers of the hunt, if we could think that each succeeding year was adding a fresh rivet to the chain of foxhunting, by drawing the recipient in closer union with the members of the hunt, nothing could be more desirable than the encouragement of such prizes; but when, instead of their going to grace the sideboard of some true lovers of the sport, to show by their inscription to their descendants and friends that their zeal was appreciated and rewarded, they fall into hands who merely value them for their weight, and who are ready to sell their unprized prizes for the next year's contest, it raises a question whether some more suitable acknowledgment could not be devised that should be exclusively 
beneficial to Farmers, and incapable of diversion from the right course. Prizes for the best colts or hunters bred in the limits of the hunt, prizes for the best sheep, or indeed for anything exclusively in the province of Farmers, might, we think, be advantageously substituted, especially now, when every district has its agricultural association or Farmer's club.

We like to see a good lot of Farmers in the hunting field. People may talk of the Excise and the Stamp Offices, indicating the prosperity of the country, but to our minds, there is nothing so convincing as seeing plenty of Farmers out hunting. Farmers are not improvident people; they live too retired to be improvident, and it may be laid down as a general rule, that no man who communes much with himself will ever be so. Extravagance and improvidence are engendered by contact and crowds; one man leads another astray, and having embarked in a thing few men like to back out. But Farmers are not gregarious beings. Society with them is the exception, and not the general rule. The family circle supplies their wants in that way, and a domestic man will rarely be found doing an act prejudicial to his family. When times are adverse, then Farmers do not hunt, and therefore we hold that a good show of them is the most satisfactory evidence of general national prosperity.

We hope to live to see farming occupying a higher position in the enterprise of our country than it at present holds. Not but there are many bright ornaments among its peaceful followers already, but we hope to see farming taken up more as the occupation of gentlemen, who will adopt its fine, healthy, interesting pursuits, instead of some of the genteel starvations called "professions," that many waste the best of their lives in following, to quit in disgust at the time they ought to be making money. Farming is 
not a money-bag loading business, like many sedentary trades and pursuits, but then it is a certain means of good and comfortable living, and requires no long slavish apprenticeship, or extraordinary power of intellect to learn, and no great capital to set up with. Suppose a parent can give his son two or three thousand pounds, to set him up in a farm of from eight hundred to a thousand a-year rent. For that he gets a good house and garden, and his farm will furnish him with every real requirement-not to say luxury of life, and instead of imbibing the foul, noisome air of the town, in some confined chamber or manufacturing office, and getting snatches of life by occasional dives into the country, his whole year is one of wholesome, pleasurable excitement and enjoyment. To a lover of the country no life can compare with that of a Farmer. He enjoys from youth to age what others slave and toil in hopes of reaching at the end. Farming is the nearest approach to primitive independence of any calling we can adopt. The Farmer is his own master, and though he may not derive so large an apparent income as the investor of money in, or follower of other pursuits, yet when we come to see what the Farmer gets for nothing, that others have to pay for, and observe how one thing dovetails in with another, it will be found that after all, the enjoyments of life are not regulated by the figures in three ruled columns of red ink, but in making the most of such advantages as circumstances afford and put in our way. Take a horse for instance-a Farmer will keep a horse well for five-and-twenty pounds ayear, whereas the Londoner will have to pay his guinea a-week for the keep of his, and then very likely only have it half "done by." There is cent. per cent. at once, and there is much the same difference in the price of articles of domestic consumption. To talk of dining with a Farmer is enough to set a Cockney's mouth watering for a week-the very mention of the 
thing conjures up all sorts of anticipations of pure, wholesome, rich, abundant excellence. The prime home-fed beef, the dark graveyed mutton, the cleanfed pork, the plump white turkey, the delicate chicken, the beautiful ham, the mealy potato, the scarlet beet, above all, the fine, bright, home-brewed October, and home-made butter and cheese. A large farmhouse is a sort of general provision warehouse, containing the genuine, unadulterated article. Who ever got a snack of anything at a farmhouse without thinking it excellent? Who so truly hospitable as the Farmer? $\mathrm{He}$ gives what he has freely and heartily, and never apologises for the absence of what he has not. Who ever hunted in the midland counties without retaining a gratified recollection of the excellence of the Farmer's pork-pies? The Lewes sausages of former days will still smack on the palates of many. Again, what place so sweet, so enjoyable, as a dairy. If people would but be satisfied, and make the most of what they have, instead of yearning after what they have not, no mercantile trading life could compare with that of a Farmer. The glittering uniform may delight the boy, but the easy coat of the country resident, the roomy house, above all, self-mastery, present attractions that no gaudy outward show can compensate for the want of. Though we hear of few large fortunes made in farming, we seldom see a Farmer in "The Gazette"never almost, unless he has been speculating in something he ought not. Railways, perhaps.

But let us take a glance at a Farmer in the hunting field. The jolly-looking chap turning in is Mr. Barleycorn, of Verdon, one of the old school of Farmers; he is mounted on one of the old stamp of hunters. Horse and rider are very much of a-piece, big, boney, lasting looking articles. The horse is twoand-twenty years old, and though old "Corn," as they call him, rides fifteen stone, and is generally first to come and last to go, there is no blemish or symptom 
of decay about the nag. Barleycorn and his friend, Michael Brownstout, of Sapcote, keep a pack of harriers between them, but when the foxhounds are near they give the preference to them. Barleycorn has farmed in good times, bad times, and middling times, but in whatever times he has farmed his heart has always been in the right place, and he has never given way to despondency or fear. Fear forsooth! look at his frame; there's a fist that would fell an ox. He d-ns Peel, but only because he considers Peel "did him." He's not a bit afraid of what he calls the

\section{Mouncheers.}

Barleycorn, to our fancy, is one of the happiest of men. He is rich-rich in the fewness of his wantsand has nearly all the requirements of life within himself. A good, large, roomy, well-built, old fashioned farm-house, with attic windows peering out of the stone roof, a comfortable parlour on either side of the entrance, and the kitchen sufficiently near to make the knocking on the table with his knife answer the purpose of a bell, to indicate when he is ready for the second or third steak and the pudding. $\mathrm{He}$ has a nice, clean, heaithy-looking girl to wait upon him, and a managing body of a wife to look after the girl and the interests of the dairy and larder as well. Barleycorn hunts his twice a week, and has always hunted his twice a week, and means to continue to hunt his twice a week, and yet he has only the big nag under him, and an old brood mare, that takes her turn about the farm the day after a hard run or a long day. His friend, Brownstout, is a sort of double, both in size and dress, and, when their backs are turned, it is hard to say which is which. Having great confidence in each other's judgment, they generally buy in "duplicate," thus, if Barleycorn treats himself to a new beaver, he buys another for Brownstout; and, some people say, that after a "wet night" or two, the hats become common, and they just take either. Both 
their Christian names being John, and their surnames beginning with a " $\mathrm{B}$," perhaps aids the confusion or commonalty. Their thunder and lightning coats are cut off the same web, and made up by the same snip - $\mathrm{so}$ are their waistcoats, ditto their big-ribbed cotton cords, as the dangling drab ribbon over the mahogany tops testify. This similarity of dress is often seen in the country; indeed, in the hunting field one may sometimes tell the residents of particular districts by their clothes.

In hunting, Barleycorn and Brownstout are equally

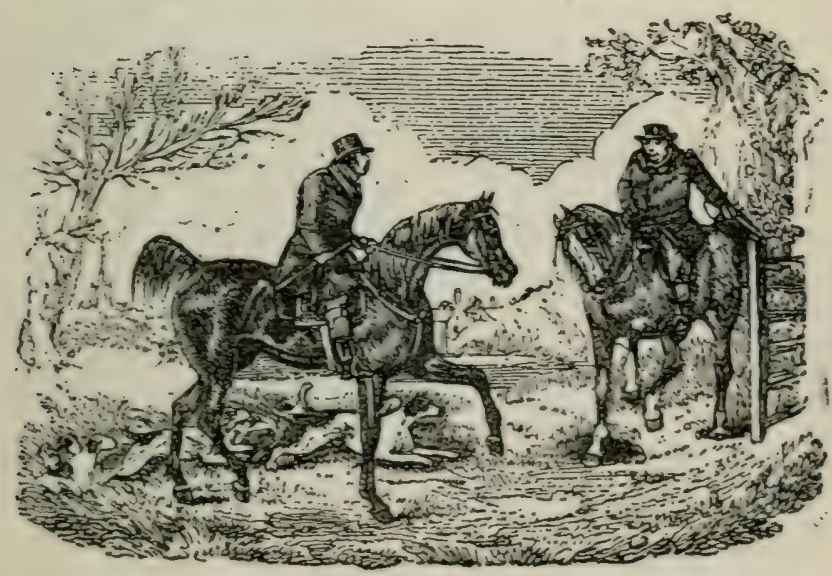

unanimous, both being admirers of the silent system. They hunt by the weather, and not by the card. If Monday is a bad day they turn out on the Tuesday, or adjourn again till the Wednesday, the Sabbath and market-days being the only ones to avoid. It says much for their management, that under whatever Master the foxhounds have been kept, Barleycorn and Brownstout have never been accused of interfering with their sport; on the contrary, they have received the repeated expression of the thanks both of Master and followers, for their preservation of the "varmint." At the present moment, we may add, 
that there is a duplicate round of cold beef at each of their houses, in case the hounds should happen to pass either way. As we fear our numerous engagements will prevent our partaking of either, we shall now bid adieu to our good friends the "Farmers," regretting our inability to portray them in the bright colours we could wish, but, assuring them at the same time, of our hearty appreciation and unfeigned respect. 


\section{CHAPTER XV}

ELIJAH BULLWAIST, THE BLACKSMITH

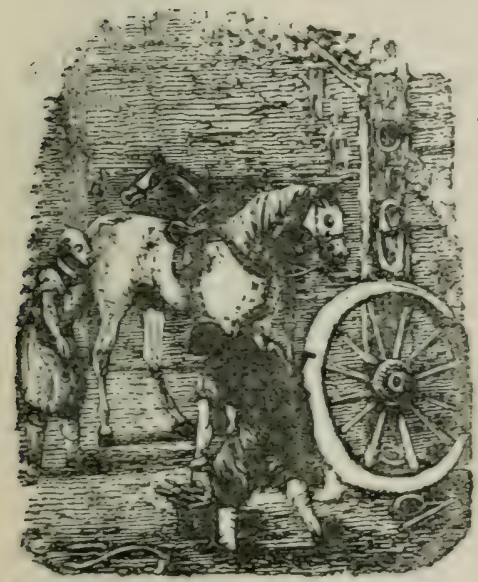

ASTING our eye over the field, the next character that greets is one of whom we before spoke -Elijah Bullwaist, the Blacksmith. Were it not for the shagginess of his pony's coat and the redness of Bullwaist's nose, some apology would be due for keeping them so long; but neither is likely to take harm by standing. Bullwaist is rightly named, for he is a man of Herculean proportions, six feet two in his stocking feet, broad shouldered, broad backed, and big limbed. How he ever can have the conscience to pile his ponderosity upon that poor, ill-fed, hard-worked, white pony, passes our comprehension. Surely none of the "notables" for the suppression of cruelty to animals can have heard of his performances, or Mr. Thomas would have been after him, "Dicky Martin" in hand.

It has always appeared to us that the old school of blacksmiths are as much a distinct class or breed of men as coachmen, sailors, or Jews. To our mind 
they are a sort of cross between a travelling tinker and a stableman-by Vulcan out of Pitchfork, or something of that sort. They are almost all sportsmen or sporting men-that is to say, they have a turn for everything going, or can turn their hands to everything. They like a hunt, and they like a race; they like a game at pitch and toss, are great at quoits, can play at cards, dominoes, get up raffles, shoot matches, jump in sacks, bait badgers, and don't care if they go out coursing occasionally. Like the travelling tinker, they generally have a turn for keeping a horse. "Keeping," indeed, we can hardly call itstarving, starving a horse would be nearer the mark. Bullwaist's pony is a sample of that. Its shape is good, but it is long "overdue," as the bankers say, only there is nothing on it to make soup of. Yet the poor beast was in the coal cart all yesterday, and was assisting at a moonlight flitting the night before. Now it has seventeen stone, avoirdupois weight, piled upon its back. Bullwaist is a hard taskmaster. He never thinks he can get enough out of a horse.

The blacksmith's shop is to the country what the saddler's is to the town, the grand emporium of news. It is to the servants what the hair-dresser's is to their masters, or perhaps their mistresses, for we will give our sex credit for having something else to do than gossip. When the Blacksmith combines the trade of publican as well, it will go hard if he is not acquainted with all the "inns and outs" of the country. It will be odd if he does not know who was at the castle last week, and who is expected next; nay, we will be bound to say he can tell who supplied the Dorking fowls, and what butcher sent the most beef and mutton. He has a chronological chart in his head of all the kings and queens that have reigned there since the days of his boyhood; can tell what butler king was most liberal with the beer, and what 
key-carrying queen was most lavish in the larder. Nothing, perhaps, can equal the gossip of a publichouse keeping country smith, and we often wonder at gentlemen tolerating such nuisances on their estates. They are the ruin of servants, and the general haunts of idleness. It is an odd thing, but let the beer be ever so good and strong and plentiful at the castle or the hall, the servants will draw to the public-house to spend their own money in trash. As this cannot be for the sake of the drink, it must be for the sake of the gossip, and let any tolerator of such a nuisance picture to himself what the conversation is likely to run upon. We have seen many a lazy skulking dog dragging his legs along to the public-house, who could never "find time" to go to church.

With gratitude we say it, the Royal Veterinary College has done much to eradicate a breed of men who were at once the curse of horseflesh and the country, and in lieu of the botching, bungling, ignorant, self-sufficient, drunken, daring, kill or cure, fear nought horse and cow-leeches of twenty or fiveand-twenty years ago, we have an educated race of men, combining the business of shoers and veterinary surgeons, who can be called in when a Groom or Master's knowledge is exhausted or insufficient. In consequence of the distribution of veterinary surgeons through the country, we have got a better set of working smiths-men with some idea of the anatomy and delicacy of a horse's foot, and not fellows who cut and wrench and hammer and tear, as if it had no more feeling than a vice or an anvil. Londoners have no idea what an old country smith was like; they would do anything - set a limb, shoe a horse, make a key, mend a gun, sharp a ploughshare, or prescribe for horse, dog, cow, and even man. The division between whitesmith and blacksmith is still unknown in the greater part of the kingdom.

Few libraries are without that useful work, "The 
Horse," 1 written by Lord Brougham, and a select party of sportsmen (Mr. Leader, most likely, and others), and published under the superintendence of the Society for the Diffusion of Useful Knowledge-a work that contains more really useful matter in an easy, unpedantic, intelligible-to-the-meanest-capacityform, than any that we know of ; and were it not for the tendency it might have to lead ignorant fellows to experimentalise on poor horses, we could wish it were in every saddle-room as well. That, perhaps, not being desirable, we may quote a passage on shoeing that is incapable of perversion, and well worthy the attention of masters, servants, Bullwaists, and all -if such bigoted creatures as Bullwaists are open to conviction:- "We will suppose the horse is sent to the forge to be shod," says Lord Brougham and Co.: "If the master would occasionally accompany him there, he would find it much to his advantage. The old shoe must be first taken off. We have something to observe even on this. It was retained on the foot by the ends of the nails being twisted off, turned down, and clenched. These clenches should be first raised, which the smith seldom takes the trouble thoroughly to do; but after going carelessly round the crust, and raising one or two of the clenches, he takes hold first of one heel of the shoe, and then of the other, and by a violent wrench separates them from the foot, and by a third wrench, applied to the middle of the shoe, he tears it off. By this means he must enlarge every nail hole, and weaken the future hold, and sometimes tear off portions of the crust, and otherwise injure the foot. The horse generally shows by his flinching that he suffers by the violence with which this preliminary operation is performed. The clenches should always be raised or filed off;

I Here let us recommend Mr. Miles's treatise on the foot of the horse to the especial attention of sportsmen and horse masters generally. It is a most sensible work. 
and where the foot is tender, or the horse is to be examined for lameness, each nail should be partly punched out. Many a stub is left in the crust, the source of future annoyance, when this unnecessary violence is used."

His lordship shows himself to be an accurate observer, and to have profited by his sporting pursuits, albeit followed in France, not the likeliest country for sporting science. No doubt the horse does flinch-nay, we have heard them give a sort of groan, not unlike the sound emitted by a man catching up his foot on having his corn trod upon.

The man-shoer and the horse-shoer occupy similar stations in the biped and quadrupedal world, though the latter have, perhaps, the best of it, in their exemption from the abuse invariably lavished on a misfitting, uneasyfitting "snob." Let a man think of the misery he has endured from the uneasy, uneren pressure of a tight boot, and he will surely have some consideration for the comfort of his horse. There is in horseshoeing precisely the same discomfort, without absolute lameness, that there is in human shoeing, and it is that discomfort that a careless, off-hand sort of fellow never discovers. A man with a head, and eyes in that head, can see by the way a horse stands in his stall whether he is comfortable or not; but many fellows will get on their backs and ride them eight or ten miles without feeling that they are not going in their usual form, which a master discovers the moment he mounts. These are the cast-iron, woodenheaded class of servants, "Grooms" we will not call them, who have no more feeling or sympathy with horses than hedge stakes. They go lob, lob, lobbing along without thought or care, save how to get there, and how to get back. Notwithstanding the great improvement that has taken place within the last twenty years in the style of country blacksmiths, and the manner of country shoeing, there is still ample 
room for further advancement. There is still as much difference between the skilfully town-shod horse, and the lumpy, heavy, graceless, iron-bound hoof emancipated from the hand of the country shoer, as there is between the Bartley turned out boot, and the shapeless, baggy, half-tanned leather looking things of John Crookedlast, of the village of Clottington. There is as much difference in iron as there is in leather. A set of shoes from one man will last half as long again as a set of shoes from another man, just as a pair of boots from one man will outwear two pairs from another. We have seen stuff put on for iron that was almost as soft as gingerbread, driven in by great tenpennymail-looking things, whose fat unburied heads looked as if they were meant to act the part of one of Crosskill's clod-crushers; regular tear-up-the-land and soil-looking things.

It is not our intention to discuss the merits of the different forms of shoes, but there is one point connected with hunting shoes that merits a word or two, and that is "calkins," or turnings up of the heels, to prevent slipping. These are very useful in downy, hilly countries, and if the calkins could be added on arriving at that sort of country, they would be very good, especially in frosty weather, where, as all Sussex sportsmen know, one side of a hill is often soft and the other side hard, according as they lie to the sun. Some turn up the outer heel only, and on soft greasy surfaces, perhaps, the outer heel is sufficient, but as that causes uneven treading, it must be prejudicial to the foot on roads and hard surfaces. If calkins, therefore, are used, they should be used to both sides of the heel, or the foot either raised up or pared down, so as to preserve an equality.

There is another very important point connected with shoeing, particularly hunter shoeing, that even our friend Lord Brougham and the whole "Useful Knowledge Society" seem to have overlooked, and 
that is nails. The best and neatest of shoes are useless without good nails, just as the best and neatest of biped ones are useless without strings or fastenings of some sort. Now it is a notorious fact, though we dare say Elijah Bullwaist will deny it, that the same man cannot make both shoes and nails. Bullwaist will make what he calls nails just as he makes what he calls shoes, but if any of our readers will pop into a veterinary forge, or well-conducted smithy, he will find making nails and making shoes are distinct departments, nay, in many, that making nails, making shoes, and putting them on, constitute three separate branches. Let the shoes be ever so good and ever so well put on, it is clear that they are of no use, especially for hunters, unless they will stay on, and that staying on depends almost entirely upon the make and quality of the nails.

We do not know a more graceless, thankless office, than telling a man he has lost a shoe, particularly if the discovery is made in the middle of a run. We wonder if any person ever got thanked for such information. Shoe losing is one of the drawbacks upon foxhunting, and one of the greatest arguments for the second horse system. A man with a second horse looks at his nag's feet at a check with very different feelings to the man who has merely a spare shoe at his saddle. The man with his Groom behind him with a second horse can afford to be civil when he is told he has lost a shoe: he has nothing to do but change horses, just as he would change his plate at dinner. But the man with but one horse, no spare shoe, and no knowledge of where a blacksmith is to be found, has a very dejected melancholy air as he turns from the hounds and rides about among the country people, asking if they can tell him "where to find a smith?" Shoe cases are now so common that the exception is seeing a saddle without one, and there are divers patent contrivances extant for self- 
fastenings and self-adjustings, that might be very useful if the patentee was in attendance to work them, but which had better be discarded in favour of the common shoe, with a few nails to set it on with.

What an unfavourable opinion of foxhunters any one would draw who merely saw them arrive at a blacksmith's on losing a shoe in the middle of a run. To heighten the loser's chagrin, after seeing all his lovely companions gradually disappear, when at length, horse in hand, he arrives at the pointed out spot, it's ten to one but he finds the shop empty, the blacksmith after the hounds, and the apprentice shading the sun from his eyes with his hand on the top of a distant wall, straining his sight after the pack. Then when the unfortunate sportsman does get a creature to attend his behest, what gaping, poking, and searching after what they know they have not, work there is; what fumbling of dray-horse shoes, and measuring of donkey ones, to see if they will fit. The eye seems useless to some fellows, they are never satisfied a thing won't do, until they measure it. If a man has not a shoe with him, the only plan is to get the best fitting old shoe the shop will afford put on. Don't let the fidgetty sportsman hurry the man, or he will most likely drive a nail into the quick. Let "patience" be the word, and if on getting the horse to the door, and leading him on a few yards, he walks sound, let our sportsman remount and see if a lucky check or turn will not let him in again.

Some people are very easily "cowed" if we may use such an expression in connection with hunting, on losing hounds, and never attempt to catch them if they once get away from them, or to fall in with them again after getting a lost shoe replaced. Instead of doing so, they indulge in all sorts of imprecations, and conjectures as to the splendour of the affair they are losing. A pack out of sight are always supposed to be going best pace, whereas, perhaps, they are 


\section{THE BLACKSMITH}

pottering on the other side of the hill, picking the scent over fallows or cattle-stained ground. A hunt is not like a steeple-chase, where a few minutes make all the difference. We have seen a man lose a shoe, find a smith, get another put on, and jump in with the hounds running back with their fox as he led the horse out of the door.

Some people are desperately inquisitive about a horse's health, temper, appetite, and peculiarities, asking no end of wise questions, and taking no end of precautions, and yet we dare say it never enters the head of one in a hundred to ask if he is a shoethrower. Some, we dare say, will smile at the idea, because such a blessing as a shoe-thrower has never fallen to their lot. We remember some years ago being in a party of foxhunters, where the productions of a hunting contributor to one of the sporting magazines was under discussion, and a gentleman observed that he did not think the writer could be a man of much experience, because he spoke of a piebald hunter in the field as a curiosity, whereas, said the speaker, "piebalds are quite common in our country." So we are all apt to argue from what we ourselves know. This gentleman lived in a country where there was a famous piebald stallion, but we may appeal to our readers whether a piebald horse is not an unusual sight in the hunting field. But this gentleman thought not, and we have the same sort of idea, that shoe-throwers are not so uncommon. Of course all horses will cast their shoes occasionally, but there are some that make a point of doing it at the very earliest opportunity. Indeed we are something like the gentleman who lived in the country with the piebald stallion-for a friend of ours once bought a finely shaped white horse at Tattersall's, perfect to look at, fast in his gallop, temperate at his fences, but who invariably pulled off a fore shoe before he had gone over half-a-dozen leaps-nay, we 
have known both shoes come off together. And yet there was nothing the matter with the horse's feet; they were good, sound, healthy feet-he did it by catching the hind shoes with the fore, and no contrivance or ingenuity could prevent his doing it. Now that is a case "in point," as the lawyers say, and though we admit the occurrence is a rare one, still we think that question might just as reasonably be asked as half the questions that are put about hunters.

Speaking of this horse, leads us to observe how beautifully Providence turns even the infirmities of His creatures to good account. To look at this animal no sportsman could doubt the appropriateness of its form for hunting purposes. It was the hunter all over, with one of the lightest, best set on heads we ever saw. Added to a commanding figure, it had the finest freest action imaginable, and though the circumstance of such a horse coming to the hammer single-handed as it were-that is to say not in a stud - certainly was suspicious, still there were always fine venturesome men in the yard ready to speculate on such a piece of perfection, and it was sold in different parts of London - at Tattersall's, Aldridge's, the Horse Bazaar, and Barbican a dozen times at least before it was regularly blown. We recognised it in five hunts one season-the Royal buckhounds, Mr. de Burgh's staghounds, the Hatfield, the Surrey, the old Berkeley, and more than once saw its sleight-ofhand trick of chucking a fore-shoe half-way up in the owner's face, before we suspected what screw was loose. On each change of hunt we need hardly say it was in the hands of a different owner, and as luck would have it, about the twelfth time of "asking," our friend Blatherington Brown, the Manchester warehouseman of Friday-street, who thinks he knows more about horses than muslins, had strayed into Tat's with a nice clean fifty pound note in his blue 
satin note-case, and seeing this superb animal trotting to and fro, and Tat labouring up the ladder of bidders-a very unusual thing for Tat to do, by the way-Brown thought it wasn't possible he could take any harm even if he got the horse, and if he didn't, why giving a "bid" was a cheap piece of flash that would tell in the City. Shock Jem, the enterprising Mr. Pywell, and other cheap Johns of the yard, had run the horse up to their utmost limits, and still he stood below what Blatherington Brown had in his note-case. Accordingly he blurted out "fifty/" on the top of forty-seren, and turned on his heel with a neglige sort of air, as much as to say, he's worth that if he's worth anything.

"Fefty! going for fefty! all you all done at fefty!" exclaimed Tattersall, with a quick glance around, and in another instant the hammer was down.

Blatherington wanted a second horse, for he was going to Brighton, where he meant to play old gooseberry with the Brighton and Brookside dogs, to say nothing of astonishing Colonel Wyndham, and the "East Sussex," and very well pleased he was with his purchase until he got him into the Sussex clay, when he began to play his old tricks, and off went the shoes. A horse is desperately soon blown in the country; we don't mean in his wind, but in his character, and Brighton being only a slice of London, poor Claudius Hunter, for so Blatherington christened him, after the great civic patron of white horses, very soon had his London reputation tacked to his Brighton one, and he was what theatrical people call $\mathrm{d}-\mathrm{d}$. In this dilemma it occurred to the fruitful mind of old Mr. Boss, the tit-tup-ing, Hessian-booted riding master, that Claudius might prove a valuable acquisition in his stud. It may appear singular to our readers that a horse which was a drug in one man's hands should be an acquisition in another's, but Boss had lived a long time in the world, almost as long as Widdicomb, who 
Punch says has turned three hundred years, and Boss had learnt a thing or two. Among other things Boss had learned that half the people who hunted from Brighton only hunted for the sake of wearing red coats, and that they were never so happy as when they got off their horses, having qualified to strut on the flags and tell their exploits to the ladies. The only difficulty of doing that is an excuse for coming home, and Boss saw that a horse that would furnish his own excuse would not only be in great request, but would also be able to go out very often. Accordingly, he threw himself in Blatherington's way as, slipper on foot, Claudius and he re-entered Brighton by luncheon time, having disposed of a shoe about Firle. Boss, of course, knew the horse's infirmity, and finding Brown in the parting mood, they very soon made a deal. Well, Claudius was the most popular horse that ever entered Brighton-like a belle at a ball, he was always engaged three or four deep. His colour was greatly in his farour, for though it is a generally received axiom that a white horse should always be forward, yet as it takes halfa-dozen fields or half-a-dozen fences to settle people properly in their places, a horse that always declined before the rubicon was reached could never be said to be conspicuously behind. Indeed Claudius always looked most promising. When other mad devils were yawning and boring, and rushing and shaking their heads, like terriers with rats in their mouths, Claudius was as cool and collected as possible, taking his fences as though he meant to go on fencing all day. But that was all deception-Claudius was an honest horse, and never disappointed his rider; as sure as he came to the sixth fence, so sure would a shoe be gone or going. Then, with well feigned regret and disgust, the rider would pull up, and after receiving the condolence of the passing field, would cast about in search of a smithy, and slipper on foot 


\section{THE BLACKSMITH}

would re-enter Brighton by the longest route, so as to display the faultless pink on the faithful white. Then young ladies sitting in bay and balcony windows, bending over novels, or laps full of work, would exclaim - "Oh, dear! there's that orrid Mr. Spoonbill coming home from hunting;" or-"Oh! I declare here's Captain Green on the white horse, looking so nice."

Then Mr. Spoonbill having lingered by the way, answering every inquiry any one would have the kindness to put to him relative to the run, would at last render up Claudius to the hands of Mr. Boss, and, repairing to his lodgings, would re-arrange his curls and whiskers, and, putting a most deceitful little macintosh over his scarlet coat, would go clonk, clonk, clonk, with his spurs on the flags the rest of the afternoon, a cross between a post-boy and a heary dragoon.

But, Lord bless us! what a way out of our ground this mention of Claudius Hunter has led us. We have been taking a canter on Brighton Downs, and a ride through the town, instead of sticking to the hero at the head of our paper. Well, here goes at him again.

Elijah Bullwaist is a full flowering specimen of the old tribe of "horse and cow leech," and for the benefit of posterity we will impale him on our sheet. Bullwaist's monstrous bulk is further increased by a profusion of foul, filthy clothes. He seems as if he carried his whole wardrobe on his back. Peering above his nasty rusty black duffle frock coat, we see as many dirty waistcoats as would serve the gravedigger in "Hamlet." Above the rusty-stained unwholesome duffle, with its broad binding, parting from its seams and sides, is one of those ancient abominations, a Witney coat, with large mother-ofpearl buttons. It was once white, but the days of its whiteness are long gone by, and it is now a sort of 
whitey brown walking pestilence, combining the odour of tobacco, aloes, sulphur, oil, turpentine, opium, what Bullwaist calls harbs (herbs), a definition that he applies to all medical ingredients that he is not particularly acquainted with. Harbs and brandy are grand specifics in Bullwaist's pharmacopœia.

Bullwaist's corduroy breeches and gaiters partake of the general nastiness of his apparel, and two great slits across the middle of each shoe give him the air of being troubled with the gout, or perhaps corns, a sort of retribution for the many his bad shoeing has entailed upon horses. A careless twisted red cotton kerchief chafes against his unshaven chin, and an old shallow-crowned, broad-leafed, napless black hat, protects his dirty bald head from the winds, and keeps the lank uncombed grey locks of the sides down upon his greasy coat collar. Altogether, Bullwaist has a most unwholesome sort of look; yet this is the sort of man that deals in drugs and potions, and is consulted about the ailments and accidents of cattle and horses; and, strange to say, many of the country people prefer these ignorant quacks, these blockheads, these horse torturers, to regularly educated men. They have heard of some wonderful cure, some extraordinary operation bordering on a miracle, performed by them, that banishes the recollection of all their bungling failures, and of all their broken promises. Some, indeed, carry the principle out with regard to themselves, and many a lout would rather be operated upon by a bone-setter than by a Liston, a Cooper, or a Brodie. It is wonderful the influence some of these quacks obtain over the minds of country people; nay, even over parties from whom better things might be expected. In a village, not fifty miles from London, carriage-fulls of people used to resort, week after week, to a man fully as ignorant and as brutal as Bullwaist; nay, we believe, more ignorant, for Bullwaist can make a sort of writing, 
whereas the individual in question was wholly ignorant of the art.

Here is a specimen of Bullwaist's spelling. We are sorry we cannot give a fac-simile of the calligraphy itself :-

i 336. -ANthew Brown to Eli. Bullwaist.

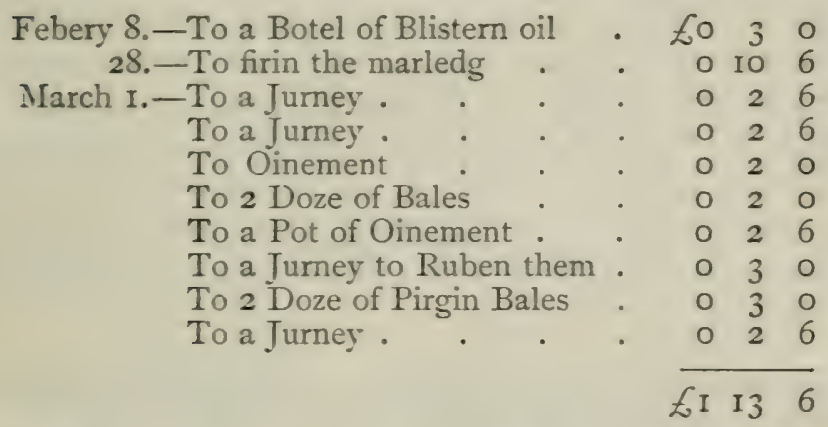

The above is really and truly an account rendered by Bullwaist so recently as is $\delta_{3} 6$, and looking at the spelling, and the style of the man, what a mass of cruelty his ignorant, brutish barbarity must have inflicted upon the poor animals that the last fifty or five-and-fifty years have brought under the ban of his ignorance. "To a Botel of Blistern oil," for a bottle of blistering oil! and to "firin the marledg," for firing the mare's leg. "The Jurney to Ruben them," perhaps requires the aid of the glossary even more than the others, and were it not for the "pot of oinement " that precedes the item, we should have been puzzled to collect that the "Jurney to Ruben them," meant a journey to rubbing them with the precious stuff.

We have another bill of the same worthy's before us, where there is a charge for "a bottel of esens," meaning a bottle of essence (essence of what? we wonder), and there is an item "To Rowling the mar and sane," or sow, we cannot tell which, that quite 
beats our power of deciphering. Then the impudence of a fellow so replete with ignorance charging as much, nay more, for his medicine than the regularly educated practitioner. Three shillings for two "pirgin bales," meaning, we presume, two physic balls, which we all know can be bought at any chemist's for a shilling a-piece, or for ten shillings a dozen. The veterinary surgeons, we may observe, do themselves no good by exorbitant charges for medicine, it only drives custom away to the chemist that would otherwise come to them. "Live and let live," is a good useful motto, applicable to vets as well as to other trades. There is a story told of a young "sawbones," who, on sending in his bill to his solitary patient, added the following note :-

"Being a young man anxious to get forward I have charged and Elijah Bullwaist is in a somewhat similar predicament, only he is an old man whose business has left him.

Twenty years ago Elijah had the sign of the Rising Sun in the centre of the village of Hatherly, with a well frequented smithey adjoining, but irregular conduct caused him at length to forfeit his license, and he has now a beer-shop and forge at the east end of the town, where he carries on a second-rate business as a blacksmith, and a first-rate one as a blackguard. This beer-shop is the resort of all the vagabonds in the country; poachers, trampers, tinkers, discarded servants, hawkers, pedlars, raffs of all sorts, who find in Bullwaist and his numerous progeny, congenial spirits and ribald company.

There, over the lowest, basest, most revolutionary prints, they charge the result of their own misconduct on the laws, and heap abuse on every one whose authority keeps them in control. It is a sad sight to see a hoary old sinner, like Bullwaist, leading his own 
children on in a course that has been productive of his own ruin. It is a sad thing for a country to see the seeds of vice ready to spread and waft in all directions: to calculate that the nuisance of old Bullwaist is to be the lot of many parts-Bullwaist is a bad man. It is one of his boasts that he never goes to church, and we never knew one who so boasted that was to be trusted.

Parents should bear this fact in mind, that there is no occupation or employment in life in which the character of themselves is not inquired into with

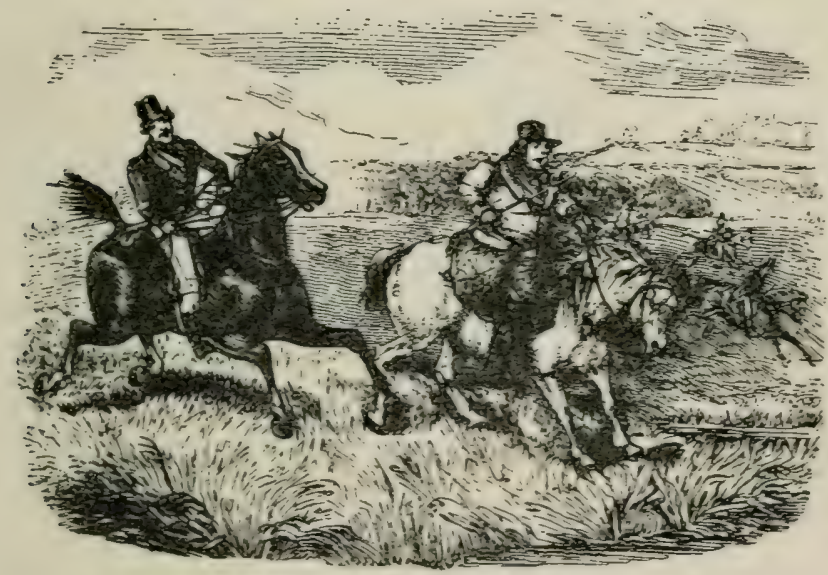

regard to their children. If the parents are honest, steady, respectable people, there will be every reason to believe that their children will be the same, at all events the world will take them on credit as such, but if parents are notorious wrongdoers, the evil of their reputation will attach to their children, and be serious impediments to their worldly advancement.

We may also add, though we have no desire unduly to stigmatize a class, that few people are fond of engaging with those who are connected with beershops. "Inn" service is generally considered bad enough, but bold must be the man who tackles with 
the offspring of the beer-shop. We never look at one of their nasty, dingy, common-looking signs, without thinking what apt prototypes they are of the squalor within. But the hounds are away, and here is old Bullwaist, as usual, getting in people's way. $\mathrm{He}$ doesn't seem to like water a bit better than his nag. "Now, old boy' l" we fancy we hear this red-coated buck exclaiming, as he dashes past, leaving old "Waist" in the lurch. 


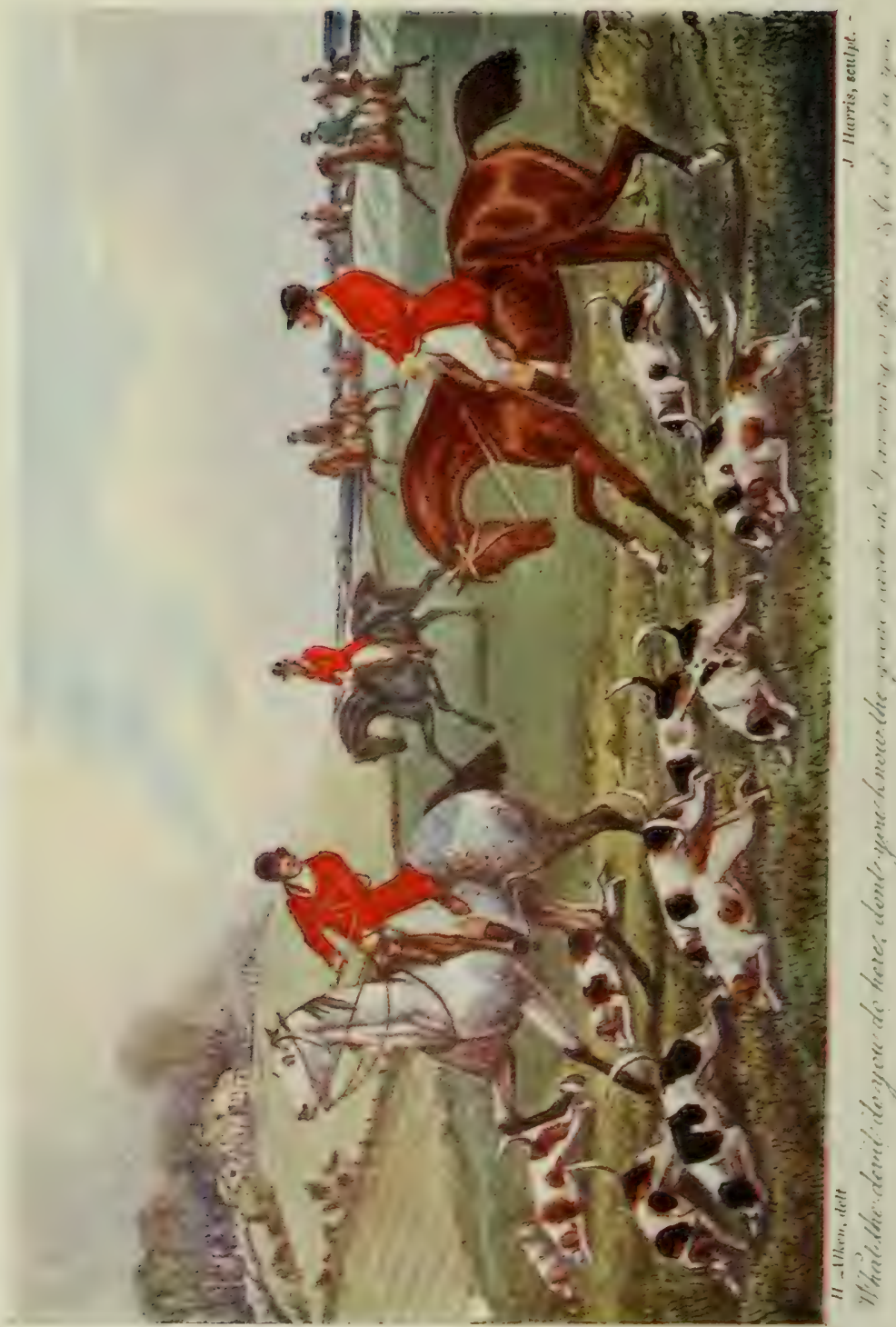


\section{CHAPTER XVI}

THE SQUIRE

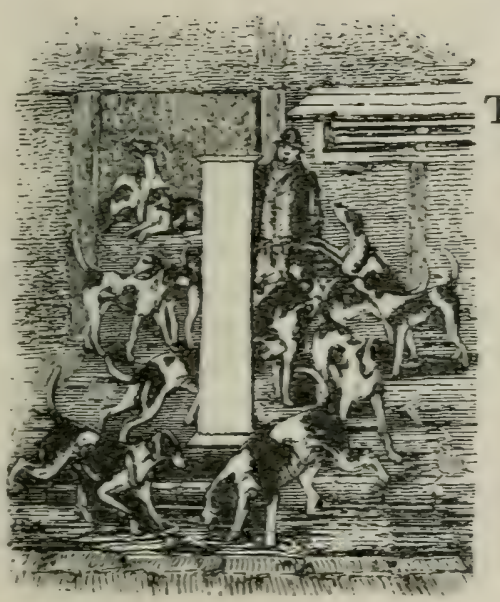

is only those who have been much abroad that can rightly appreciate the advantage of having resident country gentlemen. It is only the absence of the class in other countries that impresses us with the conviction of its importance in our own. In no other country in the world do we find individuals with

the same power and territorial possessions occupying so unassuming a place in the national scale-men that in this country rank as mere Esquires, in other lands would be princes and magnates from the importance of their possessions. We, who have seen marquises presiding at gaming tables, and counts figuring off behind counters, feel proud of belonging to a country whose greatness is based on such substantial foundations.

The title "Esquire" is so prostituted by the indiscriminate application of modern usage, that were it not founded in respectability, and maintained by its "order," it must long ere this have fallen into dis203 
repute. Every man dubs himself, or is dubbed, "Esquire." One of the judges, in reply to an objection of counsel, that a man had improperly described himself an "Esquire," observed that it had been held that every man who was not a gentleman was entitled to be called "Esquire;" and a still older authoritywe believe the lamented Mr. Thurtell, or one of his confederates-propounded the doctrine that keeping a gig and horse was proof of a man being a gentleman. In spite, however, of all its misapplications-in spite of all the jibes and jeers levelled at the class, there is still something about the title "Esquire," or "Squire," peculiarly grateful to Englishmen, and peculiarly expressive of the tranquil simplicity of country life. Strictly speaking, we believe the title of Esquire is the prerogative of parties named in her Majesty's commission of the peace, of members of certain professions and callings, but there is no doubt that its real working identity is the lord of the soil, the country resident-the country justice, if you will, but the follower of field sports, at all events. This is the sort of being that the title "Esquire" suggests to the minds of Englishmen, and this is the sort of "Squire" that the country people look up to as the highest authority within the scope of their imaginations. And rightly, we believe, they do so look up, for a well educated right thinking gentleman is an acquisition in a district, and are best appreciated, as we said before, by those who have witnessed their want or removal. We may even go further, and say, that counties well supplied with resident gentry exhibit a much smaller amount of crime than counties where they are scarce. All statesmen are aware of this, and it has always been an object with Governments to afford, by the encouragement and protection of country sports, every inducement to landowners to live on their estates.

We consider the maintenance of field sports of 
immense importance to the well-being of a country. 'They not only engender a fine manly daring spirit among all who are in any way drawn within the scope of their influence, but they materially tend to promote a healthy spirit of sociality and intercourse among neighbours. Nor are their beneficial effects confined to the mere followers of field sports; all the inhabitants of a district, all who are in any way dependent upon others for the amusement of themselves or friends are benefited by their existence and prosperity, and interested in their maintenance. To illustrate this, let us look at the case of a large country house in a sporting district, and one in a country where there is neither hunting nor shooting.

The great difference between London society and country society is this:-In London we get people together just when and for as long as we want them, at a time of day and under circumstances peculiarly adapted to the development of anything like information, talent, or humour; whereas in the country, people must be thrown more upon each other than the average stock of reminiscences and parish politics will find conversation for. Here people get into their carriages, if they have them, or street equipages if they have not, and five or ten minutes will take them to their most distant friend; but in the country, visiting is oftentimes a serious job-a matter of two or three days' business. And then comes the consideration, what are a host or hostess to do with their good friends when they have got them scraped together? Now, we take it will be readily conceded by all who have tried it, that of all dull, wearisome, up-hill work, there is nothing equal to dragging out a tedious existence among people with whom we have little in common, where breakfast, luncheon, and dinner are the only alleviations of the settled stream of inactive monotony; in other words, that mere eating and drinking are not sufficient inducements to 
draw people from home. Have we a country reader unoppressed with the mental incubus of a three days' visit to a stupid country house, where the good people, though desperately glad to see you, are high and dry for conversation before it is time to dress for the first day's dinner? Suppose it a first visit, entailing the magnificence of the "best of everything," and the usual pressing and urging of people for miles around to meet. The scene opens in the drawing-room, with the usual apologies for the smallness of the party, and the recital of a long list of invited friends who have been too shrewd to be victimised. Mr. and Mrs. Gabble were asked, and had promised to come, but unfortunately Mrs. Gabble's mother had arrived from Boulogne-sur-Mer, and would neither accompany them nor hear of their leaving her. Captain and Mrs. Smith were both laid up of bad colds, or would have been there, and Mrs. Buggins had just got her eleven boys home from school, and could not leave them, and Miss Toby and her brother had just gone on a visit to their rich uncle's; and so they go on through a long list of shuffles and apologies, ending with the usual asseveration that it is "a wretched country for neighbours-not such another bad one in England" - the common denunciation, in short, of all unlucky party pressers. The victim listens with polite complacency, inwardly chuckling, perhaps, at escaping so many bores, until his satisfaction gradually changes into astonishment at what has brought him there himself. Some men are so dense as never to remember that mammas consider it part of their duty to bring all the single men to their houses to give their daughters a chance, and think because they have no fancy for any of the girls, that the girls cannot have any design upon them. Innocent youths! There is not a man goes into a house where there are girls, without being more or less bespoke or assigned to some one or other of them. 


\section{THE SQUIRE}

But we must get on with our visit, or we shall make our sketch as long as the infliction itself. If a dinner passes heavily, what a prospect there is for the evening! What a spirit-depressing thing it is to feel that no gentle knock or quiet area ring, following the slow rumble of wheels, will bring liberation through the footman's hands, but that we are regularly booked, and in for the night--not only the night, but two following ones, with the addition of long unoccupied days. One day, however, shall serve for all. Let us suppose the dawdling breakfast at last finished, that it has been protracted even until eleven o'clock, then comes the appalling conviction of thin boots, and total indolence. The ladies retire to the drawing-room, and the wretched male victims of society, whom spurious hospitality has brought together, either follow them or make for the library. This is the time that country-house indolence is most apparent and most appalling. If a man has any, the smallest occupation or resource when at home, the first hour or so after breakfast is sure to bring it out; but in a strange house, away from his horses, his garden, his dogs, his gun, his fishing-rod, his books, his everything that makes home home, what is a man to do? There cannot perhaps be a greater nuisance for both sexes than a lot of men hanging about a drawing-room after breakfast. It must be as great a bore to the ladies as it is to the men-yet how often we see it-men lounging and idling and twaddling, until luncheon prepares them for the excursion to Prospect Hill or the ruined abbey by the river, the usual inflictions on unhappy victims. Lord bless us! we would rather break stones than be condemned to such ponderous idleness.

There is no "tip-and-go-ish-ness" in the countrynone of that light effervescence that distinguishes the active-minded man in brief contact with a sparkling circle. People in the country, though they have 
nothing to say to you, think they cannot see too much of you. They must have you alongside of them, and when at length dull time has dragged through the imprisonment, and with well feigned regrets you are about to separate, they "bind you over" to appear again on that day three months, or inform you that they are to have the pleasure of meeting you at dinner the next day at the new gaol you are going to.

Let us take the converse of this sad picture. Let us suppose a country house in a hunting country, and see the influence field sports have in procuring society. It is just like the difference between a volunteer and a pressed man. Instead of a hostess having to send out urgent solicitations to some, and embossed cards to others, the probability is that the fixture of the hounds, in the county papers, conveys the first intimation that she may prepare for a party; and instead of apologies, excuses, and backings out, the plot thickens as the time approaches.

We have heard it said that extempore speeches are always the best, and we have met people simple enough to believe well-conned orations were extempore; but that is a "fallacy" that does not require Dr. Dixon to expose. We think we shall, however, be borne out by our readers in asserting that extempore parties are generally the pleasantest, especially extempore parties of sportsmen. People may object to the conversation of foxhunters, just as they may object to the conversation of lawyers, soldiers, sailors, or any other class of men, but surely brisk, animated conversation of any sort is infinitely preferable to the forced, up-hill driblets of words proceeding from constrained people with nothing in common. Put the case in its very worst form, it leaves the unconcerned, uninterested guest the privilege of running his own thoughts and ideas through his mind, without those tiresome interruptions and appeals that invariably accompany forced attempts at "most delightful 
evenings." Eagerness and animation, however, are catching, particularly over wine, and we have seen many a jolly, laid-on-the-shelf-sportsman, and even unentered host, the one forget his years, the other his ignorance, and under the benign influence of wine and hilarity swear eternal attachment to the sport that has formed the staple of the evening's conversation.

Then contrast the early activity of the hunting morning with the sluggish inertness of the mere "house full of company," with nothing to do. Gaitered Grooms, and abortions of lads, not abortions in buttons, but abortions in boots, will be seen hurrying about getting ready for the start, while breakfast, instead of being forced as far into the morning as possible, so as to take a good cut out of the day, will be rung for at the very moment it is ordered, and woe betide the cook if it is not ready. How lively the red coats make the table look, and how each man's eye beams with pleasure as entering the breakfast-room he casts his eye on the assembled party. The very servants seem to partake of the general enthusiasm, and bustle about with unusual activity.

Suppose the meet takes place in the park, then breakfast is laid for the "million."

"Show meets," as they are called, are not generally popular with sportsmen, and perhaps deservedly not, but the ladies like them, and they tend to keep up the spirit of hunting. After all is said and done, they are harmless things; a quarter of an hour consumed in liquoring the men and parading the hounds, and another quarter in running the latter through the evergreens, under pretence of drawing for a fox, is all the mischief they do, and the man who does not like "make belieres" has nothing to do but come half an hour late.

Hunt breakfasts are capable of complimentary 
application, or otherwise, and require some tact in their management. It is clearly a compliment for a gentleman to invite a stranger into his house; it is a compliment to the man and a compliment to the sport, inasmuch as it shows that he thinks none but gentlemen partake of it. It is also a compliment to invite a general acquaintance, with whom he may not be in the habit of visiting, but whom he sees before his house; but we should almost question whether it would be a compliment to say to such a man, a day or two before, "The hounds meet at my house on Monday, and I shall be glad to see you to breakfast," because it would be almost tantamount to saying he was "just worth a breakfast, and nothing more." These, however, are points that depend upon the peculiarity of each case.

The sketch we have drawn of country visiting for mere visiting sake, and country visiting for a specific purpose, will show that hunting is not a question affecting only its followers, but one in which all the residents are more or less interested. All who like society-society in its easiest, and therefore its most agreeable footing-are interested in having a country hunted. Any"one who has seen the change produced by the introduction or withdrawal of a pack of foxhounds, will be satisfied of the truth of this observation. With a well-conducted pack, and the interchange of visiting it engenders, winter passes away almost as pleasantly as summer; and, even in the longest, hottest, brightest day, we remember with pleasure the red-curtained, sparkling fire-side comforts of the previous winter. An Englishman, indeed, is nothing without his domestic hearth. The open fields and cloudless skies of France and Italy, bring joy to the mind of the foreigner; but John Bull should be drawn in the Turkey-carpeted, fire-side party, with the little table and bright bottle of port just starting on its circular voyage. 
To the resident country gentleman having the country hunted is of vast importance; and fond of hunting as men may be, they had better put up with an inferior country and sport, than leave their homes in search of better. The man who hunts from home hunts in the most comfortable, rational, and satisfactory way, uniting pleasure and business, and not sacrificing the latter to the former.

The man who leaves his home for hunting must, to a certain extent, make a business of it, for what else can he do? Away from his ordinary pursuits and occupations, he must either hunt or lie idle, and we need not observe that hunting in other countries is about half as expensive again as hunting from home. Not only is everything to be bought and paid for at full price, but many things paid for that would be had for nothing at home-lodging, for instance-while a stud that would be ample for all the requirements of home work will be totally unequal to the demands of a regular five or six days a week hunting quarter. The resident, we think, must be very short of occupation and resources who is not satisfied with three days a week at the most.

The last quarter of a century has made a great difference in the style and habits of the country gentleman, and indeed, with the exception of a few of the old school still remaining, such a thing as a real country gentleman - that is to say, a gentleman who lives all the year round in the country-is scarcely to be met with. The last five-and-twenty years have effected a wonderful revolution in our whole social system. The means of mental resources and bodily communication have been, increased a hundred-fold. Railways and steamboats have superseded coaches, just as magazines and newspapers have annihilated books. There is quite as much improvement in the mode and economy of mental improvement as there is in the way of bodily transit. Information, 
instead of being bonded in costly quartos, and voluminous encyclopædias, irrigates the whole land in cheap tracts and treatises. A man can buy just what he wants and nothing more. So with newspapers. The son of the man who, twenty years ago, was content with his country paper, now has his London daily, and Sunday one on the "dies non."

M'Adam was thought a miracle twenty or five-andtwenty years ago, and gentlemen who had been accustomed to plough their ways to their market towns with their carriage wheels up to the axles began to think they ran easier on hard surfaces. Gradually roads became better, and the old fat maggots of horses were thought equal to two journies a week instead of one. Country houses in former days were like besieged towns, where it was necessary to keep a large stock of everything, and where everything and everybody was taken in and welcomed. Inns were then the characteristic of towns, but the improvement of roads and consequent increase of communication have established them in nearly all parts where a trade can be driven, and with their establishment the old system of taking in servants and horses has been gradually going out. Some object to the discontinuance of the custom, as contrary to the principles of old English hospitality, but like all antiquated customs it is as well to get rid of it where no present advantage is derived, and when the circumstances that gave rise to the custom have disappeared. If society is looked upon as the medium of conversation and the interchange of sentiments and opinions, then it cannot be said that servants or horses contribute to the purpose; and though it might be a breach of hospitality to send a friend's horses away to bad stabling, it would look rather like "sponging" to send them to private stables when there is good standing in the neighbourhood. Of course all this must be received with 
due allowance for time and peculiarity of situation, also for the operation of the reciprocity system. It is a very different thing taking a friend's horse in over night, and a string of horses coming for a month. In the one case the accommodation is great to the sender, and the expense is nothing to the receiver; added to which, if a sportsman, he will have a billet for his horse on the other side of the country, but it would be an awful tax upon the owner of a house in a good hunting country if he was expected to take in the studs of all the friends that the fame of the country might draw within its limits.

A place in a country Squire's house is generally looked upon by servants as the best situation. In them there is that proper personal inspection by the heads of the establishment that no really honest servant will ever object to, while there is none of that currying favour with upper servants incident to the steward's room of great houses. Our papers on "The Groom " drew from a subscriber in Paris, who states himself to be an "Old Stableman," a letter approving of our "hints," but wishing we had given the masters a few as well as the men, and among others he drew our attention to the fact that a "talking servant" will frequently command a place to the exclusion of the quiet, hard-working man. He certainly admits that the persons who hire such are "simpletons," but the tongue is such a deceitful, seductive instrument, that we fear what he says is too true, especially with young men of large fortune. Much as we are all disposed to repudiate the idea of a talking servant, often as the impolicy of trusting to them is exposed, still there is a something about the plausible subtlety of the tongue that beguiles us when the rule comes to direct application. So with persons dealing largely in promises and professions: as a general rule, we know they are always to be suspected, yet when the professions come to be made to ourselves, we are 
too apt to suppose we are the exceptions, though we should have laughed at anybody else for doing so.

It has long been a settled opinion of ours, that high wages do not necessarily procure good servants, and our Parisian correspondent fully confirms the truth of that position. Great people, of course, must have servants; but because my Lord Duke hires a Groom from Squire Rattlecover, at double the wages the Squire gave, does it follow that the man, therefore, becomes doubly good? Certainly not; on the contrary, the chances are that he deteriorates. The Squire was fond of his stable, he knew all about it just as well as his Groom; his Groom knew this, and was glad that his master took an interest in his department; the Squire knew what a man should do, and knowing it, required to have it done, but he was never unreasonable in his demands, and always considerate in his indulgences, and a community of interest was established between them, and the badge of servitude was almost obliterated by the constant contact with a liberal, right-thinking master. The man was comfortable with Squire Rattlecover, and though his wages might not be higher than the common wages of the country, still that word "comfort" comprised an infinity of attractions.

Let us glance at the same man in a nobleman's establishment. His lordship, we will readily concede, possesses every amiable quality that the country Squire does, but his intercourse with his servants is necessarily small, and the man finds himself under the dominion of other servants, instead of under the gentle sway of his former master. As our correspondent says, "he has now got to a fresh school, and his business will be to find out which is the most plausible and cunning among the upper servants, so as to acquire the greatest influence at head quarters, and then study to please and serve those upper 
servants-drive out the lady's-maid, lend the butler and valet horses, convey them or their friends to the railway-station, pick out their confidantes among the lower servants to praise them to "-in fact, make those upper servants masters, and trust to them for keeping right with the real employer. "It is no matter how good a stableman a man may be," he says, "unless he stands well with the people in the steward's room, for there is the real dominion. There is none of this," he adds, "in the house of the well-regulated country Squire, where every servant stands on his own merit, and the master and mistress can see who do their duty, without trusting to what other servants say or think."

Our correspondent, as we said before, being in Paris, concludes his sensible letter with the following observations on the difference between English and French servants. "I was surprised," he writes, "to find so many English stablemen here, some very bad, some good. The English one is always preferred, because, in the first place, he is brought from a good practical school; and, secondly, if he is of the right sort, he will be working whether his master is looking at him or not, whereas 'monsieur' always wants his employer to see how busy he is." That is a very capital description of a workman and a "make believe," and one that will apply to a great many English as well as French Grooms. We have seen fellows who did not know how to be hurrying and bustling enough when their masters were by, and yet who could employ themselves for a whole morning in jingling a curb chain or scouring a stirrup iron, when there was no one looking on. The great mischief of great houses, as we said before, is keeping more servants that can by any possibility be worked. This is what people call keeping up their station; and though we are far from wishing to see great people degenerate into little ones, we should be very sorry 
to accept a servant from many of them, even though they would pay him his wages.

But to the hunting field.

Modern custom has caused an amazing consumption of scarlet cloth in the hunting field. We are old enough to remember the time when the scarlet coat was looked upon quite as the distinguishing mark of the man of independent means, just as the gold epaulette is still looked upon as the badge of the military or naval professions. Few men in trade or business thought of riding in scarlet, except the merchant princes of London, perhaps, in the palmy days of the old Berkeley. In the country, where things are on a much smaller scale, and people more narrowly watched, it was rarely seen. Much as we desire to uphold hunting, and anxious as we are to draw all real sportsmen within the scope of its enjoyments, we confess we are not advocates for indiscriminate scarlet-coating. It imposes on no one, but draws forth ill-natured remarks from many. The man who puts on a scarlet coat advertises to the world that he is going a hunting-nay more, he advertises that he goes so often that it is necessary to have a coat expressly for the purpose. Then come the usual amiable observations that it would be better if he was looking after his business, wondering who attends to things when he is away, and so on. Now the man who goes out in a black coat may be going anywhere, especially if he carries his whipthong in his pocket; at all events he carries no convicting evidence on his back that he is going to hunt.

People instead of saying to him, "Well, you are going a hunting, are you ?" in a tone that as much as says, "What business have you in a red coat," merely inquire "If he is going to see the hounds?" and it rests with him to admit he is, or say, like Peter Pigskin, that he is going to buy barley for malting, or any other article that comes into his head. 
In addition to these arguments against indiscriminate "scarlet coating," we may adduce another that will perhaps have more weight than the foregoing. Nothing looks better than a well-appointed, wellturned out sportsman; and nothing looks worse than a badly-turned out one. Things that would pass muster uncommonly well with a black coat, are made dreadfully conspicuous by a red one. There is nothing so offensive to the eye as an ill-cut, illcoloured, bad cloth'd red coat. The majority of the wearers of them seem to think that the coat being scarlet, is all that is necessary; hence we sometimes see the most antediluvian cuts and the most out-ofthe-way fits-coats that look as if they were sent by the Jews in Holywell-street on job for the day. Did ever sportsman, we would ask, see a foxhunter figuring on the stage without a shudder? Even Widdicomb himself, great and versatile as he is, sunk beneath the character at Astley's. Who will ever forget Punch's portrait of him bowing like a man milliner in the saw-dust circle? Fancy turning halfa-dozen Widdicombs into each hunting field, with their red baize coats, outrageous breeches and boots, and marvellously caparisoned horses. Yet we sometimes see objects that are not much behind the great equestrian master of ceremonies in misconception of the character and accoutrements. If occasional sportsmen, and men dependent on the world's favours, would take our advice, they would eschew the scarlet coat, by which means they would escape alike the smiles of their superiors and the detraction of their equals or inferiors. But here comes a licensed scarlet coat wearer-Squire Trevanion of the Priory-followed by three or four friends who have come to his house overnight for the convenience of the "meet." The Squire's " chinchilla " whiskers, as Mrs. Gore would call them, show that he is rather past the prime of life, and like men vacillating 
between two periods, he presents a few of the characteristics of the times in which he has lived. The straight cut coat has never given way to the swallow tail dress, or round duck hunter, neither have the lightish drab cords been superseded by whites or leathers. Even the horse's tail has escaped the long prevailing switch or swich, and appears in the good old fashioned square cut--Lord bless us! we are old enough to remember the time when it was the fashion not to allow horses any tail at all, or ears either scarcely. When we used to see nags as close docked as the old waggon horses, leaving them something very like a whitening brush sticking out of their hind quarters. Squire Trevanion has seen all these, and being satisfied of the folly of fashion, has adopted and stuck to the cut of his youth. A clinging to old customs is perhaps one of his characteristics. Though he travels by railways, he stoutly insists on the superiority of the chariot and posters. Squire Trevanion is, however, a right, steady going, well thinking man, and his word and opinion are taken when those of many of the "new lights" will not go down. Honest men will leave matters to his reference, rather than go to Messrs. Sharp and Quirk of the neighbouring town, and he is considered the worst friend the lawyers have, for he makes up no end of quarrels that would otherwise bring grist to their mills.

Like all men whose names end in "ion," he traces his pedigree back so far that none but a "Burke" could burrow to his original ancestor. Suffice it for us to say, that the family have lived so long at the Priory, that the country people believe they have been there ever since the world began; and as in London we have but one "Duke," so in Mr. Trevanion's neighbourhood there is but one "Squire." Not but that there are plenty of others, but he is the Squire par excellence. 
The Priory is a comfortable old-fashioned Elizabethan house, with its stables behind, the whole embosomed in lofty oaks of stupendous growth, whose spreading branches harbour myriads of rooks, that keep up a lively clamour about the place. The house is neither too large nor too small; no state rooms "put away," but everything comfortable, commodious, and neat. The estate shows the best of farming, and everything about bears the impress of care and attention.

As a sportsman, in which it is more our province

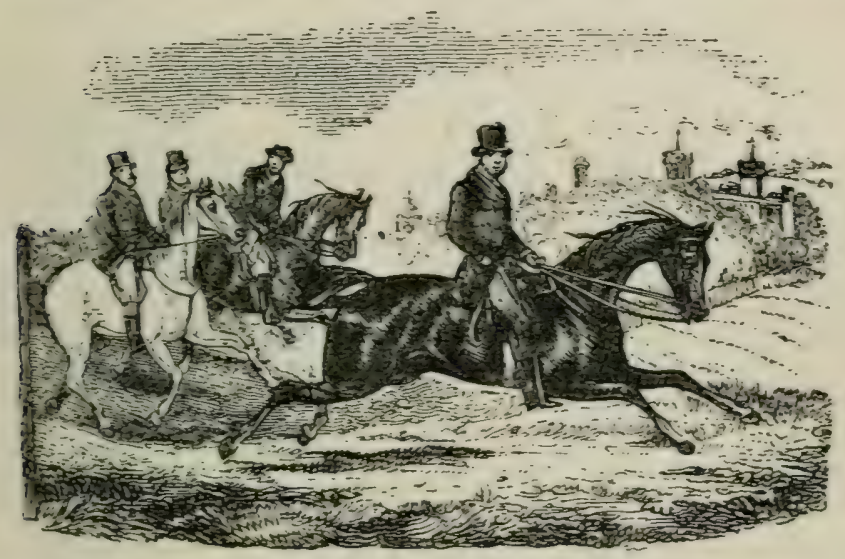

to regard him, he is one of the "never-do-mischief sort," and though a fair rider for a man past the grand climacteric, will always turn out of his line to avoid damage. Living in the country, and observing the effects of seasons and of circumstances, he knows what really is harm and what is not, and never makes unnecessary clamour about trifles; neither does he sacrifice one sport for the sake of another, or make a business of one to the neglect of the other. He has a fair show of pheasants about the house, and hares, partridges, and pheasants scattered over the estate in sufficient abundance to show ample sport to a man 


\section{THE HUNTING FIELD}

blessed with the use of his legs; but as to drawing them together for a battue, that is a thing he has never thought of. He has no desire to see his name figuring in the country papers with so many hundred head of game attached to it. Down with the battues! say we. 


\section{CHAPTER XVII}

\section{LORD EVERGREEY : WITH SOME THOLGHTS ON TUFT HUNTING}

"There is more virtue in a saddle than in the whole materia medica."-Thistle WhIPPER.

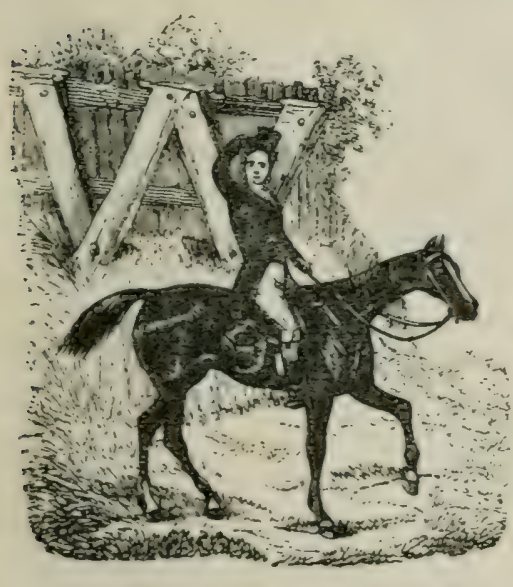

$\mathrm{HO}$ comes here? Who is the venerable, thoughtful-looking man riding quietly into the field with the rein on the neck of his well-bred bay hack? He greets Peter Pigskin with a familiar "Halloa, Mr. Pigskin, how are you? glad to see you."

Peter quickly raises

his hat as high as the hunting string will allow, with a "Good morning, my lord, glad to see you down among us again."

"Can't be more pleased than I am, Mr. Pigskin, I assure you," rejoins his lordship, his intelligent eyes sparkling with pleasure as he surveys the glad scene-

Where all around is gay, men, horses, dogs;

And in each smiling countenance appears

Fresh blooming health and universal joy." 
By the way, our friend Somerville is not quite correct in his phraseology - "dogs" is a term not allowed in speaking of hounds. However, never mind, he is a pleasant poet, and we forgive him.

The nobleman now entering the field is a minister -one of the Cabinet and Lord Lieutenant of the county. He seeks relaxation from the toils of office by a run down into his native county. Last night's mail train brought him down, to-morrow night's train takes him up. $\mathrm{He}$ is going to enjoy a stolen pleasure. Lord Evergreen has been a sportsman from his youth, and neither age, cares, nor the trammels of office can deaden the feeling within him. Deaden it, forsooth! they are more likely to cherish it-to increase it.

What so likely on a mild February morning, when mistaken birds are warbling their premature notes in St. James's or the Green Park, and sprouting shrubs are opening their silly buds - what so likely to awaken the victim of red boxes and Downing Street to the delights of the real country, as the too palpable imitation and efforts of nature in town.

We are quite certain that the parties who enjoy hunting most are those who cannot command an unlimited quantity of it. The regular five-days-aweek-man looks to the sport and the sport only; whereas those who only get it by fits and startsthose who exchange the unsporting, unnatural cerements of brick and mortar for the broad open enjoyment of unrestricted, unadulterated country-are the people that get the "sermons out of stones," and good out of everything.

Let people talk as they will of the wild tractable scenery of St. James's or the Regent's Park, the forest-like glades of Kensington Gardens, or the open breadth of Hyde Park, "still, still," as Sterne says, " it is not country," and we cannot divest ourselves of 
the idea of omnibuses, chimney-pots, and cabbage gardens in the distance.

But away from London, away from its toils, away from its cramping narrowness, its coldness, its stiff calculating formalities, how the emancipated mind bounds and revels in the luxury of unrestricted country. Now along the narrow valley, now through the woody grove, now over the swelling hill, from whose commanding height we see the shining river circling, till the landscape runs itself into nothing in the distance. The very horse seems to partake of the joy and inspiration of the rider, and treads the ground with a light, blithesome step, that as much as says, "Why don't you hunt oftener?" Diana, we often think, favours the occasional sportsman. How often we see brilliant runs on the very days we most wish them-days when strangers are out, or people have come a long way. Truly, sportsmen are a happy race, they have much to be thankful for, and little, very little, to complain of. Who has not seen "splendid runs" on days when hunting appeared to be almost out of the question? Again, we often think that men ride harder on occasional days, such as Lord Evergreen is now going to take, than they do in a regular four or five days a-week course of hunting. The extra excitement sends them along.

If it be true, as asserted by Dr. Johnson, that "the true state of every nation is the state of common life," who is so likely to be acquainted with the real wants and condition of a country as a foxhunting nobleman? He brings the experience of other climates, and the benefits of education to bear upon the absolute condition of the unexpecting, unprepared peasantry. The foxhunter is the man of all others to get accurate information, for he wanders about, without pomp or terror, and is welcomed rather than aroided by any. Take your commissioner, with his solemn look, inkey fingers or metallic-pencilled note-book ; is he so likely 
to get a frank, candid answer as the man whose whole manner and appearance disarms both fear and suspicion, nay, inspires confidence, and procures a ready answer to every question he may ask? To get at the real truth with some people, the only plan is to make them believe that you are after something else, and if Her Majesty's Government would take a few sharp, enterprising foxhunters into her public offices, keeping them a competent stud of respectable-looking horses, we will be bound to say they would get them far more sound, reliable, accurate information upon any subject of country interest, such as stock of wheat, sickly potatoes, poor-law workings, than lordlieutenants, or the solemn pompous-looking gentlemen, who sit in inn parlours, driving away truth, just as a fox or a shepherd's dog drives away a flock of sheep. Country people don't like strangers-they don't understand examination, cross-examination, re-examination, and blue-booking. They are afraid of pen, ink, and paper. But put them alongside a red coat, in a stable, under a shed, or behind a hedge, and they will tell you anything you like to ask them, simply because they think you don't care to know it.

This hint is worth the consideration of the Home Secretary, especially after the expense the late Government was put to in getting up the potato panic, and if he thinks well of it, but fears the cost, or doubts what Joe Hume may say, we should be glad to see if we could not make some arrangement so as to carry it out between us. If the Government, for instance, would find horses, we would pay expenses, or we might join, and job a few horses of Tilbury, for the first season, to see how the thing worked; all that we should stipulate for would be, that the parties should be sent into civilized countries where there is decent hunting, so that their reports of the chase, for publication, might indemnify us for our share of the expense. 
Certain we are, that there is no invention so fine for suppressing the truth as a Government commission and a fuss.

The hunting field has been said to be the great leveller of rank, but that is not the case. The hunting field, indeed, is a place where deference is voluntarily paid to station, because it is in the hunting field that station never demands it. Lord Evergreen comes in quietly on his hack, unattended by servants or state, and as long as the business of the day is confined to plain straightforward sailing, every one gives way to his Lordship; but when the fox is found, and goes right away, then the order of things is reversed, and those who ride behind are extremely welcome to ride in front.

It is this sort of yielding and taking of precedence that has raised the idea of foxhunting being a levelling amusement, but no one acquainted with it can entertain such an idea-at least if he does he's a fool.

What can be a finer sight than to see the Duke of Wellington enter the hunting field! Not one of those gorgeous spectacles, it is true, such as a coronation, a review, the Lord MLayor's show, or a procession to the Houses of Parliament-not one of those pompous continental exhibitions called a chasse, where armed menials keep back the crowd, and brass bands proclaim alike the find and finish; but what can be a finer sight-a sight more genial to the mind of a Briton-than the mighty Wellington entering the hunting field with a single attendant, making no more fuss than a country Squire? Yet many have seen the sight, and many, we trust, may yet see it. The Duke takes the country sport like a country gentleman-no man less the great man than this greatest of all great men-affable to all, his presence adds joy and lustre to the scene.

The Duke is a true sportsman, and has long been a supporter of the Vine and Sir John Cope's hounds. 
He kept hounds himself during the Peninsular War, and divers good stories are related of them and their huntsman (Tom Crane), whose enthusiasm used sometimes to carry him in the enemy's country, a fact that he used to be reminded of by a few bullets whizzing about his ears.

What a number of noblemen we have seen keeping hounds or acting as Masters of Hounds. The Dukes of Richmond, Rutland, Buccleugh, Beaufort, Bedford, and Cleveland; the Marquises of Salisbury, Londonderry, Hastings, and Tavistock; Earls of Derby, Harewood, Ducie, Chesterfield, Scarborough, Lonsdale, Fitzwilliam, Fitzhardinge, Radnor ; Lords Anson, Middleton, Southampton, Forester, Petre, Yarborough, Hawke, Elcho, Portman, Gifford, Althorpe, Hastings, Glasgow, Kintore, John Scott, Bentinck, Redesdale, Suffield, Parker, Galway, and others, whose names do not occur to us at this moment.

Many of the above hunted to great ages, and lived all their lives in enjoyment of excellent health, from the invigorating pursuits of the chase. Lord Lonsdale, we believe, rode till he was near eighty, the late Duke of Cleveland hunted his own hounds till he was well up to seventy, and the late Lord Harewood may almost be said to have died in the saddle, somewhat turned of that age. Lord Evergreen might pass for fifty, though he has not much change to take out of sixty.

But let us take a glance at the "order" generally. Though the style and magnificence of our nobility is very imposing in London, still it is in the country that they should be seen to appreciate their true influence and importance. In London there are too many of them; they are too closely packed, to say nothing of being over-ridden by the dazzle of the Court, for them to shine singly in their individual lustre. In the country they rule despotic. They are the great stars of their respective hemispheres. Great- 
ness stretches itself out, and grandeur has room to shake and show itself. Indeed, we believe there is more uniform state-more constant show in the country than in London, where recent years have confined the state equipages and liveries to levee and drawing-room days. Greatness has been cropped a good deal, too, by the introduction of railways. Coach and four succeeding coach and four, and saddle and carriage horses, accompanying servants' van, all tended to keep up the character and importance of the English nobleman. Now they are put on a truck and tacked to the tail of a train, with little more ceremony than attends the transit of $\mathrm{Mr}$. Flatcatcher's race-horse, or Mr. Bullocksmithy's fat ox. The utilitarians will tell you that it is all the better, but we don't know that it is for all that. Some one said "there had been ten men hung for every inch they had curtailed in the judge's wig," and state-even on the road-was not without its advantages. To be sure the public style of travelling favours intercourse with the world and knowledge of life; but, as we said before, there is no better place than the hunting field for acquiring that. However, railroads are now the universal mode of travelling, and my Lord Duke and family, who formerly made a grand progress though England of many daystravelling with a retinue as long as Polito's or Wombwell's menageries-now whisk from one end of the kingdom to the other in the liberal limits of a summer's day.

Let us look at a nobleman "at home," as Mathews used to say of himself.

What a world in miniature a nobleman's castle is. Placed in nature's choicest, sunniest spot, it looks upon all the luxuries, necessaries, and enjoyments of life; waving corn-fields rise beyond the parkherds of deer are scattered over it - the many-coloured and scarcely less picturesque little wild Scotch kyloes 
fatten in droves, while the more sedate and matronly cows graze indolently in groups-hares, pheasants, and partridges run and bask about, with a sort of privileged security-the rabbit warren is alive, and the sedgey sun-bright lakes swarm with fish and wild fowl, and the clear purling stream with beautiful speckled trout. In those paddocks may be seen brood mares and foals, the winners, and expected winners, of our great prizes, while in others the wornout favourites of the hunting field close

\section{"A youth of labour with an age of ease."}

Then the stables, the coach-houses, the harnessrooms, the straw-houses, the granaries, with all their concomitants of grooms, coachmen, postilions, helpers, and the out-lying kennels - out-lying, but not too distant for the mellowed notes of the baying pack to fall with the sweet west wind on the listener's ear as he stands at the castle gates. There is nothing sets off, nothing enlivens a place like a pack of hounds. Even in summer they are an object of attraction. How beautiful they look in a morning, passing indolently at exercise among the venerable trees and glades of the park, attended by the hatted and purplecoated servants of the hunt, wearing at once the stains and laurels of the bygone year. Even if a great man does not hunt, still a pack of hounds is an ornament and attraction to his place. There is nothing so popular as keeping a pack of hounds. We must all remember the noble example of the Oxford sweep, who recorded his rote for a particular candidate, because, said he, "I unts with the duke."

That duke, however, we may add, was the Duke of Beaufort, an out-and-out sportsman, one of the most popular men of the day. We have been cudgelling our brains and labouring at an imaginary description of a nobleman's establishment, whereas, if we had cast our eyes westward, we should have had 
it all cut and dried to our hands at Badminton. Take a lawn meet there. What could give a foreigner a finer idea of the vast magnificence of an English nobleman's establishment than what he would see at that fine old place. The splendid hounds, the magnificent horses, the countless servants, the bountiful hospitality within and without ; above all, the openhearted, unaffected cordiality of the noble owner. Still hound-keeping for sheer political purposes would not answer. It is only when the owner is a sportsman, that "the fellow-feeling makes us wondrous kind," principle tells upon his companions in chase. Keeping hounds, in the hopes of influencing votes, would be a poor speculation. It would be attempting bribery upon men who are not open to corruption. Your small voters don't "unt;" nothing under a master sweep. Indeed, it is no small recommendation to the chase, that it is so little capable of perversion to other than legitimate purposes.

A nobleman's influence, however, must always be great in his own locality. There is the influence of wealth and station, almost always blended with the influence of private worth. Common people may not be great judges of etiquette or accomplishments, but they are all judges of the homely qualities of which they themselves partake. A bad husband, a harsh master, an unpunctual payer, are qualities that adapt themselves to all stations of life; indeed, we believe the lower we look in society, the more great people are respected for what they are than for what they have. The influence of intercourse is also considerable. The nobleman occupies much the same place in the country that royalty occupies in London. People all like to be asked to the Palace. An occasional dinner keeps all things straight in the country-Venison's very convincing.

And here let us take a glance at a most popular sport that somehow or other has never been treated 
with the respect it deserves-we allude to the noble sport of Tuft Hunting. True, Lord William Lennox launched a novel under that title; but as we prefer letting other people read our thoughts and ideas to reading the thoughts and ideas of other people, without meaning the slightest disrespect to his lordship, we can candidly say we have never read his work; therefore we trust, whatever may be the similarity of ideas, that we shall not be accused of "cribbing" from him.

Tuft Hunting is a fine, delicate, scientific, enterprising, subtle amusement. If the proper "study of mankind is man," surely the pursuit of a lord must be proper beyond all contradiction.

We have looked into Bailey, Richardson, and several of the old dictionaries, to see if they throw any light on the origin of the term, but we have drawn them all blank. Bailey gives "Tuft" (touffe F) a lock of hair, or bunch of ribbons, \&c., also the crest of a bird, and then "Tuft (with botanists), a thicket of trees, bunch of grass," \&c.; while Richardson deals much in the same sort of description, giving "Tuft-the top, or summit," leading one to suppose that one might say, "the tuft of the morning," instead of the "top of the morning to you," a species of phraseology we never heard indulged in. In the long tail of quotations with which this worthy gentleman obscures the meaning of words, there is one allusion to hunting, certainly, but not with the pack we allude to. The quotation is as follows:-

"With his hounds

The labouring hunter tufts the thick unbarbed grounds, Where harbour'd is the hart."

That is not our pack-ours are the two-legged hounds - the talking, babbling, fawning, courting, humbugging, glozing things called men. After all is said and done, we are inclined to adopt the hypothesis (to make use 
of a fine word) of a friend, and attribute the term to the gold tassels or tufts worn by noblemen at our universities, which distinguish them from the common herd, just as a fox's brush distinguishes it from a hare. Indeed there can be no doubt that that is the origin of the term, and we will thank the next dictionary maker to add "Tuft Hunter" to the T's, and describe them as "a breed of men whose offence is rank," or a breed of men desperately smitten with title. Rank at school doesn't go for much-at least not at our great schools where lords abound, and a marquis may be fag to a milliner's son, but at college rank dawns forth like a meteor, and subsequent adulation atones for early familiarity and humiliations. Then the fine nose of the Tuft Hunter begins to show itself, and men lay the foundation of characters that generally remain with them to the end of lifedesperate Tuft Hunters.

Like hounds, Tuft Hunters may be divided into different classes-varying like hounds in their keenness, energy, and determination. There is the bold, open-mouthed, dashing, foxhound Tuft Hunter, who runs at a lord as if he would eat him-who persecutes him-who lards him with "lordships," and does not know how to be subservient and obsequious enough. There is the pottering, dribbling, babbling harehunting Tuft Hunter, who deals more with lords in conversation than in reality, and there is the lurching Tuft Hunter, who professing contempt for the game, never misses an opportunity of having a run at it -with several minor varieties not important to our purpose.

We might carry our kennel simile further, and divide the followers into sexes. Women are generally desperate Tuft Hunters. There is no denying that. Many a poor man has been made to stoop to the scent who has no natural inclination that way. Tuft Hunting is an instinct that pervades nearly the whole 
sex. We have heard a tenth-rate milliner knock the peerage about with her tongue, just as an expert billiard player knocks the balls about on the table. Nay, there is our second cousin, old Miss Deborah Crustyface, of Canonbury-square, Islington, in whose presence it is absolutely dangerous to mention the name of a nobleman, for she immediately strikes a scent, and heads up and sterns down, runs into them even up the third and fourth generation, not unfrequently diverging into collateral alliances and marriages with commoners. Not only has she Burke, Lodge, and Debrett, peerage, baronetage, and all at her fingers' ends, but Dodd's dignities, privileges and precedence, with lists of great public functionaries from the revolution down to the present time. To hear her talk you would fancy she was the "lady," as they now call "wives" of a Lord Chamberlain, so accurately has she the ladder of consequence, called precedence, arranged in her head. She knows what ring of the ladder the Lord Privy Seal holds, as also the legitimate consequence of a knight banneret, and the place of the eldest son of a knight grand cross of St. Michael and St. George. In fact the old fool is peerage mad, though how she came to be "bit" nobody knows; for though in her occasional west-end rambles she sees people riding in coroneted coaches who she takes to be lords, she has never yet accomplished an identity so as to be able to say that is the Duke of $\mathrm{A}-$ or that the Marquis of $\mathrm{B}-$. True, that in her ruminating mind, with the aid of her books, assisted sometimes by Madame Tussaud's exhibition, she shadows forth certain ideal personages for her titles, nay, sometimes assigns the creations of her mind to corporeal objects; but she is generally as wide of the mark as the celebrated would-be Countess Ferrers ${ }^{1}$ was in her descriptions of the noble-

${ }^{1}$ The most extraordinary action of modern, or perhaps any times, was one brought by a Miss Smith, a girl of twenty, 
men and great people with whom her intended liege lord associated. We remember being victimized by our venerable relative down St. James's-street, one afternoon, when she insisted that a certain duke was Sir Francis Burdett, merely because he wore topboots; and Madame Tussaud's Sir Francis wears them also; while every big, burley, bushy-wigged man she christened Daniel O'Connell. We met six Daniel O'Connells between Sam's corner and Slaughter's coffee-house in St. Martin's-lane. O'Connell, we may tell him, may take it as a compliment, for we never knew our cousin, Miss Crustyface, descend to a commoner before. It was all owing to his generous breadth of shoulder and the fine dark cauliflower wig he sports in Madame Tussaud's exhibition, or rather perhaps all owing to his being in Madame Tussaud's exhibition, that Miss Crustyface gave herself any trouble about him.

Talking of the Countess Ferrers-or, alas! for true enterprising talent! Miss Smith — talking of Miss Smith-what a loss was there for want of a little real London information and experience. We will be bound to say, if Miss Smith had had but a tithe of the opportunities our cousin, Miss Crustyface, enjoys, she would have triumphed over the earl-at all events have made costs-heavy, vindictive costs, compensate for the loss of the coronet. Inspired young lady! If the unblushing "white rose" of the country-if the untrained, untutored mind of rural life could depict scenes and situations that outwitted her Majesty's great "cute" Solicitor-General, what might we not have hoped from the resources of an ampler field? It was not her fault that Lord Clive was painted the

against Lord Ferrers, for an alledged breach of promise of marriage; which she sought to establish by a series of letters, supposed to have been written by herself to herself. After the trial had lasted four days, the Solicitor-General submitted to a non-suit.-See PICKERING's REPORT, in I vol. 
very reverse of what he is. It was not her fault that gentlemen were stationed at Brighton who were quartered in Scotland, or that Lord Brougham was made to dine with those with whom he was not acquainted-it was the fault of circumstances-the want of opportunity of knowing better. But, take it for all and all, the performance was a wonderful-a miraculous one.

Talk of our novelists-our Bulwers, our Blessingtons, our Dickenses, our Jameses, our Hooks, or our Hoods-how they sink into nothingness, how they must hide their diminished heads before the maiden efforts of that unadulterated, unsophisticated country girl. Their writings are the produce of active and experienced lives, their ministerings are to minds predisposed to fiction (which yet they sometimes fail to move), but here was pure, innocent inexperience, storming the great citadel of reason, of Plutus, and of power, capturing legal acuteness, and all but carrying judge and jury in her train. Such efforts were worthy of a better end.

"Facts are stronger than fiction," says the proverb, and assuredly the would-be-countess has proved them so ; yet, let her not regret the loss of that "bauble," the coronet, as Oliver Cromwell called the "mace." It would but have consigned her to a life of inglorious ease, perhaps roluptuous indolence, whereas she has that within her which surpasses rank and wealththe power of leading the zerorld. If the great man of Great Marlborough Street, or some of the enterprising brethren of the press, have not a nine-volume novel coming out from her pen, all we can say is, that fiction must be out of fashion, or real talent unappreciated.

But to return to Tuft Hunting.

A real, determined, out-and-out Tuft Hunter, is a thing that loves a title merely because it is a title, without reference to fame, talent, acquirements, 
agreeableness, or any of the hundred-and-one qualities that constitute the difference between one man and another. Show such a man a lord, and he "ats him" as a greyhound would a hare. The peerage occupies the sort of place in his head that ale and beer measure occupies in the head of a publican-gallons, half-gallons, quarts, pints, gills, \&c. \&c. He looks at a duke as a gallon, an earl as a quart, a viscount as a pint, and a baron as a gill, and considers that each rank holds just its own particular quantity, and that the only difference among noblemen is in the sign of the measure. In countries where game is abundant, a hound of this sort may be seen changing from title to title, always, however, on the ascendant; just as some hounds will change from hare to martin cat, and from roe deer to fox. We have known a real out-and-out Tuft Hunter inconvenience himself by taking up his quarters at hotels frequented by noblemen, even though he had not the slightest chance of a contact, except on the staircase or in the passage. Still he could talk about, "Ah-yes-ah-I remember we were staying together at the Bedford, at Brighton;" or, "Ah-yes-ah-I remember meeting him at the Plough, at Cheltenham." These are the sort of Tuft Hunters that acute keepers-alias stewards of public dinners-bait their traps with royal dukes and great men to catch, well knowing that their presence will effect what no charitable motive would accomplish. His Serene Highness the Grand Duke of DoodLeton in the chair, acts like a sugar saucer upon flies, draws all the Tuft Hunters from their holes, to flutter and bask in the sunshine of royalty. Then, if his Serene Highness takes a sham glass of wine with them, they reckon they have established his acquaintance, if not his friendship, for life. Harmless foible! So let it pass.

The most contemptible species of Tuft Hunter undoubtedly is the assiduous, cringing, never-miss-a- 
chance Tuft Hunter, who yet pretends to great independence, nay, almost blunt rudeness, to noblemen, when away.

We have met Tuft Hounds of this descriptionmen who talk as if they always spoke their minds most freely-nay, influenced the conduct of noblemen, but who yet were the most abject, servile, sneaking, fawning sycophants in "the presence," the carpet ever saw. These are, undoubtedly, the skirting, babbling, lurching things of the pack, from which no scientific master of "tuft hounds" would even breed. Tuft Hunting, however, is not a sport to be pursued in packs-indeed tuft hounds are generally so desperately jealous that it is scarcely possible to get two to run together. Tuft Hunters never agree. They are always jealous of each other being on the scent, and then as the pot called the kettle "black bottom," so the cut one calls the other "Tuft Hunter." Flashing with titles, calling noblemen by their names, or by their titles without their names, as, "Well, duke, how are you?" or abbreviating their names, is all bad taste, and has always the contrary effect to what is intended, making the auditors set the flashers down as fools, if not something worse, instead of as very "fine fellows," and "deuced thick with my lord." Flashing behind their backs is more common, but equally snobbish. Why not render unto lords the things that are lords'? There is no doubt that Tuft Hunting is an hereditary instinct, descending from father to son, and traceable through families, just like the gout, the tic, or a taste for foxhunting. A good Tuft Hunting father generally begets a good toadying son. Still we should observe that as the slightest twinge of the gout is enough to make people set a man down as gouty, so the slightest contact with a nobleman is apt to saddle a man with the charge of Tuft Hunting. It is of all imputations the easiest made, and is oftentimes made without the slightest 
foundation. Now, for our own parts, we have no objection to bear the imputation of Tuft Hunting, in as far as admitting that the society of noblemen is oftentimes preferable to the society of commoners, and we are really hardened enough not to be ashamed of the admission. If education, knowledge, talent, manners, intercourse with the polished world, are recommendations for a companion, where are we so likely to find them as in the leisure circles of the aristocracy? To run after a man merely because he is a lord, is an amusement fit only for a lacquey, but

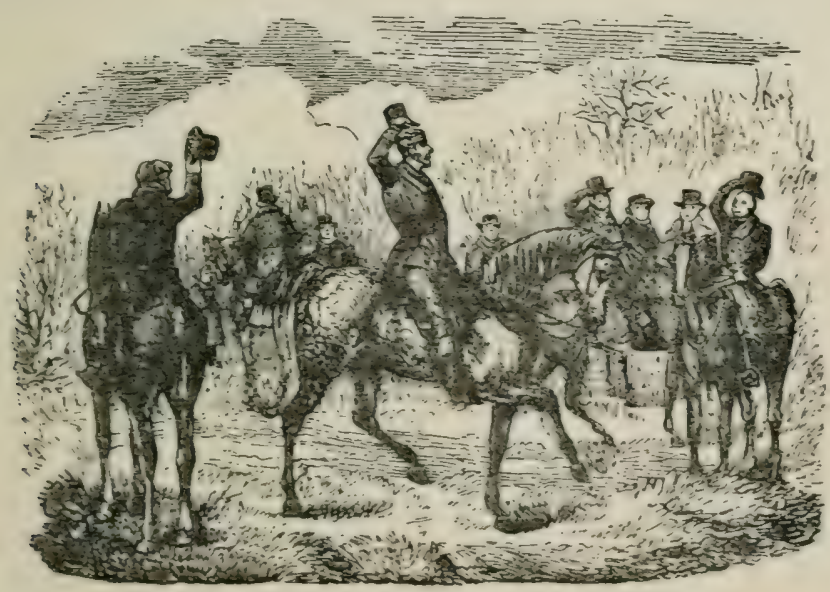

to shun a man because he is a lord, and because his acquaintance might entail upon one the charge of 'Tuft Hunting, is sacrificing rather too much at the shrine of our estimable friend "public opinion," or the opinion of the gentleman who rejoices in the title of "they say."

The fable of the old man, the boy, and the ass, is an admirable illustration of the opinion of our good friend the world, with regard to companions. If a man listens to all that is said respecting the objects of his choice, he would very soon be left alone in his 
glory. Tuft Hunting, however, is alway's more offensive than what is called keeping "low company," because, in the first place, some people have a secret pleasure in seeing others do wrong, while the protegé of the nobleman is lifted, as it were, over the heads of his companions, and thus made an object both for envy and ridicule.

Let no modest, unopinionated youth, then, be deterred, from fear of incurring the old charge of Tuft Hunting, from paying proper respect to great men. It is their due. The omission of it is rudeness, and it is only by carrying it to excess-converting respect into servility - that it becomes ridiculous. 



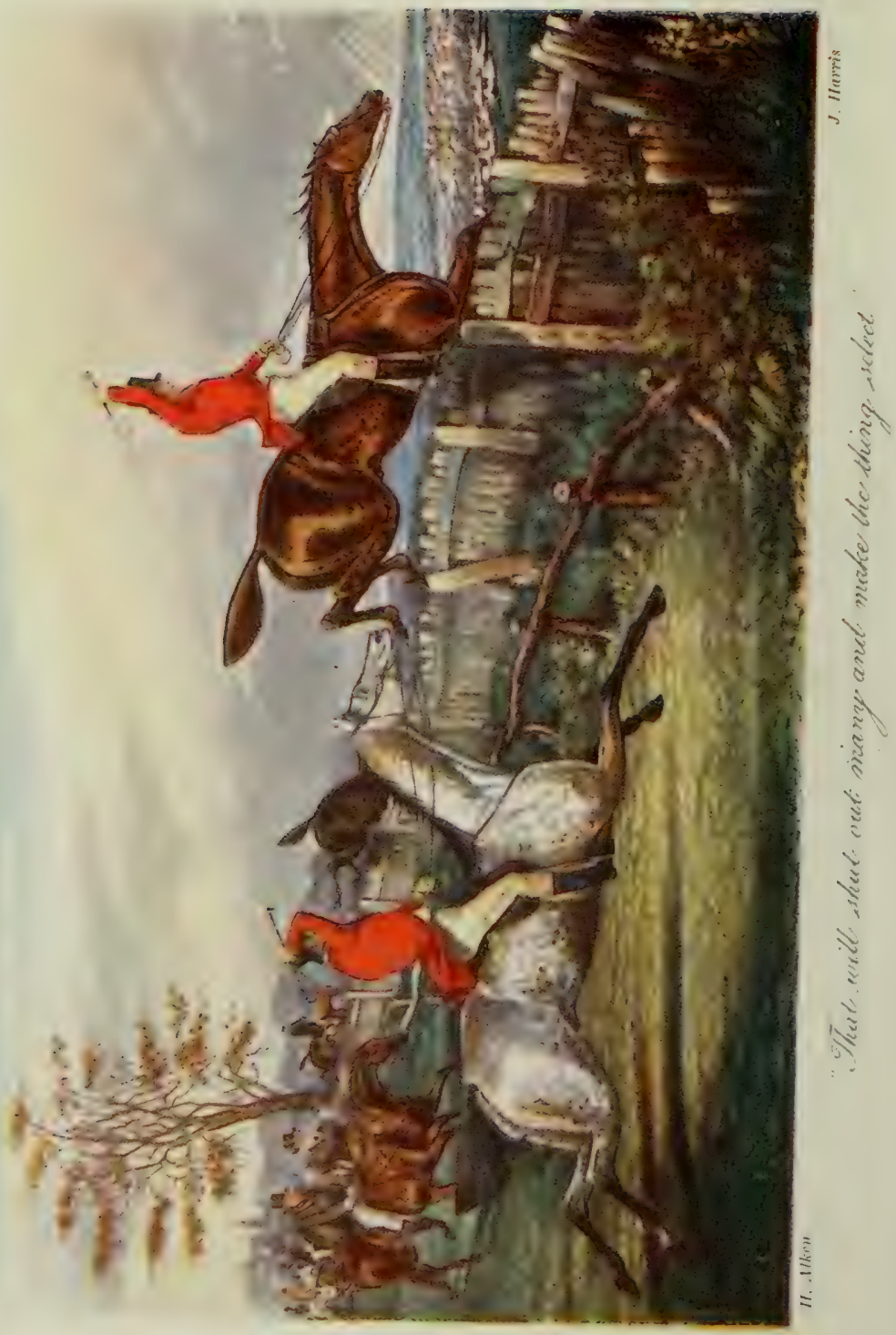




\section{CHAPTER XVIII}

CAPTAIN SHABBYHOUNDE

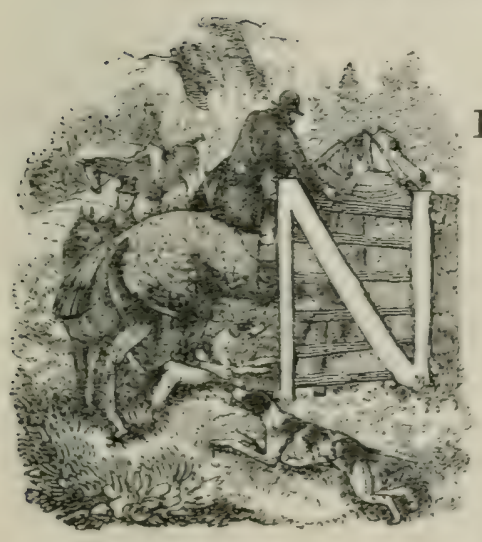

EXT to the man who is always wanting to bet with you, the man who is always wanting to sell you a horse is the most disagreeable. Most of our readers, we doubt not, have some squarey, slangy, "I'll-lay-you-twoto-one-of-that" sort of person, among their acquaintance, and many, doubtless, are oppressed with an-"I'll sell you a horse," friend, while some will recognise in Captain Shabbyhounde a genius combining both these amiable, characteristic, and enterprising qualities.

Both the above figures of speech are sometimes taken up by young men at the outset of life, more because they think it sounds fine than from any real inclination to "do" any one, as it is called, either in betting or in horse dealing. It is a mistaken notion, and one that we dare say only requires the exposing hand of our Analysis to correct. Slang and cant have fortunately taken their departure from among gentlemen, and have found refuge among the legitimate denizens of the stable. The real betting man 
is a decided nuisance; it is dangerous to open one's lips in his presence, and they may be looked upon as the kites and vultures of society. IVe never see a young man with a clasped book and metallic pencil without reckoning him ruined. They always are sooner or later.

The "I'll sell you a horse," friend, is a much more innocent creature than the betting one. The "I'll sell you a horse," sometimes arises from a paucity of ideas; it is a sort of "come uppermost thought," spoken perhaps just for the sake of something to say, like the passenger who, on a voyage to India, used to address the captain every morning after the usual salutation, with "Pray, sir, what do you think of Napoleon Bonaparte?"

Again, some men indulge in it from excessive delight at the novelty of ownership. Many people wouldn't know they had a horse if they did not advertise the fact in that way. The course of life runs thus : watch, gun, top-boots, and then a horse. The possession of a horse converts the boy into a man. Instead of being whipped himself, he gets something to whip.

After aping a stage coachman, there is nothing so disgusting as seeing a young man acting the groom or horse-dealer: we mean dressing the character as well as acting it.

Doubtless there is something very pleasant and attractive in horse dealing. There is the sort of excitement peculiar to the lottery about it. We have known men who could not be trusted at a horse auction, so sure were they to come home with some "tremendous bargain." A private deal is very engaging. The greatest ignoramus-the man who would not know which side of a horse to get on at, will nevertheless go out of his way to accompany a friend to look at a horse. That interest is a good deal excited by a desire to see an animal of which he is 
likely to hear much more hereafter. It is an interest that does not attach to a horse-dealer's transactions, because "dealing" is his trade, and he is supposed to be too wary to be done.

Mr. Whipend may buy fifty horses without any one troubling his head about any of them; but let Mr. Spoonbill be seen trotting one out, and he will have the whole "town" out, as they say.

Old John Lawrence, a kind-hearted, if not a very practical writer on horses, exclaims, "Who shall counsel a man in the choice of a wife or a horse!" but if a buyer were to listen to all the hints and suggestions he will have made him, he would stand a good chance of going on foot the rest of his life. In spite of Mr. Lawrence's exclamation, good stout counsellors will never be wanting on the animal side of the question at all erents, and the ridiculous thing is, that the lower the figure, the greater the fear on the part of the purchaser. Time was, when we used to talk about a twenty pound horse, just as we did about a twenty shilling note, a guinea hat, a silk umbrella, or any other unimportant thing; but now-thanks to the march of railroads-a twenty pound horse has become an object of considerable importance. People used formerly to talk of "giving a horse away for twenty pounds," just as our friends under the Quadrant talk of giving one a piping bullfinch for an old coat; but now twenty pounds is a most difficult sum to realize. People look at a twenty pound horse as if they thought the seller had stolen it. A two hundred pounder is an easier one to sell.

Gentlemen dealing is at best but a ticklish trade, and we doubt any one being able to pursue it for any length of time, and retain the title of a "gentleman." Every woman has been said to be a separate enigma, and the same may be said of every horse, and yet to hear an ignoramus talk, you would think there was but one article answering to the name-that they 
were all alike. There are very few horses without something or other that they would be better without, and which a man is obliged to slur over by himself, or servant, if he wishes to get rid of the animal without a sacrifice. It is just this slurring over that constitutes one of the great difficulties of gentlemen dealing. You must have a servant in your confidence -you must, to a certain extent, place yourself in the power of that servant, and where is the gentleman who would like to feel himself under such domination! Of course, gentlemen must both buy and sell; it is the buying with a view of selling again to a profit that constitutes the horse-dealer. The best plan is for a man to look upon horses as an article of luxury, for which he must expect to pay something, instead of expecting a profit, and then that man is best off who pays least. It is not worth any gentleman's while, for the sake of a five, ten, or even a fifty pound note, saying anything about a horse that he knows is not borne out by the facts. We have heard men assert that anything is fair in horse dealing, but that is the mere bravado of some notorious cheat, wanting to carry off his delinquencies on a general principle. Lying is never allowed among gentlemen-above all, lying for self-interest. If any one doubts the truth of this position, let him observe the coolness, the shirking, the cutting that attends a man of this description in the hunting field. Instead of the hearty, joyous welcome that greets the legitimate sportsman, there are cold, sour looks and mutterings about cheating scamp, and wonderings who he is come to "do" now. In remote parts there is no scope for this kind of work; a false deal or two does for a man, and no one will look at his horses after; and even in London and the metropolitan hunts it is wonderful how soon a man is "blown." In our opinion, gentlemen dealing, with a view to money making, is the most unpromising of all speculations. Some men have a vanity about 
the thing, and assert they make money, even though they lose. This is a sort of vice, or folly, that carries its own correction along with it. Some again only count their "gains," leaving the long catalogue of losses to the account current, which somehow or other never comes to be balanced.

It has always appeared to us that the prejudice of the day has affixed a very illiberal and unmerited odium on the trade of a horse-dealer. Doubtless there are scamps and cheats in the business, just as there are scamps and cheats in all trades, but taking them as a whole, we believe there is more honesty among the regular dealers than there is among what are called gentlemen dealers. Let us examine the position and peculiarities of the two. The licensed dealer generally does business in a large way; for one horse that passes through the hands of the gentleman dealer he will have fifty through his, and though quick sale is the soul of trade, and it is his interest to keep passing horses through his hands, he gets far more abused for an occasional failure than the gentleman dealer, who must know all the faults and weak points of his horses from the length of time he keeps them, and the personal trials and examinations he makes of them. We consider it just as impossible for the licensed dealer-at least a licensed dealer in a fair way of business-to know all the ins and outs and peculiarities of the horses passing through his hands, as it is for the gentleman dealer to be ignorant of them. The licensed dealer must occasionally make mistakes, must occasionally be taken in himself, yet if he passes the deceptive horse on quickly to a customer, he gets blown up and abused, as if it had been a premeditated robbery.

With respectable dealers, the faulty horses are the exception, and not the general rule; but we have too much reason to think that with many of what are called "gentlemen dealers" the faulty are the rule 
and the sound ones the exception. It is ridiculous to suppose that men whose business is horse dealing - who have been at it all their lives, and many of their fathers before them-with the extensive ramifications of long-continued business - can find it their interest to deal in what must be unsatisfactory articles to their customers, or yet that such men are to be beat out of their own markets by the newly jumped up capital-less judge of yesterday. These "gentlemen dealers" as they call themselves often take up the trade, because it is a ready-money one-ready-money at least as far as the seller is concerned, though we are not quite so sure about its being a ready-money one when they are the buyers. It is then "I'll give you a bill at three months," or, "If you don't want the money at present, I don't care if I give the odd five:" whereas the regular dealer is the credit giver, if there is any. Indeed it is this credit giving that tends to run horses up to such enormous prices in London. Even of licensed horse dealers there may be said to be two distinct classes, namely, the dealers in young fresh horses, and the traffickers in aged, blemished, second-hand ones, as they may be called. It is the province of the latter that the "gentlemen dealers" chiefly invade. Again there are men calling themselves gentlemen, and even admitted into the society of those who are, who do not hesitate to act as middle-men between a buyer and a seller. We have known men who did not scruple to take a fivepound note for buying a horse "cheaper," as they call it, for another than he could for himself. These are the men who talk themselves into the reputation of judges, and the ignorant and uninformed in these matters are glad to avail themselves of their experience rather than trust to the word of a dealer. The dealers know these men, and know that unless they have their good word they have very little chance of selling their horses, and of course that good word 
must be obtained by the usual means, and, as a natural consequence also, the usual means must be added to the price of the horse, so that the purchaser by employing such a party is in reality running up his own price. The same sort of thing descends in the scale of life, and the coachman must be propitiated when a new pair of horses arrive, or they will stand a very poor chance of finding favour in his eyes, and the groom will expect a similar compliment on the arrival of a hunter or hack.

The hero whose name we have placed at the head of this paper, and who is just now entering our hunting field, is an admirable sample of the tribe we have been describing - a gentleman horse-dealer. Captain Shabbyhounde is a man who lives by his wits, and is what is generally called, "up to everything." He can ride a race, ditto a steeple-chase, play billiards, ditto rackets (which by the way he studied in Denman Lodge, as they call the Bench), buy a horse, sell a screw, measure twelve paces, cut the cards, row a match, shoot a ditto, and take the part of a walking gentleman in private theatricals.

Forty years, five-and-twenty of which have been spent in elbowing, and active intercourse with the world, have tended to polish Shabbyhounde's wits up until he is as keen as a razor. There are few things that he is not up to, or had a turn at, though if his habits have acquired any settled direction it will be for race and steeple-chase riding, billiard playing, and horse dealing. Hunting, it will be seen, we have not enumerated in the catalogue of the Captain's accomplishments, for to tell the truth, he only hunts as an auxiliary to horse dealing, and we are not desirous of enrolling such a character among its legitimate followers. The Captain's season is summer, or perhaps spring and summer, when the silk jacket and doe skins are in vogue.

Captain Shabbyhounde has a taste for horses, but 
it is not the taste of a sportsman-a taste that amounts almost to affection for an animal that pleases him; for Captain Shabbyhounde would sell anything he has-his own father if he could get anything for him-and his taste amounts to a sort of enterprising dabbling in an interesting article that brings him in money. He is a good judge of horses, and a good judge of what they can do, and has a turn for cobbling them up, and passing infirm ones off as sound. Hunting, of course, favours this sort of dealing, for as the Captain only professes to deliver them sound, if they break down on the second or third day, he shifts any blame from himself to the chapter of accidents. "Most unfortunate," he will say, "but these accidents will happen; that horse never had a moment's illness all the time he was in my stablemust have put his foot in a rabbit hole, or wrenched himself some way." If the unfortunate purchaser is a hard rider, perhaps he will throw in some "desperate leap" he saw him take, to make his misfortune lighter.

The Captain, though a light weight man, is very tenacious about not carrying anything extra. Here the racing man shows itself. Though he would not leave the "coppers" at a turnpike gate until he returns, he will nevertheless wait till the tollkeeper fumbles in all his pockets, and looks in the corners of all his drawers for one of those hide-and-seek fourpenny pieces, the most uncatchable and slip-throughthe-fingers coin. His clothes are all made on the principle of extreme lightness, and whether in cords or leathers, of which he has "two and one," he never wears drawers, and sometimes he even dispenses with stockings; his boots, too, are of the paper sort, and spurs of the true racing cut.

It would puzzle Shabbyhounde himself to make out how he came by the title of Captain. He was originally an apprentice to a clothier at Frome; but 
having a soul above "buttons," he suddenly disappeared from the scene of action, and, after regetating some time at Boulogne, returned to England a Captain, instead of, as might have been expected, a count. This was, perhaps, accorded on the strength of moustachios, a military-looking travelling cap, and a broad black stripe down a pair of blue trowsers, strapped under Wellington boots, with ringing heel-spurs. "Captain" is a convenient travelling name. Shabbyhounde had some little money at starting - a few thousand pounds sufficient to make or mar a man. A part of this he "dropped" in mastering the mysteries of the magic game of écarté, for there is little to be acquired in this world without payment, and the balance, whatever it was, has kept the Captain going ever since. Of course he has had his seasons of prosperity and depression; but he has never been seen either at the billiard or card table, or in any gambling and ready money concern, without a well-displayed purse full of sovereigns, or a stiff roll of notes, of which he seemed most thoroughly careless. Indeed, it is in scenes such as these that he chiefly shines, for it is much easier to affect the flash man than the foxhunter. Well-made clothes, smart cravats, clean gloves, good boots, are things of easy accomplishment; but it is difficult for the non-foxhunting man, at least for the man who has no real taste that way, to pass muster among sportsmen. People soon see who come out for pleasure and who for other purposes, though, as we said before, it is no small recommendation to hunting that it is so little capable of perversion to other than legitimate purposes. It may be prejudice, and because we "know the man," but we cannot help thinking there is something about Shabbyhounde's appearance indicative of his calling, and different to other people. His very clothes seem to tell his story. 
They have neither the neat appropriateness of the well got-up sportsman, nor the indifference of the careless dresser. There is a sort of attempt-a sort of shabby genteelishness about them, unknown in the general run of hunt costume.

Of course he rides in a cap. This he does for the sake of identity, and in order that none of the hazardous leaps he takes in the prosecution of his calling of horse-seller, may be appropriated by any one else.

It is not a badly-shaped cap; neither one of those ridiculous sugar-loaf things we sometimes see sticking a mile off a man's head, nor one of the squash order, that look as if they only want ears to turn down to make very comfortable travelling ones, but it has the appearance of having been made by a workman, and not of second-rate velvet either. This cap, indeed, is the best thing about him; but below it are a pair of very watchful, restless, grey eyes, full of anxiety and suspicion. "Conscience, which makes cowards of us all," keeps Shabbyhounde in a constant state of alarm. The meet of hounds, so enjoyable to the sportsman, so fruitful in anticipations, and so productive of agreeable surprises, is to him a scene of constant nervous dread and anxiety. He does not know who may cast up. The recollection of his misdeeds crowds upon his memory, and his tormenting brain conjures the figures of appearing sportsmen into the bodies of those whom his ingenuity has defrauded. He does not know how parties will receive him. He does not know whether the secret of his last "do" may have oozed out, how many of the lies he told in effecting it may have been detected, or what Groom in whose power he has placed himself may have betrayed him. All these are sad drawbacks to the pleasures of the meet - sad drawbacks to the pleasures of anything.

To the man of sensitive mind there can be no 
humiliation so great as the quiet, silent, cold shoulder reproof of a party of gentlemen.

Shabbyhounde's coat, of course, is a dress onenot only a dress one in cut, but absolutely an evening one. These dress coats for hunting inthese

"Beds by night, and chests of drawers by day,"

have always appeared to us to be the economy of extravagance, paltry in conception and contemptible in execution. If a man is such a determined outand-out sportsman that he must always have the insignia of his calling about him, surely he can afford a coat for each division of the day, and not have to look forrard to converting the superfine cloth of the drawing-room into the defier of thorns, and storms, briars and bushes, out of doors.

We are quite aware that, generally speaking, these coats are launched on the service they are meant for - that they go at once into the hunting field, but the theory is the same, they originated in a paltry idea of converting dress coats into hunting ones when they got shabby, and a shabby dog he must have been who started the idea.

Although we fully agree in the words of the old song, that there's

"Naught like boots and leather breeches,"

we do not carry our admiration for hunting accoutrements quite so high as to insist upon there being nothing like scarlet for dining in. Indeed, we don't like it. It makes too much of a business of the thing, added to which we often see the greatest cocktails in a morning the most tenacious of appearing in it in an evening.

If, however, men with their hair stiffy curled, and pumps on their feet, will put themselves into scarlet for dinners and balls, let us beg of them to get new coats occasionally. Most things look well when they 
are fresh and new; finery, above all things, should be good, for much of its popularity depends upon its newness, and scarlet evening coats are no exception to the rule. What can look nastier than a greasy annual, a keepsake, or book of beauty, for instance, or a frowsey faded piece of worsted-worked finery? Nothing but a shapeless, makeless, old-fashioned red rag dancing about. Yet what things we have seen, to be sure! and what men in them! Tall, gaunt, spectral-looking fellows, with faces the very antipodes of their coats, and little roundabout, teetotum, beerbarrel-looking things, that could never by any possibility sit on a horse. These people have coats that they got when "they hunted," as they call it, some twenty years ago perhaps, and having them, they think it right to air them every now and then, that is to say, whenever they can get an opportunity, at hunt or fancy balls, at which latter place, indeed, hunt coats are valuable, as saving many a worthy man from being choked in uniform. But if a man hopes to kill a girl-which, after all, we suppose is the real object of appearing in scarlet - let him ascertain before he commits himself, that there are no military going, else his plain coat will have a very denuded, stripped-of-its-lace appearance by the side of the glittering uniforms of his competitors. Hunt coats are best at hunt balls.

Shabbyhounde's coat has not come to the cover before it was due. It has long lost all the freshness of newness, while sundry stains on the back and left shoulder give indications of lamp droppings, or wax swealings, obtained in the fantastic toe service. Still it is not a badly cut coat, though the collar rather puts the back to the blush, haring only superseded a black velvet one with a gold embroidered fox on each side, it shows rather too new for the rest. Of course Shabbyhounde sports an anonymous button, one we should think made entirely out of his own 
head; but he does not trust the keeping together of his coat to these usual articles, for he has it secured by a diminutive steel bit, which, with a curb chain to his watch, add, very materially, he considers, to his sporting appearance. No flash man was ever seen without pins or brooches, sometimes both, and Shabbyhounde has a large gold pin representing two race horses contending for a prize, in the full stride of extended limb. His cravat is a rich purple and black-flowered satin one, and his waistcoat a worked one, blue ground, with yellow roses. We need hardly add that he rides with a large cutting whip. $\mathrm{He}$ is a little man, though hunting dress has the singular effect of making some little men look taller and some tall men shorter than they are. Of course the Captain keeps his moustachios, this being part of his stock in trade, but he is not prodigal in whisker, neither does he indulge in flowing hair, at least not in winter.

We will now glance at him in action. $\mathrm{He}$ is always in a desperate stew about a start. His whole thoughts and conversation turn upon this point. $\mathrm{He}$ never cares to see the fox go away. He never looks to see whether the body of the hounds are out of cover, but as soon as a hound speaks, he begins to settle himself in his saddle, gets his horse firmly by the head, and keeps his eye on what he considers the foremost man to be ready to start the moment he sees him move. Thus he goes like a jockey, creeping to the starting post all arms and legs, jealous in the extreme if any horse's head comes before his. "Hold hard!" is the only hunting term Shabbyhounde knows, and most liberally he vociferates it when any one gets before him. It is a term, however, he pays little attention to, if he is firstthe Master not up, and an expectant purchaser in the rear. What places he will then go at! what risks he will run! 
A looker-on would fancy he had half a dozen spare necks at home, so little does he seem to care for the one he is wearing.

How amiable he is about his horses, how tender of their reputation, how anxious to transfer their faux pas to his own shoulders. We saw old staggering Bill, as he is called, a big, bay, wooden-legged old screw, give him a tremendous fall over a stone wall, which the old beggar absolutely ran at without the slightest attempt at leaping, and not content with tumbling him over on the far side, the indolent brute lay on his leg for some five minutes, which agreeable time was spent by the Captain in alternate exhortations to the horse to rise, and protestations to the parties who came to compel him, that it was "all his own fault; the horse wasn't to blame in the least." Another day he was riding a groggy old grey in a sharpish burst over a roughish country, where, as usual, the Captain was doing his best to distinguish himself, when in crossing a field of wheat, the veteran fell in a grip, and rolling heavily over him, left the Captain distended for dead. It is a painful sight to see a red coat and white breeches lying full stretch on the land, a painfulness that was increased in the present instance by the apparent lifelessness of the body and the springing of the young green wheat all around. There lay the Captain, and it was not until he was stuck up on end, and some brandy poured down his throat, that he began to give any symptoms of returning animation, when the first words he uttered, as he stared wildly around, were, "Good beast as ever was for all that." In short nobody ever saw the Captain without an excuse for a horse, whatever he did.

There are some people in the world, not many certainly, who have no idea of improving an opportunity-indeed upon whom the temptations of fortune are perfectly wasted, but the Captain is not 
one of these. We will give an instance of his observing acuteness and anxiety to "do business," as they say on 'Change. As he was getting on to his horse one morning, he saw a woman coming up with a pig in a string by the leg, after the approved fashion of pig-driving, and all sorts of dealing being interesting, she was accosted by a passing countryman as to what she had given for it. "Far o'er much," replied the lady, desirous of having the inquirer's estimate before she told.

"You'd give six-and-twenty shillings, perhaps," rejoined the man.

"No, a guinea," replied the lady.

Well, the Captain went to meet the hounds, and after drawing Copgrove Hanging Wood and Ashbourne Gorse blank, they turned in the direction of Harpsford, intending to go to Drewsborough Great Wood.

On the road coming down the Chequers Hill, what should Captain Shabbyhounde espy but his friend with the pig in the string, who, with that obstinate sort of stupidity called pigheadedness, was quartering the road as if to make the most of the journey. The Captain's keen eye saw "opportunity," and tickling o!d Beelzebub in the flank, he coaxed him in between young Tom Pappington and Miles Brown, who were enjoying an angry discussion on the corn-laws. Both being rather beat for arguments (indeed what they advanced were only the crumbs they had picked up at their fathers' tables), they were not sorry to transfer the further discussion to the Captain if he was inclined to accept of the boon. Accordingly they appealed to him for his opinion of protection, and the Captain prolonging a draw at his cigar - that most convenient of all idea furnishers -drawled out at length, as he watched the upward curl of smoke rise above his nose, that he thought repeal would bring down prices. 
"But," continued he, after a pause, during which he adjusted the end of the cigar, "you great landowners should know these things much better than me."

Piggy had now got near hand, and after a snort and semi-circular dart on meeting the hounds, had adopted the grass siding of the road, and was advancing in that sort of retrograding way that makes one congratulate oneself upon not being a pig-driver.

"It will bring down the price of bacon, too," observed the Captain, eyeing the bristling little beggar as it squeaked and tugged at the cord. "There's a nice little pig," continued he, pointing it out to Pappington. "What price would you set upon it?"

Pappington looked at it with a most sagacious eye, as if he was in the habit of valuing whole droves every day. fidence.

"Thirty shillings," said he, with the greatest con-

"What do you say, Mr. Brown?" asked the Captain.

"I say five-and-twenty," replied Brown.

"Let us make a sovereign sweepstakes," said the Captain, "for the nearest guesser."

"Done," rejoined Pappington.

"Will you be in?" asked the Captain of Sam Tubbs, who was just passing, to whom he explained the purport of the venture.

Tubbs, who was a judge of pigs, joined and priced the pig at four-and-twenty shillings.

The Captain guessed three-and-twenty.

"What did you give for your pig, my good woman?" inquired Pappington, riding up.

"Five-and-twenty shillings," replied the woman.

She had been hoaxing the man.

That was a spec deserving of a better result. We shall now exhibit our Captain in the more genial field of horse dealing. 
He once had a horse that he sold six times over in one year, receiving from each purchaser a bonus for taking him back. This was Lambkin, as he was erroneously called, though we really believe the name had considerable influence in selling him. Lambkin was a finely-shaped black horse about fifteen two, or rather under, a size adapted for hacking, hunting, or harness. The Captain either got him in a gambling debt, or from some officer ordered to join his regiment, we don't know whether. Suffice it to say, that in the season of sea kale and spring captains, Shabbyhounde cast up at Market Harborough with Lambkin in his stud. Now Lambkin really was a nice-looking horse-he was what we may call a creditable, gentlemanly-looking horse, in contradistinction to the blemished, iron-marked, knuckling, round-legged Tom and Jerry seedy-looking screws that generally composed his stud. With any man but Shabbyhounde upon him, the horse would have looked like a hundred and fifty or two hundred guineas, but spring captains are always suspicious creatures-such a spring captain as Shabbyhounde-suspicious beyond all conception. Many people looked at the horse, many admired him, many talked of him, and if Shabbyhounde had not been at Harborough before, he would very soon have sold him. As it was, he rather hung fire-everybody was satisfied that there was a screw loose somewhere, and most industriously they set to work to discover it. One thought his carcass was too big for his legs, another that his wind wasn't good-that he didn't cough as he ought, a third that there was an enlargement of the near knee, a fourth thought he detected incipient spavin, a fifth a little warmth in the off leg, a sixth that his feet didn't match, a seventh suspected incipient cataract, while the herd of greenhorns condemned his standing over legs, which were in fact one of the best points about hin. Tre are not like Luke Lieall, the 
"Cripplegate Pet," as he is called by the horse dealers, who invariably expatiates on the advantages of any infirmity about a horse that he wants to sell, but we may observe that real standing over legs, such as Lamblin had, are a recommendation. Standing over legs are of two sorts, the natural and the acquired. The natural, of course, are those with which a horse is foaled, while the acquired are the result of hard work, as are too strikingly portrayed by stage coach and cab horses, knuckling towards the ground. It is a truism for which we will vouch the great Tat himself, that naturally standing over legs never fail, while the others have too palpably failed already. That however is beside the subject. The question before the house is "what was the matter with Lambkin?" Well, reader, what do you think it was? D'ye give it up? Well, we'll tell you. $\mathrm{He}$ was difficult to mount!

We have already stated that he was good tempered - even playful-but he had his peculiarity, and that peculiarity consisted in kicking people over his head the moment they mounted. To further his amiable designs, nature had endowed him with the most powerful back and loins that erer horse possessed. Even in leaping, it required a good seat to keep in the saddle with the tremendous lashes out he gave behind, and the reader may easily imagine what redoubled force he would muster for a premeditated kick, and with what awful riolence it would tell on the unsuspecting confidence of a half acquired seat. Lambkin could spanghew a rider as clean as ever schoolboy spanghewd a sparrow from a trap. Send him flying through the air like an arrow or a darting hawk. It was only at the first mounting he did it. If the rider - or would-be rider-kept his seat-the horse would give in after a fight, a piece of politeness that tells more with a master than a stranger, seeing that the stranger, if he gets kicked off, in all 
probability will never be master. It was just one of those nasty sort of tricks that would prevent nine men out of ten from trying a horse.

Still, beau Shackell, Elmore, Bartley, Anderson, Bill Bean, a whole jury of horse-dealers, could not have detected anything wrong about Lambkin. His action was good, he could trot with a loose head on pavement, and in the field his performances were first-rate; first-rate at least with Shabbyhounde on his back, and a horse wanter behind. His temper too was perfect, and he had a playful way of rattling and champing the bit when he had nothing to do, as much as to say, "why can't you trust me without this nasty thing in my mouth." Whether it was this playfulness, or to disarm suspicion of his infirmity, we know not, but Shabbyhounde christened him Lambkin. Now the name Lambkin certainly does convey the idea of a very gentle, playful, docile creature, it disarms suspicion, nay, even inspires confidence, and would make one go up to an animal in a stall, that we might have declined had he been called "Beelzebub," "Old Nick," "The Tiger," or any such name. But Lambkin! who would be afraid of Lambkin! so great is the charm-the magic of a name. And yet his kicking was not from vice -it was a mere tricl trick that he had acquired with a sore back, and which had grown into habit by repeated successes. Before he came into the hands from which Shabbyhounde got him, he had spanghewd two prebendaries, a fat apothecary, a linen-draper, three ostlers, a master butcher, an official assignee, a railway surveyor, and two druggists. The uninitiated in "kicks off" may say that it makes very little odds whether a horse kicks you off from vice or from fun; but there we beg to differ from them, it makes a good deal of difference, especially if you fall near. The vicious horse will often follow up his success by attacking you either with his teeth or his heels, 
standing with his nasty frightful iron calkings at your nose, considering which eye he shall knock out; whereas the playful ejector merely seems to have been having a trial of skill how far he could send you, and stands looking at the result, just like a baker playing at bowls. The vicious horse to be sure gives a sort of notice to such few as are capable of taking a hint. There is a certain liberal display of the white of the eye, and a muscular cat-like contraction of the back and loins, all symptomatic of his intentions, but any misgivings arising out of such symptoms are generally allayed by those in the secret declaring that it's "all play"- "the quietest horse in the world when he's mounted "- "child might ride him "-with that most taking of all appeals to a Briton, "not to be frightened," an appeal that drives more men to destruction than even an engineman on a railway. Lambkin, on the contrary, gave no indication of anything of the sort. He would let a stranger walk up to him, handle him, gather up the reins, and even put his foot into the stirrup without wincing; but as soon as he felt the souce in the saddle, as surely down went the head, up went heels, and away went the intrepid adventurer. And yet, as we said before, Lambkin was not obstinately persevering, if he found he could not unship a chap, he would shut up shop, at all events, confine his endeavours to an occasional hoist; but a new customer invariably drew forth all his best energies, which he continued to use till one or other gained a decided victory. We need scarcely say, that Shabbyhounde had gained that desirable ascendency, and though he always found it convenient to ride Lambkin to cover, and was especially shy of mounting in the inn yard before strangers, yet that was from a desire of keeping the peculiarity snug, and not from any expectation of Lambkin proving "too many for him."

It has been well said that there is no secret so close 
as that between a rider and his horse, and as Shabbyhounde had no taste for disclosing the secrets of his stable, it will be abundantly clear that the only way of selling a horse like Lambkin-at least the only way of getting anything like a price for him-was selling him in the field, a process that the Captain was particularly partial to, especially after having "gone a good un" before the expected buyer.

Our readers will now have the kindness to consider it a fine morning in February, and the "Squire's" hounds meeting at Kelmarsh, a few miles below Market Harborough, on the Northampton-road. They will further oblige us by supposing that Captain Shabbyhounde having mounted Lambkin in the inn yard without more trouble than usual, has walked him quietly to the meet.

We took occasion lately, when sketching the portrait of old Mr. Bullwaist, to introduce the adventures of another horse-Claudius Hunter-and to comment on the admirable dispensations of Providence in turning even the infirmities of his creatures to good account, and in relating the adventures of Lambkin, we may observe how a never-failing supply of flats is kept up in the world-a fact most perfectly understood by advertising tailors, persevering wine merchants, and peripatetic map men.

It so happened that on this particular morning, the Honourable Julius Milksop, a newly emancipated, but beardless Cantab, made his appearance with the Pytchley in all the luxuriance of flowing locks, cheroots, and a perfumed pocket-handkerchief. Shabbyhounde's eyes, which had had "no speculation in them for some time, glared withal," for Milksop looked like a man for his money, added to which he did not seem to have any acquaintance in the field, so the Captain ascertaining from his groom who he was-a piece of information that the groom of course accompanied with the title of Honourable 
- "Honourable Milksop"-according to the then Cambridge idiom, why the Captain took him at once under his wing - a most prudent proceeding, seeing that it not only increased his own consequence, but prevented any of those illiberal remarks or insinuations that an opposition Shabbyhounde might indulge in. The Captain and Julius very soon struck up a dialogue, for Julius was just of the age to rush into indiscriminate acquaintances, and a youth-nay a man-entering a strange hunting field, is very like a fresh boy turned into a school-glad to take up with the first one that speaks to them. Since Mr. Lockhart went down into Leicestershire with his good little "bay horse," and wrote the surprising article on the "Chase," in the "Quarterly Review," people have been rather suspicious of strangers in the hunting field, and many a man has been charged with being a Quarterly Reviewer, whose banker's or whose betting-book has been his only claim to literature. Authorship somehow is not a popular trade in the country. Nimrod was the only author on horseback who could fairly face a hunting field in propria personce. There was no mystery or concealment about him. He went in as Nimrod, and as Nimrod he wished to be known. He even indulged in the lordly privilege of putting "Nimrod" on the backs of his letters. But to our story-the Honourable Julius Milksop is landed in Northamptonshire, and "taken up" by Captain Shabbyhounde, who, riding his best horse, had got his leather breeches on, and looked more like the gentleman, if not more like the foxhunter than usual.

After giving the hounds the usual run of the erergreens about Kelmarsh, and drawing Scotland Wood blank, they trotted away to a cover on some broken ground on a hill side belonging to Sir Justinian Isham, called Blue Devils, or blue something we forget what, when a whimper and the Squire's cheery 
holloa as he worked among the gorse on foot soon proclaimed the varmint astir, as was very soon confirmed by the crash of his redoubtable dog pack forcing their way to the spot. Presently Jack Stevens's halloo away! was heard from below, and joy and fear became depicted on every face. Scream! screech! twang, twang, crack, crack, whoop! whoop! all noise, bustle, and confusion-yonder he goes! Which way! over the hill! No, he's turned! Now d'ye see him? No, I don't! Yes, I do! No, it's a dog!

"Follow me, I know the country," cried the Captain to his pupil, as he hustled along, jostling two or three funkers out of their places, and leaping over the gorse and brushwood that obstructed his path, he dived down into the bottom. The Second Whip brought Osbaldeston his horse, and the Captain and Milksop start fair with the hounds, followed by all the bold boys of the county. It's a rare burst! and there's a rare scent!

It was worth going a long way to see Osbaldeston ride Pilot, or any of his

\section{"Cock horses to Banbury Cross,"}

followed by that best of good Whips, Jack Stevens, and our pen even now inclines to follow the Squire instead of sticking to the subject at the head of our paper-Captain Shabbyhounde. The Squire, however, and we must part for the present, for the Captain durst not ride before him, and his object now was to break the fences for his new acquaintance, and show what a wonderful horse he was on. Accordingly at the first divergible point the Captain struck off to the left, clearing four stiff rails instead of opening the bridle gate which they joined. Milksop followed him, for all lads like leaping, and they presently found themselves in great enjoyment among the bullfinches. 'The Squire's red coat on the right acted as a sort of guide, and first one, and 
then the other, went at the fences, as though they would eat them. Milksop was no shirker, on the contrary he would take anything that anybody else would take, and wanted particularly to distinguish himself. So Shabbyhounde and he went on from fence to fence, rejoicing.

As luck would have it, at the end of ten minutes or so the fox took it into his head to turn short to the right, but the Squire's hounds turning short also, they were getting together on the line, when our friends found themselves "right among them" before they

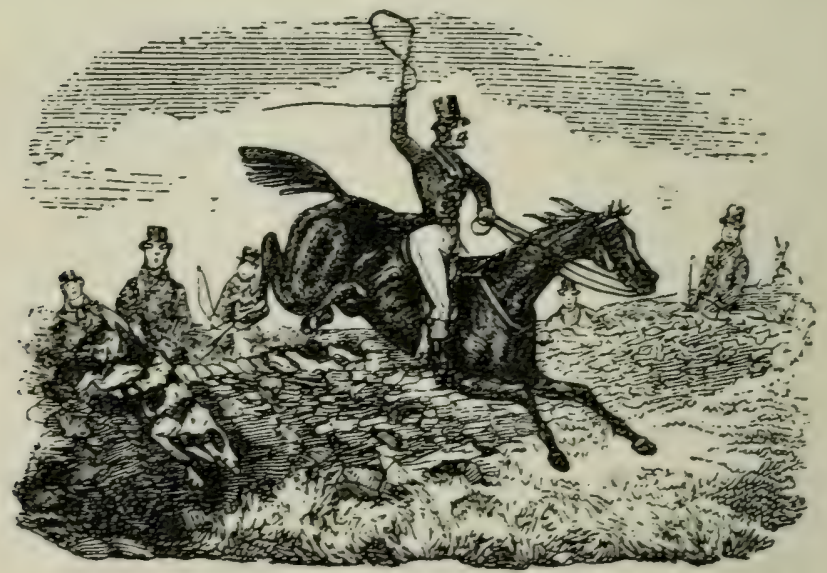

knew where they were. It is a general rule that when mischief is done, every person who is not in the place with the master or fault finder, whoever he may be, is wrong, and it required no rhetoric from the Squire to proclaim "that any but a natural born fool might be sure that the fox would turn where he did," but when the Squire came up and saw it was his old tormentor, Captain Shabbyhounde, who had ridden them to check, he began reading the Riot Act, most vehemently, exclaiming, as he held the hounds on across the enclosure, something about $\mathrm{d}-\mathrm{d}$ horse- 
dealing something-that did not sound at all like "gentleman." The scent was good, the hounds were quickly on the line, without letting in more of the tail than desirable, and away they went again full tilt. 


\section{CHAPTER XIX}

\section{CAPTAIN SHABBYHOUNDE-concluded}

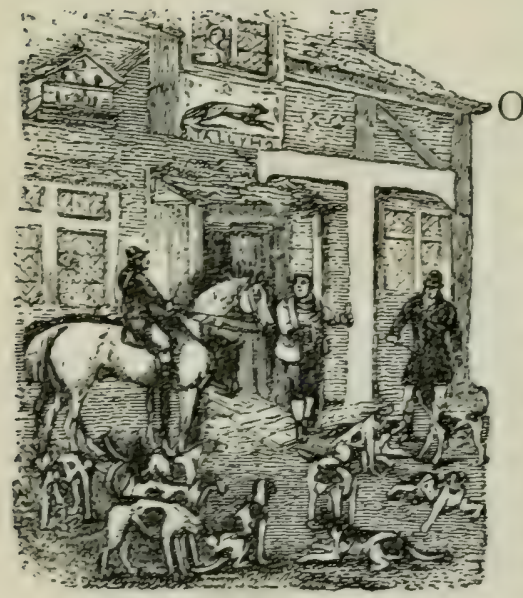

a stranger, or a man like Shabbyhounde, who never looks to hounds, a ring is as good as a line, and he reached Cottesbrooke, after running down nearly to Little Creaton, without being aware that they had not been going straight. At Cottesbrooke the pace increased, and the fox making for Thornby Folly, turned a little towards Naseby, and was finally run into in view in the large fields where the two cross carving knives on the map denote the battle to have been fought. The new friends rode gallantly together, at least as far as they went, nor was their cordiality diminished, by the partnership "blowing up" they had received from the Squire.

As luck would have it, Mr. Milksop's horse began to decline before they reached Thornby Folly. He blundered and tripped, and at last fell on his head on the far side of a fence. Shabbyhounde saw how it was, and having alighted, picked up and scraped 
his acquaintance, as the late Mr. Hood would have said, nothing would serve him but he would put Milksop on Lambkin. If the generality of the Captain's horses had only been as good on their legs as they were in their wind, they would have been invaluable, and Lambkin, for a wonder, was perfect in both. He had gone the run stoutly and well, was still as gay as a lark, and with Milksop's lighter weight upon him, bounded off like an arrow from the bow. Lambkin never thought of trying to kick Milksop off - that was only a home exploit; on the contrary, he scuttled away, and very soon was well with the hounds again.

Naseby Field used to be rather deep in those days —it may be so still, for aught we know-and after a fair trial, over sound springy pastures, Milksop found Lambkin had the knack of getting his hind legs well under him, and of going through deep also. What a luxury that is! How delightful to feel the hind quarters throwing the fore ones on, treading the water, as it were, instead of the floundering deeper and deeper still, lob, lob, lobbing, grunting, groaning, sobbing, sighing, hammer-and-pincering of the mere turf strider.

Give us the horse that can go in deep as well as on grass, the nag that can creep as well as fly, and we will throw extreme pace to "Bunbury," I to divide among the Jockey Club.

Forrard! forrard/ that inspiriting cheer to the fresh - that tantalizing mockery to the beat-forrard ! forrard! was still the cry, and Lambkin responded to it vigorously.

The Honourable Julius Milksop being in

"The morning of life,"

as the elegant Dr. Goss sublimely sings, when

"Middling horse-flesh takes the reason prisoner,"

${ }^{1}$ The great turf writer of the present day. 
it will not surprise our ancient readers to learn that he soon found out there was a considerable difference between the horse he was on and the one he had been riding, nor was the improvement less apparent, owing to the sudden transition from a beaten horse to a fresh one. Indeed Mr. Milksop, like many young gentlemen riding on the top of the morning, went a good deal upon price. He thought if he gave a good lot of money, he was sure to get a good horse, a problem not quite so apparent to those who have made a long journey in old Father Time's coach. The nag he was on was out of Jordan's stud, a fair hack hunter when in the superior wind peculiar to the class, but who had got rather pursey from a repletion of oats and deficiency of work since he entered our friend's (if he will allow us to call him so) service.

Yonder he goes / cried the Squire, pointing with his whip to where reynard was stealing over a gently swelling hill in the distance. Yonder he goes / repeated he, urging his horse on to the pack. The blood of old Furrier was in the ascendant, and the staunch pack clustered like bees-a sheet would have covered the whole. The fox gains the hedge-row, and is for a moment screened from view-another second, and he creeps through again, hearing hounds on the same side. Ah! it's all over with him. The hounds divide, and there's no escape. Whoo whoop! Vengeance snaps him!

A fox is one of the few animals whose death never draws forth compassion.

"Poor is the triumph o'er the timid hare,"

wrote Somerville, and hundreds will echo the sentiment who never feel a pang of compunction for poor reynard. The fact is, he is a carnivorous dog, and dies game. The scream of the hare is piteous in the extreme. Our fox will not excite any more pity, we dare say, from the fact of our having killed him twice. 
"A southerly wind and a cloudy sky" used to be the huntsman of old's delight, but we confess we have no objection to sun. We don't get so much of it in England that we can afford to shut it out even for hunting. Sun adds cheerful brilliancy to any sceneto a grand foxhunting finale as much as to anything. All nature looks smiling and gay. There can be nothing gayer or livelier than a well-grouped kill on a bright day, in the middle of a large pasture like those about Naseby. The led horses forming the outer circle, the dismounted red coats mopping themselves on foot, the huntsman, with uplifted for, in the middle of the baying pack, the echoing whoo whoops of the whips, and ever and anon the unexpected arrival of some unfortunate outcast brim full of excuses for not being up.

Such a scene was it on the day we have been describing. The Squire was delighted! All the "ups" were rejoiced, even the lagging lane and line riders were pleased with the country they had passed through, and all joined in testifying their unqualified approbation of the pack, and asserted their perfect readiness to be continually going before the Lord Mayor to make affidavit that Osbaldeston's were the "best hounds in England!"

Who, we should like to know, ever hunted with a pack that were not occasionally the best?

The Squire, seeing Mr. Milksop well up, and recollecting that he was one of the unfortunate wights he had "blessed" in the run, most politely handed him the brush, with an intimation that he had gone uncommonly well, and he was glad they had had such a good day for his first. The stranger having acknowledged the compliment, and tipped Jack Sterens a sov., as Jem Bland used to call them, sought his led horse, and, brush in hand, retired from the field in quest of his own.

We must now return to our friend Captain Shabby- 
hounde. The Captain got Mr. Milksop's horse just in time, for the pace they were going, and the loose way Mr. Milksop rode, would have polished him off in another field or two.

He was not the first tired horse the Captain had had through his hands, by many, indeed the generality of his stud exhibited the sunken, dejected eye, peculiar to stopped and over-marked horses. By slackening Milksop's horse's girths, turning his head to the wind, rinsing out his mouth, and other little attentions, the Captain was soon enabled to pursue the chase on foot with his horse in his hand.

Hunting on foot is only poor sport at best, pursued in top boots lamentably poor, and the Captain was not sorry to see his new acquaintance returning on the line of the run. Great was his joy when the proud trophy waved over Milksop's head proclaimed the glorious finish, and greater still, though more suppressed, his delight at hearing that Lambkin had "carried him well."

What an opportunity was here for a man of Shabbyhounde's enterprising qualities-what a field for the exercise of his "insinivating" talents. A youth, as fresh and verdant as a turnip-field-a splendid horse-a clear stage, and no opposition. Could but the Captain have had a peep at the banker's book, he would indeed have been elated. That was his only fear. He had once been bit by an apparent greenhorn in the matter of a post obit, and he rather dreaded the innocence of youth. "Nothing veuture nothing gain," however, thought the Captain, and he "at him" again with the virtues of his horse. If ever animal had cause to be proud of the favours of a master, it surely was Lambkin-Shabbyhounde did butter him up-did lay it on thick. Not but that the horse deserved praise; for he was a "goodun," and nothing but a "good-un," barring the little playful propensity already related. Indeed, Shabby- 
hounde laid it on so thick that Milksop, who was most "jolly green," thought it useless asking if he would sell such a piece of perfection. The consequence was the Captain was obliged to throw out the bait himself, a decidedly unskilful move in the grand game of "Do." However, there is no help for it, where such verdancy does exist, and the Captain was obliged, after sundry beatings about the bush, to put it to Milksop rather pointedly "if he would not like to have Lambkin?" "There are very few people who can't take a good horse, the difficulty generally being about paying for him; but this did not seem to weigh with Mr. Milksop, who merely said he would be glad to take him-" fuke him," just as he would take a hat from a hatter, a pair of braces from a hosier, or a waistcoat from his tailor. That fine, easy, Cantebridgrian style of doing business not sounding at all like money, and "tick" being at all times abhorrent to the mind of our Captain - at least when he had to give it-and dangerous in the extreme in a case like the present, he let out at once that the price would be a hundred and seventy-five guineas.

Milksop didn't seem chagrined at all at the information; indeed, he rather looked upon the price as complimentary to his judgment in horse-flesh, seeing that he pronounced Lambkin first-rate, and he had given a hundred and twenty for the horse he was on.

We think the Captain showed great judgment, not only in asking a high price, but in asking it in such a way as to look as if he had measured the horse out to the odd five guineas. Had he asked a hundred and ifty or two hundred, it might have been regarded as a mere random, off-hand, tigure-of-speech sort of price; but a hundred and seventy-tive guineas carried considerate calculation on the face of it. Time was. when gentlemen used not to think it right to offer each other less for their horses than they askedthey used to leave bartering and bargain-driving to 
jobbers and dealers-but those days are about past -gentlemen haggle just as hard as the hucksters. To this rule, however, we must add that Mr. Milksop was an exception. His father, old Viscount Creamjug of Papcastle Tower, had instilled good old-fashioned gentlemanly ideas into his mind, and Mr. Milksop invariably acted up to them. Honourable himself, he had no suspicion of dishonesty in others-a fine healthy feeling, but one that is not exactly adapted to this extremely sharp world of ours. Be that as it may, the Captain got his price, and how the horse turned out will soon appear.

Captain Shabbyhounde, like most of the puffing, advertising tradespeople, not expecting to do business with the same person a second time, always made a point of bilking the groom, when he accomplished a sale by himself, and he did not depart from his custom in the present instance. Indeed, there does seem something superlatively silly in feeing a servant, because we have taken it into our head to buy a horse. We might just as well fee the housemaid on buying a broom, the dairymaid on buying a cow, or the man or boy on buying a hat.

Nobody who knew the Captain, or rather no one who did not know him, but who heard him talk, could doubt for a moment that his objection was founded on pure principle. He denounced it as an absurdity, as a mere premium for dissatisfaction, and the urging of frequent changes on the part of servants.

When, however, the deal was not to be accomplished without, our friend knew how to plant a sovereign, or even a five pound note, as well as anybody. The Captain indeed was the creature of circumstance, now liberal, now mean, just as it suited his purpose. The character is a common one, and we need not describe it further.

When Mr. Strutt, Mr. Milksop's valet and studgroom, heard that he had presumed to purchase a 
horse without consulting him, he was highly indignant. Strutt had had cause for dissatisfaction before, and it was only not seeing his way clearly to a better place, that prevented him turning his master off. When he learned that his master had dealt with Shabbyhounde, he looked upon himself as regularly robbed. It may seem strange that Mr. Strutt, who had so lately arrived, should be "up" to the Shabbyhounde dodge; but Strutt was a high privilege man, one who stood upon the rights of his order, and he considered it a downright insult for any man, be he who he might, to attempt to "do" his master without consulting him. He took an enlarged comprehensive view of the question-not the mere "A and B" deal case, as between Shabbyhounde and his master, but he looked at the general principle of the thing, and he saw if such work was allowed it would be destructive of settled principles, and most prejudicial to the interests of his profession. Moreover, Shabbyhounde's fame was not altogether unknown to him, though it did not enter into Strutt's imagination that a man could be so depraved as to think of defrauding him of his regulars; the amount of which, however, he could not but feel greatly depended upon the imparlance before the deal. It is a delicate case, and one that we feel assured will come home to the feelings of all stabularian professors. It makes all the difference in the world, whether the imparlance is before or after the deal.

Strutt looked as though nature had meant him for the name, for he was a most bumptious, consequential, rosy-gilled bantam cock-looking little fellow, uniting in his apparel the extravagancies of valet and groom. He had a groom's hat and a valet's hair, a groom's coat and a valet's waistcoat, a swell satin cravat, and groomish made trowsers, buttoning up the leg with French cut gaiters and thin shoes. At the time of which we are writing, he might be forty or forty-five years of age, greyish about the whisker, 
but not about the hair, pot-bellied, and uncommonly "long in the tooth." He knew where sixpence could be laid on, or a shilling squeezed out, as well as any man going. He had been Lord Creamjug's "own groom," and had been selected by his lordship to accompany his son to Cambridge, in the advanced capacity of valet and groom of the one horse his lordship thought would assist in digesting his son's mathematics, and other cross-grained stuff that he had to encounter with his mental teeth.

Of course, Strutt had improved his own education and knowledge of arithmetic among the highly respectable tradesmen and "talented" men congregated at Cambridge, and at the time of which we are speaking you might have drawn Piccadilly and Oxford Street too, without finding a more "knowing hand" than Simon Strutt.

Of course, Strutt had now nothing to do with what he called the "dirty work" of the stable. The stud had increased to four, for which he had the second horseman, a regular helper, and as many occasional ones as he chose to take; Strutt superintended. His valeting was onerous. He attended to all his master's clothes, except his hunting and shooting things, his morning boots and shoes, dirty trowsers and gloves. Those he assigned to the second horseman. He gave the linen out to wash, and counted it or not when it came back as suited his convenience. Altogether, Strutt—we beg his pardon, Mister Strutt-had a hard easy life of it-laboriously idle.

Strutt, we need not say, was desperately indignant when his master informed him that he had bought the "sweetest horse in the world," and when he mentioned the name of Captain Shabbyhounde, his gill-less chops reddened like a turkey-cock's thropple at the sight of a scarlet coat. He did not like captains in general, or the name of Captain Shabbyhounde in particular. Our readers may suppose how much he 
was disconcerted, when he committed himself by writing the following letters:-

"George Inn, Northampton.

"Sir, - Understanding the Honourable Mr. Milksop has been looking at a horse of yours, i shall be glad to kno when it will suite you for me to com orer and examine him and so on, yours to command,

"Simon Strutt, Stud Groom.

"To Captain Shabbyhounde, Market Harborough."

The Captain replied as follows :-

"SIR,-Your master has bought my horse, and he only remains in my stable to suit his convenience, and save the horse a journey southward, when he is going west. He had a hard day at Kelmarsh, and as we thought he would not be fit for four or five more, we arranged that he should stay here, and I would send him to meet you at Dunchurch on Friday, where Mr. Milksop proposes riding him with Mrr. Osbaldeston's hounds on Saturday. - Yours obediently,

"George Shabbyhounde.

"To the Honble Julius Milksop's Groom, Northampton."

We should have premised that Mr. Milksop was a mere bird of passage, hunting his way to Leamington Priors, where the Viscountess Creamjug had gone in a terrible hurry, suffering from an affection of the toe (what common people would call a corn), which she preferred placing under the silent treatment of Doctor Jephson, to undergoing the public gibbeting of Monsr. Eisenburg, or any of the advertising fraternity.

Before Captain Shabbyhounde's answer reached the anxious hands of Mr. Strutt, that vile jade rumour had spread some very unpleasant stories respecting the Captain's mode of doing business. Indeed it appeared that a jury of grooms had sat on him only the season before, when they returned an unanimous verdict that he was a "snob," and strongly recommended that he "should be transported back to the country from whence he came, being totally unfit," as 
they thought, "for a civilized one," a sentence, we may add, that they would have had some difficulty in carrying out, seeing that no one had ever been able to tell what country claimed the Captain. That case had originated in much such a transaction as the present-an unprincipled attempt to defraud a man of his regulars. Indeed the cases were so analogous, that it was agreed in consultation that unless the Captain was brought to book before the horse was delivered, there would be very little hope of getting anything after. That impression was quite confirmed by the receipt of the Captain's reply, which did not even hint at doing the "usual" or the "genteel," or anything that could be construed into an acknowledgment of vested rights. Strutt was outrageous. He was so put about that he could not take the chair at the Grooms' Champagne Club, which was to hold its weekly meeting that night.

Instead of going, he concocted the following letter. How many he cancelled before he got one to his mind, it is immaterial to say:-

"SIR,-I beg to acknowledge your letter respectin the horse which is quite satisfactory. i was not awar the honble had gone so far in the matter. The honble is a very honble gent in horse. dealing, but not quite up to the thing, and i am sponsible to the Right Hontsle Lord Viscount Creamjug for the honlles safety and neck and limbs and other particklars i should like to have him passed by a ret, and i will thank you to send me his ped: along with him. Hopin to have further dealings. - I am, Sir, your respectful servant,

"Simo.: Strutr, Stud Groom, Northampton.

"To Capt George Shabbyhounde, Market Harborough."

"P.S. The honble not being up to snuff, it may save trouble if you will say what kompliment i may kalculate on, so that $\mathrm{i}$ may kalculate the kompliment due to your groom. We wish of course to be quite genteel."

Captain Shabbyhounde was not such a fool as to indulge in the "pleasures of hope" of having a second 
deal with Mr. Milksop, therefore he saved Strutt the expense of a "rule to compute" by not returning any answer to the letter.

The showman will now change the shade, and the intelligent and accommodating reader will have the kindness to accompany us to the "Cow" at Dunchurch.

It was midday, and Mr. Strutt was airing his little round stomach before the inn door, indulging in one of his master's Havannahs. The weather was still fine, rather unseasonably so if anything, and Strutt, like a good servant, was also airing a cut tartan velvet waistcoat of his master's, which fitted him marvellously well, considering the disparity of their corporations. $\mathrm{He}$ had also a shirt with a very finely-worked front on, and three diamond studs secured by a diminutive chain down the middle. Altogether he looked as full of beans and consequence as man could possibly do, a gentleman that none but a public body-the Bank of England, South Sea House, or some such establishment, could purchase, if taken at his own valuation. What a contrast to the lean, haggard, lank-haired, one-eyed man coming up on a worn-out pony with the redoubtable Lambkin in his hand. The old, napless, seen-better-days looking hat of the stranger is put out of all countenance by the spic-and-span, fresh-from-the-band box, blooming-looking affair on the well-anointed curls of the smoker. "Well to do" must the man be who turns out a new tile in February, tempting not only the snow, but Jupiter Pluvius. This, too, Strutt did, in spite of the redoubtable Moore having prophesied in his wonderful weather column, "Now dull with frequent downfall." Strutt, of course, found his own clothes, and affected a sort of mixture of the foreigner and the country gentleman. Not so the stranger, whose seedy old drab coat and broad blue-and-white striped livery waistcoat, put all jdea of concealment of servitude out of the question, 
even if the shabby cockade in the hat had been wanting.

"I'm blowed, if I don't believe this ere kiddey with the ventilator in his old tile is a bringin of my new 'orse," observed Mr. Strutt, taking his cigar out of his mouth, with which, and a hand in each coat pocket, he had been straddling, the observed of all observers of a select circle of post-boys, horse-keepers, and idlers, the usual concomitants of the glorious but now departed greatness of stage-coaches.

"I say, old chap!" exclaimed Strutt to the man who had now begun fumbling and smelling at the piece of dirty paper as if he could read, "I say, old chap, are you a lookin for your nuss?"

"Brought a horse for a gentleman," replied the man, again holding the dirty slip of paper upside down before his nose.

"Here, let me see it," said Mr. Strutt, perceiving how it was. He took and read as follows:-

"The Cow at Dunchurch. Ask for the Honourable Mr. Milksop's groom, and deliver the horse to him."

"I thought so," said Mr. Strutt, tearing the paper up, and giving it to the winds. "I thought so," repeated he, looking at the horse.

"And have you no letter from your master?" asked Strutt.

"No," replied the man.

"No!" repeated Strutt. "What! no letter, no message, no nothing?"

"No!" was all the answer returned.

The "gemman wot does our shades" would not like to have them dulled by recording the oaths that followed. Suffice it to say, Strutt saw his worst fears were realized, and stormed and fumed accordingly.

The horse, too, came in for his share of abuse. What was the use of bringing such a d-d cat-legged, cow-hocked, sickle-hammed, leg-tied, spavined, glan- 
dered, broken-down rip of a brute to him! He didn't 'orse a coach! He didn't keep a cab!

Poor Job Tod, the spectral groom, had lived in many bad places, and had had too many blowings-up and blackguardings to care much about one now, so finding he had got to his customer, he sought the ostler, who conducted him to Mr. Milksop's stable, where, notwithstanding Mr. Strutt's asseverations that he would not receive the horse without his pedigree, warranty, and we don't know what else, he nevertheless let the second horseman lead him quietly in. Strutt's bumptious, inflated, cock-sparrow manner - his full rubicund face and boisterous action, contrasted with the lean, haggard, pensive looks of the ill-fed, ill-paid stranger, whose wrinkled, cadaverous cheeks were innocent of colour, whose old, misfitting clothes hung on him like sacks, and whose short parchment-looking leathers and tightly-pulled up boots, were a world too wide for his shrunk shanks. The poor creature did not look as if he had had a good meal for a month, and most likely he had not; for the Captain gave him but twelve shillings a-week, and he had himself, a wife, and three small children to keep out of it. How meek, passive poverty is imposed upon in this world! And yet the poor creature was faithful, faithful even to the Captain-early and late at his stable, careful and patient with his horses, attentive to the last comer as to the first; his regard for the animal seemed to extend to the whole equine generation.

The Captain was not the man to tell his right hand what his left hand did; but if he had, we really believe he might have trusted Job Tod. He would have kept his secret. Indeed, nature seemed to have meant Job for the secret service department; for if ever there was a silent, uncommunicative, monosyllabic creature, it was Tod. "Yes" or "No" seems to constitute the stock of his vocabulary. Honest as Aristides, and always as poor; patient, attentive, 
watchful, without being inquisitive, he served even Shabl,yhounde with all the faithfulness of affection; yet he harl never risen much above the rank of a horse-dealer's man. The reader will see why. Job's manner and appearance were against him-he had but one eye and no tongue.

Strutt, however, was not deficient in that respect. Having abused every limb and every look about the horse, he turned the voluble battery of his tongue upon poor Job, whose master he belaboured, through him, in a most exemplary way. Job, however, as we said before, cared little for that sort of thing, and having retraced his steps to Harborough, and returned the pony to the butcher from whom he had borrowed it, he betook himsclf to his stable, just as if he had only been along at the post office.

"Well, Job, you've got back," observed his master, entering the stable at four o'clock.

"Yes," replied Job, as he knelt, hand-rubbing one of the ticklish-legged stud.

"Did you see the groom?"

"Yes," was the answer.

"What did he say?"

"D—d me well," replied Job.

Change the shade again, Mr. Showman, and put us in the one exhibiting Strutt coming out after dinner fuller than ever of beer, brandy, baccy, and blackguardism.

That's your sort, Mr. Showman; now we'll go on again.

"Let's see the d-d cripple out," says Mr. Strutt, swaggering into the yard, hallooing out, "Here, Tom! John! James! ostler! what are you all about?" "Saddle me that orse," exclaims he, as his authoritative voice brings out the whole crew with their mouths full, they having been regaling in the kitchen with what had come from the "bar table."

"Take off my strapss," said he, cocking up a leg to 
a newly caught helpe:. This is a proceeding, by the way, we never could understand. We have almays imagined that the use of straps was to keep the trowsers down in riding, but we see certain of the XX knowing ones always cake theirs off beiore mounting. The obedient helper quickly had Strutt divested of his.

"Bring me the honourable's riding whip," continued he, "you'll find it on my dressing-table. and put them "ere straps there."

Here let us pause for a moment to observe on one of the absurdities of the day. We keep a barometer of impudence, and we find that when servants begin to call their masters and mistresses by their names, as Mr. Brown, or Mrs. Green, instead of "my master" or "my mistress," they are generally getting above themselves, and want taken down a peg or two. Time was when such phraseology was unknown: but that was before grooms drank champagne, or housemaids wore artificial flowers and veils. The fact is, however, the whole system of servitude is gone wrong; but servants are not the only parties to blame for that misfortune. Simon Strutt called his master "the honourable," because being the servant of a lord's son reflected honour on himself. Had he been plain "mister" he would have called him "my boy," or "Milksop," or any other term of familiariy. "Mrr. Brown," or "Mrs. Green," we mean to observe. is a before-your-face style of expression, instead of the old one of "master" or "mistress."

Now for the last shade of all that ends this strange eventful story.

Lambkin quickiy made his appearance, looking all the better for his leed of com and entry into the stable. Even Strutt, prejudioed as he was, could not but feel that he was a nice looking horse.

Tom, the helper, sidled him up to where Mr. Scrutt stood, and with one hand at the bits, the other 
at the stirrup, and the clean towel over the left shoulder, held Lambkin for the great little man to mount.

Mount he did, but ere his right foot gained the stirrup, Lambkin, with one of those tremendous efforts, sent him flying several yards, pitching him head foremost in the pit of old Marjory Daw, the Banbury cake woman's, stomach, who, unfortunately for herself, was passing by at the time.

What a hubbub was there! How the women screamed! how the men stared! Gilpin's celebrated ride to Edmonton did not create greater sensation on that line of road than did Simon Strutt's summerset.

It was an uncommonly clean thing.

The most provoking part of a "kick off" is, that nobody can help laughing-great as their anxiety may be, still the laugh will out. That is very odd, for people do not laugh at each other when they tumble out hunting, and yet they generally fall much softer and dirtier, and consequently with less chance of being hurt than the victim of a deliberate kick off. "More dirt the less hurt" is a sound hunting axiom. In this case perhaps, there were more than the usual provocatives of laughter. There was a little bumptious, over-dressed, cock-sparrow looking thing, pitching like a cannon ball into an old cake-woman's bread-basket. Old Margery was floored-regularly doubled up-her Banbury cakes were scattered all over the road, while the concussion sent Strutt's head right into his hat, knocking the crown clean out, and leaving him with the rest of the hat over his face, looking just as if he were going to have a game at blind man's buff.

$\mathrm{Ye}$ gods, what a rage he was in! How he did stamp, and splutter, and groan, and kick, and swear he was finished! The scene was ridiculoustoo ridiculous to pursue, so we will chop over to the Captain and his doings. 
The Captain's acute mind on hearing Job Tod's laconic account of what had passed, saw there was a chance which, industrious as he was, he determined not to throw away. Accordingly he addressed the following letter to Mr. Milksop, and sent it in a parcel by the next "up" coach to Northampton, where Mr. Milksop had to sleep:-

\section{"(Private and Confidential.)}

"DEAR Sir,-My groom having just reported to me that your servant Strutt was very dissatisfied on the delivery of Lambkin, it has just occurred to me that it is possible he may play some tricks with the horse so as to prejudice you against him, and I therefore think it due to myself to give you this hint on the subject. His dissatisfaction, I imagine, arises from my not complying with a most absurd custom of tipping him because you bought my horse, a system too much pursued, I am sorry to say, by parties with lame or inferior horses, in order to get the servants' good word with their masters. That is a sy'stem that has always been strenuously opposed by,

" Iy dear Sir, your most obedient, humble servant, "George Shabbyhounde,

"To the Hon. Julius Milksop, "Market Harborough. Northampton."

There never was a more perfect master-stroke of policy than that of the Captain. Generally speaking, it is a foolish, thankless office, giving a man a hint about a servant; but in the Captain's case it was a dashing venture where he could not lose. Besides we have already stated that Strutt had cause of dissatisfaction with his master, who had shown certain rebellious symptoms, all inclining towards haring more of his own way; and of course what was unpalatable to the man, would not be altogether lost upon the master. In truth, Strutt did not accommodate his carefulness of the boy, to the growing independence of the man, and Mr. Milksop had once or twice gone out of his way rather to let Strutt see that he was not to have the upper hand. The Captain's hint, therefore, was not likely to be 
thrown away. Nevertheless, Mr. Milksop had forgotten all about it, as in the enjoyment of the "balmy breeze " of a fine hunting morning, he cantered up to the Cow at Dunchurch. What did he see! Strutt, instead of standing with his usual patronising air, with a couple of jean-jacketed helpers behind him, acknowledging his presence with a finger to his hat, appeared in an old cloth foraging cap, with a blue pocket handkerchief bound over his left eye, while the other exhibited symptoms of going into mourning.

"What's the matter?" exclaimed Mr. Milksop, pulling up in astonishment.

"Matter!" replied Strutt, with the dignity of a deeply injured man; "matter, by God!" continued he, "I've pretty near lost my precious life with that ere blasted rip of yours."

"What rip?" asked Mr. Milksop, who knew the term to be one of general application.

"Why that d-d beast Colonel Scabbydog, or whatever they call him, has stuck into you."

"What, my new horse!" exclaimed Mr. Milksop.

"New Derill" retorted Mr. Strutt, "he's as ricious as a whole caravan full of tigers."

"Ticious!" repeated Mr. Milksop.

"Vicious, ay, vicious," reiterated Strutt, with an emphasis, "he nearly killed me-most pulled the stable down-takes ten men to hold him-'bliged to put his corn down through the rack."

"God bless me, you don't say so!" observed Mr. Milksop, quite disconcerted. "You are none the worse though, I hope," added he, looking at the little great man's dejected appearance.

"ITuss!" exclaimed he, his impudence rising with his master's consideration. " If uss," repeated he, with a shake of his head and shrug of his shoulders, "never had such a shake in mv" life, I know. Wish I may ever get over it." 
"Well, but what am I to do?" asked Mr. Milksop, seeing the hounds were about to leave the meet, "I was going to ride him, you know," added he.

"I intend you to ride Apollo," said Strutt, with his usual consequence, "he's all ready-here, Tom!" exclaimed he, "bring out the orse!"

When the hounds were drawing Birdingbury Faggot Cover, who should appear but Captain Shabbyhounde, and with his appearance returned the recollection of the over-night letter. Shabbyhounde's quick eye saw at once it was a "case," but Milksop's countenance, as he hurried up, had more the appearance of a man wanting information, than the lowering sulky scowl of one who has been "done." The Captain was a second Lavater in physiognomy.

"Tell me," said Mr. Milksop, in the hurried way men speak on the eve of battles and fox-hunts, "Tell me," repeated he, "is that horse of yours vicious?"

"Not the least!" exclaimed Shabbyhounde, with emphasis, squeezing Milksop's proffered hand.

"TALlyHo: gone away! hark, halloo! hark! hoop! hoop! crack! crack! crack ! hold hard! go on! Now, sir! Do go on or get out of my way! I'll ride you over!"

Away for the Shuckborough hills, and Merston Priors, and across to Ladbrooke Gorse, where the hounds killed their fox, or another, which did quite as well, ere our friends had time to finish their confab. Once indeed

\section{"They met, "twas in a crowd,"}

the majority of whom were craning at a wide brook, and as Shabbyhounde and Milksop beat simultaneously on the opposite bank, the former flourishing his whip, exclaimed in joyous exultation at the feat, "Not a sweeter tempered horse in the world, by God!" but a paralyzing bullfinch immediately 
intervening, stopped all further intercourse, and they saw no more of each other till the end of the run. Not that either of them shirked the bullfinch, but they got through at different places, and it is much easier to part company than get together in a run. The pace was severe. Quickest thing that ever was seen! All quick things are. Every season furnishes a bushel of them. "A fellow feeling makes us wondrous kind," they say, and in no case is the truth of the adage more strongly exemplified than among foxhunters.

We often think if Frenchmen had a turn for hunting, what hugging and kissing there would be on a kill!

Shabbyhounde and Milksop had each "gone a good-un," and some time was consumed in discussing the delightful variety and size of the leaps ere Mr. Milksop again bethought him of recurring to Lambkin.

Shabbyhounde assured him he was the most perfect tempered horse he had ever had in his stable, and though it would be going out of his way, he offered to accompany Mr. Milksop to Dunchurch to prove it.

Had Lambkin been troubled with hydrophobia, he could not have been more tightly secured than they found him. Tied short up to the rack, and hoppled both before and behind.

"What's all this about?" asked Shabbyhounde, following the disconcerted Strutt into the stable.

"Vicious!" retorted Shabbyhounde, in reply to Strutt's asseveration- "not half so vicious as the man that put those on," continued he.

Strutt, for once, was taken aback.

The Captain proceeded to liberate the animal, whose trembling, frightened manner, showed he had been abused. All abused horses show this, if masters 
would but take the trouble to observe them. Nevertheless there are more savage servants in stables than nine-tenths of the world imagine.

It would be impertinent in us to trouble the sagacious reader with the denouement of this deal in detail. The most rusty-brained, wooden-headed cock among them, must anticipate that the Captain was too many for Strutt. The fact of the horse having been taken out, coupled with Strutt's assertion of his viciousness, and the Captain's wily insinuation by letter, all tended to a hasty dismissal, which was not even softened by the stale trick of being allowed to give up the place himself on seeing he was going to lose it. Strutt was chassaed.

Having had occasion, however, to exhibit the Captain in not the most enviable colours, to avoid the imputation of painting human nature "too sererely true," we will add something that may be placed to his credit. Finding Mr. Milksop was not sufficiently strong in the fork to compete with the vigorous efforts of Lambkin, and knowing that his recent success over Strutt would only add fresh fuel to the fire of his exertions, the Captain kindly gave Mr. Milksop the pick of his stud in exchange, and Milksop got a very fine $£ 3 \circ$ piece of antiquity that was worth "any money," if he only stood sound. Shabbyhounde's disinterested benevolence carried him still further. He accommodated Mr. Milksop with Job Tod, though helpers' wages had riz from twelve to fourteen shillings a-week, and he could not hope to supply Job's place under this latter amount.

Job, it may be thought, was not exactly the man for the heir to a peerage, but when a master has been racked by the forward, loquacious, tormenting impertinence of an officious, presuming puppy, he is very apt to fall into the other extreme in the choice of a successor, and Job, it must be admitted, was the very antipodes to Strutt. Job was too old and too strongly 
stamped by nature to change or be spoiled, though good clothing and diet soon made a very different looking man of him. Indeed so pleased was Mr. Milksop with Job, that he looked upon Captain Shabbyhounde in the light of a benefactor, and the piece of antiquity fortunately keeping on his legs, Mr. Milksop was not at all sorry to see our hero cast up at Leamington, where the recital of his kindness so touched old Lord and Lady Creamjug, that Shabbyhounde absolutely had the honour of dining with them!

But we must dismiss this illegitimate member of the hunting field, who has occupied more of our space than any of the real worthies who have preceded him.

Captain Shabbyhounde, adieu!

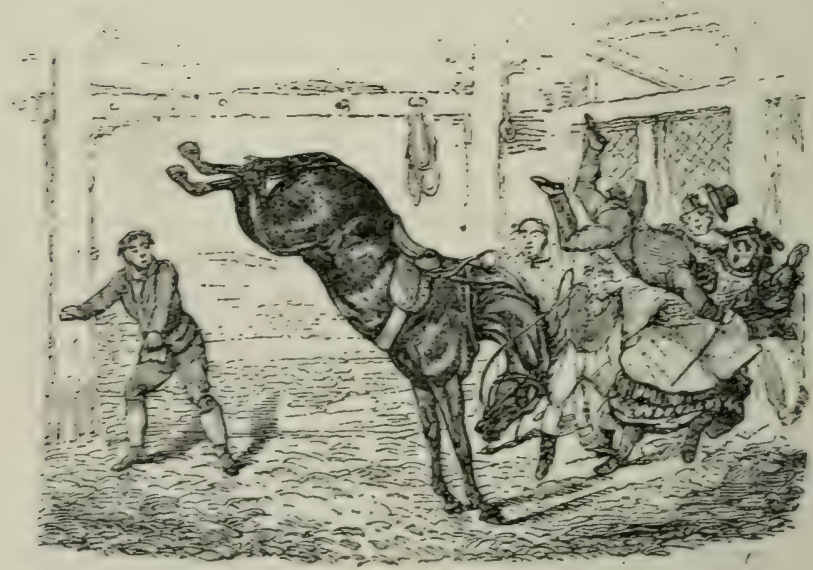





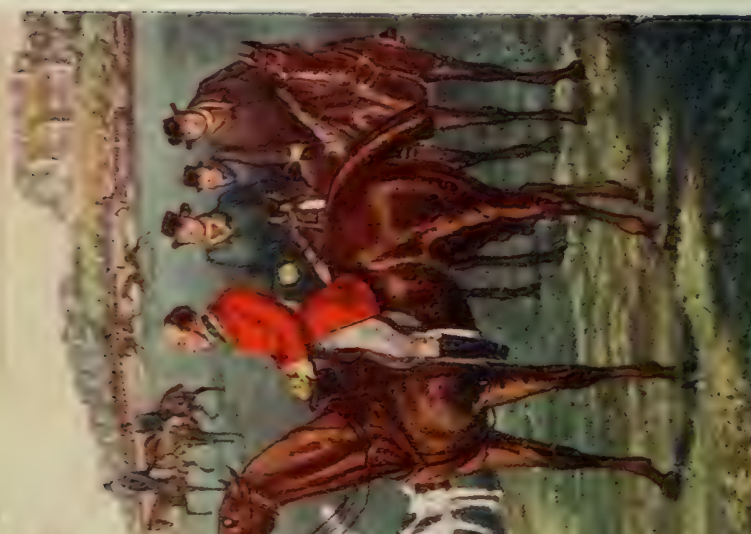

:

$\frac{4}{3}+2$

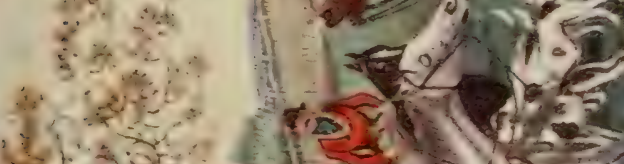

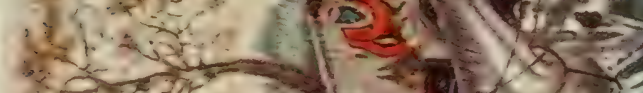

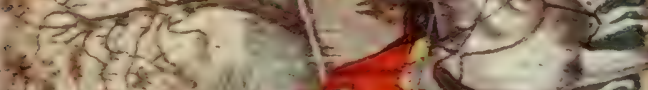

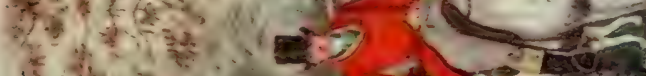

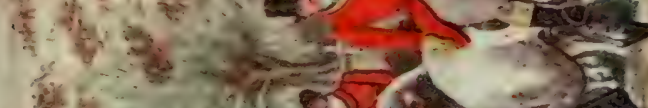

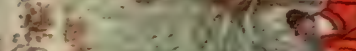

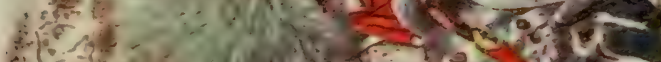

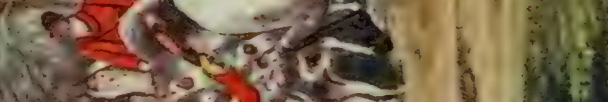

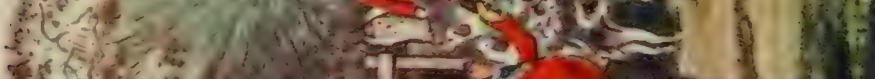

If

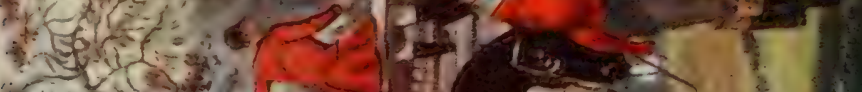
$\frac{1}{1.0}$ 


\section{CHAPTER XX}

\section{LADY FOXHUNTERS}

SIR RASPER SMASHGATE AND MISS COTTONWOOL

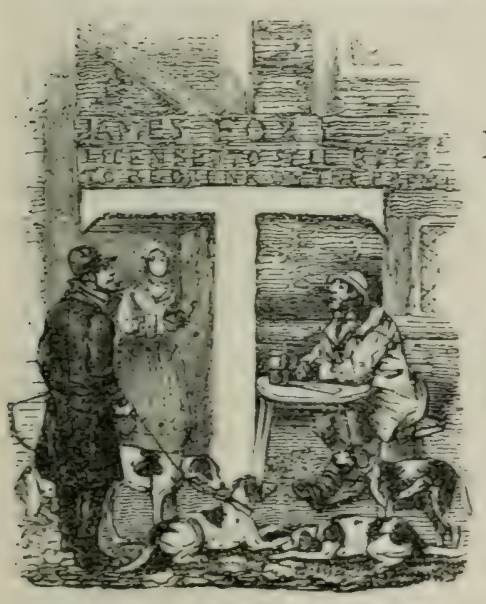

HERE is nothing we hate so much as seeing a woman lolling alone in a carriage with a lapdog sticking out of the window. It is the picture of deserted dejection-of utter loneliness, friendlessness, and solitude.

Carriages are now so multiplied that not keeping one is the singularity instead of keeping one the wonder. Roads are so good that we can get almost everywhere upon wheels; and feet and horses-saddle horses at least-are about in equal disuse. Tie should like to see a return of the number of carriages kept now, and the number that were kept a hundred or even fifty years ago.

Considering the luxurious inert lives many of our highest aristocracy lead, it is wonderful that they still retain their superiority of appearance. That possible exercise can there be in lounging on a soft cushioned, easy hung carriage, for two or three hours in the day, 
grinding up and down by the Serpentine, or, what is worse, hurrying from house to house, changing from hot rooms to cold air, and from cold air to hot rooms - carved ivory card-case in hand, making what they call "calls." Surely this system of cold-catching must have been invented by the doctors for the purpose of procuring patients. No wonder dashing ladies think so little of their poor horses and servants shivering in the cold and night air when they are so regardless of themselves.

It is said that caricatures contain in a manner the history of the times, and much such an observation may be applied to inn and public-house signs. IVhat should we have thought fifteen or twenty years ago of the sign of the Railway Tavern or the "Locomotive Inn" depicted, with its hissing engine, and a long train of railway carriages after it, and yet it has become quite common, superseding our ancient friend the pack-horse. "The pack-horse" was eminently characteristic of the times, speaking, as plainly as words can speak, of heavy bottomless roads and slow progress. The unspeakable badness of the roads in former times may perhaps have been one reason for the fewness of carriages that were kept in comparison with what are kept in the present day, for formerly travelling was a real matter of slavish drudgery, and we are not surprised at our forefathers staying at home, or at our foremothers being able to spin, pickle, and preserve.

People who were past horse exercise had scarcely any alternative but staying at home, unless they tacked all the lumbering long-tailed cart-horses to the old family tub, and ploughed their way to the next town, furnishing subsequent lazy road-surveyors with the favourite argument against improvement, that "Squire Stick-in-the-mud's coach and four used to travel that road when it was far worse." Squire Stick-in-the-mud was never in a hurry, not sc Squire 
Stick-in-the-mud's grandson, who is always in a stew -always in motion and never doing anythingrailways have really made idle people believe that their time is valuable.

Housekeeping and riding we take it had been part of a woman's stock education in former days. If we consult the old novelists we shall find that quite as many heroines disappeared on side-saddles or on pillions, as in the more aspiring mode of hack chaises and four. Fielding, who had great knowledge of both town and country life, makes his Sophia Western arrive at the inn at Upton on horseback at night, attended solely, if we remember rightly, by Mrs. Honour, the housekeeper. We have not seen any writer attempt to subjugate a railway train, so as to invest it with the interest and sentiment necessary for a novel. The noise, the smoke, the hiss, the "now, marm, if you please; tickets, tickets, tickets, show your tickets"-the riotous bell, and alarm whistle, are all against the quiet privacy of an elopement.

Riding for ladies is now become wholly a matter of luxury-there are no journey ridings-even the pillions have disappeared with recent years, and farmers' wives drive to market in gigs with "Giles Jolter," or whatever their husband's name may be, painted up behind. When her Majesty took her daily promenades a cheval, as the French call them, in the Park, equestrianism was all the rage, and we had nothing but smart habits and slate-coloured veils. Indeed, each season shows a good muster of fair equestrians still, though, perhaps, not so many as there used to be. We never go into the Park without thinking how much better it must be for them than the enervating, listless motion of a carriage. Even park riding is slow work compared to the free gallop of the country, but to be sure park riding is generally pursued at a season of the year when it is too hot for hard exercise. 
One of the great faults of ladies' horses, and one that prevents a great number of ladies from riding, is having them too fresh-too much above themselves. Grooms have what, when properly directed, is a very laudable ambition, a desire to see their horses look well, and this they are very apt to promote by overfeeding and stimulants. High feeding, however, will not do for ladies' horses. They should be rather under than above themselves. Still you cannot get one groom in a dozen to believe this-at all events to act upon it. "Oh, mistress is going to ride to-morrow," and down goes another feed of corn. It would be much better to take one off and give the horse a gentle canter in the morning. When her Majesty rode, Miss Quentin always took the fiery edge off her steed in the riding school for her.

All sportsmen know that half the pleasure of hunting is in being pleasantly carried by a horse that you have perfect confidence in, and surely ladies must be equally sensible to the pleasures of comfort. There can be no enjoyment if you are constantly calculating when you are likely to be on your back. We do not know a more frightful sight than a woman run away with.

If low condition is desirable for the road, how much more so must it be if a lady enters the hunting field-a scene that is enough to excite the most sedate and orderly-minded horse.

And here we may observe that there is a wide difference between ladies hunting and ladies coming to see hounds throw off. They are as much in their place at the meet as they are out of it tearing across country. We like to see them at the meet; it shows that they take an interest in the amusements of their husbands, their brothers, or their sweethearts. The meet then being open to them, it follows as a matter of course that they should come on horseback. We cannot imagine poorer amusement than hunting on 
wheels - starving in a carriage on a cold winter's day, jolting about country roads, pitching from one side of the rehicle to the other, wondering which ditch they will go into. People in carriages seem out of their element altogether; they look as if they did not belong to the concern, and have very much the same sort of appearance that a man in top-boots and spurs would hare in a ball-room. Let ladies come on horseback, especially if they are pretty, for then the gentlemen can make up to them through their horses, just as they sometimes make up to gentlemen through the gentlemen's dogs. Moreover, having to "attend to the ladies" is an excellent excuse for any "coffeehouser" who wants to cut home when they find. Having then cantered to the meet, and seen old reynard start, let our fair friends canter home to luncheon, "with such appetites as they may"generally pretty good ones, we should think.

One of our objections to ladies hunting, though we do not know that we have ever seen it taken before, is that it deprives gentlemen of the agreeable change and variety which their society makes in the evening. Without intending the slightest disrespect to the fair sex, we may say that it is possible to have "too much of a good thing," and, if we exhaust all our jokes and small-talk in a morning, it is very likely we shall be "high and dry" in the evening. It is this sort of over-communication that makes daily hunt dinners such irksome, tedious things. You sit down with the same men that you have been riding about with all the day to a hash of the same conversation that you have been indulging in before. We have all our fancies and ideas as to what is most pleasant and agreeable, but to our mind the good dinner and cheerful female society of the evening is no small enhancer of the pleasures of the morning. If, then, the ladies have been at the meet, they can take part and interest in the hunting part of the conversation, 
which otherwise would be extremely dull and uninteresting to them. What man ever wants to be bored with the details of a day of which he has not partaken?

When women do ride they generally ride like the very devil. There is no medium with them. They either "go" to beat the men, or they don't "go" at all. We have seen some uncommon performers among women, performers that would put nine-tenths of the men to the blush. We are puzzled whether to give the palm to the single or to the married women in this respect; but, as the single are most interesting, perhaps the preference will be yielded to them. Like many things in this world it makes all the difference who the party is that hunts. If a pretty woman hunts we are all glad to see her; if an ugly one comes we wonder what "brings her out." Certainly disherelled hair, ruddy and perspiring face, and muddy habit, are more likely to be forgiven in the bloom of youth than in what ought to be the orderly sobriety of maturer years. We had dotted down a lot of names of first-rate female performers across country, but in looking it over we find it contains such a curious medley, that we think it better to suppress it altogether than risk the chance of offending by publishing an unpalatable assortment.

Never having been a woman, we cannot understand how it is they manage to keep their seats. We see what are called "wash ball" seated men rolling about constantly, and yet women, to whom the term as well as the form is much more applicable and becoming, manage to keep on. Keeping their seats on the road, and keeping them in the field are very different things, about as different as riding horses on the road and riding them with hounds. "Still, where there's a will there's a way," and pretty dears who would scream at the sight of a frog or a mouse, will face a bullfinch from which many men would turn away- 
indeed that is one of the palpable inconveniences of ladies hunting, for it is almost a point of honour for men to go over what ladies have taken. If it were not their ignorance when horses have done enough, and their great desire for pace, we would rather be a woman's horse than a man's. Women have much finer, and more delicate hands than men, and they never fight or bully their horses as men do-neither do they ever pull them into their leaps-by which means nine-tenths of the annual falls are procured. A horse worthy the name of a hunter would very seldom fall or make a mistake if left to himself. Let a man watch a loose horse, or even a raw foal, following the field, and see how safely, slowly, and easily, they go over places that some men and some horses terrify each other into believing are all but impracticable. Who has not seen horses throw arches, like the dome of St. Paul's, over places little wider than water furrows?

There was a neat little jaundiced backed book published a few years ago by Moxon, of Dover-street, called "Hints on Horsemanship to a Nephew and Niece, or Common Sense and Common Errors in Common Riding, by an officer of the Household Brigade of Cavalry," which, barring the officer authorship, always an objectionable paternity in our mind, gives a greenhorn as much instruction as it is possible to derive from books, and contains, besides sundry instructions about how to get on and how to get off, the following very sensible observations on the subject of pace- "I cannot finish," says he, "without one word to deprecate a piece of inhumanity, practised as much, perhaps more, by ladies than gentlemen-the riding the horse fast on hard ground " (our author might have included our old friends the Grooms, for whoever saw one that did not select the centre of the road, and how many do we see clattering along making up for lost time, seeming as though 
they were trying how soon they could wear the horse's legs out). "I pray them to consider," continues our author, "that horses do not die of old age, but are killed because they are crippled; and that he who cripples them is the cause of their death, not he who pulls the trigger. The practice is as unhorsemanlike as it is inhuman. It is true that money will replace the poor slaves as you use them up, and if the occasion requires it, they must, alas! be used up; but, in my opinion, nothing but a case of life and death can justify the deed. If the ground be hard and even, a collected canter may be allowed, but if hard and uneven, a moderate trot at most. One hour's gallop on such ground would do the soundest horse irremediable mischief. Those who boast of having gone such a distance in such a time, on the ground supposed, show ignorance or inhumanity. Such facts require cruelty only, not courage. Nay, they are performed most commonly by the very persons who are too cowardly or too unskilful to dare to trust their horse with his foot on the elastic turf, or to stand with him the chances of the hunting field; and such is the inconsistency of human nature, that they are performed by persons who would shudder at the bleeding flank of the race-horse! or who would lay down with disgust and some expression of maudlin, morbid humanity, the truly interesting narrative of that most intrepid and enduring of all gallopers, Sir Francis Head. But compare the cases. In the case of the race-horse, he has his skin wounded to urge him to a two or at most a five minutes' exertion, from which in ten minutes he is perfectly recovered and ready, nay eager to start again. In the case of the wild horse of the Pampas, he is urged for two, three, or perhaps five hours to the utmost distress for wind, as well as muscular fatigue; he is enlarged, and in three or four days he is precisely the same as if he had never been 
ridden. But in the case of this English road-rider, though no spur is used, unfair advantage is taken of the horse's impetuous freedom of nature; his sinews are strained, his joints permanently stiffened; he is deprived, at once and for ever, of his elasticity and action, and brought prematurely a cripple to the grave." Let the ladies remember that; it is not age that makes most horses useless, but work. It has been well said that a free-actioned, high-couraged horse will wear out two sets of legs, and we believe it. Let us then endeavour to make the one set that nature allows last as long as possible. Riding on soft ground will be found to be a great conducer to that end. Now to other matters.

If any pretty young lady were to propound to us the following-

"Do you think it would assist me in catching young Mr. Redrag if I were to take to foxhunting ?"

We should say :-

Be cautious; we have our doubts. It may catch him, or it may scare him. Some men think mounting themselves as much as they can manage, and would rather have a wife staying at home looking after the house than tearing about the country after the hounds. Besides, it is possible you might beat him, and men don't like being beat by their wives in the field, any more than wives like being beat by their husbands in the house. Again, we say, be cautious. But here comes a case in point: our fair friend, Henrietta Cottonwool. Henrietta has been after that weary Sir Rasper Smashgate, the whole of this blessed season, and now, as spring is about to set in, with its usual severity, she feels herself constrained to take some decided step. "To be, or not to be," is the point-Lady Smashgate or Henrietta Cottonwool. Henrietta is a fine, large, full-grown, healthy-looking girl, who, of course, says she thinks "all girls fools who marry," and yet at the same time would do 
anything to catch a husband herself. She uses the common figure of speech, in fact, or, rather, the common figure of lie-a figure so common, that if all men were married it might be abolished, for it only does for the bachelors, and those must be of the soft order, who believe it.

A man is not a match for a woman till he's married. That is an aphorism to which all Benedicts will assent. Our friend Sir Rasper Smashgate is in a somewhat similar predicament to the half-starved costermonger's horse, whose guardian boy declared had plenty of corn only he "hadn't got no time to eat it." Smashgate is matrimonially inclined, at all events he has no objection to matrimony, only hunting leaves him no time for making love. We should apologise to the baronet for not sooner sketching him, but the same sort of difficulty has attended our efforts - we never knew where we had him. Our reminiscent readers will perhaps recal that in the early part of these papers we mentioned the fact of Mr. Cottonwool having been partly converted to foxhunting, or rather fox-preserving, from having seen Henrietta in the grasp of Smashgate (waltzing, or attempting to waltz, as far as the Smasher was concerned), which, aided by the promptings of the ambitious Mrs. Wool, had induced our friend to have the Master and "Co." to feed (vide No. I of these papers). That man "Co.," as the country lad in London wrote to his father, "is a great man-he is in partnership with almost everybody;" but the Co. in this case was meant to include all the members of the hunt, or, perhaps, more correctly speaking, it was meant for Sir Rasper in particular and for the hunt in general. Sir Rasper was to be "Co." As the best laid plans, however, will occasionally miscarry, so, in this instance, Mrs. Cottonwool's project went awry. On the day of the dinner, which Sir Rasper accepted "conditionally," as indeed he accepts all his invita- 
tions during the winter, "if he gets home in time," he had gone eighteen miles "t'other way" to meet Lord Uncommonswell's magnificent hounds, which, never throwing off before eleven by their clocks, or halfpast eleven by other people's, had been close upon twelve before they moved from the meet, the Countess of Uncommonswell having come in her barouche and six, with five out-riders, to smile benignly on the field, and try to stick a couple of plainish sisters (now rendered still plainer by the addition of red noses), into any ambitious Nimrods who might aspire to wives out of a coronetted carriage. It was a show day, in short, and of course, late. The meet might be unusually protracted perhaps, from the circumstance of the countess not having any one in particular to whom she wished to recommend her goods, she had, therefore, to keep a stall, as it were, and trust to chance for customers. Some men think of nothing but sweet-hearting. They are always "dying" for some girl, and commit as many imaginary demises in the twelvemonth as old Mantalini himself.

When the hounds did throw off in earnest (for of course they had to draw two or three sham places first, for the accommodation of the ladies), the way they dashed into Everhold Gorse plainly said that sly-boots (if he will allow us to call him so) was at home, and before Lord Uncommonswell had got half through his dog-language, a great banging big-brushed, white-tagged, greyish-backed dog-fox, almost knocked the fifth Whipper-in off his hind legs, as he was trying to open the bridle-gate at the north end of the cover. The poor lad was so paralyzed-never having been in such close contact with so formidable a customer - that a second or two elapsed ere it occurred to him that he ought to do something, a pause that master reynard availed himself of for stealing quietly up the deep newly-cleaned-out ditch of a thick hedgerow. At last the lad having climbed 
on to his gigantic horse, hoisted his cap in the air, which had much the effect of the prolonged flourish of the head-fiddler at the opera.

A terrible noise was the result!

"Now," as Peter Beckford familiarly asks, "where are all your sorrows, and your cares, ye gloomy souls? Or where your pains and aches, ye complaining ones? One halloo has dispelled them all."

Peter's description does not exactly fit our hunt, for we had a hundred halloos at least, and half as many screeches and yells, to say nothing of the discordant brass music of the noble Master and his Huntsman.

However, the following will do:-

"What a crash they make, and echo seemingly takes pleasure to repeat the sound. The astonished traveller forsakes his road, lured by its melody; the listening plowman now stops his plow (sic in the original, as the lawyers say), and every distant shepherd neglects his flock, and runs to see him break. What joy! what eagerness in every face!"

And then Peter prigs a bit of poetry from Somerville, which we in our turn will prig from Peter, requesting the accommodating reader to turn the sentiment about the forgetfulness of sorrow into Smashgate's total forgetfulness of Cottonwool's dinner :-

"How happy art thou man when thou'rt no more Thyself! When all the pangs that grind thy soul, In rapture and in sweet oblivion lost, Yield a short interval and ease from pain!"

We like old Somerville for that idea; it speaks the sportsman. Sporting writing has this charm, it is sure to tell with sportsmen. Others may turn up their noses (some people's noses seem only made for turning up), and say "what stuff!" but good sporting feeling is sure to tell where it is intended. Who has 
not felt one tally-ho! banish old dull care, for as every Frenchman has a "suit," so every Englishman has a sorrow, and it is only by increasing their size that we are sensible of the smallness and absurdity of the old ones. It has been well said that an Englishman is only thoroughly happy when he is miserable.

Be that as it may, however, Sir Rasper Smashgate had as few cares as most people. His hopes and fears were centred in his stud, with the addition, perhaps, of his razors. If he got a good shave in the morning he was generally happy for the rest of the day, for he had twelve as good hunters as a sixteen stone man could desire, with two thorough-bred hacks, and a stud-groom equal to his business, and yet not above it. Added to this, Sir Rasper was in the heighday of youth, stood six feet high in his stocking-feet, with a great deal of good land, and a great deal of money in the funds - two most desirable concomitants-moreover, he never laid out a shilling in pills.

Smasher (for so he is called by his friends) came to his title from an uncle, at an earlier period than uncles are generally in the habit of putting off their shoes, before which our hero had lived at home with his mother, who had long held a commission to get him a wife-a commission that we regret to say she had departed this life without executing. Smashgate was an exemplification of the good and dutiful son, for he was ready to marry any one his mother recommended; but thinking she would be the best judge of the article, he just left it to her to suit him, as he would the choice of a piece of linen for shirts, or as he left it to Tilbury to supply him with horses. Somehow Sir Rasper was never much in society, though many great ladies had him high on their list of "eligibles," and some had gone to no little trouble in "touting " him. Whether his mother had put him 
up to a thing or two, or he had too manly a mind to contend with the lisping butterfly things he had to encounter we know not, but certainly, after the death of his mother, Sir Rasper seemed more likely to be a bachelor than a Benedict.

Wie sometimes meet men like Sir Rasper Smashgate in the world-men who seem neglected by the sex, just as we see women neglected by the men. Indeed, there must be many such, for it was only this morning we encountered the following amusing advertisement in a Sunday paper :

"MATRimovial Societr.-Single ladies and gentlemen really desirous of entering that state which heaven has adjudged to be the most conducive to virtue and happiness, will find the above truly deserving of their consideration and confidence. A select party of ladies and gentlemen, combining rank, influence, characier, talent, and extensive acquaintance, influenced principally by a desire to extend the social comforts they have realised to the hermits around them, whose single state is the result alme, perhaps, of circumstances, hare determined to improve their leisure by promoting, as it lies in their power to do, felicitous unions. To prevent imposition, a trifling sum is required as a proof of sincerity, and nothing afterwards, but on the realisation of matrimonial bliss. Both parties mutually bound to secrecy and sincerity.-None but respectable characters need apply; who will be treated with the utmost respect and decency:"

The prevention of imposition is a charming feature in the foregoing. It is like the livery stable notice, "for fear of accidents, pay before mounting." Sir Rasper Smashgate had never been reduced to this deplorable state, but the death of his mother, and hearing nothing about matrimony, coupled with his extensive prosecution of the chase in winter, and the attractions of Epsom, Ascot, Limmer's door, club windows, and yachts in summer, with shooting in autumn, drew him more and more from the petticoats, till at last disappointed mammas used to speak of him as that "orrid man, Sir Rasper Smashgate," and indulge in the usual insinuation ladies deal in against 
men who don't make up to their daughters-" Poor lost creature!" and so on.

We have now run a ring with our hero, and shall bring him back to the starting place to see if Henrietta Cottonwool can run a "ring" with him too. Oh, could but another Diable Boiteux visit the earth, disclosing the secrets of human breasts, as Le Sage's Diable disclosed the secrets of the town, what a real blessing it would be to sighing, dying, suitoring lovers! When Sir Rasper Smashgate did not cast up at Cottonwool's, what tormenting thoughts racked the mind of poor Henrietta! Dressed in her new pale blue satin, with a point berthe, and a silver thing like a cow tie twisted in her bright brown hair, and a winter's nosegay in her hand, of which nosegay she was ready to give Sir Rasper any part he asked, or the whole of her hand if he preferred. All this, too, after she had planned the proceedings of the drawing-room, the line of march to the dining-room, so as to manœuvre herself next him at dinner, ring after ring, and door after door opened, and no Sir Rasper. Everybody but him.

Cruel Lord Uncommonswell! or rather cruel fox that took the cruel hounds such a cruel distance. When Sir Rasper Smashgate ought to have been sitting down to dinner at Mr. Cottonwool's, he was sucking off a pair of waterlogged boots and tripey leathers at a village public twenty miles off. They had had a tremendous run! They were sure to have, indeed. It only requires a man to have a particular engagement in the east to insure him a splitting run to the west. Sir Rasper had been uncommonly well carried; indeed, he generally was, and wearing a blank button had felt himself bound to ride for the honour of the world at large. $\mathrm{He}$ was so elevated that we are almost ashamed to say he never thought of Cottonwool, Henrietta, or anybody, until he got his huge legs dived into a bucket of hot water. 
Then, as he sat thinking the run over, and debating whether he should have "beef-steak," or "muttonchop "- "mutton-chop" or "beef-steak," for dinner, it occurred to him that he ought to be dining at Cottonwool's.

"Ah, well, never mind," observed he, "I said I'd come if I could," and, with that easy indifference, he settled both hopes and fears, and the fate of all the roasts, boils, jellys, and creams. Much as women may pretend to like hunting, there is not one old one in a hundred who will admit the excuse of a "late day" for a non-appearance at dinner, at least at a "spread." Dinner, in their minds, is the grand business of life, it takes precedence of everything. "Men have no business to accept invitations, if they ain't sure they can come. All stuff about the hounds - mere excuse-Mr. Spoonbill and Mr. Slowman could both come away-why couldn't Sir Raspercould, if he would-where there's a will there's a way ; "and then they generally wind up with the old assertion, that "he'll come the next time he's asked," meaning that they won't give him another chance, which most likely they don't do until it suits their convenience, when, like Lord Byron's lady, who "Loves again,

To be again undone,"

they invite again, to be disappointed a second time.

Gentlemen, however, may take our word for it, it is no use joking with the ancients about dinner. We have reason to believe that we lost a very stiff legacy from a sturdy old aunt, whom nothing could convince that we were not humbugging about the hounds. We had promised to dine with her to meet old Sir Timothy Grumpington of Grumpington Hall, Gray's Inn-road (a sweet rus in urbe on the left, as you go north), and unfortunately our friend Joseph Lob of Highbury-terrace, offered us a mount with Lord 
Derby's staggers (for it is long ago, and aunt, Lord Derby, Grumpington, staggers and all, have long been in their graves), which met at the White Lion, Lock's Bottom, whither Lob offered to drive us, and bring us back if we liked. The great merit of staggers undoubtedly is the certainty of a gallop, and the pretty near certainty where you will finish; but, on this provoking day, the insensate creature seemed to have had a turn for visiting every part of the country ; and north, south, east, and west, were equally faroured with his presence; the consequence of which was, our aunt was not favoured with ours for threequarters of an hour after the appointed time, when we found Sir Timothy Grumpington with half-appeased appetite, but wholly unappeased mind, and aunt in that direful state of excitement that old ladies invariably are whose whole dinner has been spoiled by long waiting. People should be all in the same boat who sit down to a long-delayed dinner.

But let us hark back to Henrietta, Sir Rasper, and Fleecy Hall, for we want to get a glance at the end of the season before we finish our book. Sir Rasper, as we said before, did not cast up at the Fleecy Hall dinner, and, as usual, in all cases of extreme anxiety, no end of mistaken, and, we fear, somewhat illiberal surmises, were indulged in, as to the cause of his absence. Mrs. Cottonwool, who had been "trotted out" by a few men before she became Mrs. Cottonwool, and knew all the symptoms of "no go," set it down at once as a case of desertion-" trifling with her daughter's feelings," as they call it. It never entered her mind that a man could love hunting better than his food, after the fashion of Gray's bulldog, who is reported to have loved fighting better than his, and therefore she would advise Henrietta to have no more to say to Sir Rasper. Indeed, for her part, she thought her daughter had had a most fortunate escape, for it was quite impossible to look 
for conjugal happiness with a man so thoroughly undomesticated as he was, who thought of nothing but tearing about the country from morning to night; indeed, if all were true, there were other objections, which Mrs. Cottonwool indicated by sundry little tosses of her head, much in the manner of a carriage horse teazed by flies.

Old "Wool," of course, said that he never thought there was anything in it, which procured him the usual recommendation "to hold his tongue, and not talk about things he did not understand," for Mrs. Cottonwool had clearly settled in her own mind that there had been a "nibble," and though she might pretend to "whip off" at present, she meant to lay Henrietta on again the first convenient opportunity. Those opportunities in the country are very rare, especially in the hunting season, where men will make their engagements subservient to hunting. This is where hunt balls tell; it gives the women a chance of bringing men to book; for, as they cannot be hunting at night, if they have any "real intentions" they can come to a ball.

Henrietta Cottonwool, of course, being of the same way of thinking as "mamma"-indeed, mamma's opinions must have been chiefly derived from the daughter-has determined not to let the season close without a final effort for our hero. Accordingly she has enlisted one of those convenient articles called a cousin, that women know so well how to use, either as suitors or cats'-paws, to attend her to the meet. Well she looks as she sits on her horse, and if the animal was only as well turned out as she is, she would do uncommonly well. There is not one woman in a hundred with the slightest idea about either a horse or a carriage. Thin legs and long tails are all they look for in a saddle-horse. Small legs, however, would not exactly do for Henrietta, for she is a good load, though her well-formed back and 
waist are admirably developed by the close-fitting evenness of her well-made London habit. The hat, too, becomes her. It rather fines than fulls her plump healthy cheeks, and the maid has given some extra labour in the brightening and arrangement of her flat-dressed hair. Most young women look well in hats and habits. But here comes Sir Rasper, bearing down the road like a man-of-war in full sail. He comes at the pace of the regular five or six days a week man, who knows to a minute how long it will take him to "do" each meet. You can tell at a glance that he is a workman; every thing bespeaks it, from the hat on his head to the spur at his heel. What an age of anxiety-what a world of time is often comprised in a brief, unpremeditated moment like the present! A glance, a look, a word, and the thing is done. Sir Rasper greets our fair friend with the hearty cordiality of a half-way-met agreeablysurprised foxhunter. $\mathrm{He}$ is pleased with the attention of so fine a girl. A tinge of pink pervades Henrietta's bright healthy complexion, as she recognizes the pressure of his somewhat hard hand. When hers is released she dives into the saddlepocket for the fine lace-fringed handkerchief. Cousin Spooney looks amazed.

How long soever a man may be about it, it is clear there must be a first thought, a first impulse as to marrying a girl, and Sir Rasper's impulse came on him rather suddenly this morning. Pleased with Henrietta's appearance, flattered by her preference, and perhaps wanting a solace for the fast wearing-out season, he said to himself as he changed his hack for his hunter, "By Jove, why shouldn't I marry her?"

TO OUR READERS.

"If any of you know cause or just impediment why these two persons should not be joined to- 
gether in holy matrimony, you are now to declare it."

\section{ORDERED,}

"That she be made, Lady Smashgate accordingly ; and that we have two pair of gloves and one pound of cake sent us. Cards and compliments we dispense with."

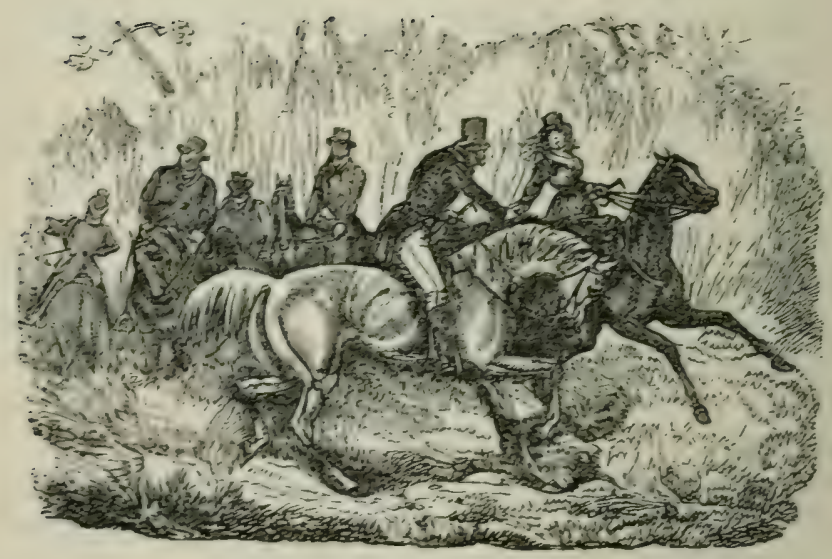




\section{CHAPTER XXI}

COLONEL CODSHEAD; OR, THE CLOSE OF THE SEASON

"I knows no more melancholic ceremony than takin the string out of one's at, and foldin hup the old red rag at the end 0 : the season-a rag unlike all other rags, the dearer and more hinterestin the older and more worthless it becomes."

JORROCK'S SPORTIN LECTOR.

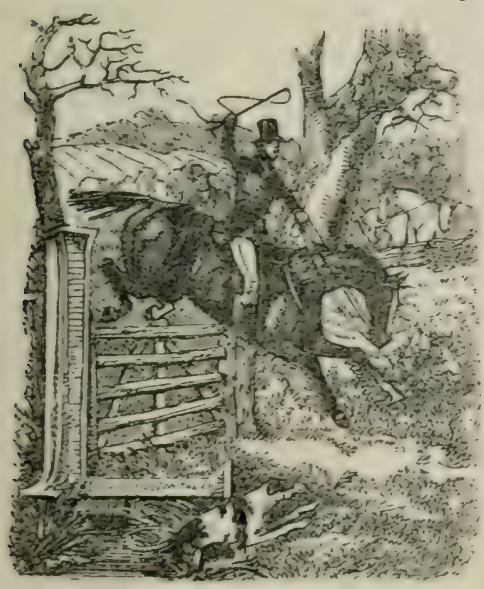

ORD bless us! here comes old Colonel Codshead-old we may well call him, for we have seen him cast up at the end of fifteen seasons, vowing each time that he meant to take to hunting in "right earnest" at the beginning of the next. Season after season have we seen the incursions of good living on his frame, marked the slow progress of corpulence, as layer after layer of fat has been added to his size. Fourteen years ago, the colonel, though not slim, was what might be called a fine stout healthy looking man-full limbed, but not obese-ruddy, without being pimply, blotchy, or purply.

Now he looks like an over-fed alderman. His 
lascivious eyes are starting out of his head, the roses of his flabby cheeks have dissolved into numberless little red veins, while his mulberry-coloured nose has thrown out divers little knots and hillocks, all indicative of devotion to the jolly god.

Codshead has on the very coat-nay, we believe, the very coat, waistcoat, breeches, and boots-in which he appeared fourteen years ago. The coat, we remember, was the first dress one-the first

"Bed by night, and chest of drawers by day,"

that appeared in our country, and of course produced a corresponding impression. It then fitted him as a coat should fit, easy and comfortable-looking, neither too tight nor too loose; the waist was where the colonel's waist was, and if the collar was twice or thrice the breadth of collars of the present day, it was not a bit more ridiculous than the hem-like things of our times will be hereafter. It was then a fresh, wellfavoured coat, and though we cannot say we admire the cut, it nevertheless became the colonel. Alas! how changed are both coat and colonel!

There is nothing hurts a man's vanity so much as the conviction that he is getting fat. So long as he retains his figure and activity he may be any age, but when this

\section{"__ too, too solid flesh won't melt,"}

when relentless beef will load the neck, back, reins, loins-all the places that used to be mentioned in Moore's once indelicate almanack-a dreadful conviction comes over him, that-to put it in the mildest form- he is not so young as he was.

Against this terrible admission Colonel Codshead has long borne up stoutly and manfully.-He will not admit that he is an ounce heavier than he was twenty years ago, and all because by dint of extreme exertion 
and compression he can manage to squeeze himself into the clothes he wore then. It certainly says much for the elasticity and the accommodating nature of human raiment that the clothes which then encased our hero, will now contain a carcass almost half as big again. Pride feels no pain, they say, and that is lucky, or our colonel would be in the height of suffering at the present moment, for the once easy, well-fitting coat is now as tight as the parchment on a drumhead-indeed all his clothes are in a corresponding state of uneasiness.

The coat is one of the few instances we have met with of a scarlet coat being absolutely shabby without bearing any apparent marks of wear. A hunting coat generally fails at the laps, which acquire a fine buckram-like feel and plum-coloured hue, to the enhancement of the rest of the garment. The Colonel's coat has gone down altogether. It has no more sign of wear-horse wear at least-than an omnibus cad's, or an old Vauxhall waiter's. There is something healthy, sporting, and pleasing in the sight of a well-dyed, well-stained, dull-buttoned old coat. We look at it with the sort of reverence that we regard the tattered banners in a church chancel, or in a baronial hall. We respect the old rag for what it has done; but a frowsy, dusty, faded, flannelly, bathbricky looking thing like the Colonel's, suggests a finger and thumb to the nose more than anything else; yet it has seen service-drawing-room, diningroom, ball-room service, but little-very little-outof-door work.

The history of a hunting coat, from the matter-ofcourse fall on the first launch, down to the ultimate dismissal as "too bad even for a wet day," would furnish a fine theme for the pen of the biographer of the "fox," or any other gentleman short of a subject. The Colonel's coat, we don't think, ever got the initiatory fall; it has been an upstanding one all its 
life. Some men pass with the ladies for great sportsmen because they never get falls; the dear creatures never imagining for a moment that they never get them because they never give their horses a chance of giving them them. So, again some ladies, when they hear of Captain Fearnought or Mr. Daredevil getting two or three tumbles a-day, immediately set them down as desperate tailors, imagining, of course, that they tumble off. To adapt the doctrine of hunting mischances to the "meanest capacity," the horses should be described as getting the falls and not the men. But let us paint away at the Colonel, for he covers a great breadth of canvas.

The most forlorn looking things in a hunting field are a pair of old tight moleskin breeches, bursting at the knees. How Colonel Codshead ever got his great uncompromising legs wheedled into his, passes our comprehension. Were it not for the danger that would attend the performance in consequence of the frailty of the article, we should imagine that he had had recourse to the old expedient of being slung into them, as it is said the booted dandies of George the Third's time used to be into theirs, when an exquisite giving an order to his leather breeches maker added these emphatic words, "Mind, if I can get into them I won't have them." Colonel Codshead's moleskins have seen many seasons-they are far anterior to the coat-indeed we remember thinking, when it was launched, that it would have been as well if he had carried his attentions a little lower, and got himself a pair of new breeches also. Since then the buttonholes have been acting the part of a boy's nick-stick prior to the holidays. Each succeeding season has scored a rent until there is not a button-hole without a darn. The whole ten buttons look as if they were ready to fly off at a moment's notice. Tremendous work it must have been getting them coaxed together! The boots are quite of a piece with the breeches, with 
whom, however, they do not seem on visiting terms; a great interregnum-supplied certainly with a protuberance of most puddingey calf-intervening between them and the moleskins. Spurs he doesn't sportthey might be dangerous.

Colonel Codshead's anonymous-coloured, collarmarked horse, is of a piece with his master-a great plethoric, overfed creature, incapable of exertion if his rider wished it. Indeed the evenness of condition of the two is the only point we can praise ; and certainly it is much more sensible for men to regulate their horse's strength to their own, than to strive for that tip-top condition, the property and prerogative of stout nerves. What is the use of having a horse equal to double the exertion the rider is capable of? The Colonel's horse, in the palmy days of machiners, would always have commanded forty pounds, for he has size and strength enough for a wheeler; indeed we do not know but he might fetch forty pounds now, prices being somewhat up. $\mathrm{He}$ is a dull, inanimate, heavy-countenanced, ugly-looking animal, rendered still worse from having been badly clipped, and being now in that state of transition so trying to all horses, the half-way house between his two coats. A badly clipped horse looks wretched on a frosty, or cold, drying day.

There is something about hunters-indeed about horses that have any pretensions to that characterthat shows itself before you come to the real hedging and ditching work. The horse that evinces no increased pleasure or activity of action on changing from hard ground to grass, has seldom any seeds of the chase in his composition. His forte is harness. The horse that puts his feet into ruts, grips, and water furrows, instead of hitching himself over them as it were, will be very apt to do the same in the field, and it is perfectly notorious that a man may break his neck at a small place as well as at a large 
one. Indeed, we believe, if the catalogue of accidents was canvassed, it would be found that the majority of them have happened at small places. Horses either do not see them or will not give themselves the trouble to clear them. Hence men who hunt in parts of Essex, and other widely-ditched countries, declare that their formidable-looking leaps are the safest-a comfortable theory to those who can bring themselves to believe it.

Codshead is always "wanting a horse." There are a good many men of this sort in the world, men who are always on the look out, but who never buy. In introducing Captain Shabbyhounde to our readers in a former chapter, we commented upon the "I'll sell you a horse" figure of speech sometimes adopted by young men, or would-be great sportsmen, and knowing ones, and the "Do you know of a horse that will suit me?" is the corresponding figure of speech for the other end of life-adopted either by desperately cautious men, or men who just ask the question because they think it is fine to ask about a horse, or from want of something to say. It seems an absurd sort of question-for how are we to know what will suit another man. Half the people in this world don't know what will suit themselves. A quick tailor or bootmaker, they say, will measure a man with his eye, and perhaps a horse-dealer may have the same knack at guessing what will suit a customer; but the generality of people who are bored with the "do you know of a horse that will suit me?" question have no such ability. To be sure, if one sees a great pudding-headed, snuffy-nosed, wabbling-gutted fellow stumping about, we may say "that man's only fit for a cob, or for water carriage;" but the bulk of horsewanters have no particularising mark, no characteristic, or indicating symptoms. It is only in the hunting field that riders can be classed. There one can say, such and such a horse will suit such 
and such a man; because we see what both can do, as well as what both "can't do," or won't try to do.

If you were to shpw Colonel Codshead a hundred and fifty horses he would pick a hole in each. Indeed people are tired of showing him them, and to say that you know a man who wants a horse, and name Colonel Codshead, is enough to provoke a smile on the face of the owner. Young Tom Rapid, who is always in a hurry, having nothing whatever to do, always greets our hero with, "Well, Cod, how are you ?" adding, in the same breath, "I don't knowe of a horse that will suit you."

But hark! our Master greets the Colonel. Let us hear what passes. Ten to one but it is the old story.

Master, loquitur. "Good morning, Colonel Codshead ; glad to see you among us at last."

"Good morning, sir," replies Codshead; "glad to find myself out, I assure you; quite refreshing after the toils and fatigues of office."

Master. "Oh, ah, I forgot; I've the honour of addressing the Mayor of Turtleton (Master raising his hat as he speaks), I hope we shall see more of you; though the season, I am sorry to say, is about over."

"More's the pity," replies Codshead; "I was in hopes to have had some good spring hunting."

"Not this season, I'm afraid," replies the Master; "too dry-fallows flying-farmers making up their fences."

Codshead. "Well, better luck next time: must begin early next year."

"Do," replies the Master.

"Buy three or four good horses, and hunt regularly," rejoins Codshead.

"That's your sort!" replies the Master.

"Never feel so well as I do after a good day's 
hunting," adds Codshead, bumping himself in the saddle.

"Fine healthy amusement," observes our Master.

"You don't know of a horse that will suit one, do you?" asks Codshead-(hurrah! we knew it would come).

"Not at present," replies our Master, with a smile, having had an inward wager himself as to whether Codshead would ask the question or not.

There are many Codsheads in the world-many men who fancy they would like hunting amazingly when they can't get it, and who never trouble it when it is to be had. Scarlet coats have a rast of lies to answer for. The Colonel, like his horse, has not the slightest natural inclination for hunting-indeed, it is rather a punishment to him than otherwise-he hunts for the sake of the society and the good dinners it procures him. After that, we need scarcely say the Colonel is a bachelor. Now, a married colonel, and a bachelor colonel, though born in the same year perhaps, are very different aged people in female estimation; and our Colonel-albeit, but a yeomanry one-ranks rather as one of those pretty boyish colonels peculiar to the "Guards," than one of the hobbling, frosty-pated, wound-scarred old cocks of the Peninsula or Waterloo.

A woman's foxhunter and a man's foxhunter are very different things. If a man in a red coat is always at a woman's beck and call-always ready with something to say (a feat, by the way, not in the accomplishment of all)-alway's ready to dance attendance at their carriage sides when they go to see the hounds throw off-always careless of the hounds for the sake of their company-they think him a most agreeable, engaging, captivating man-just what a foxhunter ought to be, and when the "pasteboards" go out such a man is sure to be remembered.

The man's foxhunter is one who adores the ladies, 
delights in their society, would ride a hundred miles in the wet to serve them (on a non-hunting day), but from the greatest beauty of whom the joyous Tally ho f would draw him like a shot. Women like deeds of daring, and the man who would leap turnpike gates, garden walls, spiked palisades, and such-like trifles, would find favour in their eyes for the madness, while the sportsman would set such a performer down for a fool.

We need not say that Codshead is a woman's foxhunter, any more than that he is not a likely bird to attempt any eccentricities in the leaping way. He gets out of that scrape by professing to be one of the "has beens"- " used to be a desperate rider-would leap almost anything." $\mathrm{He}$ is only a "has been " in the riding way though ; in other respects he looks upon himself as the pink of perfection, and truly it says little for a neighbourhood where such a slushbucket is tolerated.

Yet he is not only tolerated, but run after. His red coat far oftener appears above a pair of black shorts than above the darned moleskins, while the glorious amplitude of calf now bagging over the too tight top, like an overgrown omelette souffé over a small dish, procures for him the appellation of a "monstrous fine man." Somebody once told him that he was like George the Fourth, and he has dressed the character ever since-puffy, clean share all round, with a profusion of wiggy-looking curls at the side of his broad-banded, broad-bound, broadbrimmed hat. We wonder how many Princes and George the Fourths we have seen in the course of our time?

Codshead is in request among the women, who have a very favourite maxim, "that a man is never too old to marry." Comfortable assurance!

To be sure Codshead's age varies a good deal, according to the views and prospects of the speaker. 
A mamma, with a "fairish chance" daughter will kindly put him down at forty, while another with small, or diminished hopes, will run him up to sixty. Still, if there is a dinner going on within ten miles of Turtleton, Codshead is sure of an invite. Single men are always in request, even though they are as big as-

"Two single gentlemen rolled into one."

This year he has shone forth in redoubled splendour - Mayor of 'Turtleton, as well as Colonel Codshead, and the consequent good living is visible alike on his carcase and on his countenance. His hunting serves to bring him in dinners. Very few appearances in a red coat procure a man the reputation of a foxhunter among the non-hunting portion of the community, and the politeness of a well-judging world always associates good society with the sport. Thus then, if Mr. Closefist objects to having our Colonel invited to dinner, insisting that he is nothing but a great overgrown sponge, Mrs. Closefist will retaliate that he is a man in the very first society, a man who visits everybody, a great man with the Scourcountry hounds, and Codshead comes, if in the hunting season, of course in his red coat. Women and mackerel are all for scarlet.

But what a place Turtleton must be when Codshead is its great authority on hunting. He is the Nimrod of the place. Somehow burgesses are seldom built for boots or saddles. They sit their horses, as they do their stools, with firmness, ease and grace-until they begin to move, and then it's all up with them or rather all down. Colonel Codshead returns thanks for the toast, "Success to foxhunting," far oftener than he puts the success of it to the proof. $\mathrm{He}$ is a slow, pompous, broken-winded speaker-he looks like one. "Gentlemen," says he, for it is the same thing over and over again; "gentlemen," says he, looking 
especial wise, "I beg to return you my best (gasp) thanks for the (gasp) honour you have done me in drinking my (gasp) health in connection with foxhunting (gasp). Gentlemen, it is a (gasp) sport, gentlemen (gasp), peculiar to (gasp) Britons, and dignified (gasp) with the (gasp) of the greatest (gasp) men of the (gasp) day [applause]. I hope (gasp) I shall never live (gasp) to see the (gasp) day when it will be (gasp) other than (gasp) popular. It brings the (gasp) peer in connection with the (gasp) peasant, and bind all its (gasp) followers up in social (gasp) harmony."

But let us dismiss the great puffy porpoise, and talk about something else. He will soon dismiss himself if they find a fox. This day, however, is to qualify him to talk of hunting for the summer. Alack-a-day! talking of it will be the most any of us can do for some time. However, never mind, we have had a glorious season-wonderful and curious in weather, and certainly more than an average one in point of sport. We hope our readers have laid in a good stock of consolation for its close, by having made the most of it while it lasted. Cub hunting was late, owing to the harvest; indeed, in some countries they would scarcely have any; but when hunting did begin we had a rare and continuous run of it. Hounds could never be said to be fairly stopped, till just as many were thinking of stopping themselves towards the latter end of March, for, though there were occasional checks in particular districts, yet, as a whole, they were never brought to a stand-still, as they are in decided frosts or regular snow-storms. The weather was various - in most parts fine, in many unseasonably so.

At Chiswick the meteorological register kept at the gardens of the Horticultural Society gave a state of weather unprecedented for many years in December and January, in which latter month Covent-garden 
exhibited quite a spring-like appearance-primroses, violets (sweet-scented), cowslips, anemones, and many of the flowers which in mild seasons usually bloom in the month of February being seen in profusion. The fine weather extended throughout the country.

The northern papers of the end of January spoke of the mildness of the atmosphere producing a premature effect on vegetation, and said that the thrushes were warbling forth their "wood notes wild" to welcome the return of spring, and altogether it was a most unusually open season.

The absence of frost was one of its striking characteristics, and with the absence of frost may be noticed the almost total absence of accidents. ITe never remember a season with so few-no necks, no limbs, scarcely a collar-bone broken. This shows that hunting is not a dangerous amusement if people will only follow it rationally. It makes all the difference in the world whether a man falls on the flags or on a feather bed. It is of no use contending with the adverse elements, nor is there any pleasure in trying to force a season unnaturally into the spring. That man is the best sportsman who knows when to leave off. But to the close of the season, for we are no advocates for the family slaughtering of "Mayfoxes."

Winter slipped away beautifully, to the delight of foxhunters and the Wenham Lake Ice Company, and the dismay of "native industry" among the confectioners and salmon picklers. But for the "woodcocks," peculiar to Christmas, we should never have known it had been here. We are not unreasonable in our desires, and if we get the year fairly hunted out, and a few days for the boys at Christmas, we never grumble at a fortnight's frost or so; but this year the weather was kinder than we even desiredJanuary was open from end to end-whole thirty-one days - a bumper month. There might be a sprinkling 
of snow here and there, and a night or two's frost, but as a whole, hounds were never stopped. February we have recorded. The early part of the last week of that month was as full of warmth and vegetation as many ordinary Mays or Junes. The trees were all budding, the hedges were all bursting into leaf, and gentlemen rode up to their horses' girths in turnip-tops.

Our "oldest inhabitant"-for all discreet authors keep an oldest inhabitant of their own-our oldest inhabitant always shook his head, however, when he looked in upon us, and we observed upon the extraordinary fineness of the season, and the fact of winter having forgotten us. "Don't halloo, before you are clear of the wood," the old gentleman used to say, for he was a hunter in his youth, though when that youth was nobody knows. "You'll catch it yet," he used to say, in the oracular style peculiar to old gentlemen, speaking what they think parables.

Well, we will let him have his fling through January, for we thought it likely we should "catch it," and we backed him well into February too, but when the birds began to sing and Covent-garden to blow, why we thought it was time to follow the fashion, and throw "previous opinions" to the winds; so the next time the old cock called, we began to crow over him. "Well, where's winter?" said we; "where's all the bad weather you promised us?" "Young man," replied he, gravely (we are only sixty-three), "young man," replied he, knitting his shaggy, snow-white brows, "I have lived a long time in the world, and I never knew Death, the Tax-gatherer, or an English winter forget to come. I don't mean to say," continued he, "that we shall have it all in the Me-tropo-lis, but I mean to say that winter is not over yet." With that he resumed his cocked hat and cane, and went across the water to the other "undying one," at Astley's. 
Old gentlemen don't like to be laughed at young ones neither, sometimes-and we saw no more of our "oldest inhabitant" till the middle of March. The season in the meantime had been quiescent, no great advance in vegetation, but no check to what had arrived. As the "old 'un" had rather inconvenienced us by his absence, having had some questions put about events that occurred shortly before the great fire of London, a scene at which he was particularly active, we did not think it prudent to broach the subject of the truant winter, and the "oldest inhabitant" having got through the arrear of antiquarian questions, took his departure in the hurried way people do when there's a disagreeable topic they don't want mentioned.

Hunting, we reckoned, was fast winding up. March has never much ingratiated itself with us as a hunting month. It sounds harsh and repulsive, speaks rather of high winds, hard dusty roads, and flying fallows, than of that delightful, sloppy, spongy, splash-myboots state of things peculiar to the legitimate chase.

Third week in March, and spring slowly, though steadily on the advance. This "oldest inhabitant" is getting "too old," thought we, for he had looked in at our publisher's, on Saturday, (the I 4th), and reiterated his conviction that we should catch it yet.

"We really believe we may have too old an oldest inhabitant," continued we, thrusting our hands, $\dot{a}$ la D'Israeli, into our breeches pockets, and pacing about our apartment. If we knew where to lay hands on one from a hundred to a hundred and fifty years old, we really think we would "shelf" this oldest inhabitant, for he is evidently getting in arrear of the times.

A change then came o'er the spirit of our dream.

All our northern and midland letters of the $\mathrm{I} S$ th of March, spoke of the withering influence of the pre- 
ceding day. They said the weather was cutting cold, with every appearance of a fall. When people talk of a fall, in relation to the weather, it always means "snow"-rain they designate by its proper title. We would not have met our "oldest inhabitant" that day for something. Not that the old man would have exulted over us, for Widdicombe and he are far removed above the scornful passions and prejudices of the world; but our own conscience would have upbraided us for doubting the accuracy of the ancient. Straightway we went to the leather-breeched ancient on Snow-hill, and bought our "oldest inhabitant" half a hundred weight of fleecy hosiery. Nor was the present unseasonable, for the Scotch, northern, and midland papers of that week's end brought up direful accounts of hurricanes, tempests, and tremendous snow-storms, accompanied by nipping frosts. At Newcastle-upon-Tyne, where the civilization of railways shoots across the island to Carlisle, the blackfaced ones were uncommonly well powdered. It appears by the prints of that region, that her Majesty's mail-bags are conveyed onward to "Auld Reekie" by means of coaches and horses, and they talked of six horses being necessary on parts of the road. Such doings sound queer in our railway-netted world. However, the storm came, and though we escaped in "Me-tro-po-lis," as our ancient calls it, there was plenty of it in the country, and it was cold enough in town. So the prophecy of the ancient was fulfilled, and he has risen in our estimation in consequence. Never will we believe flowers, thrushes, lambs, or anything of the sort again, in preference to our own "oldest inhabitant." What with the hosiery and this notice, we trust our friend will think we have made the amende honorable.

A snow-storm is a punishing thing; it puts a stop to everything. As we said before, we can stand it at Christmas, but at no other time. At Christmas we 
can console ourselves with the thoughts that it is seasonable-that as we must have it, it is better to have it at the right time, and be done with it - that the horses want rest, and we draw our chairs round the fire, and look forward to resuming the field with redoubled zeal.

But a March storm, while it checks hunting and blights all our floricultural hopes and expectations, presents no bright prospect in view. Go when it will, hunting, we feel, cannot return, at least not in the genuine, natural, other half of the thing, sort of way.

The only consolation about a March storm-at least one late on in the month-is that they never last. They are like frosts in November, which are sometimes uncommonly keen and iron-bound at night, and yet extremely wet and sloppy in the morning. When a March storm gets the turn of its complaint, it generally subsides very fast. A day of cold, bitter, blustering storm will be succeeded by one of balmy sunshine, that melts the snow in half the time it takes in the earlier months. So it was this year, though snow-wreaths might be seen on the higher grounds in the month of April. Strange to say, April was a better hunting month this year than March. It was wet, and cold, and splashy enough in all conscience.

The season, so prosperous during its continuance, closed, we are happy to say, with fewer drawbacks and derangements to future foxhunting than generally attends the finish of each year. As some advertising tradespeople are always dissolving partnership, or retiring from business to get in their debts, so some few hunts brought their "stock" to market, most likely for the purpose of weeding the studs or of getting parties to "buck up" in the way of subscription. These objects being accomplished, the "firms" resumed business, in some cases, perhaps, with a change 
of "foreman," or cutter-out-we mean, whipper-in. None of the great hunts were affected with the "spring cough," and we trust they are now all about taking the field again with undiminished vigour, and long enduring permanence.

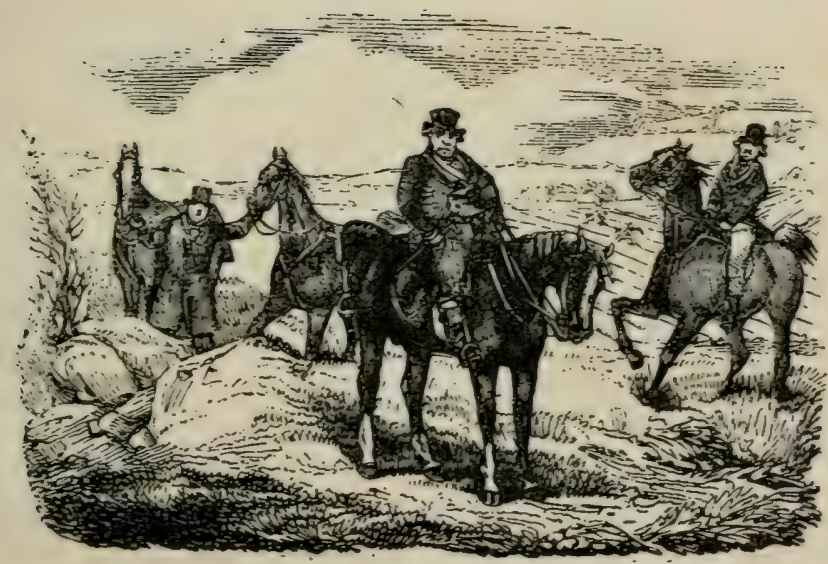


Printed by

Morrison \& Gibb Limited, Edinturgh 

20-1

.

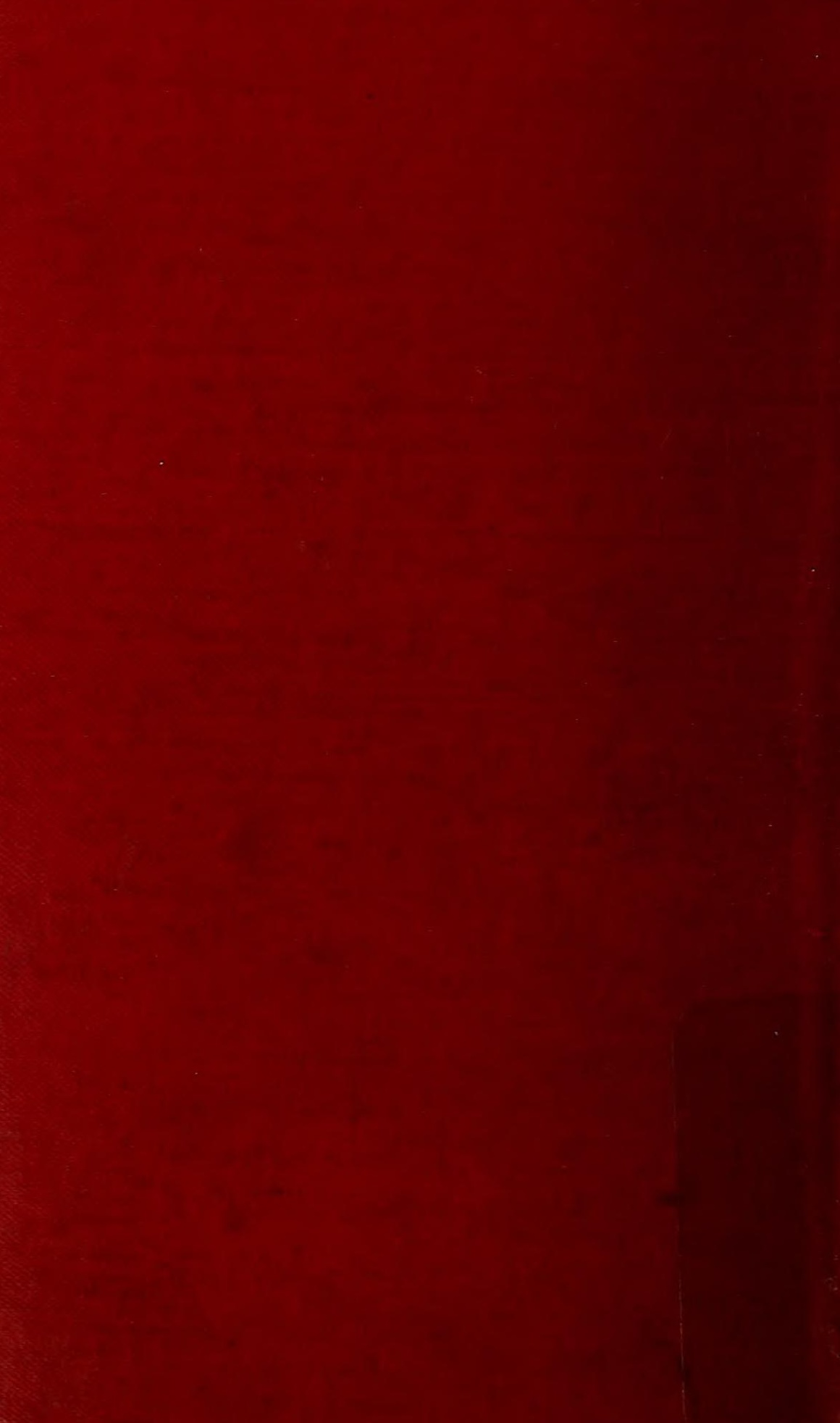

